\title{
Wetland Water Cooling Partnership: The Use of Constructed Wetlands to Enhance Thermoelectric Power Plant Cooling and Mitigate the Demand of Surface Water Use
}

\section{Final Scientific Report}

\author{
Prepared for: \\ U.S. Department of Energy \\ National Energy Technology Laboratory \\ Pittsburgh, PA 15236 \\ DE-NT0006644
}

Prepared by:

Applied Ecological Services, Inc.

17921 Smith Road, PO Box 256

Brodhead, Wisconsin 53520

608.897 .8641

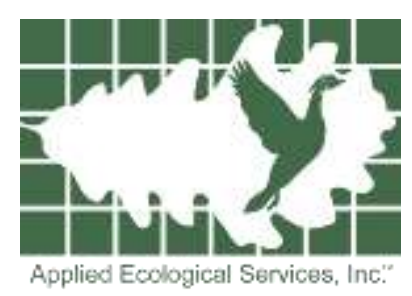

Sterling Energy Services, LLC 2215 Perimeter Park Drive, Suite 8 Atlanta, GA 30341 770.381 .1995

Principal Authors:

Steven I. Apfelbaum, President/Principal Ecologist, AES

Kenneth W. Duvall, Partner, SES

Theresa M. Nelson, PE, AES

Douglas M. Mensing, AES

Harlan H Bengtson, PhD, SES

John Douglas Eppich, PE, PhD, Waterflow Consultants

Clayton Penhallegon, Jr., PE, SES

Ry L. Thompson, AES 


\section{Disclaimer:}

The report was prepared as an account of work sponsored by an agency of the United States Government. Neither the United States Government nor any agency thereof, nor any of their employees, makes any warranty, express or implied, or assumes any legal liability or responsibility for the accuracy, completeness, or usefulness of any information, apparatus, product, or process disclosed, or represents that its use would not infringe privately owned rights. Reference herein to any specific commercial product, process, or service by trade name, trademark, manufacturer, or otherwise does not necessarily constitute or imply its endorsement, recommendation, or favoring by the United States Government or any agency thereof. The views and opinions of authors expressed herein do not necessarily state or reflect those of the United States Government or any agency thereof. 
Abstract:

Through the Phase I study segment of contract \#DE-NT0006644 with the U.S. Department of Energy's National Energy Technology Laboratory, Applied Ecological Services, Inc. and Sterling Energy Services, LLC (the AES/SES Team) explored the use of constructed wetlands to help address stresses on surface water and groundwater resources from thermoelectric power plant cooling and makeup water requirements. The project objectives were crafted to explore and develop implementable water conservation and cooling strategies using constructed wetlands (not existing, naturally occurring wetlands), with the goal of determining if this strategy has the potential to reduce surface water and groundwater withdrawals of thermoelectric power plants throughout the country.

Our team's exploratory work has documented what appears to be a significant and practical potential for augmenting power plant cooling water resources for makeup supply at many, but not all, thermoelectric power plant sites. The intent is to help alleviate stress on existing surface water and groundwater resources through harvesting, storing, polishing and beneficially re-using critical water resources.

Through literature review, development of conceptual created wetland plans, and STELLA-based modeling, the AES/SES team has developed heat and water balances for conventional thermoelectric power plants to evaluate wetland size requirements, water use, and comparative cooling technology costs. The ecological literature on organism tolerances to heated waters was used to understand the range of ecological outcomes achievable in created wetlands. This study suggests that wetlands and water harvesting can provide a practical and cost-effective strategy to augment cooling waters for thermoelectric power plants in many geographic settings of the United States, particularly east of the 100th meridian, and in coastal and riverine locations.

The study concluded that constructed wetlands can have significant positive ancillary socio-economic, ecosystem, and water treatment/polishing benefits when used to complement water resources at thermoelectric power plants.

Through the Phase II pilot study segment of the contract, the project team partnered with Progress Energy Florida (now Duke Energy Florida) to quantify the wetland water cooling benefits at their Hines Energy Complex in Bartow, Florida. The project was designed to test the wetland's ability to cool and cleanse power plant cooling pond water while providing wildlife habitat and water harvesting benefits. Data collected during the monitoring period was used to calibrate a STELLA model developed for the site. It was also used to inform management recommendations for the demonstration site, and to provide guidance on the use of cooling wetlands for other power plants around the country. As a part of the pilot study, Duke Energy is scaling up the demonstration project to a larger, commercial scale wetland instrumented with monitoring equipment. Construction is expected to be finalized in early 2014. 
Table of Contents

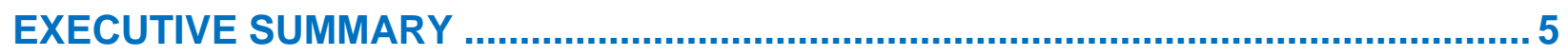

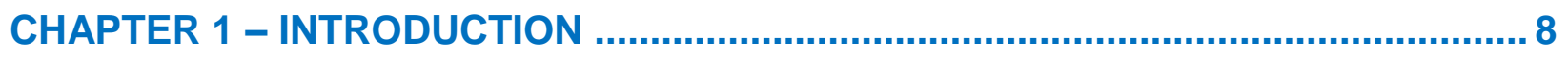

CHAPTER 2 - BACKGROUND ON ISSUES ASSOCIATED WITH WATER USE AND

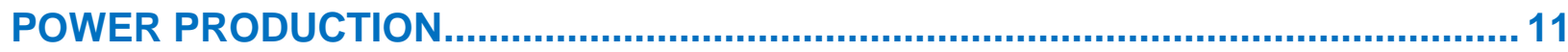

CHAPTER 3 - SCIENCE AND HISTORY OF WETLANDS …..................................... 27

CHAPTER 4 - OPPORTUNITIES AND CHALLENGES ASSOCIATED WITH USING WETLANDS FOR POWER PLANT WATER STORAGE AND / OR COOLING ........... 32

CHAPTER 5 - WETLANDS WATER COOLING - EVALUATION MODEL................... 54

CHAPTER 6 - WETLAND WATER COOLING DEMONSTRATION PROJECT ........... 81

CHAPTER 7 - FINDINGS AND CONCLUSIONS..................................................... 90

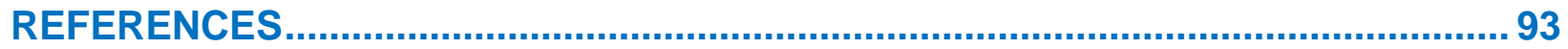

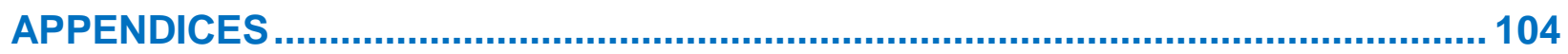




\section{EXECUTIVE SUMMARY}

Applied Ecological Services, Inc. and Sterling Energy Services, LLC (the AES/SES Team) has completed work on contract \#DE-NT0006644 with the U.S. Department of Energy's National Energy Technology Laboratory to explore the use of constructed wetlands to help address stresses on surface water and groundwater resources from thermoelectric power plant cooling and makeup water requirements. The project objectives were crafted to explore and develop implementable water conservation and cooling strategies using constructed wetlands (not existing, naturally occurring wetlands), with the goal of potentially reducing surface water and groundwater withdrawals of thermoelectric power plants throughout the country. Additionally, we recognize the importance of water quality in possible reuse strategies. Thus we have also included some exploration for the use of constructed wetlands for improving water quality and re-use efficiency.

Our evaluation of regional fresh water supply needs in power production started through the review of water resource studies by the U.S. Department of Energy's National Energy Technology Laboratory, the Electric Power Research Institute, and many others. It was clear how water use requirements and the potential benefits of using wetlands would vary by region, site-specific conditions, technology, and competing water demands. Early in our project, some energy industry professionals were skeptical about a role for wetlands to supplement water resources on the scale required for power generation.

Our exploratory work has documented what appears to be a significant and practical potential for augmenting existing power plant water resources with constructed wetlands for cooling water. As we began our evaluation, it became apparent there was a lack of communication between personnel in various disciplines who need to communicate in order to realize what may be considered non-conventional and alternative water supply solutions. As we moved deeper into the project and expanded communications with industry professionals, including power generators and utility industry water resource engineers, we found significant openness and interest in understanding the opportunities available from exploring alternative water sources from constructed wetland strategies, and how they may complement existing systems.

In addition to this report of findings, the project has produced a comprehensive STELLA-based empirical model that supports the feasibility analysis of how constructed wetlands can augment existing water supplies and contribute to cooling waters. The same models can evaluate tradeoffs in water sources with emphasis on availability to meet supply needs, and flexibility provided by constructed wetlands. An initial economic analysis of constructed wetlands versus conventional water cooling strategies is provided and suggests that constructed wetlands are cost competitive with conventional condenser cooling technologies. The analysis also offers complementary advantages in storing and capturing additional waters plus providing habitat, groundwater recharge, 
and a reduced seasonal dependence on stream, lake or groundwater sources of operational water systems.

Through the literature review and research findings, the AES/SES Team concluded the following:

1. It is feasible, practical and economically viable to use constructed wetlands to augment water resources for makeup supply and cooling at many, but not all, thermoelectric power plant sites to help alleviate stress on existing surface water and groundwater resources through harvesting, storing, polishing and beneficially reusing critical water resources.

2. Constructed wetlands can have significant positive ancillary socio-economic and ecosystem benefits when used to complement water resources at thermoelectric power plant sites.

3. The magnitude of impact and overall economics of using constructed wetlands will be highly site-specific, yet the study indicates the strategy can have widescale potential across much of the Eastern United States.

4. The STELLA-based model can be a useful tool in helping to evaluate the required wetland area and ratio of watershed to wetland area for a given water resource objective. The model can assist in projecting performance for a given wetland area and ratio of watershed to wetland, based on power plant heat and water balances and site hydrological and climate data.

5. While not studied as part of this project, a constructed wetland specifically designed to clean and polish plant effluents can serve a useful wastewater treatment/cleansing function, thus providing for possible beneficial re-use at the site.

6. There is a need for near-term additional study. This would include full-scale demonstration projects covering a range of sites and technologies to further document the engineering, water resource and social-economic benefits. This would also benefit from cross-discipline workshops to stimulate the understanding and adoption of wetland-based strategies to enhance existing systems.

Our conclusions are not intended to suggest that a strategy to employ constructed wetlands should, or even could, supplant conventional cooling and makeup water resources, or that a wetland and water harvesting strategy should or could be implemented in all locations. However, we conclude that constructed wetlands should be a mainstream strategy that can produce beneficial outcomes (e.g., regulatory, financial, public relations, additional water quantity and improved quality, and supply assurances when normal supplies are stressed) for power producers, which can mitigate the demand on traditional surface water and groundwater resources from power production.

These benefits are likely achievable throughout much of the eastern US. To illustrate this, we created detailed maps documenting and aligning water availability from watersheds with the water resource needs of power producers throughout the U.S. Realizing the potential of this strategy will require a strategic communication process on 
the technology of wetlands, and what they are and what they are not. Such a process will include workshops on how to plan, evaluate, and deploy wetland water harvesting and constructed wetland technologies for cooling, supply, and cleansing strategies in various regions of the country.

During the implementation phase of the project, the AES/SES Team tested the findings on a pilot scale wetland used for cooling at Hines Energy Complex in Bartow, The project was developed, in partnership with Duke Energy Florida (previously Progress Energy Florida) to demonstrate cooling using constructed wetlands. Though the Hines Energy Complex experiment, we believe cooling wetlands can be one component for reducing surface water and groundwater withdrawals. The pilot scale wetland at Hines Energy Complex was used for monitoring and modeling the cooling benefits observed. The small pilot-scale wetland demonstrated favorable results with cooling water temperature reduction. As a result, Duke Energy and the AES/SES team proceeded with development of a commercial scale, 250-acre wetland (SA-8) for water cooling at the Hines Energy Complex that is anticipated to come online in early 2014. 


\section{CHAPTER 1 - INTRODUCTION}

\section{Project Background and Summary of Findings}

Applied Ecological Services, Inc. (AES) and Sterling Energy Services, LLC (SES) contracted with the U.S. Department of Energy's National Energy Technology Laboratory (USDOE/NETL) to explore the use of constructed wetlands to help alleviate the increasing stress on surface water and groundwater resources from thermoelectric power plant cooling water requirements. The project objective is to determine if there are implementable water conservation and cooling strategies using constructed wetlands to achieve a reduction in ground and surface water withdrawal and to use wetlands to beneficially allow the re-use of water multiple times and reduce the overall consumption of water in power plants.

The project also aims to explore supplementing the benefits of reduced water usage with other added socio-economic and ecological values at thermoelectric power plant sites. Suc benefits would include:

- improving net heat rates for existing power generation units;

- helping reduce or avoid the limitations on electricity production when low surface water flows or excessive heat limit the ability of the unit to operate within permitted levels on the hottest days;

- providing a suite of biological and physical mechanisms to help treat wastewater contaminants;

- reduced impacts to fisheries and other aquatic life forms and their production;

- active and passive recreational opportunities; and improved ecosystem services provided by created wetlands (e.g. such as water quality improvement, flood water storage, plant and wildlife habitat, and enhanced carbon dioxide $\left(\mathrm{CO}_{2}\right)$ sequestration); and

- watershed-scale benefits.

The AES/SES Team of ecologists, water resource engineers, hydrologists, wetland restoration specialists, wildlife and fishery specialists, and mechanical and civil engineers has used a straightforward methodology for this project involving the following steps:

1) We reviewed scientific and non-scientific sources of wetland and watershed ecological literature and publications.

2) We reviewed the power production process literature for operating and engineering issues associated with conventional thermoelectric power plant cooling systems and associated economics.

3) We reviewed industry water resource issues, statistics on cooling cycles and types of systems, power plant water chemistry for influent and effluent requirements, environmental regulations and water resource issues and 
concerns, and relevant fossil fueled and nuclear power plant siting and expansion plans and system related economics.

4) We studied the literature on constructed wetlands, including potential biological impacts that would occur when wetlands are used in conjunction with power plant cooling cycles.

5) We implemented a small-scale pilot experiment to monitor wetland water cooling benefits at a power plant in Florida.

The basic, conventional once-through (open) and closed loop (closed) cooling system designs for Rankine cycle based thermoelectric power plants (utilized by some $90 \%$ of the thermoelectric power plants in the United States) have changed very little in the past half century (water cycle balances for open and closed loop systems are shown in the Appendix-Chapter 1). We learned of many innovations and improvements made in modifying the specific designs and pumping technologies for natural draft and mechanical draft systems, as well as various methods of air and water flow to enhance the overall cooling system efficiency, but the basic design to remove the required BTU's of heat from the unit condenser has remained essentially unchanged in many decades.

The Team's objective was to explore the usefulness of utilizing constructed wetlands to harvest, supplement, complement, or even in some cases, cleanse and allow for re-use of existing water supplies in existing power production systems. In some cases, it may even be possible to replace conventional systems, using the same underlying methodology in use today, by employing constructed wetlands to complement traditional cooling ponds in lieu of mechanical systems. In essence, this strategy could supply an alternative (or additional) source of cooling water to the condenser to remove the same amount of heat, and/or for makeup water to the power plant systems, thus lessening the impact on regional surface water and potentially groundwater systems.

This study did not seek to improve or modify conventional cooling system technologies. Instead, we have considered how it may be possible to tie alternative water resources into existing plant systems, thus lessening the stress on regional water resources. We have concluded this is relatively straightforward, with no insurmountable challenges identified. In fact, because, many power plants already utilize a combination of cooling ponds and/or open and closed cooling systems around wells, rivers, reservoirs and other systems, we have found no issues that would prevent combining alternative systems, including required filtering, pumping, storage and interconnection of various systems, as is done today at many sites.

This study concludes that there are implementable water conservation and cooling strategies using created wetlands which can have a positive impact on both withdrawal and consumption of water in many power plants. The following chapters summarize our Team's findings and conclusions. The report establishes the basic foundation along with our analysis and develops some fundamental strategies which may be implemented at existing and planned power plants. Additionally, the report includes discussion regarding the STELLA model developed to assist in the evaluation of 


\section{Chapter 1}

wetland resources at power plants, as well as screening criteria. Findings are presented in the following chapters along with supporting documentation.

As a result of the research and modeling results, the project progressed into the implementation phase of using constructed wetlands. Phase II involved modifying and instrumenting a small constructed wetland at Hines Energy Complex in Bartow, Florida to monitor and model cooling water temperature reductions. The pilot-scale wetland determined that water conservation and cooling strategies using constructed wetlands is achievable. However, to understand full-scale cooling capacity the project is being expanded into a larger constructed wetland adjacent to the pilot-scale site to understand the benefits of cooling on a commercial scale. The cooling water temperature reduction data collected in the pilot-scale wetland is significant enough to suggest this type of system used at other facilities across the country would allow the re-use of water multiple times therefore reducing the overall consumption of water by power plants. 


\section{CHAPTER 2 - BACKGROUND ON ISSUES ASSOCIATED WITH WATER USE AND POWER PRODUCTION}

\section{Water Use and Supply Challenges}

As this report will be reviewed by individuals from many disciplines who may not always be familiar with issues outside their discipline, we have included summary background information developed over the past decade by NETL and others regarding water use and supply challenges as they relate to thermoelectric power plants. Additionally, we have included details of conventional power plant cooling technologies and water balances, along with background discussion on the history and technology of wetlands. This is to provide a comprehensive understanding and framework of the issues, technologies, challenges and possible non-conventional solutions available for individuals from diverse fields to consider.

To accomplish this study, the Team first completed a comprehensive literature review of studies, scientific and non-scientific articles, and related publications. The literature review included studies regarding the issues and regulatory requirements, as well as documentation on the conventional technologies employed throughout the industry in thermoelectric cooling cycles today, as well as plans for non-conventional technologies under consideration for future application.

Historically, the U.S. has been fortunate to have an abundance of fresh water to meet growing demands for this resource (e.g., thermoelectric cooling, agricultural irrigation, industrial processes, municipal water/wastewater management, human consumption, etc.). More recently, multiple studies have documented that our existing water supplies will not be able to meet the continued demand for the diminishing fresh water supply. Some power companies and other industries are considering a range of technological cooling innovation that are very expensive compared to the conventional water cooling systems (this is partly because we have really never paid the true cost of water but instead only paid for the reimbursement costs for the pipes and other infrastructure to transport water) in how we utilize water in energy production.

In recent years, studies by the USDOE/NETL, EPRI and various scientific agencies have all documented that water and power production issues are inextricably linked, with approximately $40 \%$ of all freshwater withdrawal in the U.S. being utilized to meet thermoelectric power plant cooling requirements (Bistline, 2008; DOE/NETL, 2006; USGS, 2004).

Thermoelectric power plant cooling in the U.S. requires more freshwater withdrawal than any other activity except irrigation. While a majority of the water withdrawn during once-through power plant cooling is returned, a significant volume is still consumed in the power production process through evaporation into the atmosphere, thus removing 
a large volume from the regional watershed and ecosystem. With energy demand increasing, and the impact of competing human freshwater requirements growing, NETL has recognized that it is essential to find more effective methods of enhancing traditional water supplies (with non-traditional supplies) and/or materially reduce the demand (gallons/MWh) from traditional power plant cooling and makeup cycles using surface water sources for thermoelectric power plant operating cycles (Figure 1).
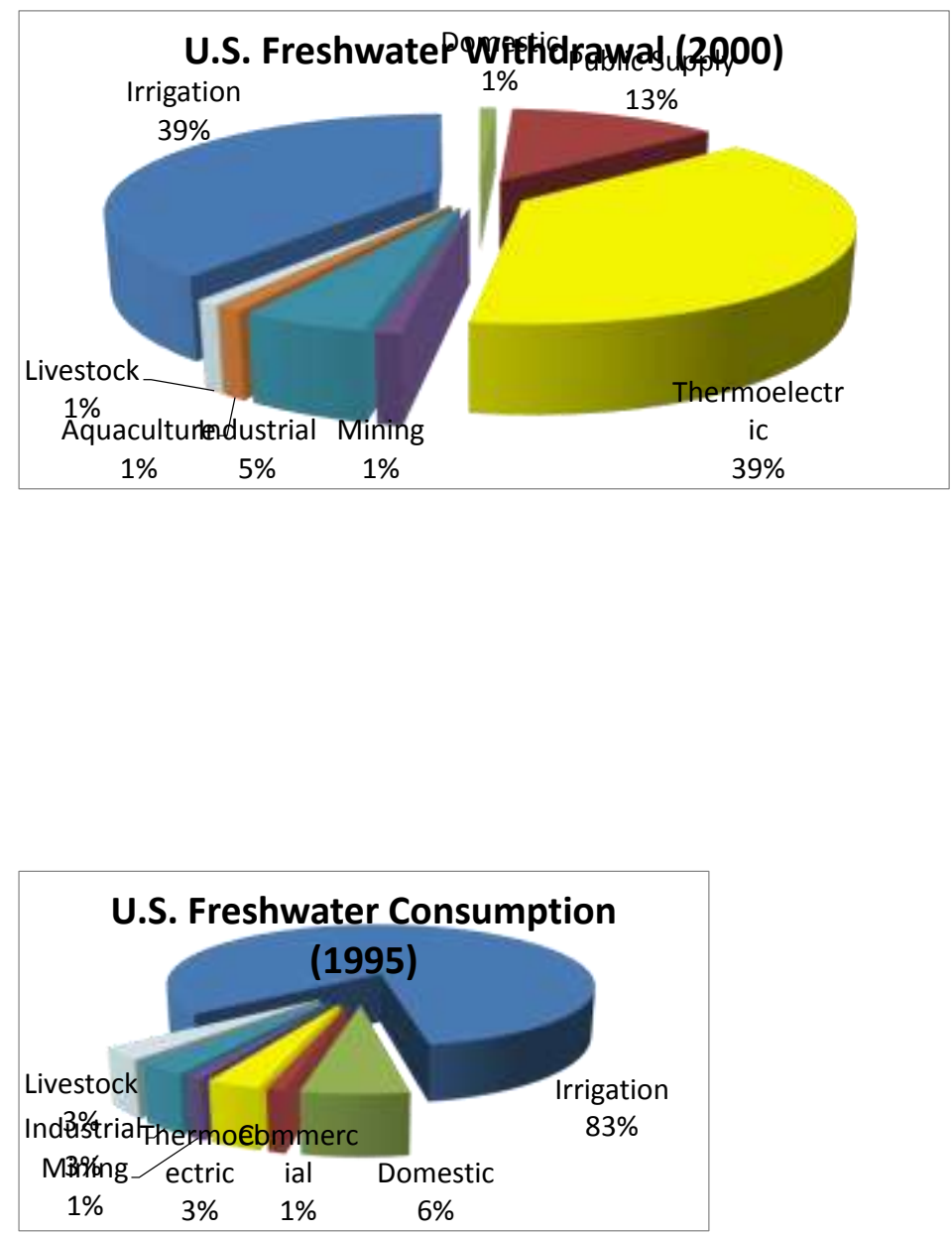

Source: DOE/NETL, 2006; USGS, 2004; USGS 1998

Figure 1. U.S. Freshwater Withdrawal and Consumption. 
It is now widely recognized that the continued use of surface water for power plant cycles at this tremendous rate is not sustainable, given the increasing stress levels on our nation's natural resources, water systems, and ecosystems from population growth, increasing industrial and agricultural use, and widening drought and climate change conditions. This is emphasized in recent government reports. As stated in a Government Accounting Office report to Congress (GAO, 2003):

"National water availability and use has not been comprehensively assessed in 25 years, but current trends indicate that demands on the nation's supplies are growing. In particular, the nation's capacity for storing surface water is limited and groundwater is being depleted. At the same time, growing population and pressures to keep water instream for fisheries and the environment place new demands on the freshwater supply. The potential effects of climate change also create uncertainty about future water availability and use."

A similar concern is expressed by the Department of Energy/Natural Energy Technology Lab (DOE/NETL 2006), with emphasis on water needs for thermoelectric power plants, as follows:

"Growing concerns about freshwater availability must be reconciled with growing demand for power if the United States is to maintain economic growth and current standards of living. Thermoelectric generating capacity is expected to increase by nearly 22\% between 2005 and 2030, based on the Energy Information Administration's (EIA) Annual Energy Outlook 2006 (AEO 2006) projections."

The growing conflict and competition between the multiple, increasing uses of our limited fresh water supplies and the concurrent expansion of our electrical production system (that will continue to accelerate in the future) necessitates the implementation of innovative and sustainable water management solutions.

\section{Background on Wet Cooling Systems for Thermoelectric Power Plants}

The fundamental purpose for the cooling system in any Rankine cycle, steam driven power plant is to condense the low pressure steam output from the turbine. This is necessary so that the condensed, liquid water can be pumped into the boiler to generate high pressure steam to drive the turbine and spin the generator. Water withdrawal and water consumptions rates for thermoelectric power generation are dependent upon the type of cooling system used to condense the steam. Most steam turbine power plants currently in operation use either once-through cooling systems or closed-cycle cooling systems that utilize cooling towers. Once-through cooling and closed-cycle cooling tower systems have high water withdrawal and/or water consumption rates, and thus are candidates for possible application of constructed wetlands for enhancing water management. 
Once-through cooling systems simply withdraw water from a river, lake or reservoir, use it as the coolant in the condenser, and return water that is $\sim 20^{\circ} \mathrm{F}$ higher in temperature to the receiving water as shown in Figure 2. Once-through cooling is used in most thermoelectric power plants built before 1970 and it is still used in almost half of United States thermoelectric generating capacity (Bistline, 2008). Closed-cycle, wet cooling systems use cooling towers to cool the heated water leaving the condenser by evaporating a portion of the water, as shown in Figure 2. Closed-cycle wet cooling systems are used in most of the thermoelectric power plants built since 1970 in the United States (Bistline, 2008).

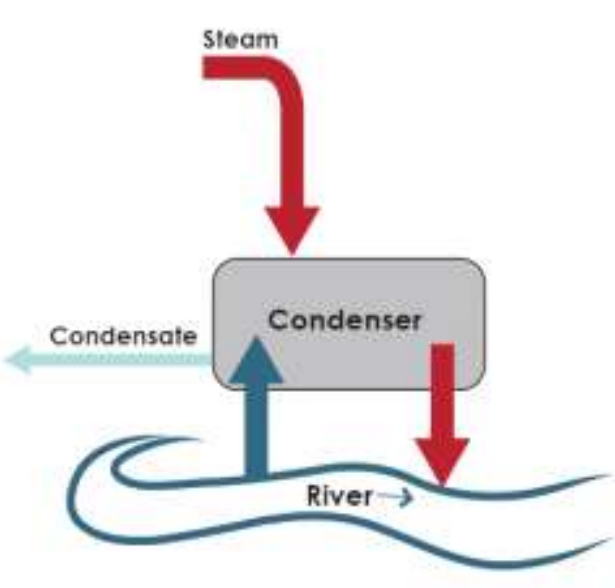

ONCE-THROUGH COOLING SYSTEM

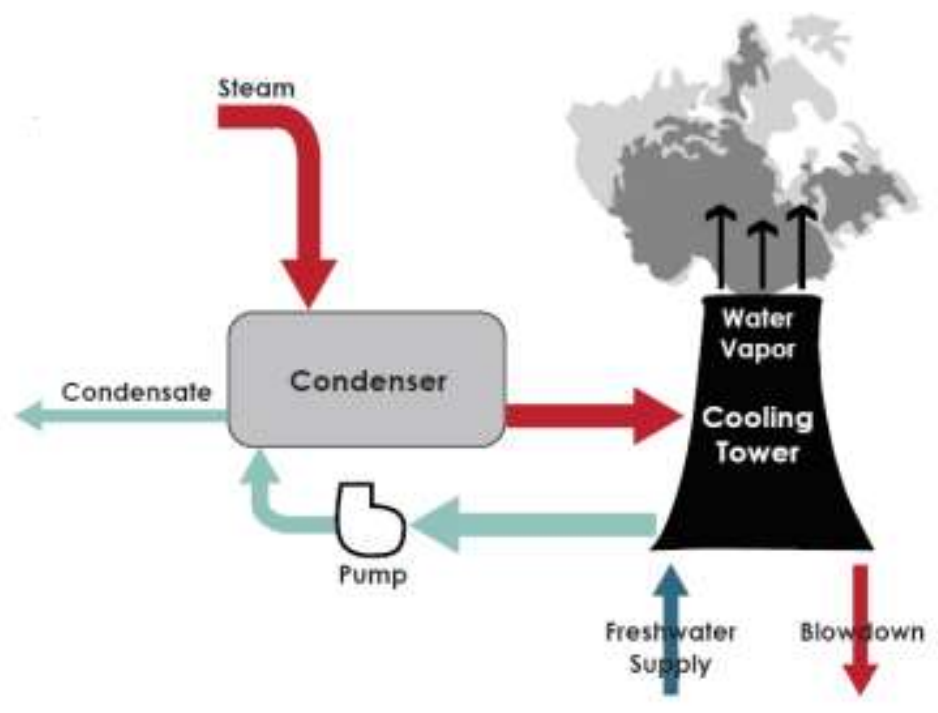

CLOSED-CYCLE COOLING SYSTEM

Source: DOE, 2006

Figure 2. Once-through and Closed-cycle Cooling Systems.

Primarily in Western U.S. regions where water resources are scarce, some newer power plants use a dry cooling or hybrid cooling system, but capital costs and operating costs are higher for these systems than for either once-through or closed-cycle wet cooling. Maulbetsch (2005) presented a comparison of costs, heat rate penalties, and cooling system power requirements for once-through cooling, wet tower cooling and dry cooling; his findings are summarized in Table 1.

Table 1. Comparison of Cooling System Effects on Cost of Electricity.

\begin{tabular}{|l|c|c|c|}
\hline \multirow{2}{*}{$\begin{array}{c}\text { Items for Comparison } \\
\text { (for 500 MW Steam Plant) }\end{array}$} & \multicolumn{3}{|c|}{ Type of Cooling System } \\
\cline { 2 - 4 } & Once-Through & Wet Tower & Dry Cooling \\
\hline Capital Cost & base & base $+0.4 \%$ & base $+12.5 \%$ \\
\hline Cooling System Power & base & base $+2.5 \mathrm{MW}$ & base $+3.0 \mathrm{MW}$ \\
\hline Plant Heat Rate & base & base $+0.4 \%$ & base $+4.0 \%$ \\
\hline Power Production Cost & base & base $+1.9 \%$ & base $+4.9 \%$ \\
\hline
\end{tabular}

Source: Maulbetsch, 2005 
Percentages of generating capacity by generation type and cooling system type are shown in Table 2.

Table 2. Generating Capacity by Generation Type and Cooling System Type.

\begin{tabular}{|l|c|c|c|c|}
\hline \multirow{2}{*}{ Generation Type } & \multicolumn{4}{|c|}{ Percentage (\%) } \\
\cline { 2 - 5 } & Wet Recirculating & Once-Through & Dry & Cooling Pond \\
\hline Coal & $48.0 \%$ & $39.1 \%$ & $0.2 \%$ & $12.7 \%$ \\
\hline Fossil Non-Coal & $23.8 \%$ & $59.2 \%$ & $0.0 \%$ & $17.1 \%$ \\
\hline Combined Cycle & $30.8 \%$ & $8.6 \%$ & $59.0 \%$ & $1.7 \%$ \\
\hline Nuclear & $43.6 \%$ & $38.1 \%$ & $0.0 \%$ & $18.3 \%$ \\
\hline Total & $41.9 \%$ & $42.7 \%$ & $0.9 \%$ & $14.5 \%$ \\
\hline
\end{tabular}

Source: DOE/NETL, 2008, based on data from EIA Form 767, years 2000 and 2005.

The distribution of U.S. thermoelectric power plant cooling systems, by cooling system type and water source (fresh or saline water), are shown in Figure 3.

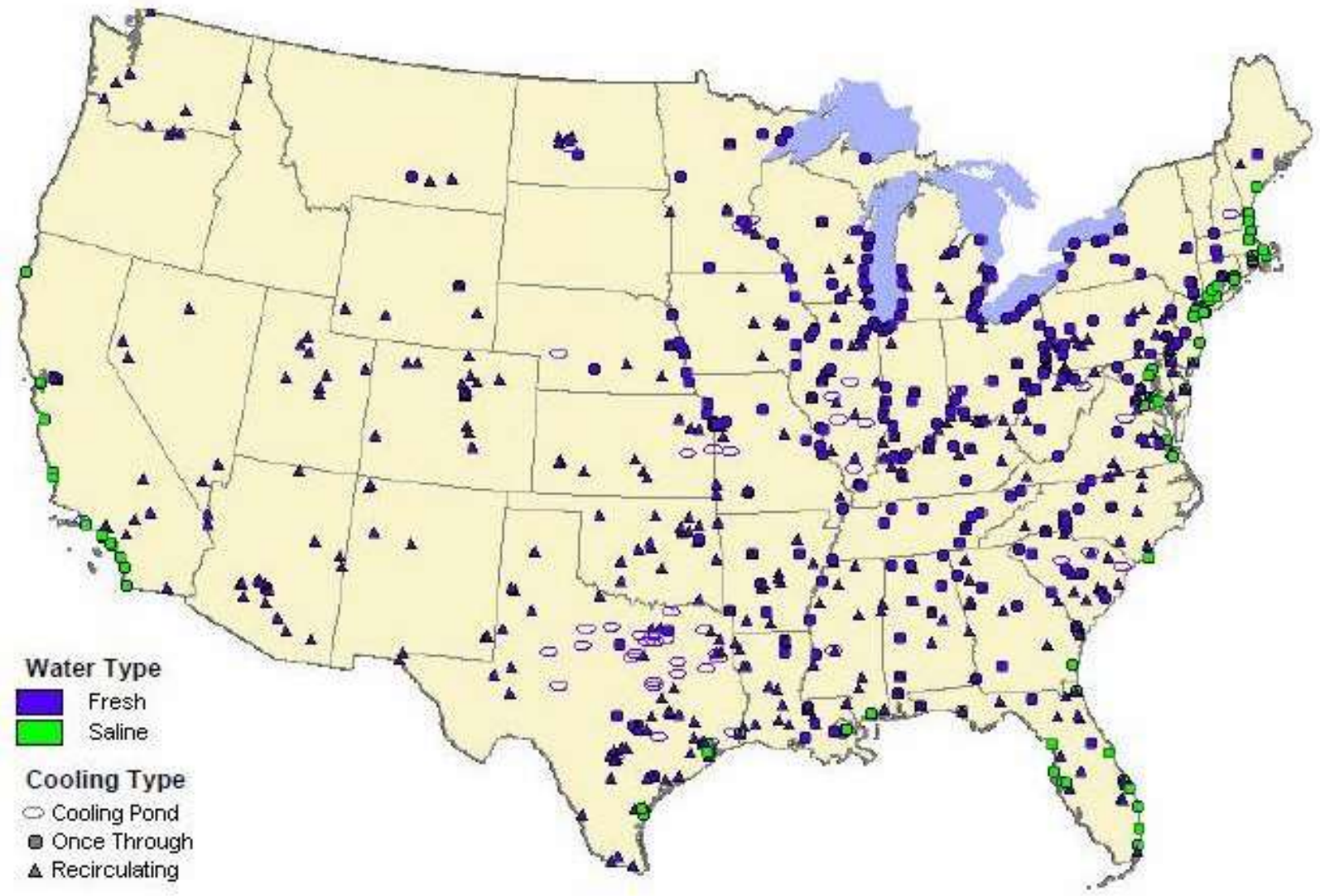

Source: DOE/NETL (2008), based on data from EIA Form 767, years 2000 and 2005.

Figure 3. Thermoelectric Power Plant Cooling Systems by Type and Water Source. 
Typical cooling water withdrawal and consumption rates in gal/MWh for several combinations of plant and cooling system types are presented in Table 3.

Table 3. Cooling Water Withdrawal and Consumption (Evaporation to the Atmosphere) for Common Thermal Power Plant and Cooling System Types.

\begin{tabular}{|l|c|c|}
\hline \multicolumn{1}{|c|}{ Plant and Cooling System Type } & $\begin{array}{c}\text { Water } \\
\text { Withdrawal } \\
\text { (gal/MWh) }\end{array}$ & $\begin{array}{c}\text { Typical Water } \\
\text { Consumption } \\
\text { (gal/MWh) }\end{array}$ \\
\hline Fossil/biomass/waste-fueled steam, once-through cooling & 20,000 to 50,000 & $\sim 300$ \\
\hline Fossil/biomass/waste-fueled steam, pond cooling & 300 to 600 & $300-480$ \\
\hline Fossil/biomass/waste-fueled steam, cooling towers & 500 to 600 & $\sim 480$ \\
\hline Nuclear steam, once-through cooling & 25,000 to 60,000 & $\sim 400$ \\
\hline Nuclear steam, pond cooling & 500 to 1,100 & $400-720$ \\
\hline Nuclear steam, cooling towers & 800 to 1,100 & $\sim 720$ \\
\hline
\end{tabular}

Source: EPRI, 2002.

Visual representation of typical water withdrawal and consumption rates for oncethrough cooling, cooling towers, and pond cooling is given in Figures 4 through 6.

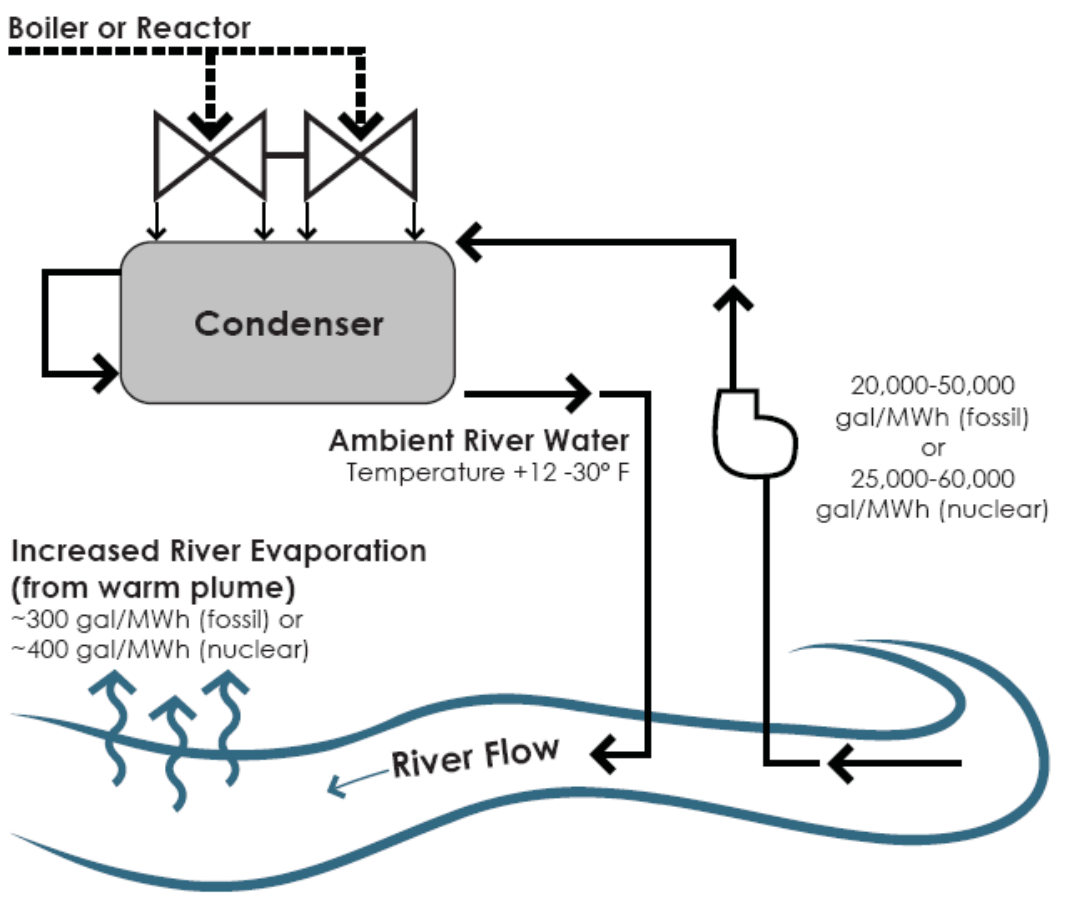

*High flow value corresponds to low $\Delta T$ value, and vice versa

Source: EPRI, 2002.

Figure 4. Water Withdrawal and Evaporation Rates in Steam Power Plants with Once-Through Cooling. 


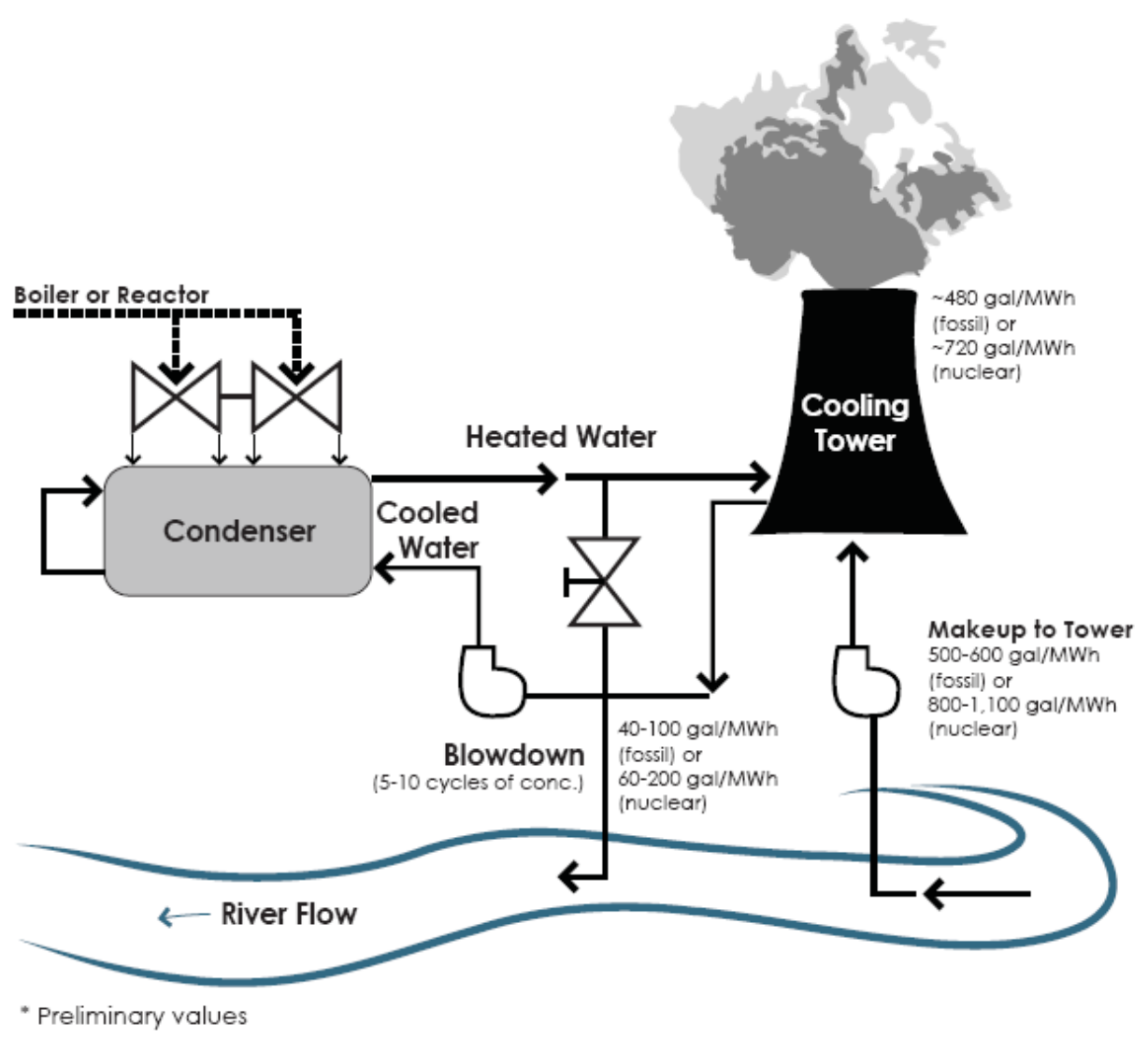

Source: EPRI, 2002.

Figure 5. Water Withdrawal and Evaporation Rates in Steam Power Plants with Cooling Towers. 


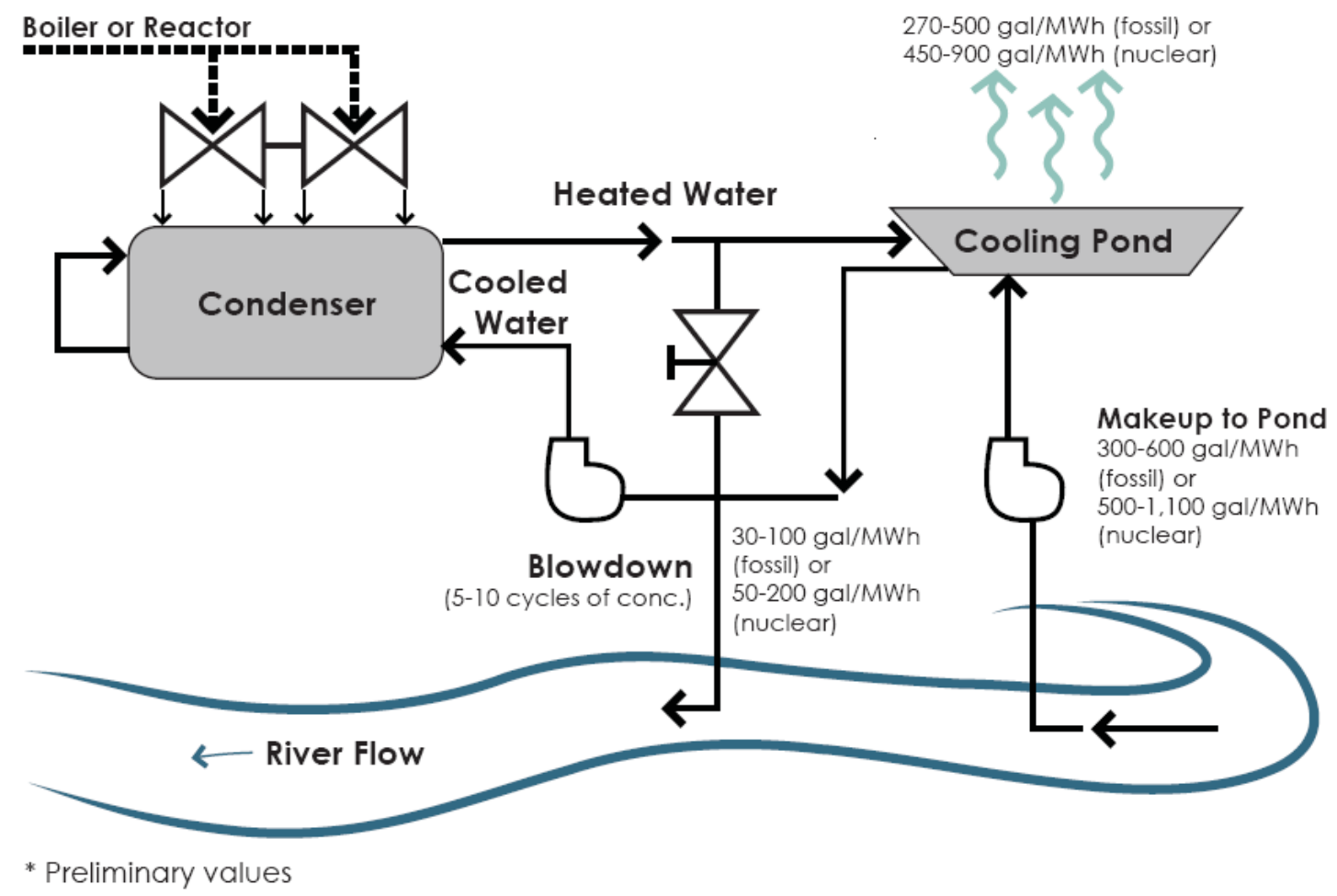

Source: EPRI, 2002.

Figure 6. Water Withdrawal and Evaporation Rates in Steam Power Plants with Cooling Ponds.

\section{Background on Current Cooling Pond Use in Power Plants}

Cooling ponds are used at $10-15 \%$ of fossil fuel fired steam power plants in the United States, with the majority located in the eastern two thirds of the U.S. (Figure 3 ). The most complete source of annual statistical information available about U.S. power plants in general, and their cooling systems in particular, is the U.S. Department of Energy, Energy Information Agency, Form EIA-767 (USDOE/EIA, 2005). EIA changed some of their data collection procedures in 2006, so 2005 is the last year for which Form EIA767 data, the source for much of the information in this section, is available. As there have been few power plants constructed since 2005, this information should be current.

\section{U. S. Fossil Fuel Power Plants with Cooling Ponds in 2005}

There are similarities and relationships which can be drawn from the long-term use of cooling ponds and the use of constructed wetlands to enhance water management. Thus, we reviewed the data available on cooling pond use in U.S thermoelectric power plants.

Based on the 2005 EIA Form-767 data, there were 111 fossil fuel steam power plants in the U.S. that had one or more cooling ponds providing at least part of their cooling system. Those 111 plants had 168 pond cooling systems, because some of the plants 
had more than one cooling system. A list of those 111 utilities/plants with pond cooling systems, including city and state for the utility and city and state for the plant, is provided in the Appendices. These utilities/plants are arranged according to the type of cooling system respective utilities identified for their plant on Form-767. Following is a summary of the self-identified types of cooling systems for the utilities/plants in the list.

- 'Once-through with cooling pond(s) or canal(s)' - 37 plants

- 'Re-circulating with cooling pond(s) or canal(s)' -46 plants

- 'Once-through with cooling pond(s) or canal(s)' and either 'once-through with fresh water' or 'once-through with saline water' - 7 plants

- 'Re-circulating with cooling pond(s) or canal(s)' and 're-circulating with fresh water' - 5 plants

- Other cooling system type or types (all included a cooling pond) -16 plants

\section{Types of Cooling Pond Systems}

As shown in the list above, most of the cooling pond systems are identified as either 'once-through with cooling pond' or 're-circulating with cooling pond.' A typical flow pattern for a once-through cooling pond system is shown in Figure 7. This type of cooling system would eliminate or reduce any thermal effect on the cooling water source/receiving water body, one of the issues of concern for power plants with oncethrough cooling. It may not, however, have a significant effect on the withdrawal rate from the cooling water source/receiving water body, which is a primary issue with oncethrough cooling systems because of potential effects on fish and other aquatic life. If the site hydrology is favorable, the evaporation from the cooling pond may be balanced by precipitation and collected stormwater runoff conveyed into the cooling pond, resulting in minimal net consumption of water. This, of course, is highly site specific. Data indicates that some plants currently utilize once-through ponds primarily to augment conventional cooling systems to provide supplemental cooling as required prior to discharge back to the source water body. 


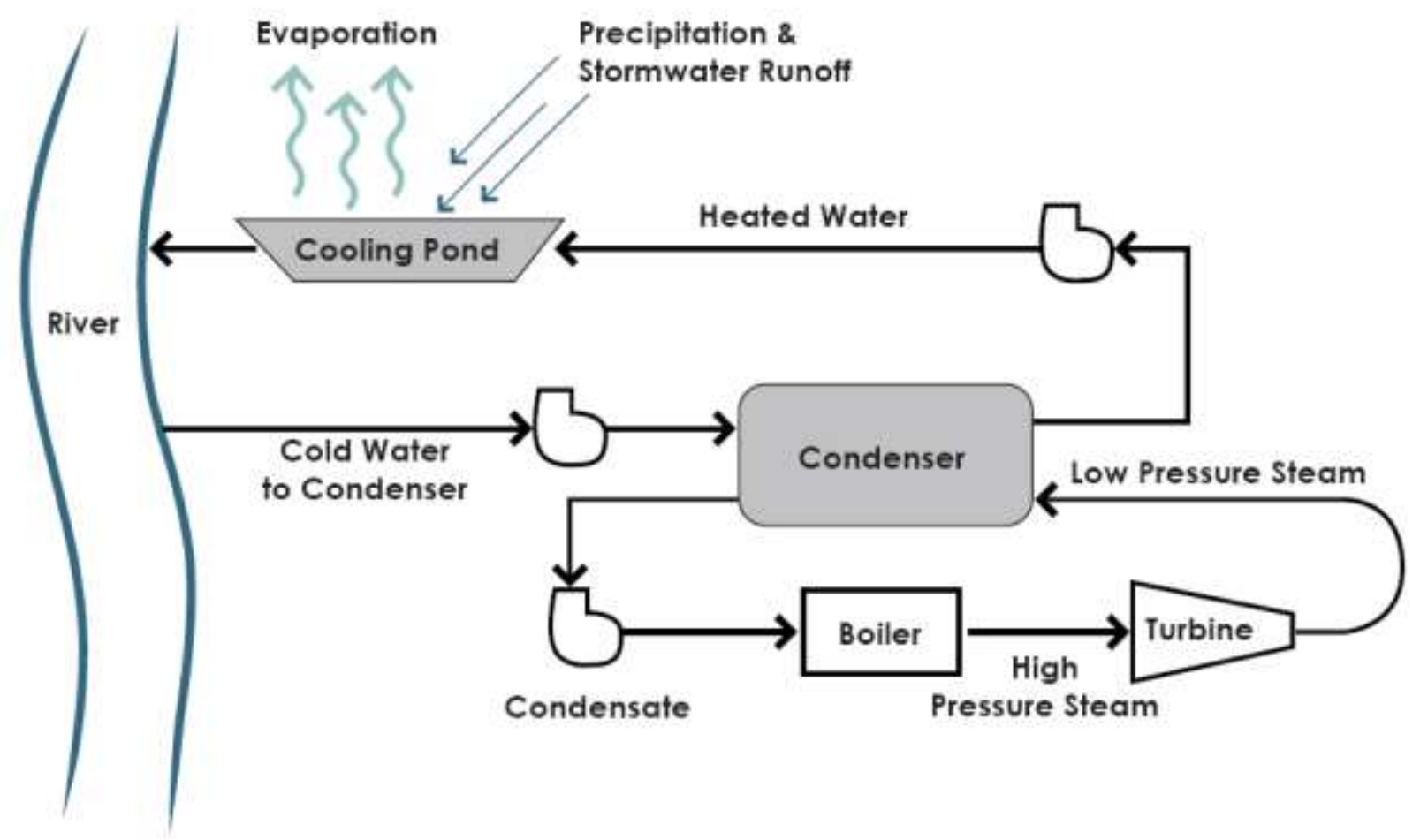

Figure 7. Typical Once-through Cooling Pond System Flow Pattern.

A typical flow pattern for a re-circulating cooling pond system is shown in Figure 8 . This type of system will minimize thermal effects on the source/receiving water body, and will reduce the withdrawal rate from the source body of water to the net rate of consumption, typically much less than the once-through withdrawal rate. Here also, favorable site hydrology could lead to balancing the rate of evaporation from the cooling pond with input from precipitation and stormwater runoff. With an adequate watershed feeding to the pond, this type of system may be a closed system with no withdrawal from or discharge to the associated watershed, river, lake or reservoir. 


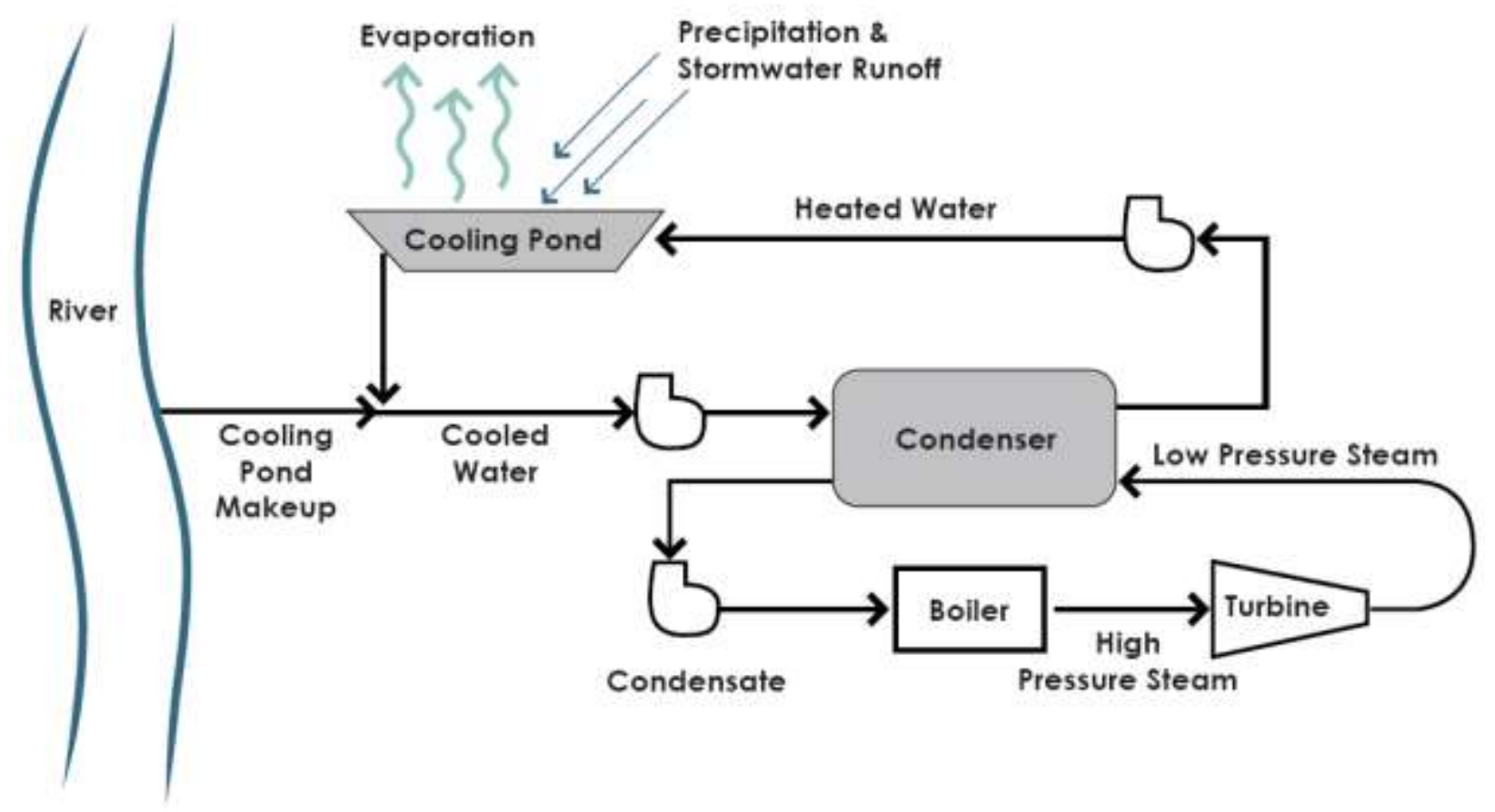

Figure 8. Typical Re-circulating Cooling Pond System Flow Pattern.

\section{Cost of Cooling Pond Cooling Systems}

Based on information from DOE/EIA Form EIA-767 (DOE/NETL, 2009), wet recirculating (wet cooling tower) systems are reported to be approximately $30-40 \%$ more expensive than once-through systems. Dry cooling systems can be 3 to 4 times more expensive than a wet re-circulating system, and cooling pond cost is approximately the same as that for a wet re-circulating system. Cost information developed by DOE/NETL is shown in Figure 9 along with information about the number of each type of cooling system built before and after 1970 . 


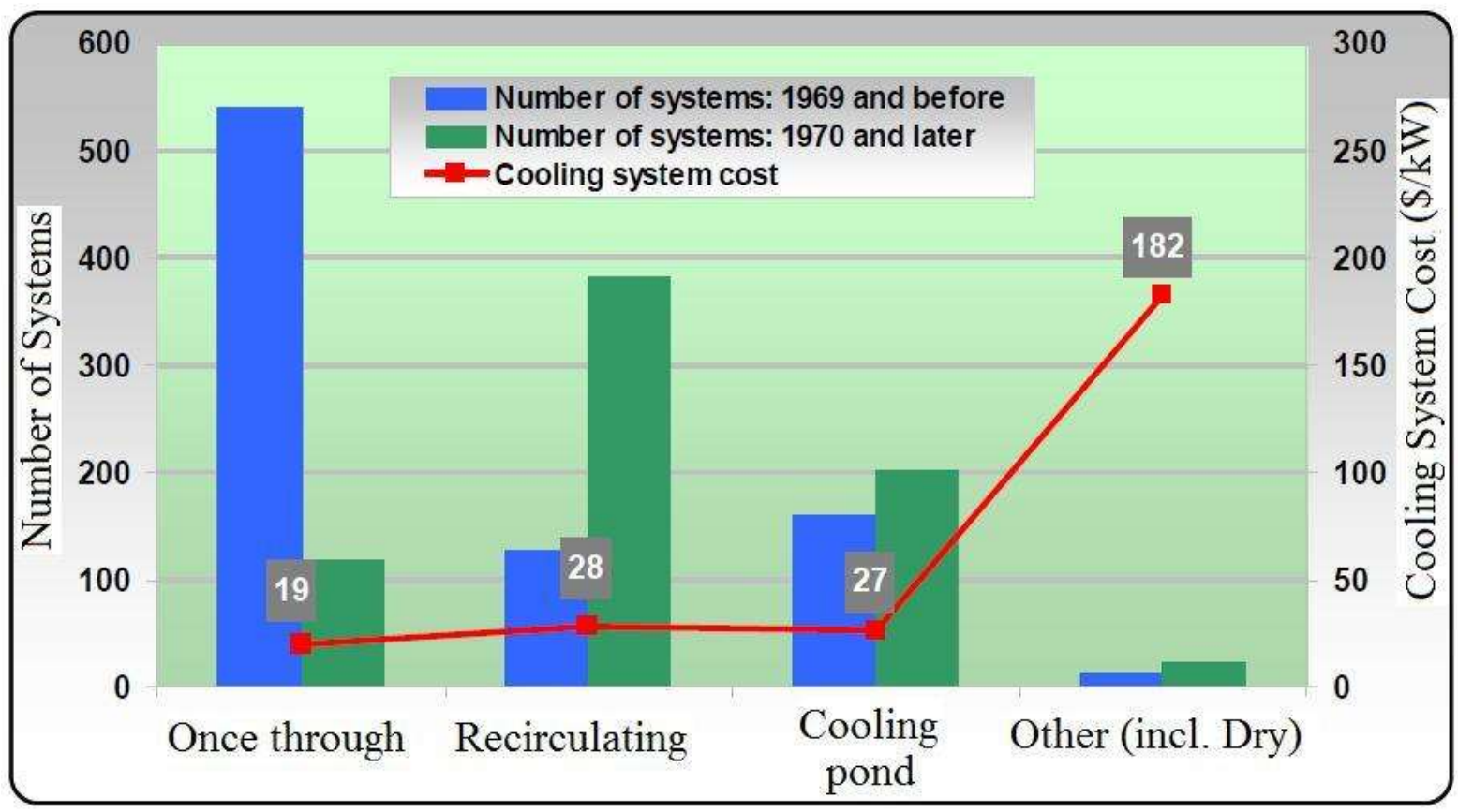

Source: DOE/NETL, 2009.

Figure 9. Number and Cost of Thermoelectric Plant Cooling Systems by Type.

\section{Cooling Pond Cooling System Characteristics}

Table 4 provides a summary of average, maximum, and minimum values for several cooling pond parameters. The table is arranged by cooling system type with the majority of the entries in the first two categories, once-through with cooling pond(s) or canal(s) and re-circulating with cooling pond(s) or canal(s). 
Table 4. Summary of Cooling Pond Parameters.

Plants with Once Throuah Cooling with Cooling Pond(s) or Canal(s) (53 entries) Plants with Once Through Cooling with Cooling Pond(s) or Canal(s) ( 53 entries)

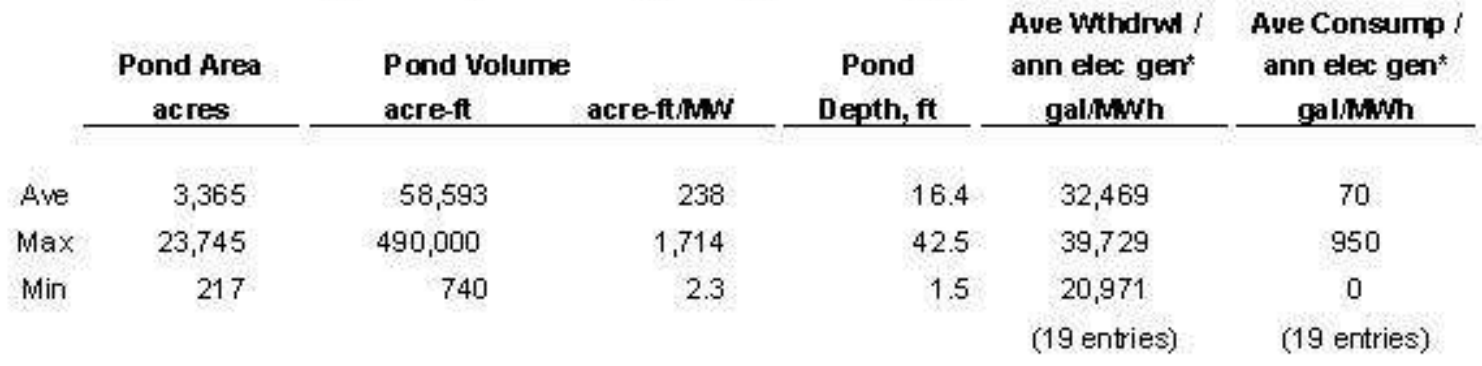

Plants with Recirculating Cooling with Cooling Pond(s) or Canal(s) (76 entries)

\begin{tabular}{|c|c|c|c|c|c|c|}
\hline & $\begin{array}{c}\text { Pond Area } \\
\text { acres }\end{array}$ & $\begin{array}{l}\text { Pond Volume } \\
\text { acre-ft }\end{array}$ & acre-ftinty & $\begin{array}{c}\text { Pond } \\
\text { Depth, ft }\end{array}$ & $\begin{array}{c}\text { Ave Whthdrwi } / \\
\text { ann elex gent } \\
\text { galiswih }\end{array}$ & $\begin{array}{c}\text { Aue Consump } \\
\text { ann elec gen } \\
\text { galinwhy }\end{array}$ \\
\hline Ave & 1,642 & 25,512 & 68 & 14.4 & 21,029 & 4,489 \\
\hline $\operatorname{Max}$ & 6,600 & 150,000 & 540 & 34.5 & 86,316 & 72,562 \\
\hline Min & 21 & 126 & 1.1 & 3.0 & $\begin{array}{c}217 \\
\text { (39 entries) }\end{array}$ & $\begin{array}{c}0 \\
\text { (39 entries) }\end{array}$ \\
\hline
\end{tabular}

Plantswith once Ibrough wCoolinaPond(s) or Canal(s) + once Through wFresh or Salt water ( 9 entries)

\begin{tabular}{|c|c|c|c|c|c|c|}
\hline & $\begin{array}{c}\text { Pond Area } \\
\text { acres }\end{array}$ & $\begin{array}{l}\text { Pond Volume } \\
\text { acre-ft }\end{array}$ & acre-ft/muy & $\begin{array}{c}\text { Pond } \\
\text { Depth, ft }\end{array}$ & $\begin{array}{l}\text { Ave Withdrwi / } \\
\text { ann elec gent } \\
\text { galihwh }\end{array}$ & $\begin{array}{c}\text { Ave Consump } \\
\text { ann elec gen* } \\
\text { galminh/ }\end{array}$ \\
\hline Ave & 673 & 7,910 & 22 & 5.9 & 145,837 & 1,557 \\
\hline $\operatorname{Max}$ & 3,500 & 62,800 & 111 & 18 & 520,102 & 14,837 \\
\hline Min & 2.7 & 8.0 & 0.07 & 2.7 & 737 & 0 \\
\hline
\end{tabular}

Plants with Other Cooling System Types or Combinations ( 30 entries)

\begin{tabular}{|c|c|c|c|c|c|c|}
\hline & $\begin{array}{c}\text { Pond Area } \\
\text { acres }\end{array}$ & $\begin{array}{l}\text { Pond Volume } \\
\text { acre-ft }\end{array}$ & acre-fthw & $\begin{array}{c}\text { Pond } \\
\text { Depth, ft }\end{array}$ & $\begin{array}{l}\text { Ave Whthdwi / } \\
\text { ann elec gent } \\
\text { galimwh }\end{array}$ & $\begin{array}{c}\text { Aue Consump } \\
\text { ann elec gen* } \\
\text { galihwh }\end{array}$ \\
\hline Ave & 800 & 14,041 & 32 & 14 & 71,608 & 5,095 \\
\hline $\max$ & 3,750 & 77,000 & 187 & 30 & 509,046 & 47,804 \\
\hline Min & 2.0 & 27 & 0.012 & 6.4 & 208 & 0 \\
\hline
\end{tabular}

* Only cooling systems with data for cooling water withdrawal and consumption rates, and annual electrical generation at more than $39 \%$ of full capacity were used for calculating these two parameters.

Source: U.S. Department of Energy, Energy Information Administration (EIA), Form EIA-767: Annual Steam-Electric Plant Operation and Design Data. 2005 data.

http://www.eia.doe.gov/cneaf/electricity/page/eia767.html. 
As would be expected, the data shows there is a large range in the size of the cooling ponds. The surface area varies from a low of 2 acres to a high of 23,745 acres. The pond volume ranges from 8 to 490,000 acre-ft and the pond depth varies from 1.5 to $42.5 \mathrm{ft}$.

Several derived cooling pond parameters were calculated and are included in the table: pond volume/generator nameplate rating (acre-ft/MW), average cooling water withdrawal/annual electrical generation (gal/MWh), and average cooling water consumption/annual electrical generation (gal/MWh).

The pond volume divided by generator nameplate rating in acre-ft/MW ranges from very small to very large values, likely because some are very small or are providing only part of the cooling load for a given generator. The data available does not provide the necessary information to distinguish between pond size and cooling percentages or effectiveness.

Overall, the values for average cooling water withdrawal and consumption rates divided by annual electrical generation varied significantly; however, for two data subsets (the first two sets of data in Table 4) there was a great deal of consistency for these two parameters. Again, the data available is not sufficient to develop more specific conclusions than summarized herein.

\section{Plants Having Once-through Cooling with Cooling Pond(s) or Canal(s)}

The first set of data in Table 4 contains average, maximum and minimum values of the withdrawal and consumption parameters in the last two columns for 19 plants with 'once-through cooling with cooling pond(s) or canal(s)'. The other 34 plants with 'oncethrough cooling with cooling pond(s) or canal(s)', were not used for these calculations because they were missing data for average annual cooling water withdrawal, discharge, and/or consumption rates, or else their annual electrical generation was less than $40 \%$ of full capacity. The values for average annual cooling water withdrawal (in gal/MWh) for these 19 plants all fall within the 20,000 to 50,000 gal/MWh range reported by EPRI (2002) for power plants with once-through cooling. All but three of these 19 plants report zero consumption.

A reasonable interpretation of this data is that these 19 plants all have a flow pattern like that shown in Figure 7 above, and that they are reporting rate of withdrawal from the source water body and rate of discharge to the cooling pond. The data do not appear to provide any information about the net withdrawal from the source water body.

\section{Plants Having Re-circulating Cooling with Cooling Pond(s) or Canal(s)}

The second set of data in Table 4 contains average, maximum and minimum values of the withdrawal and consumption parameters in the last two columns for 39 plants with 're-circulating cooling with cooling pond(s) or canal(s)'. The other 37 plants with 'recirculating cooling with cooling pond(s) or canal(s)', were not used for these 
calculations, because they were missing data for average annual cooling water withdrawal, discharge, and/or consumption rates, or else their annual electrical generation was less than $40 \%$ of full capacity. The values for average annual cooling water withdrawal (in gal/MWh) for these 39 plants fall into two categories.

Data from 17 of the plants is very similar to that for the 19 plants discussed above in the 'once-through cooling with cooling pond(s) or canal(s)' category. That is, they all report consumption rate as zero or very low, so their discharge rate equals (or approximately equals) their withdrawal rate. The withdrawal rate in gal/MWh covers a wider range for these 17 plants than for the 19 once-through plants. The reported withdrawal rates for these 17 plants range from 27,524 to $86,310 \mathrm{gal} / \mathrm{MWh}$.

Data from a majority of the other 22 plants in this 39 plant data set have a different, but relatively consistent, pattern. All but 3 of these 22 plants report zero discharge, with their consumption rate thus equaling their withdrawal rate. The reported withdrawal/consumption rate for these 22 plants ranges from 217 to $72,562 \mathrm{gal} / \mathrm{MWh}$. The 3 remaining plants reported fairly low withdrawal rates $(1,122$ to $2,879 \mathrm{gal} / \mathrm{MWh})$ and discharge rates equal to half the withdrawal rate or less.

A reasonable interpretation of this data is that the 17 plants whose data is similar to that from the 19 plants above (that reported 'once-through with cooling pond(s) or canal(s)' as their cooling system) probably have a flow pattern shown in Figure 7. Likewise, the 22 plants that report zero or nearly zero discharge probably have a flow pattern shown in Figure 8, which has no discharge from the cooling pond to the source water body, and requires withdrawal from the source water body equal to the difference between the evaporation rate from the cooling pond and the input rate to the cooling pond from precipitation and storm water runoff. The precipitation and storm water runoff rate could vary a great deal from site to site, hence the wide variation in cooling water consumption rates.

\section{Summary}

These data from power plants using cooling ponds document that, in selected regions of the U.S., it has already been demonstrated possible to design power plant cooling systems utilizing cooling ponds capable of operating as a closed or nearly closed loop system with minimal withdrawal or consumption of water from regional water sources. Interpretation of the data also highlights the capacity and capability of existing cooling pond designs vary greatly, as does their ability to capture (harvest) and retain as much precipitation and watershed runoff as possible in order to minimize water requirements from a traditional river, lake or reservoir sources. This is an important finding in that the use of constructed wetlands to harvest, store/retain, polish water, and even recharge aquifers is only a small design step from what is being accomplished at some power plant sites with cooling ponds today.

We have viewed aerial photographs of many power plants with cooling ponds and find many have adjacent lands that appear to be viable for expanded harvesting and water 
storage. Constructed wetlands could complement both cooling and makeup at these sites, where the existing ponds are open and not able to contribute their maximum potential for minimizing demand upon regional surface water sources. Additionally, the industry's experience with shallow ponds provides relevant data for use in the scope and design of complementary constructed wetland systems at sites with and without existing ponds. 


\section{CHAPTER 3 - SCIENCE AND HISTORY OF WETLANDS}

\section{Wetland Overview}

Wetlands are areas where the frequent and/or prolonged presence of water at or near the soil surface drives the development of soil and the composition of vegetation and wildlife communities. Section 404 of the U.S. Clean Water Act (USEPA 1972) defines wetlands as follows:

"Wetlands are areas that are inundated or saturated by surface water or groundwater at a frequency and duration sufficient to support, and that under normal circumstances do support, a prevalence of vegetation typically adapted for life in saturated soil conditions. Wetlands generally include swamps, marshes, bogs, and similar areas."

To be considered a jurisdictional and regulated "wetland," an area must contain the following three criteria: 1) wetland hydrology, 2) wetland (or "hydric") soils, and 3) wetland (or "hydrophytic") vegetation. Definitions of these criteria as well as field indicators are provided in the U.S. Army Corps of Engineers 1987 Wetland Delineation Manual and Regional Supplements (USACE 1987 and 2010).

There are many types of wetlands and several classification schemes (e.g., Anderson, Cowardin, et al. 1979; Shaw and Fredine 1956 Circular 39). The major types of natural wetlands in the U.S. include marsh (non-tidal and tidal), swamp (forested, shrub), bog (northern, pocosins), and fen. Constructed wetlands are wetlands that have been either created or restored, usually to provide some sort of ecosystem service (e.g., water quality improvement) or habitat benefits and outcomes.

The major water sources that form and support wetlands are precipitation, seepage (groundwater to surface water discharge), and connections to water level changes, such as during flooding in nearby or connected surface waters (e.g., oceans, lakes, ponds, rivers, streams, etc) and the direct capture and storage of runoff from the contributing watersheds. While many wetlands are frequently or permanently inundated, many wetlands have a more variable hydrologic regime, including regular dry periods (e.g., vernal pools, playas and prairie potholes). Wetland soils may consist of mineral soil (e.g., loam) or organic soil (e.g., peats and mucks). Vegetation varies widely across different wetland types, but wetlands are some of the most biologically productive natural ecosystems in the world in terms of productivity and biodiversity. Many wildlife species depend on wetlands for all or portions of their life cycle.

\section{Wetland Functions, Values and Ecosystem Services}

Wetland functions are defined as a natural process or a series of natural processes that occur within a wetland and continue regardless of their perceived value to humans. Functions result from both the living and non-living components of a specific wetland, 
and can often be quantified objectively. Wetland functions can be divided into several broad, arbitrary groups, such as hydrologic, biologic, habitat, water quality, nutrient and carbon cycling, and geologic.

Wetland values are the estimates of the importance or worth of wetland functions and physical characteristics associated with the wetland. Wetland values include providing opportunities for recreation, such as hunting, fishing, bird watching, wildlife watching, photography, boating, and hiking. Other values associated with wetlands include education, research, tourism, aesthetics, heritage, food, and uniqueness. The value of wetlands (a combination of ecological, societal and economic values) is often difficult to quantify. With the advance of scientific disciplines, many wetland functions have become more recognized as values (e.g., carbon sequestration). Often these concepts of functions and values overlap, hence the emergence of the term ecosystem services.

Ecosystem services (which encompasses both functions and values) can be categorized as: 1) provisioning services (e.g., food, clean water, raw materials), 2) regulating services (e.g., carbon sequestration, climate regulation, waste decomposition, purification of water and air, flood control), 3) supporting services (e.g., primary production, nutrient dispersal and cycling, crop pollination), and 4) cultural services (e.g., recreational experiences, inspiration, scientific discovery). These services can be measured at various scales of time (e.g., short-term and long-term) and space (e.g., internally, locally, regionally, at the watershed scale and even globally).

Ecosystem services specific to wetlands include harboring immensely productive plant and animal communities, containing nearly one-fourth of global terrestrial carbon, and it has been documented that a very large percentage of the endangered and threatened plant and animal species on Earth require wetlands during their life cycle. It is also important to note that the ecosystem services provided by a particular wetland are dependent on many factors, including climatic conditions, location within the watershed, quantity and quality of receiving waters, surrounding ecosystem disturbances (both natural and anthropogenic), and local and regional human activities (e.g., development, commercial fishing).

Wetlands around the world are used for production of human food (e.g., fish, plants, and waterfowl), are used for potable water supplies, provide flood storage and flood damage reduction, among many other uses. In some locations, wetlands are also used for human habitation (e.g., The Marsh Arabs in Iraq, etc). In industrialized nations, wetlands are also used for recreation - boating, fishing, bird watching, and many other uses. Wetlands are one of the primary outlets for bird watching in the U.S., which has become one of the largest single recreational pursuits that generates revenues in excess of $\$ 12$ billion dollars annually (www.audubon.org). Bird watching revenues have actually exceeded the revenues from hunting, and this change in the value of wetlands is part of the reason why there is increasing public resistance to wetland destruction, increased wetland protection regulations, and more and more fervent public outcry about water and power production uses. 
Wetlands provide an important hydrologic flux and flood storage service. Wetlands act as natural sponges, storing water during rain events and slowly releasing the water into associated surface waters, groundwater, and the atmosphere. Water's momentum is slowed as it passes through wetlands, reducing the erosion potential, reducing the flood peak height, and allowing for groundwater recharge, all of which can increase base flow in nearby surface water features, especially during dry periods. Groundwater recharge of up to $20 \%$ of wetland volume per season has been documented (Weller 1981). Wetland types differ in their ability to store water based on a variety of physical and biological factors, including landscape position, soil saturation, and organic soil makeup/degree of decomposition, vegetation density, and type of vegetation. The ability of wetlands to store floodwaters is an ecosystem service that reduces the risk of costly property damages and loss of life. Wetlands located along shorelines and stream/river banks help protect soils from the erosive forces of waves and currents. Wetland plants act as a buffer to attenuate wave energy and sheer stress, and they provide a stabilizing root matrix that helps bind the soil in place. Wetlands provide all of these hydrologic services, which have a significant economic value to society.

Wetlands also perform an important water filtration/water quality service by trapping suspended solids (sediments and organic matter) and by retaining and/or transforming excess nutrients and other pollutants, such as heavy metals. Suspended solid and organic matter filtration by wetlands (often removing $80-90 \%$ of sediment) prevents a source of turbidity from entering downstream waters (Johnston, 1991; Gilliam, 1994). Wetland biogeochemical cycling provides for the removal of nutrients such as nitrogen and phosphorus, providing improved drinking water and reductions in environmental problems such as elevated Biological Oxygen Demand (BOD), algal blooms, dead zones, and fish kills (all associated with excess nutrients). Estimations on nitrogen removal rates by wetlands range between $70-90 \%$ as a result of biological and chemical nitrification / denitrification processes in the nitrogen cycle (Gilliam, 1994). Phosphorus removal by wetlands is variable but can be significant, and heavy metal removal rates range from $20-100 \%$ depending on the metal and the individual wetland (Osmond et al., 1995; Taylor et al., 1990). BOD reduction rates may approach $100 \%$ in wetlands (Hemond and Benoit, 1988).

These water quality services are especially important when the wetland is connected to groundwater or surface waters used for drinking water, swimming, and fishing, as well as, industrial uses. Wetland plants and microorganisms absorb excess nutrients and pathogens from agricultural field runoff, leaking septic fields, and municipal sewage. Pathogens attach to suspended solids that become trapped by the wetland vegetation; the pathogens often die by remaining outside their host organism, direct sunlight, low $\mathrm{pH}$, protozoa consumption, or from toxins excreted by the roots of some wetland plants.

These are just some of the many important ecosystem services provided by wetlands. These services are furnished to varying degrees by different types of natural wetlands, and they can also be optimized through well-designed constructed wetland systems. 


\section{A Brief History of Wetlands}

Wetland degradation and losses have been dramatic throughout much of the world, including the U.S. According to the information in USGS Water Supply Paper 2425 (Dahl \& Allord, 1996), over 50\% of the 221 million acres of wetlands in the U.S. in the 1600 's had been lost to agricultural and land development conversions by the 1980's, leaving about 103 million acres of wetlands in the U.S. at that time. Most of the U.S.'s remaining wetlands have been degraded through partial drainage, nutrient enrichment and other pollution, vegetation alteration, and/or invasive plant species. These lost and degraded wetlands used to help manage precipitation and runoff by holding it in surficial depressions and promoting infiltration and evapotranspiration. Infiltration would feed water into shallow aquifers, and some percentage reached underlying deep aquifers. Shallow infiltration would then re-appear as a base flow into regional streams, rivers, lakes, and other wetlands, providing a relatively stable and consistent source of water.

Today, most developed and agricultural watersheds export water quickly, treating it essentially as a waste product. The hydrologic goal of residential, commercial and industrial properties is generally to remove the water as efficiently as possible, and many agricultural lands have been plumbed with below ground tiles and surface water drainage ditches to both drain historic wetlands as well as maintain arable agricultural soils. These artificial collection, conveyance, and drainage systems deplete surface water and groundwater stocks, often reducing or eliminating the maintenance of surface water features (including wetlands) and groundwater recharge. Loss of wetlands increases the rate and severity of flooding and leads to an increase in nutrient and pollutant loading of nearby water bodies. Many wildlife species and plants that are dependent on wetlands for all or portions of their life cycle are imperiled as wetland acreage is lost through filling or excavation, or as the wetland quality is degraded. Land use alteration and artificial drainage represents the primary contributor to drought in some portions of the U.S., with increasing economic, ecological and cultural impacts. These changes have drastically altered the landscape, including upland as well as aquatic ecosystems and the entire hydrologic cycle, with repercussions for sources of power plant cooling waters.

On a global scale, loss of wetlands is believed to be a contributing factor to global climate change (through lost carbon sequestration capacity and direct release of carbon, methane and nitrous oxides as carbon-rich peats and muck soils decompose under drained urban and agricultural land-uses in former wetland landscapes). Many scientists consider the removal of carbon dioxide from the atmosphere and sequestering it into plant matter which accumulates (buried as peat and soil organic matter) as an increasingly valuable global function of wetlands. Wetland loss has been linked to air quality declines. The decreases in many migratory bird species that depend on wetlands, including waterfowl and shorebirds among many other groups, has been well documented as more of their historic wetland habitat areas have been converted to agricultural croplands or urban settings and uses (fws.gov). 
Constructed wetlands have been designed to mimic some of the functions of natural wetlands, usually focusing on improved water quality through treatment of point and nonpoint sources of water pollution (e.g., stormwater runoff, domestic wastewater, agricultural wastewater, and mine drainage). Constructed wetlands are also used to provide cost-effective alternatives to industrial treatment plants to cleanse and treat petroleum refinery wastes, compost and landfill leachates, fish pond discharges, and pretreated industrial wastewaters, such as those from pulp and paper mills, textile mills, and seafood processing. And even for the power industry, small pilot-scale created wetlands have been used to cleanse sanitary water and other sources of water for reuse in power plant cooling operations (Rodgers and Castle, 2008). In addition, constructed wetlands have been designed to retain/detain stormwater runoff to reduce occurrences of downstream flooding. In most constructed wetland designs, the full range of ecological and societal functions will not occur when compared with natural and constructed wetlands. For instance, a constructed wetland designed to treat stormwater runoff may not be allowed to provide an infiltration/recharge function due to concern over contaminating groundwater. 


\section{CHAPTER 4 - OPPORTUNITIES AND CHALLENGES ASSOCIATED WITH USING WETLANDS FOR POWER PLANT WATER STORAGE AND / OR COOLING}

\section{Open Water Systems vs. Wetlands}

Lakes, ponds, and reservoirs (herein referred to as "open water systems") have long been used for cooling heated effluent from power plants and other industrial facilities, as described in Chapter 2. These open water systems can provide cost-effective and space-effective cooling services, but their ancillary functions and values are often limited. Wetlands can also be designed and managed to provide effective cooling and polishing services, while at the same time providing other socio-economic and environmental benefits.

Wetlands differ from open water "cooling water pond" systems in many important aspects. While open water systems provide some of the same functions and values as wetlands (discussed previously in Chapter 3 of this report), open water systems are typically deeper than wetlands ( $>6$ feet) and they are less productive (i.e., they produce less vegetation and wildlife quantity and do not support the diversity of species found in wetlands). Another difference is that open water systems often experience less hydrologic variation than wetlands; while water levels may vary several feet in open water systems, the ecosystem typically remains inundated and deep (unlike many wetlands, which experience seasonal draw-down or actual dry periods).

The most significant difference between the drawn down water levels in ponds and natural wetlands is the timing of the draw-down. Large ponds and reservoirs do not predictably draw down except during droughty years, while healthy natural wetlands often draw down annually. And the timing of a drought-induced draw-down is also different. In natural wetlands the draw-down occurs in early to mid summer which provides ample time for plants and other life forms to colonize and become productive. In large reservoirs and ponds the draw-down is usually as a result of and after or during the later phases of a drought. At this time it is often far too late during the growing season for plants and other life to respond and use productively the water that remains.

Reservoirs are artificial open water systems constructed for water supply and/or flood storage. These systems may experience substantial water level variation, and subsequently they may possess degraded shoreline vegetation and other diminished functions and values. While open water systems capture sediments and some nutrients, they are often more noticeably degraded by these pollutants and less effective at removing and/or assimilating pollutants when compared with wetlands. Once degradation of an open water system occurs, it is difficult to ameliorate or reverse the effects. 
Because wetlands are able to cool thermal discharges (via evaporation, as in ponds) as well as provide other beneficial services, this study indicates their use at power generation facilities holds much promise while concurrently providing socio-economic and other environmental benefits.

\section{Opportunities}

Table $C$ in the Chapter 4 Appendix, shows a value matrix for several existing power plant water streams, illustrating potential constructed wetland functional role(s), potential stress(es) to the constructed wetland, and potential operational benefit(s) to the power generator through the use of constructed wetlands.

\section{Application of Constructed Wetlands for Cooling and Storage}

From the research, documentation, engineering analysis and discussions with power generators completed to date, the application or integration of constructed wetlands into an overall thermoelectric water cycle is relatively straightforward. As noted in Chapter 2 , the underlying principals of utilizing water to cool steam cycles and provide makeup for power plants is nothing new. Also, as of 2005 , some $12.7 \%$ of thermoelectric plants used cooling reservoirs at the plant site for their primary cooling water source (USDOE/NETL, 2008), while many others use a combination of reservoirs/ponds in conjunction with rivers, streams and lakes. While this is not a new strategy, there is limited experience with the technology of wetlands and what is possible through constructed wetlands specifically designed to augment a power producer's existing water resources.

When one considers the use of constructed wetlands to complement or supplement a thermoelectric water / steam cycle, the wetland really serves the same functions as any reservoir - that is serving as a source for storing, mixing, cooling, polishing and in general supplying water to the power plant systems. Therefore, the use of constructed wetlands in conjunction with power plant water cycles is very similar to the use of reservoirs and ponds, which have been commonly integrated with power plant designs for decades. The differences are also many.

For example, in addition to evaporative cooling, constructed wetlands can be designed to have a subsurface flow capacity which may provide additional cooling capacity. Cooling system performance is essential to the efficiency of plant operations. There is a direct correlation between cooling water (ability to remove heat from the condenser) and unit performance, as shown in Figure $\mathrm{C}$ of the Chapter 4 Appendix. Thus, any supplemental cooling which can be provided during peak periods, when cooling systems are at their design limits, will have a beneficial impact on production. Additionally, the value of efficiency improvements is greatest when power systems are peaking, which is generally when plant cooling systems are most limited.

In some wetland types, underlying gravels and sand (even silt and clay) become saturated as water from the adjoining uplands infiltrates and run in the direction of the 
lower topographic positions on the land which tend to be wetland and drainageways. This subsurface flow through sand and gravel (even through bedrock and subsoil systems) cools the waters before they enter wetlands or go deeper into underlying strata. This also contributes to fundamental changes in the chemistry of the precipitation that fell upon the land from a typical circumneutral and mineral poor state to either a higher or lower $\mathrm{pH}$, and having a mineral richness reflecting the chemistry of the underlying geological and subsoil. In some very heavy lower permeability clay soils, a lesser percentage of subsurface flow along with surface water runoff are typical sources of wetland water sources.

\section{Geographic Analysis of Opportunities for Cooling and Storage}

The modeling results have suggested that the greatest opportunity for utilizing wetlands as part of water storage and cooling operations will be in areas where there is stormwater runoff that could be captured and beneficially reused. Excessive stormwater can be devastating to stream systems and human communities by (1) causing dramatic fluctuations in water level that contribute to instream erosion, and (2) causing flooding for communities adjacent to streams. Therefore capturing this water that would otherwise be a hazard or nuisance, reusing it, and releasing it more slowly to streams would provide benefits to the power plant as well as benefits to the instream ecology and fisheries, and downstream communities.

Evaporation from wetland systems can be substantial, particularly in drier climates. It is expected that where potential evapotranspiration is greater than rainfall, it will be difficult to sustain a wetland systems unless very large watersheds can be intercepted, probably either by locating the wetland in a floodplain, less preferentially by damming a stream. Since damming streams is very undesirable from an ecological perspective and from a water rights perspective in the western states, the most beneficial projects would likely be located where, at a minimum, average annual precipitation exceeds the average annual potential evapotranspiration (PET) and where wetlands historically occurred that can be restored, using constructed wetlands in their historic settings of soil and landscape and watershed position.

Figure 10 on the next page provides a clear depiction of regions of the US that would be most suitable for incorporating wetlands into cooling strategies based on these climate considerations. Green and blue areas have greater precipitation than PET. This figure also shows existing power plant surface water withdrawals. Those power plants with significant water withdrawal in the green and blue areas of the map may be good candidates for further exploration of feasibility of incorporating wetlands into their power plant water storage, cooling, and/or treatment strategies.

As mentioned above, capturing and holding stormwater runoff for reuse turns excessive runoff water that can contribute to problems, into water that is beneficial. Therefore, it is also helpful to review watershed runoff across the country as a potential screening tool for determining where wetland construction for power plant operations may be beneficial. In areas with very little runoff, larger watersheds would be necessary to 
sustain a wetland, as described above. Figure 11 presents isopleths of annual runoff depth across the country. This map is consistent with Figure 10 in suggesting that the eastern half of the country and the northwest coastal areas will be most promising. Figure 11 also includes data on power plant water withdrawals, both for individual facilities and as total withdrawal amounts by county. Similar to Figure 10, this overlay can be used to match areas of highest water use with areas with greatest opportunity for stormwater capture and beneficial reuse.

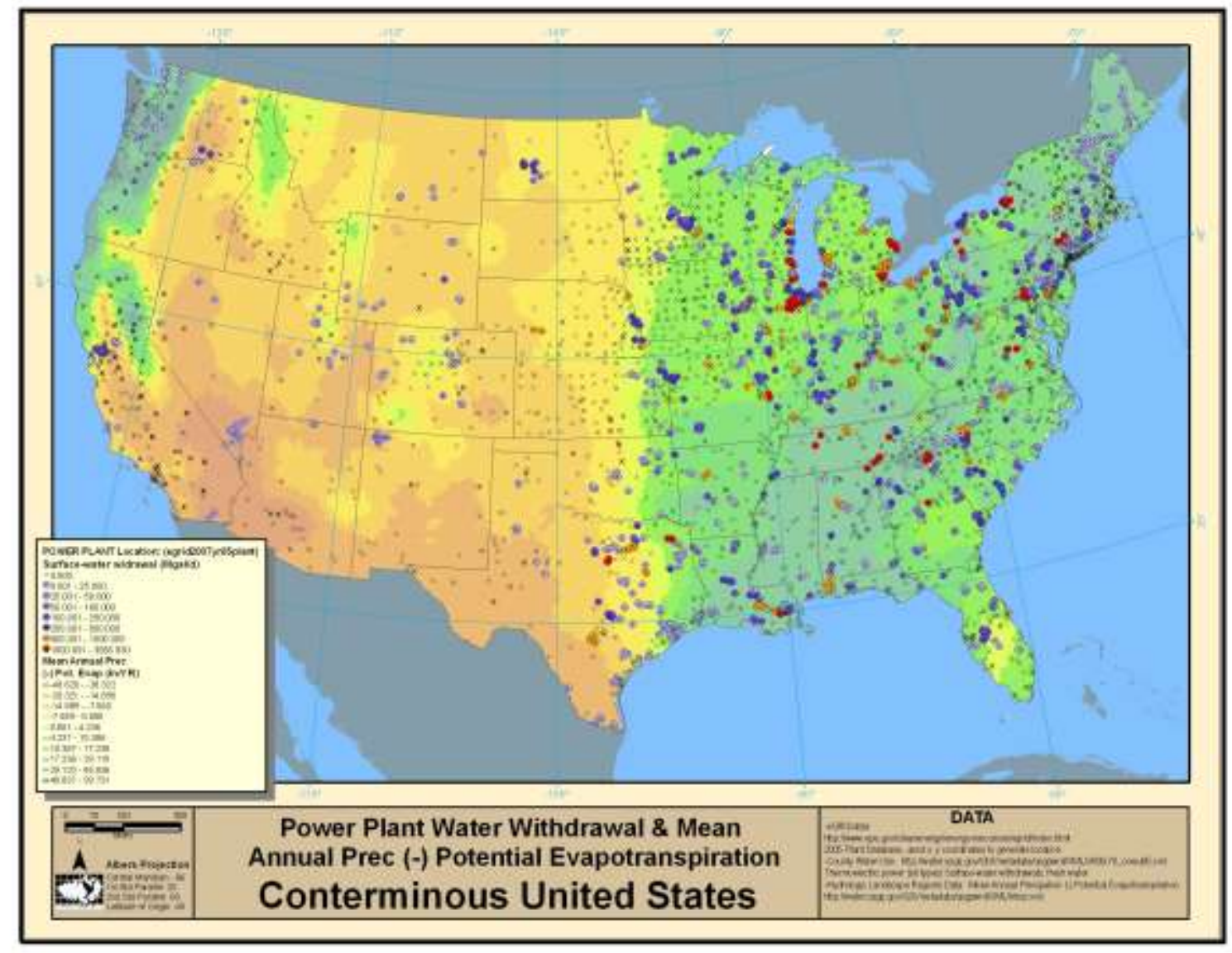

Figure 10. Power Plant Water Withdrawal and Difference between Mean Annual Precipitation and Potential Evapotranspiration. 


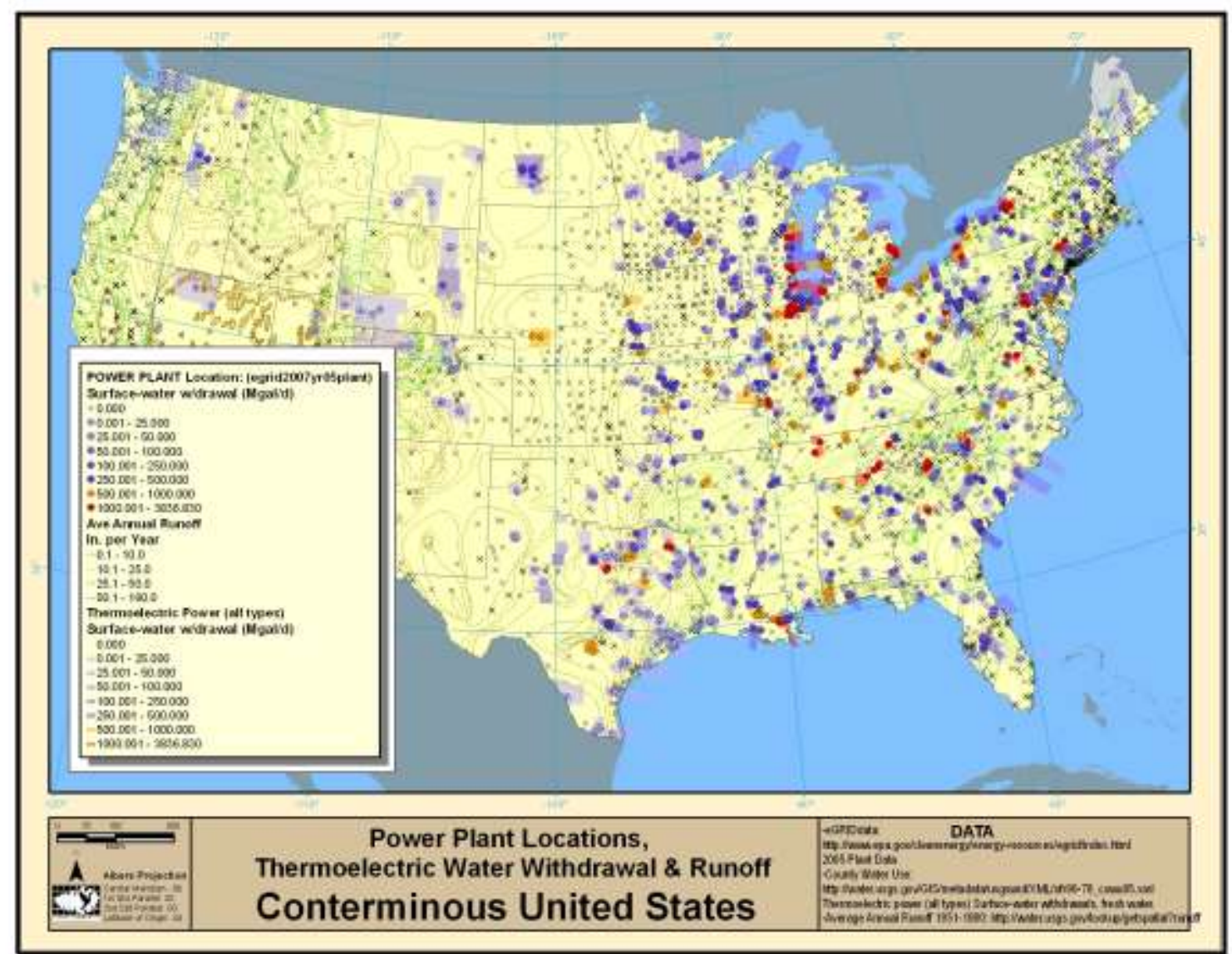

Figure 11. Power Plant Locations, Thermoelectric Water Withdrawal, and Stormwater Runoff.

\section{Economic Assessment of Cooling Wetlands}

The economic viability of a cooling wetland system depends in large part on the costs for the wetland system. The placement of constructed wetlands can greatly affect their success in capturing or harvesting water and the frequency and timing of this harvest. This can also benefit and affect wetland costs. For example, the least expensive created wetlands are placed in locations with the appropriate topographic relief requiring a minimum of earth moving to create the dikes or depressional area containing the wetland. Typically, such appropriate locations are found in floodplains or existing depressional landforms within a watershed.

Capturing flood flows by placing the created wetland adjacent to and within the floodplain of an urban river can provide 2-7 bankfull annual flood events which can fill the wetland with water. Likewise, within a heavily drained (e.g. tiled and ditched) agricultural watershed, often several annual bankfull floods typically occur to fill a created wetland. Some wetlands can be placed to both capture overbank flooding from 
a river or stream and the perennial or intermittent runoff from the subwatershed that may be tributary to the larger river or stream.

Locating wetlands to take advantage of natural depressional areas to reduce grading is critical to reduce the grading costs of wetlands. Depressional area wetlands also take advantage of existing hydric soils for the seedbanks which contain many of the desirable native wetland plant species that will reduce the seeding and planting requirements of the construction budget.

Land Acquisition Costs - Land costs were not included in this economic assessment for several reasons. First, we found most coal-fired (and even other types of) power plants own considerable buffer land acreages abutting the power plants which could be used for wetland systems without additional land purchase. Our conversations with power company personnel also suggested that the decision to use a wetland will not typically hinge on land cost, especially for the companies that already own sufficient and appropriate lands, but on the actual computed and projected benefits provided by the created wetlands. Secondly, because land costs vary considerably depending on the geographic region and the nature of the land and its highest and best use, the real added information we could contribute in this study are land area needs for a wetland system and construction cost comparisons for the wetland system.

Construction and Maintenance Costs - As a part of this study, construction cost figures for wetlands of varying volumes and areas were developed to provide a basis for establishing expected construction costs for cooling wetland systems. These construction cost values were developed for several elements of wetland construction, including wetland grading and earthmoving operations, wetland soil preparation, wetland vegetation, and outlet/inlet water control structures. As can be expected, many of the wetland elements would benefit from economies of scale with larger wetlands being less expensive on a per acre basis than smaller wetlands. Varying wetland sizes were included in the cost assessment.

Additionally, post-construction maintenance will be required until the wetland vegetation is established and long-term maintenance will be required after establishment, while the wetland remains operational. Finally, monitoring costs will likely be incurred to evaluate the wetland's ecological performance if this performance is included as part of the wetland's value.

Wetland grading and earthmoving operations would be one of the higher costs in wetland construction. Thus, wetland economic viability would be highest in areas requiring the least grading. For the purposes of this very general economic analysis, grading costs were developed for wetlands with water storage depths varying from 1 to 5 feet with the following assumptions:

- The top twelve inches of topsoil would be excavated, stockpiled, and replaced and reused over the graded wetland. 
- Wetlands would be located in depressional areas which could be bermed to provide at least one-foot of water storage depth without excavation (where in this scenario, existing topsoil would remain in place).

- Wetlands with storage depths between 2 and 5 feet could be constructed within diked berms in excavated areas. The least cost, by far, would be achieved by constructing wetlands within diked berms in lieu of excavating depressional storage.

- Excavation unit costs were estimated to vary from $\$ 3.50$ per cubic yard for wetlands requiring over 30,000 cubic yards of excavation to $\$ 6.00$ per cubic yard for wetlands requiring less than 2,000 cubic yards of excavation.

- Topsoil excavation, stockpile and replacement costs were estimated to vary from $\$ 3.50$ per cubic yard for wetlands requiring over 30,000 cubic yards of topsoil excavation to $\$ 8.00$ per cubic yard for wetlands requiring less than 2,000 cubic yards of topsoil excavation.

Costs for soil preparation included herbicide treatment of any existing invasive or weedy vegetation and disking of the surface soil for $\$ 80$ per acre.

Costs for planting would vary from $\$ 2,000$ per acre for smaller wetlands to $\$ 800$ per acre for larger wetlands and include seeding of the shallow wetlands and emergent planting of the deeper wetlands.

Costs for the wetland hydraulic control structures would vary from $\$ 15,000$ for smaller wetlands to $\$ 120,000$ for larger wetlands.

Vegetation management during the wetland establishment period would include initial weed control by mowing and wick herbicidal management and spot-spraying. Remedial planting would be required for some percentage in each restoration where plantings failed during establishment (failure can result from herbivory from Canada geese, water turbidity, extreme water level fluctuation during the critical establishment period, etc.). The cost was estimated to vary from $\$ 340$ per acre for smaller wetlands to $\$ 260$ per acre for larger wetlands.

Vegetation management after the wetland establishment period was estimated as a present worth amount necessary to provide for this ongoing maintenance. The annual cost is estimated to vary from $\$ 1,500$ per acre for smaller wetlands to $\$ 90$ per acre for larger wetlands. Additionally, some monitoring of established wetlands may be necessary to verify the ecological function of the wetlands. The present worth amount for this monitoring varies between $\$ 3,300$ per acre for small, 10 -acre wetlands to $\$ 48$ per acre for wetlands over 10,000 acres.

All cost assumptions are very conservative. For example, depending on the project site, wetland maintenance may not be necessary.

The costs for cooling water wetlands used in the economic analysis reflect the values previously discussed in this section: 
Table 5. Costs Excluding Earthwork.

\begin{tabular}{|l|r|r|r|r|}
\hline \multirow{2}{*}{ Item } & \multicolumn{4}{|c|}{ Wetland Size } \\
\cline { 2 - 5 } & \multicolumn{1}{|c|}{$\mathbf{1 0}$ acres } & $\mathbf{1 0 0}$ acres & \multicolumn{1}{c|}{$\mathbf{1 , 0 0 0}$ acres } & \multicolumn{1}{|c|}{$\mathbf{1 0 , 0 0 0}$ acres } \\
\hline Soil Preparation & $\$ 800$ & $\$ 8,000$ & $\$ 80,000$ & $\$ 8,000,000$ \\
\hline Vegetation & $\$ 20,000$ & $\$ 200,000$ & $\$ 1,500,000$ & $\$ 8,000,000$ \\
\hline Hydraulic Control Structures & $\$ 22,500$ & $\$ 60,000$ & $\$ 75,000$ & $\$ 120,000$ \\
\hline $\begin{array}{l}\text { Vegetation Maintenance } \\
\text { (Establishment) }\end{array}$ & $\$ 1,500$ & $\$ 15,000$ & $\$ 150,000$ & $\$ 900,000$ \\
\hline $\begin{array}{l}\text { Vegetation Maintenance and } \\
\text { Monitoring (Post-establishment) }\end{array}$ & $\$ 33,000$ & $\$ 69,300$ & & \\
\hline TOTAL & $\$ 77,800$ & $\$ 352,300$ & $\$ 1,964,400$ & \\
\hline
\end{tabular}

The costs for earthwork grading will vary greatly depending on the extent of excavation required to provide the depressional storage volume for the wetlands. The least expensive alternatives would involve constructing dikes around the wetland area to a height sufficient to store wetland water to an appropriate depth. The most expensive alternatives would require excavation of the wetland area to an appropriate depth. The wetlands would likely be located to maximize the use of earthen dikes and minimize the amount of excavation. Costs are tabulated for both the least-cost diked option and the most-cost completely excavation option (Table 6 ) to point out that for larger wetlands, the complete excavation option is about 30 times more expensive than the diked option.

Table 6. Earthwork Costs: Diked vs. Complete Excavation Options (in thousands of dollars).

\begin{tabular}{|c|c|c|c|c|}
\hline $\begin{array}{c}\text { Wetland Water Storage Depth } \\
\text { (feet) }\end{array}$ & \multicolumn{4}{|c|}{ Wetland Size } \\
\cline { 2 - 5 } & $\mathbf{1 0}$ acres & $\mathbf{1 0 0}$ acres & $\mathbf{1 , 0 0 0}$ acres & $\mathbf{1 0 , 0 0 0}$ acres \\
\hline 1 & $\$ 29.3 / 12.4$ & $\$ 88.6 / 99.6$ & $\$ 217.1 / 871.1$ & $\$ 665.6 / 8,711.1$ \\
\hline 2 & $\$ 48.1 / 161.3$ & $\$ 131.7 / 1,129.3$ & $\$ 372.5 / 11,293.3$ & $\$ 1,152.5 / 112,933.3$ \\
\hline 3 & $\$ 71.6 / 177.5$ & $\$ 180.0 / 1,694.0$ & $\$ 569.1 / 16,940.0$ & $\$ 1,769.4 / 169,400$ \\
\hline 4 & $\$ 97.5 / 233.9$ & $\$ 255.1 / 2,258.7$ & $\$ 806.7 / 22,586.7$ & $\$ 2,516.1 / 225,866.7$ \\
\hline 5 & $\$ 129.0 / 290.4$ & $\$ 343.2 / 2,823.3$ & $\$ 1,085.3 / 28,233.3$ & $\$ 3,392.7 / 282,333.3$ \\
\hline
\end{tabular}

*diked wetlands excavation costs/completely excavated wetland costs in thousands of dollars per wetland

The diked and completely excavated wetland construction options are combined with the costs excluding earthwork and tabulated on a per acre-foot of water storage volume basis (Table 7) to allow comparison with other reservoir systems. 
Table 7. Total Wetland Costs: Diked vs. Complete Excavation Options (in thousand of dollars per acre-foot of storage volume).

\begin{tabular}{|c|c|c|c|c|}
\hline \multirow{2}{*}{$\begin{array}{c}\text { Wetland Water Storage Depth } \\
\text { (feet) }\end{array}$} & \multicolumn{4}{|c|}{ Wetland Size } \\
\cline { 2 - 5 } & $\mathbf{1 0}$ acres & $\mathbf{1 0 0}$ acres & $\mathbf{1 , 0 0 0}$ acres & $\mathbf{1 0 , 0 0 0}$ acres \\
\hline 1 & $\$ 10.7 / 9.0^{*}$ & $\$ 4.4 / 4.5$ & $\$ 2.2 / 2.8$ & $\$ 1.8 / 2.6$ \\
\hline 2 & $\$ 6.3 / 12.0$ & $\$ 2.4 / 7.4$ & $\$ 1.2 / 6.6$ & $\$ 0.9 / 6.5$ \\
\hline 3 & $\$ 5.0 / 8.5$ & $\$ 1.8 / 6.8$ & $\$ 0.8 / 6.3$ & $\$ 0.6 / 6.2$ \\
\hline 4 & $\$ 4.4 / 7.8$ & $\$ 1.5 / 6.5$ & $\$ 0.7 / 6.1$ & $\$ 0.5 / 6.1$ \\
\hline 5 & $\$ 4.1 / 7.4$ & $\$ 1.4 / 6.4$ & $\$ 0.6 / 6.0$ & $\$ 0.4 / 6.0$ \\
\hline
\end{tabular}

*diked wetlands total cost per acre foot/completely excavated wetlands total cost per acre foot in thousands of dollars per acre-foot of storage volume

\section{Cleansing}

While not a focus of this study, an important, documented benefit is the capability of constructed wetlands to provide water or wastewater treatment or polishing. The ability of constructed wetlands to remove a variety of contaminants from the water flowing through them has been studied extensively (Brix, 1993; Kadlec and Knight, 1996; Knight et al., 1993; Reed et al., 1995). Wetlands are capable of removing such waterborne contaminants as suspended solids, metals, nutrients, and organic materials. A DOEfunded Clemson University study has extensive information about the treatment capabilities of a pilot-scale constructed wetland for several common thermoelectric power plant wastewater streams (Rodgers and Castle, 2008). The Clemson study includes information about the water treatment function of a constructed wetland for power plant water streams such as cooling tower blowdown, FGD waste water, and bottom ash transport slurry. These streams will typically be receiving treatment. While not within the scope of this study, the effluent(s) from such treatment ponds/systems may benefit from additional polishing by passing through a constructed wetland designed for cleaning the specific effluent.

At SaskPower, a constructed wetland in use at a power plant takes in wastewater effluents from a nearby municipality for flow through and treatment by the wetland. As noted above, studies indicate constructed wetlands can provide a cost-effective polishing strategy to remove scale-producing cations in the boiler and cooling and condenser units (SaskPower, 2003).

Treated effluent from wastewater treatment plants represents a substantial volume and consistent flow of water, and one that often requires final treatment and polishing before being discharged safely into the environment. Wetlands can provide this service because they are very effective at removing physical pollutants (e.g., sediments), chemical pollutants (e.g., nitrogen and phosphorus), and biological pollutants (e.g., pathogens) - all concerns associated with wastewater treatment plant effluent. Employing wetlands in a treatment/polishing capacity can be a very cost-effective means of providing power plants with a consistent flow of treated water for facility operations (e.g., cooling water). A system of connected wetland cells could be designed to provide integrated treatment/polishing of wastewater treatment plant 
effluent, cooling water supply to power plants, and cooling services to power plant effluent. These treatment/polishing/cooling wetlands can be designed to provide other benefits, including improved water quality, wildlife habitat, and opportunities for fishing, bird watching, and other passive recreation.

\section{Wetlands' Role in Global Carbon Cycle and Greenhouse Gas Emissions}

Wetlands play a critical role in global carbon cycling (including carbon dioxide emissions) and have a substantial influence over other, even more potent, greenhouse gases (GHGs). On a global scale, wetlands comprise the largest pool of stored carbon, representing $33 \%$ of the soil organic matter (SOM) on only about $4 \%$ of the land surface area (Eswaran et al., 1993). Wetland soils can range from organic soils (e.g., mucks, peats) to mineral soils (e.g., sands, loams, silts, and clays). Wetland (hydric) soils tend to have high SOM, and hence high soil organic carbon (SOC). Carbon is stored in wetlands via SOM and live vegetation (above-ground and below-ground).

Wetlands (including natural, drained, and constructed systems) have the potential to emit three significant GHGs: carbon dioxide $\left(\mathrm{CO}_{2}\right)$, methane $\left(\mathrm{CH}_{4}\right)$, and nitrous oxide $\left(\mathrm{N}_{2} \mathrm{O}\right.$ ). While much attention is paid to $\mathrm{CO}_{2}$ emissions (and rightfully so), $\mathrm{CH}_{4}$ and $\mathrm{N}_{2} \mathrm{O}$ emissions from wetlands play significant roles in the net effect on GHGs (Li et al., 2004). All three GHGs emitted from wetlands have been increasing in the atmosphere. The concentrations of $\mathrm{CO}_{2}, \mathrm{CH}_{4}$ and $\mathrm{N}_{2} \mathrm{O}$ in the atmosphere were $37 \%, 156 \%$ and $19 \%$ above the pre-industrial levels in 2007 (WMO, 2008).

Drained wetland soils lose SOC through oxidation/decomposition, which leads to increased $\mathrm{CO}_{2}$ emissions. While wetland drainage typically results in a reduction in $\mathrm{CH}_{4}$ emissions, $\mathrm{N}_{2} \mathrm{O}$ emissions may increase. Conversely, restoring (rehydrating) previously drained wetlands has the potential to decrease $\mathrm{CO}_{2}$ emissions (by increasing $\mathrm{SOC}$ ) and decrease $\mathrm{N}_{2} \mathrm{O}$ emissions, but increase $\mathrm{CH}_{4}$ emissions.

Generally, wetlands are a natural source of methane $\left(\mathrm{CH}_{4}\right)$, with estimated emissions of 55-150 Tg CH4 yr-1 (Watson et al., 2000). Wetlands appear to be the largest source of $\mathrm{CH}_{4}$, contributing about $20 \%$ of the annual global emission to the atmosphere (Wang et al., 1996), and Sovik et al (2006) reported that $\mathrm{CH}_{4}$ contributes to $25 \%$ of the global warming (Mosier, 1998). $\mathrm{CH}_{4}$ is a very potent $\mathrm{GHG}$ with a global warming potential (GWP) of 21 times the GWP of $\mathrm{CO}_{2}$ (Intergovernmental Panel on Climate Change, 1996) and 25 times the GWP of $\mathrm{CO}_{2}$ when viewed in a 100-year time horizon (Solomon et al., 2007).

Maljanen et al (2009) found that $\mathrm{N}_{2} \mathrm{O}$ is a more efficient $\mathrm{GHG}$ than $\mathrm{CO}_{2}$. With a 100year time horizon its GWP is 298 times that of $\mathrm{CO}_{2}$ (Solomon et al., 2007). $\mathrm{N}_{2} \mathrm{O}$ persists about as long as $\mathrm{CO}_{2}$ in the atmosphere (approximately 120 years) whereas $\mathrm{CH}_{4}$ only lasts for 12-15 years (US EPA, 2003). Sovik et al (2006) reported that $\mathrm{N}_{2} \mathrm{O}$ is responsible for about $5 \%$ of the global warming (IPCC, 2001). $\mathrm{N}_{2} \mathrm{O}$ is produced in soils mainly by the microbial processes of nitrification and denitrification (Prieme' and Christensen, 2001). Generally, $\mathrm{N}_{2} \mathrm{O}$ emissions from saturated ecosystems are very low, 
unless there is a sustained supply of exogenous nitrogen (IPCC, 2006). Nitrogen fertilizers common in agricultural areas enhance the emission of $\mathrm{N}_{2} \mathrm{O}$ (Thornton and Valente 1996, Davidson et al., 2000).

Because the production of $\mathrm{CH}_{4}$ and $\mathrm{N}_{2} \mathrm{O}$ in wetlands vary with hydrologic regime, soil properties, vegetation, and climate, understanding these parameters is critical for assessing potential wetland greenhouse gas implications associated with incorporating wetlands into power plant operations.

\section{$\underline{\text { Relevant Wetland Types }}$}

Different wetland types have been found to sequester varying quantities of carbon and emit varying quantities of GHGs. The wetland types that are most likely to be incorporated into power plant water storage, treatment, and/or cooling operations are floodplain wetlands, fresh water marshes, and constructed treatment wetlands. Although saltwater marshes are less desirable as water storage and reuse due to high salt concentrations, they may still be incorporated into a discharge treatment system, so information on those wetlands is also presented here.

\section{Flooded Lands and Floodplain Wetlands}

An IPCC report (2006) states that flooded lands (in the context of anthropogenically flooded areas for reservoirs and hydropower) may emit $\mathrm{CO}_{2}, \mathrm{CH}_{4}$ and $\mathrm{N}_{2} \mathrm{O}$ in significant quantities, depending on a variety of characteristics such as age, land-use prior to flooding, climate, and management practices. Emissions vary spatially and over time. The effect of non-point nutrient sources to flooded lands (reservoirs) also remains poorly documented, but nutrient-rich runoff (e.g., nitrogen from agricultural fields) has been found to increase $\mathrm{N}_{2} \mathrm{O}$ emissions from wetlands (Euliss, unpublished data). Ballantine and Schneider (2009) summarized several studies in which constructed riverine floodplain wetland SOM ranged from $2 \%$ to $12 \%$ of the soil mass.

\section{Prairie Potholes and Freshwater Marshes}

Many inland freshwater wetlands have been drained and cultivated, resulting in a potentially significant release of $\mathrm{CO}_{2}$ from aerobic decomposition of previously sequestered carbon. Euliss (unpublished data) stated that wetland buffers can be utilized to mitigate sediment and nutrient import into wetlands and to curtail the subsequent wetland enrichment process and the release of trace gas emission (e.g., $\mathrm{N}_{2} \mathrm{O}$ ). Euliss et al (2006) suggests that, 1) the overall organic carbon content of prairie wetlands is comparable to native grasslands (Blank and Fosberg, 1989), but the rate of carbon sequestration is approximately five times higher in constructed wetlands than restored grassland (Follett et al., 2001), and 2) converting cultivated cropland to perennial vegetation within created wetland catchments should reduce nutrient enrichment in constructed wetlands and lower emissions of $\mathrm{N}_{2} \mathrm{O}$, and possibly $\mathrm{CH}_{4}$ from wetland basins. Ballantine and Schneider (2009) summarized several studies in which 
restored freshwater marshes were found to have SOM ranging from less than $0.1 \%$ to $23 \%$ of the soil mass.

\section{Constructed Treatment Wetlands}

Sovik et al (2006) reported that the studies conducted so far have indicated that constructed wetlands (usually used for some form of wastewater/runoff/effluent treatment) have high $\mathrm{N}_{2} \mathrm{O}$ and $\mathrm{CH}_{4}$ emissions, especially during the summer. This is believed to be at least in part due to either nutrient-enriched or other polluted influent, which enhances GHG emissions. Relatively clean water from power plant operations would not be expected to have such contaminants that would enhance GHG emissions. Also, due to their generally small area, constructed wetlands are believed to represent only a minor source for atmospheric $\mathrm{N}_{2} \mathrm{O}$ and $\mathrm{CH}_{4}$.

\section{Tidal Marshes \& Mangrove Swamps}

Much attention has been given to the role of freshwater wetlands, particularly northern peatlands, as carbon sinks. In contrast to peatlands, salt marshes and mangroves release negligible amounts of GHGs and store more carbon per unit area. The presence of abundant sulfate in tidal saline wetland (TSW) soils hinders $\mathrm{CH}_{4}$ production, so these ecosystems are considered to be negligible sources of $\mathrm{CH}_{4}$, if not $\mathrm{CH}_{4}$ sinks (Bartlett and Harris, 1993; Magenheimer et al., 1996; Giani et al., 1996). The combination of greater carbon burial and possibly lower $\mathrm{CH}_{4}$ emissions means that TSWs could be more valuable as carbon sinks per unit area than peatlands if anthropogenic activity or natural processes were to increase ecosystem $\mathrm{CO}_{2}$ assimilation and burial (Whiting and Chanton, 2001). According to PWA \& SAIC (2009), all tidal marshes are generally net sinks for atmospheric $\mathrm{CO}_{2}$ through burial of organic matter in sediment. Ballantine and Schneider (2009) summarized several studies in which restored saltmarshes were found to have SOM ranging from less than $0.1 \%$ to $9.4 \%$ of the soil mass. However, GHG emissions from tidal wetlands may be significantly affected by changes in sea level and erosion events, which could convert GHG sinks to sources.

\section{$\underline{\text { Conclusions }}$}

Wetlands sequester significant quantities of carbon; therefore, creating and restoring wetlands has the ability to increase carbon sequestration. However, wetlands should be designed and managed to maintain conditions that do not favor production of GHGs. If GHG reduction credit is desired as part of wetland creation projects associated with power plant operations, those projects must thoroughly assess all GHG components and relationships over time under both existing environmental conditions as well as projected future conditions, since projected changes in climate and subsequent changes in ecosystem structure, composition, and disturbance regimes could have significant effects on sequestration/sink projects, even reversing predicted/intended trends. 


\section{Plant and Wildlife Habitat}

One of the most recognized functions of wetlands is providing habitat for flora and fauna. Wetlands provide the soil, moisture, nutrients, and growth media for thousands of plant species - many of which can survive only in wetlands. In turn, these wetland plant communities provide water, food, and shelter for insects, shellfish, fish, birds, and mammals. Wetlands also provide critical migration stopover habitat, breeding grounds, and nurseries for many animals. A large number of plants and animals that are listed as threatened, endangered, or special concern species depend on wetlands for their survival (almost one-half of the federally threatened and endangered species rely directly or indirectly on wetlands).

Not all wetlands perform all functions, and individual wetlands do not perform these functions equally well because of variation in size, wetland type, and watershed location. A wetland's size as well as its design and shape (notably the perimeter to area ratio) affects its ability to provide wildlife habitat for interior versus edge species. Shape is also important as it pertains to wildlife movement within the habitat and between habitats. Wetland size is most important for larger and wide-ranging animals that use wetlands as a refuge or food and shelter.

\section{Stakeholder Involvement}

As part of our original scope, the AES/SES Team has developed a database of potential stakeholders (e.g., landowners, public land managers, water treatment facilities, other implementers, carbon-generating industry and business groups, investors and carbon credit purchasers, environmental groups, public policy interest groups, government agencies and regulators, mass media, and educational and research institutions) who may be interested in the use of constructed wetlands for water cooling and makeup supply. Microsoft Access has been used as a framework for the database.

The stakeholder database was developed from a variety of sources. Pre-existing contact databases were mined for their relevant entries. These are individuals, agencies, or organizations the AES/SES Team has worked with in the past and will have a vested interest in cooling pond restoration/retrofits. Additionally, the following broad list of categories was developed:

- Energy

- Producers - Individual Power Plants, Energy Cooperatives, and Energy Conglomerates

- Consumers - Consumer Advocacy Groups and Large Consumers (Google in particular is the largest consumer of energy in the world)

- Natural Resource Groups - Oil, Coal, and Natural Gas Industry

- Third Party Watchdogs

- Ecology \& Environment

○ Private-sector, for-profit firms - Restoration Consulting Firms, Planning Firms 
- Private-sector, non-profit Organizations - Advocacy Groups, Research Organizations

- Government

- Federal Agencies - US Fish and Wildlife Society, US Environmental Protection Agency, NRCS

- State Agencies - Departments of Natural Resources, Departments of Environmental, Economic Development Agencies

- Special Use Districts - Regional Planning Organizations, Water and Sewerage Districts/Departments

- Local Units of Government

- Research and Education

- Universities

Web research was conducted to find specific organizations which fit into these four distinct categories referencing the particular sub categories (also shown above). Specific stakeholders were added to the database based on their relative interest in the project and the potential power they possess in influence the final outcome. For example, individual power plant managers may have a high degree of interest in improving their cooling ponds, but very little power; whereas, conversely, corporate executives may have the power, but little, real interest. The ultimate targets were keystone individuals that will improve the chances of program success. Organizations or firms who have no interest or power, but may benefit from these activities indirectly were not included at this time. A listing of the stakeholders identified to date in included in the Appendix (Stakeholder Database Listing).

\section{Challenges}

\section{Ecological Impacts of Thermal Discharges}

Thermal discharges have long been an issue with power plant operations. Part of this project included the assessment of the effect of thermal discharges on potential receiving wetlands, and how ecological integrity of a receiving water ecosystem might be sustained and perhaps enhanced under a variety of cooling wetland-use scenarios. This portion of the project consisted primarily of a literature review and synthesis of collected data (e.g., journal articles, technical books, and governmental guidance documents). In addition, our literature review was augmented by discussions with agency representatives, researchers, and project Team members.

The literature review focused on impacts to aquatic biota (plants and animals) as a result of thermal discharges. Additional research was conducted on related topics of indices of biotic integrity (IBIs), total maximum daily loads (TMDLs), lethal temperature ( $\left.L T_{50}\right)$, and related studies, to see how these might inform a thermal condition ranking framework.

Over 150 related research papers and related resources were identified, about half of which had direct relevance to our research (see References - Chapter 4 - Thermal 
Tolerance of Aquatic Biota). Articles, books, and other resources were reviewed and sorted with regard to their applicability to this study. Data were organized by life forms, general tolerance to thermal discharges, temperature thresholds, and miscellaneous notes and graphics.

Research findings addressed a broad range of fauna, flora, thermal effects and tolerances, geographies, and other environmental variables (marine to freshwater, regulated rivers, etc.). Compilation of these data revealed the diversity and specificity of most studies, as well as the complexity of critical variables often intermingled with thermal discharges. This made comparison and integration of various studies challenging for application to a wide range of cooling water scenarios. Based on this complexity, we decided to focus on the anticipated ecological effects of thermal discharges into temperate, warm water, freshwater wetlands.

\section{Effects of Increased Temperature on Aquatic Biota}

The direct and indirect effects of increased water temperatures on various aquatic life forms have been well-documented in numerous studies; however, the complex relationships between these effects can make accurate predictions challenging. For example, warmed waters often result in increased algae growth, which alters the primary production of the ecosystem, reduces light availability, and affects the species composition of flora and fauna (multiple authors, including Welch and Jacoby 2004). Common effects that heated effluent can have on aquatic communities include:

- Thermal stratification of habitat - warmer surface water, cooler deep water;

- Primary and secondary production - increased;

- Decomposition and biological oxygen demand (BOD) - increased;

- Dissolved oxygen - reduced (while faunal demand is increased);

- Respiration, growth \& feeding rates - generally increased;

- Life cycles - generally accelerated (e.g., earlier trigger for reproduction cycles, earlier emergence for aquatic macroinvertebrates);

- Sex ratios - warmer water can result in greater proportion of females in some species (e.g., turtles);

- Community composition/succession - generally shifts towards warmer-water communities

- Susceptibility to predation, parasites and diseases - variable; and

- Toxicity of poisons - variable.

Of course many of these generalized trends slow, cease, or reverse once critical thresholds are exceeded. Threshold exceedances may result from a thermal change's magnitude, duration, frequency, rate, or a combination of these factors.

Heated effluents can also provide artificial environments for aquatic flora and fauna from warmer climates. Therefore, warm water discharges have been identified as confirmed entry points for non-native, invasive, or otherwise undesirable aquatic plants and animals (Wang et al 2005). 


\section{Thermal Tolerance of Biota}

For most animals that have been studied, the upper critical temperature (i.e., the maximum body temperature that can be tolerated by an organism) lies in the range $30^{\circ}-$ $45^{\circ} \mathrm{C}$, while few plants can survive leaf temperatures in excess of $50^{\circ} \mathrm{C}$, exceptions being desert plants such as agaves and cacti, which can tolerate temperatures of $60^{\circ} \mathrm{C}$ or more (Encyclopedia.com 2004). Numerous studies have examined the thermal tolerance of different aquatic biota, with the majority of this research focusing on fish, and relatively little research has addressed flora. The thermal tolerance of various life forms can be affected significantly by a variety of environmental and organismal factors (Esch and McFarlane 1976), and some of factors can interact synergistically. Environmental and organismal factors affecting thermal tolerance include:

- Seasonal changes and photoperiod;

- Diel changes (daily temperature and light cycles);

- Geographic and climatic variation;

- Habitat variation (e.g., stream vs. lake);

- Chemical composition of water;

- Temperature change's magnitude, duration, frequency, rate, or a combination of these factors;

- Acclimation temperature and time for organism to acclimate;

- Presence of refugia (for mobile life forms);

- Organism's stage of development (young often have less thermal tolerance);

- Organism's diet and nutritional status;

- Organism's water content;

- Organism's behavior/activity.

The effects of thermal discharges are frequently confounded by other, simultaneous environmental changes (e.g., hydrologic alteration, water quality changes, water bodyspecific trophic changes). It is also important to note that severe impairments to aquatic biota can occur below lethal thresholds, leading to death. In response to thermal warming, many populations will pass through a positive response phase prior to the negative response (Gibbons 1976). Due to the complex relationships between environmental conditions of receiving waters and the biotic communities that inhabit them, it is, "unwise to attempt generalizations on the effects of thermal pollution; each case must be considered individually" (Abel 1996).

\section{$\underline{\text { Regulatory Guidance and Temperature Criteria for Thermal Discharges }}$}

While not exhaustive, several federal and state guidance documents were reviewed for thermal discharge recommendations. These criteria were developed to maintain a reasonable level of ecological integrity in thermal effluent receiving waters. The USEPA's Quality Criteria for Water (also known as the Gold Book) as well as several state guidelines for thermal criteria were reviewed. General nationwide guidance for warm waters states that rise above ambient temperature should be $\leq 2.8^{\circ} \mathrm{C}$ (for streams) 
and $\leq 1.7^{\circ} \mathrm{C}$ (for lakes), never exceeding an absolute temperature of $32^{\circ}-34^{\circ} \mathrm{C}$ (depending on the area) nor a rate $\geq 3^{\circ} \mathrm{C} / \mathrm{hr}$ (USEPA 1986).

\section{Development of a Thermal Condition Ranking Framework}

Based on our data compilation and assessment, a thermal condition ranking framework was developed to categorize the ecological integrity of thermal effluent receiving waters. Table D in Appendix-Chapter 4 summarizes much of the data reviewed, focusing on warm water and cool water species of the Upper Midwest. Figure 12 illustrates the thermal condition ranking framework. It is acknowledged that the ranking framework (e.g., temperature zones, biotic community) would need to be adjusted for projectspecific conditions.

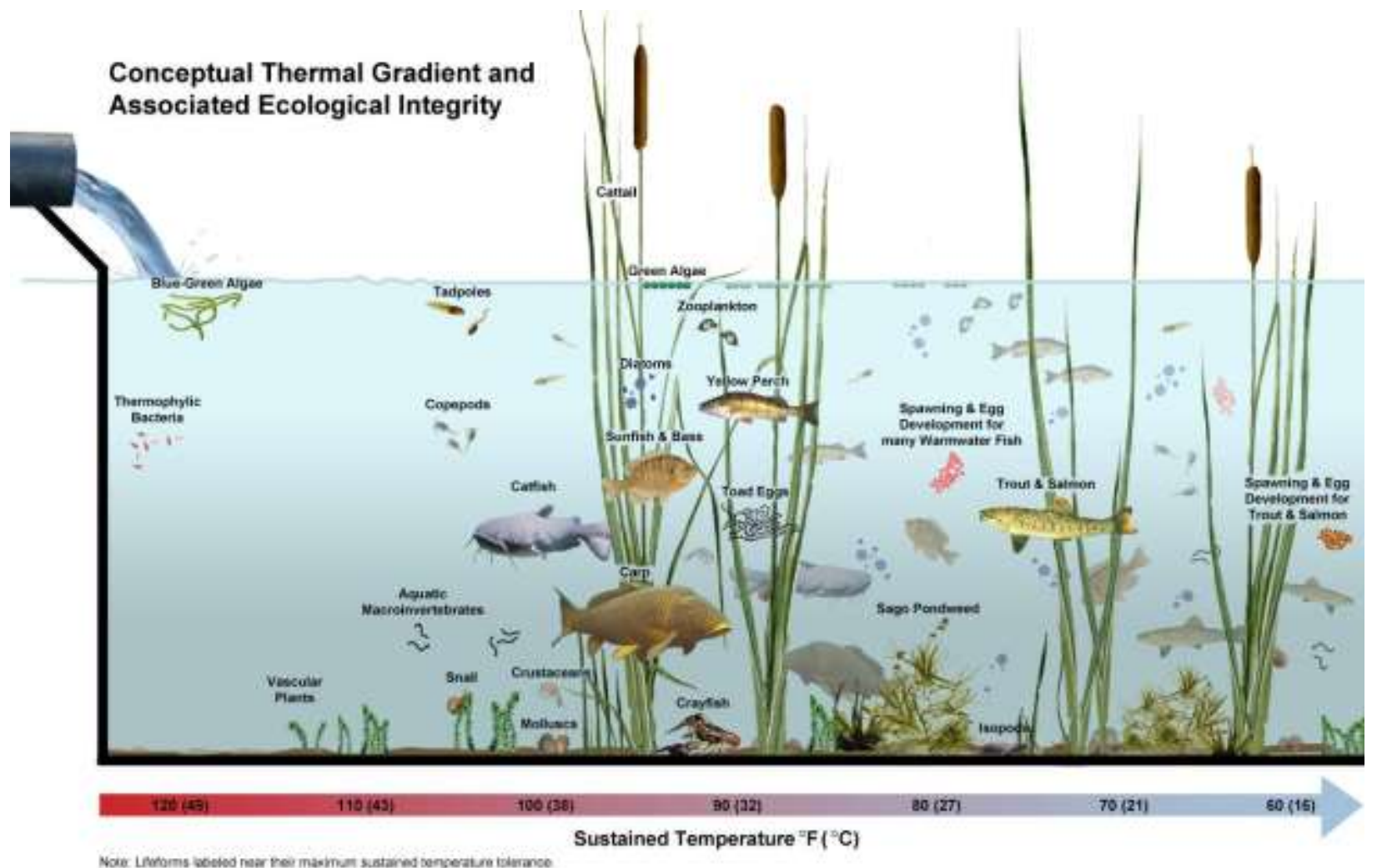

Figure 12. Conceptual Thermal Gradient and Associated Ecological Integrity.

Often more important than absolute temperature is deviation from ambient. Several warm water temperature criteria prescribe a maximum increase of $2^{\circ} \mathrm{C}$ above ambient; however, criteria typically vary depending on the type and quality of receiving waters, and many species can tolerate temperature increases of greater magnitude. It is important to note that the thermal tolerance of adult fauna is often significantly higher than the thermal tolerance of that same species to reproduce. Therefore, an understanding of biotic life cycles is important to projecting an ecosystem's ecological integrity and sustainability. 
Based on our literature review, data compilation, and assessment, it is possible to estimate the ecological integrity of a receiving water based on the anticipated thermal regime of the system. However, additional assessment will be required to assess a specific project's effect on a specific receiving water(s). Cooling water projects that attempt to retain or restore ecological integrity to its receiving water(s) should consider the following practices:

1. Understand the receiving water's biotic communities (both species present and/or those desired), trophic structure, and environmental tolerances (e.g., thermal, water quality);

2. Understand the receiving water's hydrologic system (surface water and groundwater inputs and outflows) and water quality parameters;

3. Develop a management system that allows for control of the receiving water's temperature and water quality parameters;

4. Minimize rapid changes in the receiving water's temperature;

5. Provide connectivity between pond/wetland cells to enable mobile fauna to access refugia if needed;

6. Provide sufficient water temperatures so that desirable biota can complete critical life cycle processes (e.g., reproduction). This will typically require seasonal periods of cooler temperatures; and

7. Assess the effects that global climate change will likely have on the receiving water(s) and aquatic communities.

\section{Case Studies}

\section{Hines Energy Complex}

An excellent example of using natural surface waters in conjunction with power production is at Duke Energy Florida's, Hines Energy Complex in central Florida. (Note: The site was previously owned by Progress Energy Florida until they were acquired by Duke in early 2013.) This facility is located in an area characterized by highly competing demands for freshwater, including a rapidly growing local population (residential and commercial uses), longstanding industrialized mining operations, agriculture, and the need for more power generation resources. The Hines Energy Complex is similar to the majority of power generation projects constructed in the past twenty years in that it is a 2,000 MW, natural gas fired, combined cycle power plant that operates large gas turbines combined with heat recovery steam generators to produce electricity from the gas turbines, and then capture the waste heat to generate additional electricity using a conventional steam cycle. The steam turbine cycle totals about $600 \mathrm{MW}$ and is cooled with a closed-cycle cooling pond of 1,200 acres. What is not characteristic of other similar sized projects is that from a water supply and use perspective, the Hines operation is a closed loop water supply and beneficial re-use system, which relies extensively on alternative supplies and water harvesting from wetland systems.

There are plans to add 1,000 MW of additional natural gas fired combined cycle generation, which will require additional cooling water capacity that must be secured 
before plans can be realized. The total Hines Energy Complex site occupies 8,200 acres, with the generating plant and cooling pond using approximately 1,500 acres. The balance of the property is land formerly mined for phosphate and currently characterized by a gentle rolling topography with intervening depressions, many having converted to wetlands and lakes that occupy former mine pits.

At Hines, the primary sources of cooling water are: a $10 \mathrm{mgd}$ wastewater effluent stream from the City of Bartow, a 1-5 mgd supply of rain water harvested from the tributary watershed, and a makeup water well that can be used only by permit conditions when the cooling pond reservoir drops below a certain water level, such as experienced during the severe drought periods of recent years. The tributary watershed and landscape feeds surface water and some shallow groundwater into the former mine pit lakes and wetlands. Pumps installed in each of these collection systems can be used to transfer water to the cooling pond as water levels reach required levels. All boiler blowdown (600 MW), cooling water, and other plant effluent discharge into the pond, and all water used by the plant is withdrawn from the 1,200-acre pond sourced by the municipal wastewater effluent, the extensive harvesting and storage wetland system, and groundwater pumping during severe drought periods.

Previously, the power plant had plans to recharge the aquifer in the future from expansion of the wetland systems, as shown Figures 13 and 14 below, but this approach has been shelved in recent years due to regulatory concerns with the potential or releasing arsenic from geologic formations in the aquifer. In 2013, Hines completed a large infrastructure project that will allow them to harvest 2 million gallons per day from a now closed phosphate processing facility's gypsum stack approximately 2 miles away. An additional project will allow them to harvest an 4 million gallons per day from an adjacent mine site. 


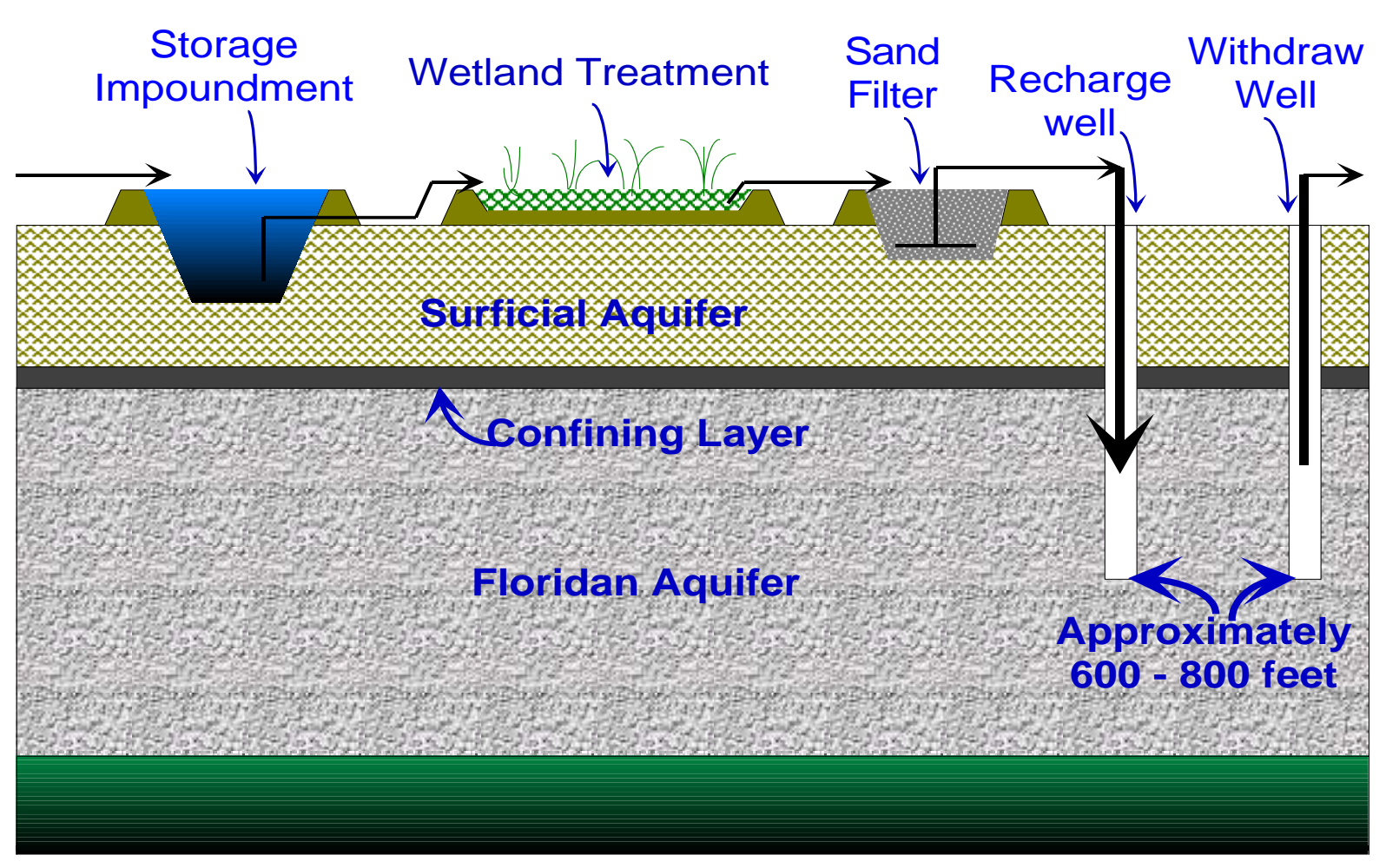

Figure 13. Aquifer recharge concept schematic.

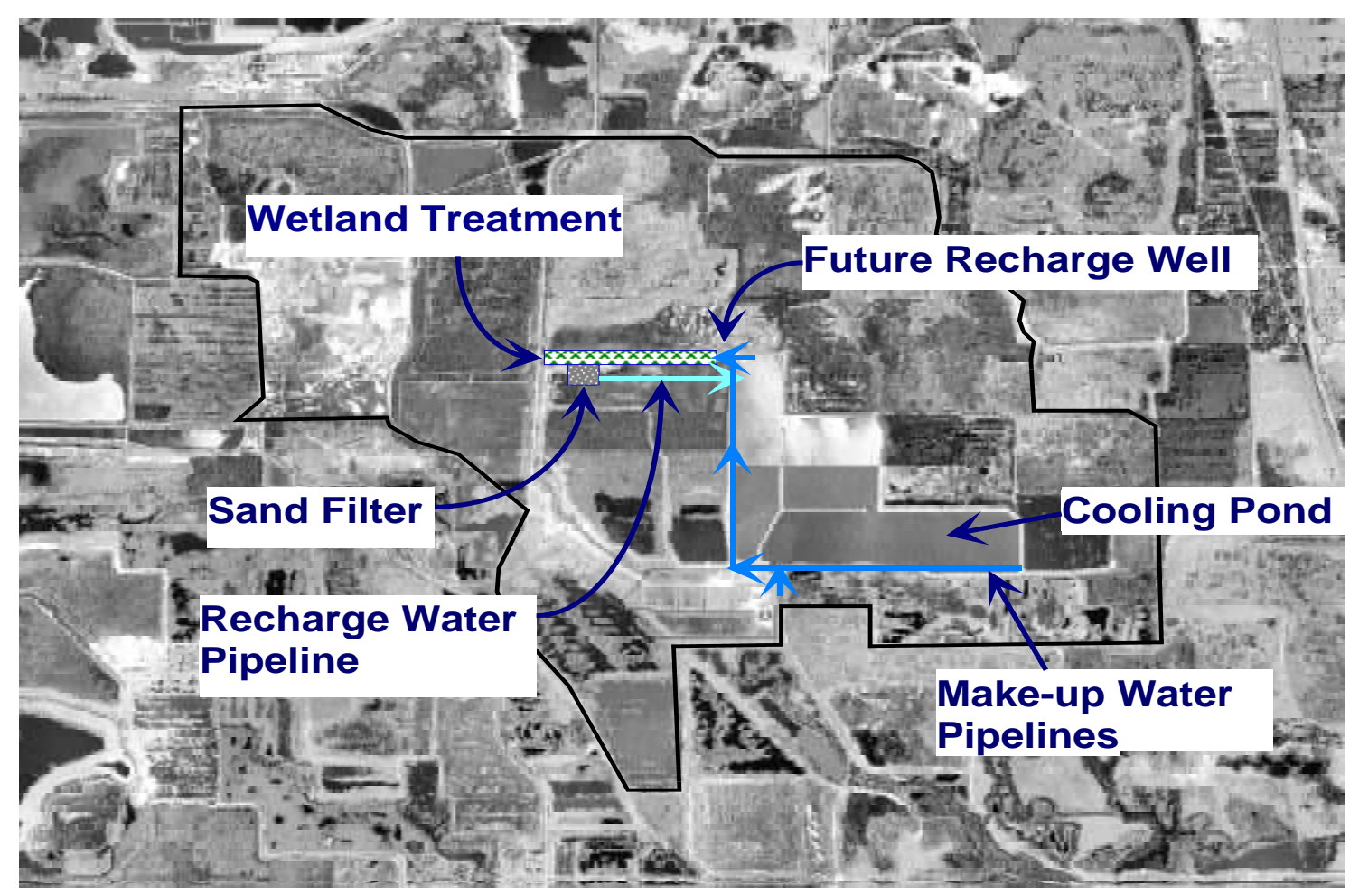

Figure 14. Aquifer recharge concept plan. 


\section{Minnesota Municipal Power Agency (MMPA) - Faribault Energy Park}

MMPA's Faribault Energy Park, located in south-central Minnesota, is an on-demand, natural gas energy production facility. Due to the plant's significant cooling water demands, MMPA wanted to reuse cooling water and collect stormwater runoff to reduce groundwater withdrawals. There was also a desire to provide passive recreational activities in a natural setting for visitors and the community. A wetland park system was designed and installed, resulting in three surface-flow wetlands that flow into a storage basin where water is withdrawn for the cooling towers. The wetlands collect water from an agricultural ditch system draining approximately 500 acres of commercial land, from the site storm water runoff, and groundwater. The design of the wetlands includes both shallow and deep water areas. The shallow zones provide conditions for emergent vegetation which can treat contaminants and feces from the resident waterfowl. Deeper zones increase the storage potential and provide winter refuge for the resident fish population. The project has resulted in reduced groundwater pumping as well as reduced discharge of salt-laden blowdown water to a nearby ditch.

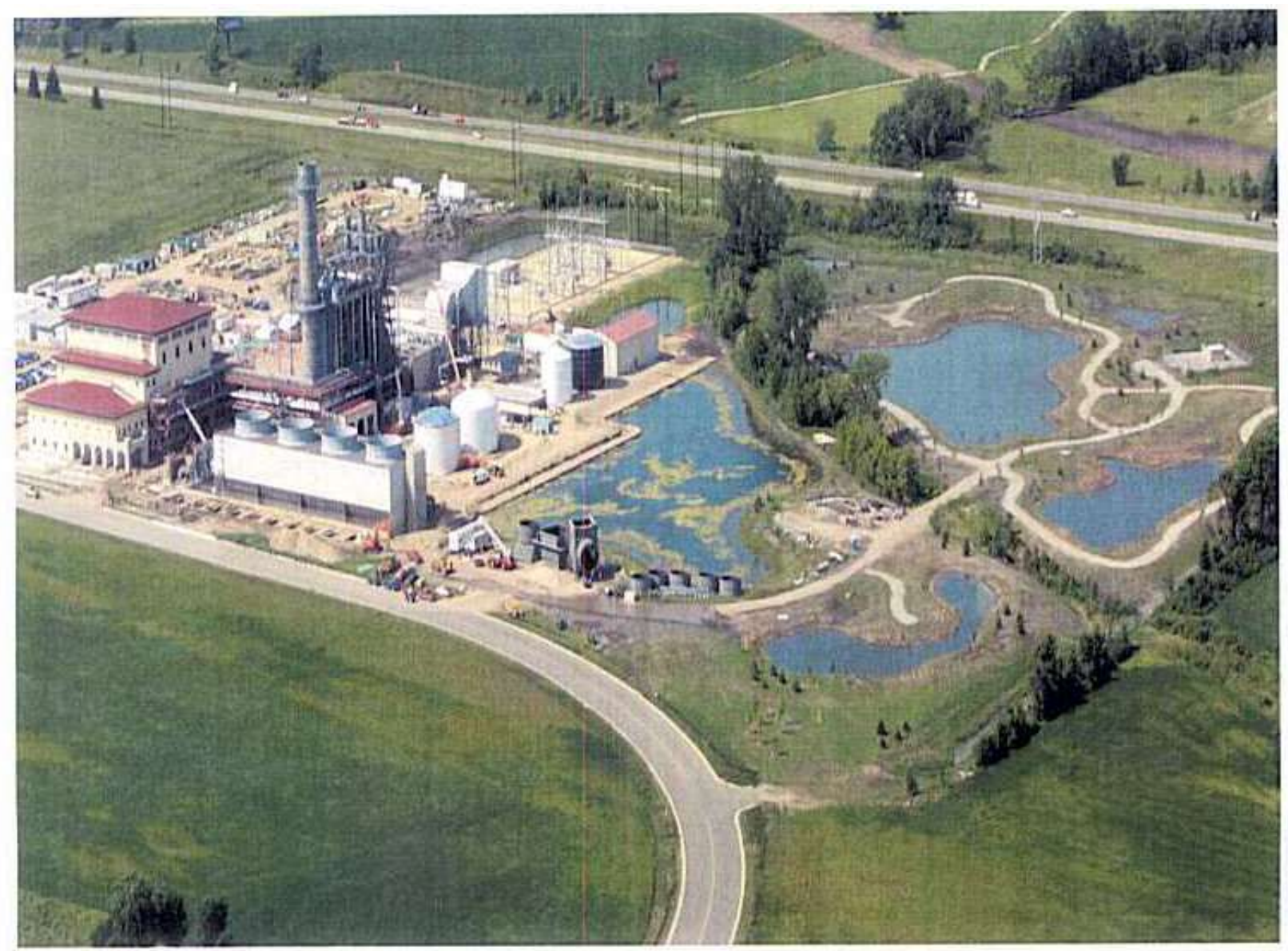

Source: MMPA, 2007.

Figure 15. MMPA Faribault Energy Park Constructed Wetlands. 


\section{SaskPower Constructed Wetland}

In 1994, SaskPower built an 80-acre constructed wetland to provide cooling water to its Shand Power Station in Saskatchewan, Canada. This wetland provides up to 40 percent of the station's annual cooling water requirements. The wetland consists of two main cells, which are divided into subcells with several waterflow paths. Cattails and bulrush are the dominant wetland species responsible for filtering and purifying the treatment effluent. The wetland is surrounded by a soil dike to contain the water. In addition, it receives and purifies the City of Etevan's secondary sewage wastewater, eliminating the need for semi-annual releases of the Etevan lagoons to the environment. The wetland is capable of reducing nutrients, suspended solids, biochemical oxygen demand, heavy metals, bacteria and viruses by 70 to 95 percent. Adjacent to the wetland is a 290-acre duck pond, providing a marsh habitat for various wildlife and migrating waterflowl to nest each spring (SaskPower, 2003).
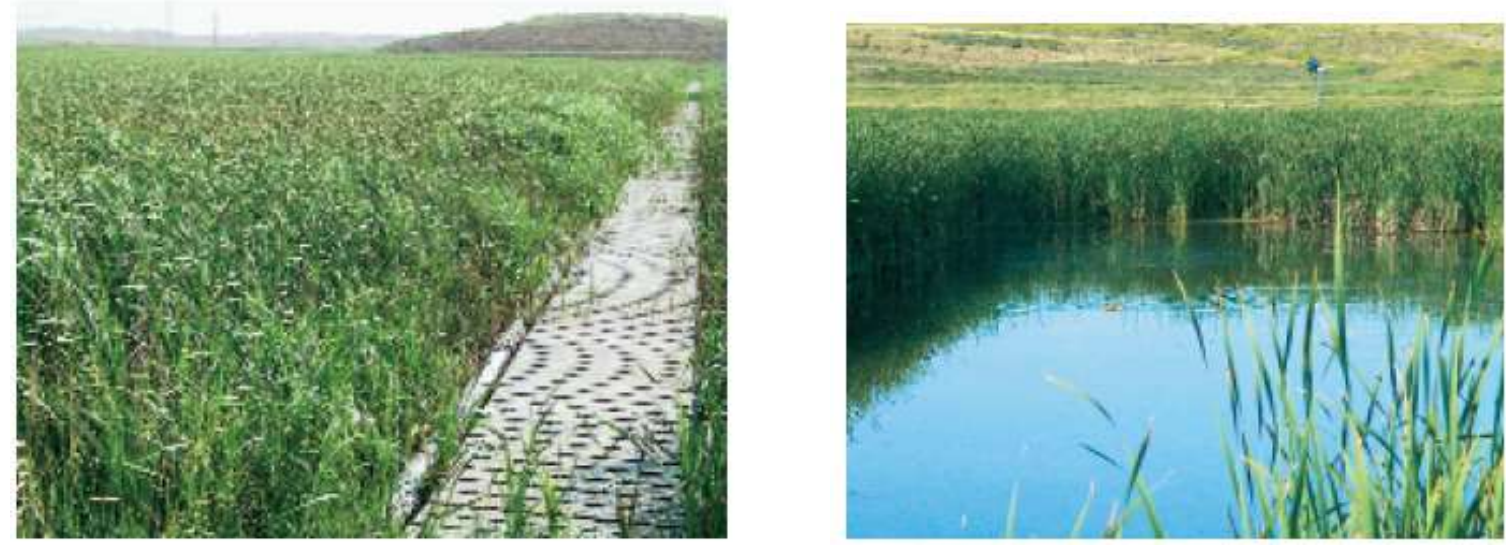

Source: SaskPower, 2003.

Figure 16. Images of the SaskPower Constructed Wetland and Duck Marsh. 


\section{CHAPTER 5 - WETLANDS WATER COOLING - EVALUATION MODEL}

Following literature review of industry and ecological issues, and evaluation of design and operating issues in power plant cooling systems, the AES/SES Team developed a comprehensive, dynamic model to simulate a power plant cooling cycle comparing both conventional cooling systems and a constructed wetland-based system to supplement a conventional water supply and cooling system. To accomplish this, the Team first developed the equations and algorithms for typical power plant water and heat balances capable of accurately calculating the relationships between power plant production, heat generation (and removal required), water use (volume), and impact of temperatures. The algorithms were also developed to model the heat and water balances of wetland systems of various designs and capacities. This enables evaluation of the impact of wetland cooling and makeup integration from $0 \%$ all the way to $100 \%$ effective when compared with conventional systems.

To establish the model and base case foundation for the study, the Team utilized documented studies of 500-600 MW power plant systems with both open (oncethrough) and closed loop (circulating) cooling, providing average flow, temperature and performance characteristics. A database of hourly power plant operating data for all plants throughout the U.S. was also established (available via USEPA). The hourly data was correlated with DOE/EIA databases which have power plant design, cooling system, water source, permit, and production data to generate a comprehensive database with power plant design and water system information combined with hourly MWh generated, fuel input in mmBtu, tons emissions, and a calculated unit heat rate. With this simulation model and power plant operating database, it is possible to compare a range of alternative cooling system cases. It is important to note that the simulation is not a 'static' simulation, but a dynamic simulation using 1-4 hour operating data sets that use actual thermal power plant historical data, combined with design data for either once-through or closed loop cooling systems. This model has been used to scale and compare the performance and the impacts of alternative cases to evaluate a 'status quo' system as it exists, and scale it up so the wetland-based system provides from $0 \%$ to $100 \%$ of the cooling, with the model outputs describing the size and conditions of the wetland-based alternative system required to accommodate the equivalent cooling capacity (including water use and capacity).

\section{Modeling Overview}

STELLA ${ }^{T M}$ is a commercial software package that allows the user to model complex dynamic systems processes through mathematical relationships. The software has a graphical user interface that can accept variable user input and can display model output via numerical readouts, tables, and graphs.

For this work, a STELLA ${ }^{\mathrm{TM}}$-based model has been built to continuously simulate the function and performance of a series of constructed wetlands used for cooling and 
recycling power plant process water. The model contains components representing the power plant water and heat flows, wetland water quantity and temperature, and ancillary other water inputs. The purpose of the model is to match required cooling wetland size to power plant capacity and operational cycles, and to incorporate permit restrictions on cooling source water availability.

The model simulates thermal flux between the wetland water and wetland bottom sediments, but does not simulate water volume exchange or groundwater flow. Depending on the site-specific conditions, the flow of groundwater could be in or out of the wetland. This functionality may be revisited during the pilot project phase.

To demonstrate the concept applicability of constructed cooling wetlands, a demonstration, non-site specific, model has been developed. Many of the model inputs are location dependent; the demonstration model uses data from the Midwest, including climatic and power plant operational information from the Chicago region and river source water characteristics from the Mississippi River.

\section{Modeling Methodology}

\section{Model Description}

The model contains components representing the general heat flow of a power plant, the water flow and heat transfer of a series of constructed cooling wetland cells and its source water (Figure 17). Additional model components are used to compare the results from the power plant/constructed wetland system to a natural (ambient) wetland, (i.e. one that is similar to the cooling wetland but does not receive water from the power plant), and a cooling tower. 


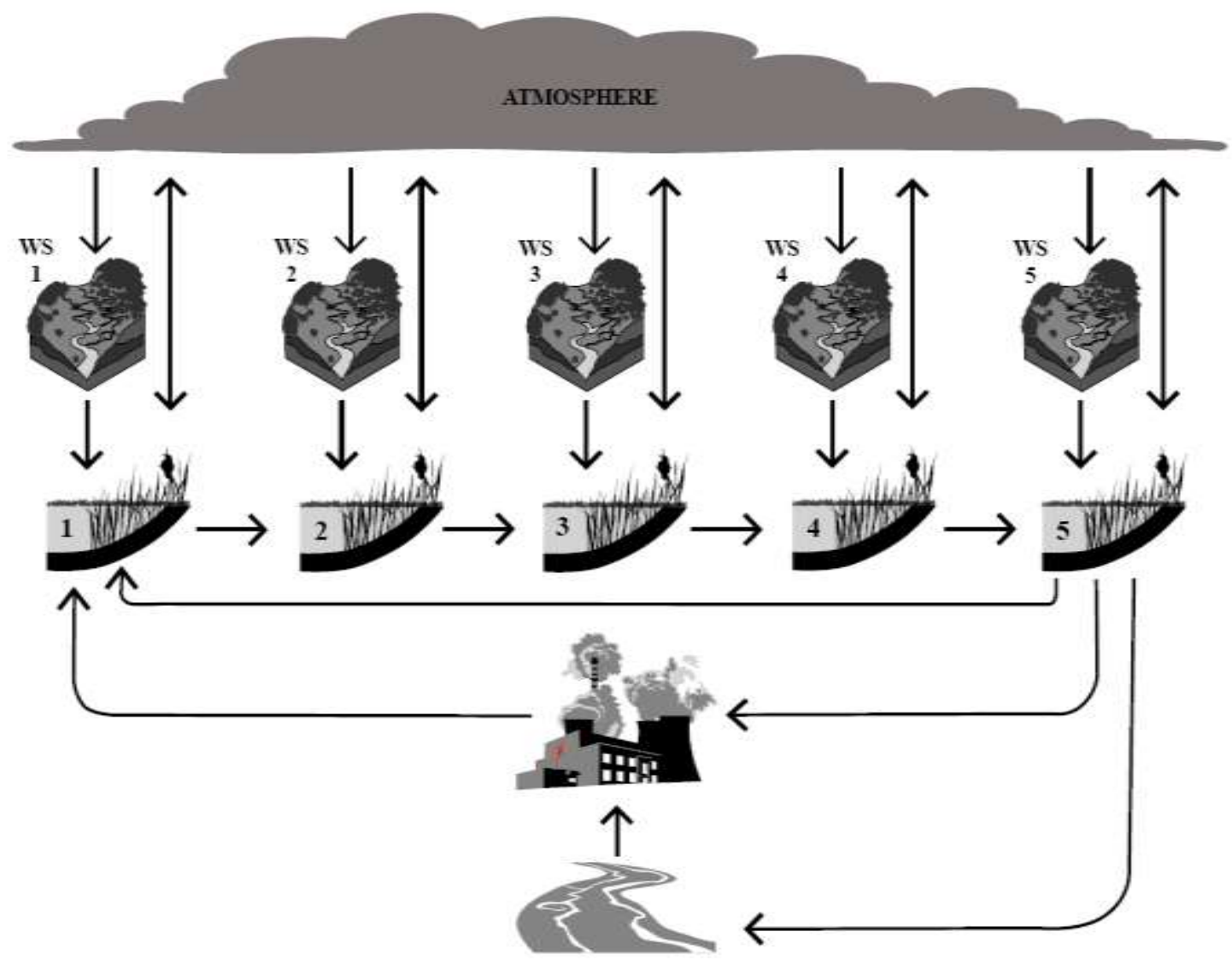

Figure 17. System water and heat flow diagram.

The model uses time series input values with a 4-hour time step. The model equations are integrated as first order equations with a user-defined $\Delta \mathrm{t}$ (time step). Results are output every 4 hours.

\section{$\underline{\text { Power Plant }}$}

The model can simulate the heat flows and water requirements of a once-through or closed loop steam fossil-fuel power plant. Flexibility is built into the model to allow modifications to the type of the power plant in the future.

The power plant capacity can be varied by the model user. This value is reduced to an actual operations value using data from a typical year (with operations data from the Joliet power plant near Chicago used for initial model demonstration). These values and an assumed heat to power value of $3,413 \mathrm{BTU} / \mathrm{kWh}$ are used to calculate the amount of heat in btu used in power production.

Heat to power $=3413(B T U / k W h)$ * plant capacity $(M W){ }^{*} 1000(\mathrm{kWh} / \mathrm{MWh}){ }^{*} 4$ (hour) * power plant operation as a fraction of overall plant capacity 
The plant capacity and an assumed heat requirement of $10,000 \mathrm{BTU} / \mathrm{kWh}$ for a steam fossil-fuel power plant are used to determine the total heat input to the boiler.

Total heat input $=10,000(B T U / \mathrm{kWh}){ }^{*} 1000(\mathrm{kWh} / \mathrm{MWh}){ }^{*}$ plant capacity $(\mathrm{MW})$ * 4 (hour) * power plant operation as a fraction of overall plant capacity

Assuming a modern boiler fuel to steam efficiency of $86 \%$, (Schilling, 2005) the amount of heat to steam is calculated.

Heat to steam $=$ total heat input $(B T U){ }^{*}$ boiler efficiency

From this, the amount of heat rejection, or the heat in the steam to be removed in the condenser, can be calculated.

Heat rejection $=$ heat to steam $(B T U)-$ heat to power $(B T U)$

Cooling water inflow to the condenser can be adjusted depending on the scenario being modeled. The model is set up to use a mix composed of a variable permitted quantity of flow from a river and flow from the last wetland cell. Water withdrawn from the wetland can be used to provide cooling water supply when the required cooling water flow rate exceeds the permitted river water withdrawal rate. The permitted withdrawal rate is a value that can be modified depending on the location of the plant and the local regulations down to a value of zero withdrawal. The temperature of the stream water is a user-defined time series.

Condenser cooling water in = permitted stream withdrawal + wetland withdrawal

Condenser cooling water heat in $=$ stream withdrawal heat $(B T U)+$ wetland withdrawal heat (BTU)

The outflow water rate leaving the condenser is assumed to be equal to the condenser water inflow rate. Inflow water heat and heat rejection is equal to outflow heat. The outflow water and heat flows into the first wetland cell.

\section{Wetland}

The constructed cooling wetland is modeled as a series of five interconnected cells that are assumed to be well-mixed (i.e., no thermal stratification). For modeling purposes, the number of cells selected was chosen to allow for topographic differences in the application sites, use of differing wetland design characteristics in a wetland complex, and evaluation of ecological characteristics as temperatures changed through the wetland series. Each wetland cell exchanges water and heat from the upstream to the downstream wetland cells (or power plant or river), runoff from the wetland cell's contributing watershed, and precipitation falling directly on the wetland cell. In addition heat is exchanged with the atmosphere through solar radiation, long-wave radiation, back radiation, evaporation, and conduction (Figure 18). 


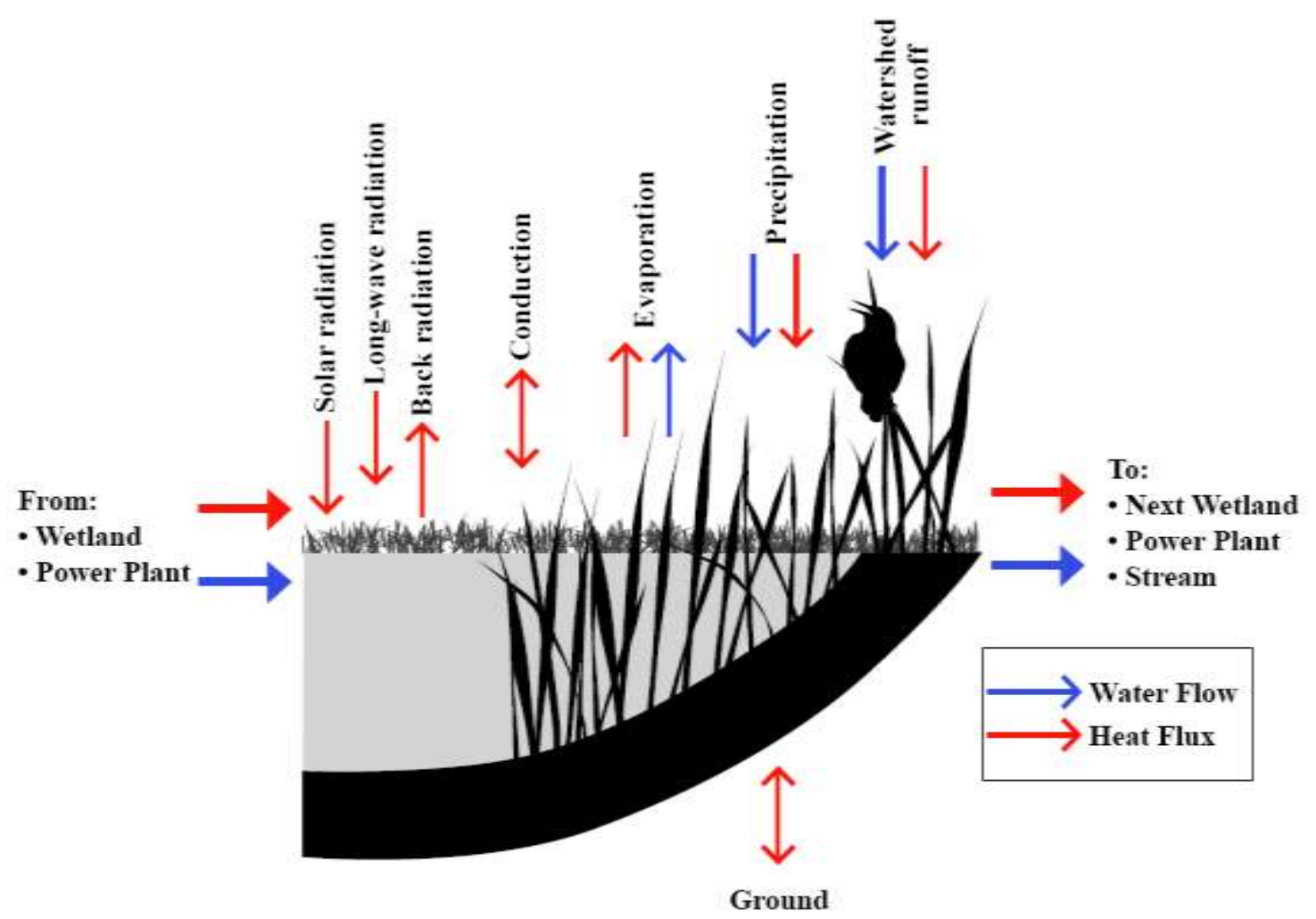

Figure 18. Wetland heat and water flow.

Various climatic time series inputs are incorporated into the model: relative humidity, air temperature, solar radiation, atmospheric pressure, wind speed, air dew point temperature, and precipitation. Hourly data for all but precipitation are readily available from the National Renewable Energy Laboratory's TMY2 data base with data from Chicago being used in the demonstration model. The hourly values were averaged using a running average to obtain 4-hour values. Hourly precipitation data were obtained from the NOAA co-op station \#11 1549 Chicago O'Hare. Hourly precipitation values were summed over four 1 -hour periods to obtain the 4-hour model input time series.

The watershed area contributing surface water runoff to each wetland cell is userdefined to be from 3 to 25 times the wetland area. The volume of runoff from the watershed delivered to the wetland is calculated using the TR-55, curve number method (.USDA-NRCS, 1986). 
Watershed unit surface water runoff $=\frac{(P-0.2 S)^{2}}{(P+0.8 S)}$

where

$\mathrm{P}=$ precipitation

$S=\frac{10 O Q}{C N}$, potential maximum retention after runoff begins

$\mathrm{CN}=$ user-defined curve number (78 is assumed in the generic model)

The temperature of the runoff is assumed to be equal to the air dew point temperature, which is input to the model as a time series of measured values.

Additional heat inputs to the wetland include direct short wave solar radiation, atmospheric long wave radiation, and conduction. Measured short wave solar radiation from the TMY2 dataset is input to the model as a time series. Atmospheric long wave radiation is calculated based on equations in French/McCutheon's Water Quality Modeling: Transport \& Surface Exchange in Rivers (1989).

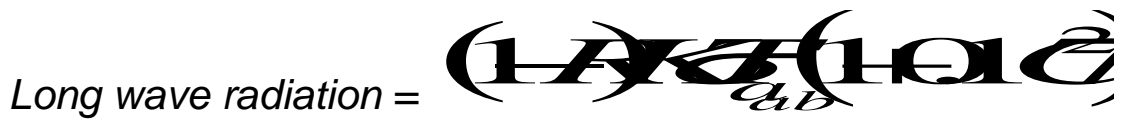

where

$R=$ reflectivity, typically 0.03

$K=$ constant, $2.89 \times 10^{-6}$

$\sigma=$ Stefan-Boltzmann constant, $4.15 \times 10^{-8} \mathrm{BTU} \mathrm{ft}^{-2}$ day $^{-1}\left({ }^{\circ} \mathrm{R}\right)^{-4}$

$T_{a}=$ absolute air temperature $\left({ }^{\circ} \mathrm{R}\right)$

$C=$ cloudiness factor (derived from data from the International Satellite Cloud Climatology Project, Anderson 2009)

Conduction processes can transfer heat to and from the wetland water to the air. The equation used in the model is based on Ryan et al., 1974.

$$
\text { Conduction flux = evaporation flux } \times \frac{\left(\left(T_{s}-T_{a}\right)\right.}{e_{s}-e_{a}}
$$

where

$$
\begin{aligned}
& C=\text { constant of } 0.26 \mathrm{mmHg}\left({ }^{\circ} \mathrm{F}\right)^{-1} \\
& T_{s}=\text { water temperature } \\
& T_{a}=\text { air temperature } \\
& e_{s}=\text { water vapor pressure } \\
& e_{a}=\text { air vapor pressure }
\end{aligned}
$$


Wetland cells \#1 through \#4 lose water and heat to evaporation and to the downstream wetland cell, and wetland cell \#5 loses water and heat to evaporation and the river or power plant. Additional heat can be lost to back radiation and lost (or gained) by the underlying wetland soils and conduction. The evaporation flux is calculated based on the equation in Ryan et al. 1974.

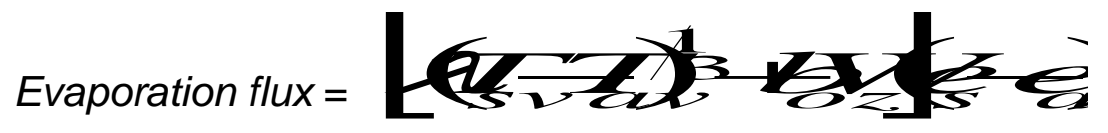

where

$$
\begin{aligned}
& \lambda=\text { constant equal to } 22.4 \mathrm{Btu}_{\mathrm{ft}}^{-2} \mathrm{day}^{-1} \mathrm{mmHg}^{-1}\left({ }^{\circ} \mathrm{F}\right)^{-1 / 3} \\
& T_{s v}=\text { virtual temperature of water surface } \\
& T_{a v}=\text { virtual temperature of air } \\
& b_{o}=\text { constant of } 14 \mathrm{Btu} \mathrm{ft}^{-2} \mathrm{day}^{-1} \mathrm{mmHg}^{-1}\left(\mathrm{mi} \mathrm{hr}^{-1}\right)^{-1} \\
& W_{z}=\text { wind speed }(\mathrm{mph}) \\
& e_{s}=\text { water vapor pressure } \\
& e_{a}=\text { air vapor pressure }
\end{aligned}
$$

The back radiation heat flux is given in Ryan et al. 1974 .

$$
\text { Back radiation heat flux }=\varepsilon \sigma T_{s}^{4}
$$

where

$$
\begin{aligned}
& \mathcal{E}=\text { surface emissivity } \\
& \sigma=\text { Stefan-Boltzmann constant, } 4.15 \times 10^{-8} \mathrm{Btu} \mathrm{ft}^{-2} \text { day }^{-1}\left({ }^{\circ} \mathrm{R}\right)^{-4} \\
& T_{s}=\text { absolute water surface temperature }
\end{aligned}
$$

The heat flux between the underlying wetland sediments and water is calculated using the formula employed in the model QUAL2K (Chapra, et al., 2007).

\footnotetext{
Sediment-water heat flux $=15$ where

$\rho_{s} C_{p s}=$ density of sediments multiplied by the specific heat of the sediments $0.550 \mathrm{cal} / \mathrm{cm}^{3}{ }^{\circ} \mathrm{C}$ for lake, gelatinous sediments* $\alpha_{s}=$ sediment thermal diffusivity, $0.0033 \mathrm{~cm}^{2} / \mathrm{s}$, for lake, soft sediments ${ }^{*}$ $H_{\text {sed }}=$ effective thickness of the sediment layer, assumed to be $12 \mathrm{~cm}$ $T_{s}=$ temperature of the sediment
} 
$T_{w}=$ temperature of water

* as given in Table 4 of the QUAL2K documentation (Chapra, et al., 2007).

The user defined inputs to the model are shown in Table 8.

Table 8. Model user inputs.

\begin{tabular}{|l|l|l|}
\hline Name & Units & Description \\
\hline plant capacity & MW & power plant capacity \\
\hline watershed CN & -- & curve number \\
\hline wetland 1 area acres & acre & surface area of wetland cell 1 \\
\hline wetland 2 area acres & acre & surface area of wetland cell 2 \\
\hline wetland 3 area acres & acre & surface area of wetland cell 3 \\
\hline wetland 4 area acres & acre & surface area of wetland cell 4 \\
\hline wetland 5 area acres & acre & surface area of wetland cell 5 \\
\hline wetland 1 initial depth & feet & initial depth of wetland cell 1 \\
\hline wetland 2 initial depth & feet & initial depth of wetland cell 2 \\
\hline wetland 3 initial depth & feet & initial depth of wetland cell 3 \\
\hline wetland 4 initial depth & feet & initial depth of wetland cell 4 \\
\hline wetland 5 initial depth & feet & initial depth of wetland cell 5 \\
\hline permit flow rate & cfs & permitted water withdrawal rate \\
\hline permit water temp & ${ }^{\circ} \mathrm{F}$ & permitted temperature of replacement water \\
\hline watershed to wetland area conversion & -- & multiplied by wetland area to give area of \\
& & contributing watershed \\
\hline precipitation & inches & observed data for specific location \\
\hline air dew point temp & ${ }^{\circ} \mathrm{F}$ & observed data for specific location \\
\hline atmospheric pressure & $\mathrm{mmHg}$ & observed data for specific location \\
\hline wind speed & $\mathrm{mph}$ & observed data for specific location \\
\hline relative humidity & $\%$ & observed data for specific location \\
\hline air temp & ${ }^{\circ} \mathrm{F}$ & observed data for specific location \\
\hline solar radiation & Btu/ft & observed data for specific location \\
\hline
\end{tabular}

\section{Model Quality Control}

Because of the complexity and size of this model (over 230 inputs, variables and outputs), a detailed review of the model workings was completed. The formulations and units of all calculations were confirmed against the original source reference and were verified for consistency throughout the model. Additionally, some basic model tests were run (e.g., zero power plant input to wetlands, constant inputs to wetlands) that verified the consistency of model formulations. This was particularly important since the model is broken into five wetland cells that, given the same inputs, should respond identically. 


\section{Preliminary Model Verification}

Evaporation is the major player in determining the energy budget of the wetlands and the total water lost from the system; therefore, it was important to verify that the model was producing reasonable values. Without actual wetland evaporation data to verify the model (the model is not representative of any existing site), average annual and summer (May-Oct) pan evaporation data was obtained from the NOAA Technical Report NWS 33: Evaporation Atlas for the Contiguous 48 United States and from NWS Co-op weather station data for two Illinois locations (Hennepin and Urbana). This data indicated that the annual evaporation amount from open water in the Chicago region was around 35 inches with the majority of that (25 inches) occurring from May to October. These values were compared to the evaporation amount occurring in the ambient (no power plant connection) wetland and represent natural evaporation from the wetland surface.

By performing this verification it was discovered that the original assumptions of no reflection of incoming solar radiation and negligible cloud cover (in the long wave radiation calculation) were not valid. According to Adams et al. (1987), a reasonable assumption of reflection of incoming solar radiation is $6 \%$. Additionally, average monthly cloud cover information for the Chicago region was obtained from data derived from the International Satellite Cloud Climatology Project (Anderson, 2009) and applied in the long wave radiation calculation. These modifications combined to yield an annual evaporation amount of 37 inches, with 22 inches occurring from May to October. These values are deemed acceptable for the demonstration model runs. Further calibration of the model will occur when it is applied to the pilot project sites with measured data.

\section{Results}

\section{Scenario Descriptions}

The purpose of the demonstration model is to continuously simulate the function and performance of a constructed wetland system used for cooling, supplying, or recycling power plant process water. To demonstrate this, Scenario 1 simulates water withdrawal only to supply the makeup water for a typical cooling tower. Scenario 2 simulates wetland cooling of water coming from a typical once-through system before it is released back into a river, essentially acting as a temperature buffer between the power plant and the river. Scenario 3 simulates a closed-loop system where heated water from the power plant is released into wetland cell \#1 and is supplied from wetland cell \#5. These example simulations demonstrate the feasibility of using the various capacities of constructed wetlands to reduce or eliminate the amount used from, or impact to, existing surface water features.

Several variables were modified in the scenarios; they include plant capacity, wetland area, watershed to wetland area ratio, and precipitation amount. The variable permutations are summarized in Table 9. 
Table 9. Model Variable Permutations.

\begin{tabular}{|l|l|l|}
\hline Variable & Modeled Values & Units \\
\hline Plant Capacity & $25,100,300,500$ & MW \\
\hline Wetland Area & $100,500,1000,5000$ & acres \\
\hline $\begin{array}{l}\text { Watershed to } \\
\text { Wetland Area Ratio }\end{array}$ & $3,10,25$ & -- \\
\hline Precipitation year & $1996($ dry), 1984 (average) & -- \\
\hline
\end{tabular}

\section{Scenario 1: Makeup Water Supply}

For this scenario, the wetland is intended to harvest water from direct precipitation and watershed runoff and simply act as a source of water to replace that which is lost from a donor water source (e.g., river) via cooling tower evaporation and blowdown for an entire year (Figure 19). The value used to represent the amount of evaporation from a typical cooling tower was $480 \mathrm{gal} / \mathrm{MWh}$, which is representative of actual power plants (EPRI, 2002). For each model time step, this same amount of water was transferred from the wetland system back to the river. Each wetland cell is modeled with an initial average depth of $3 \mathrm{ft}$.

In this scenario, model realizations are run to define the variable combinations (cases) that result in adequate water available within the wetland to satisfy the makeup water needs. If there is not an adequate supply, the wetland will dry out, and the power plant would have to use an alternate source supply for makeup water. 


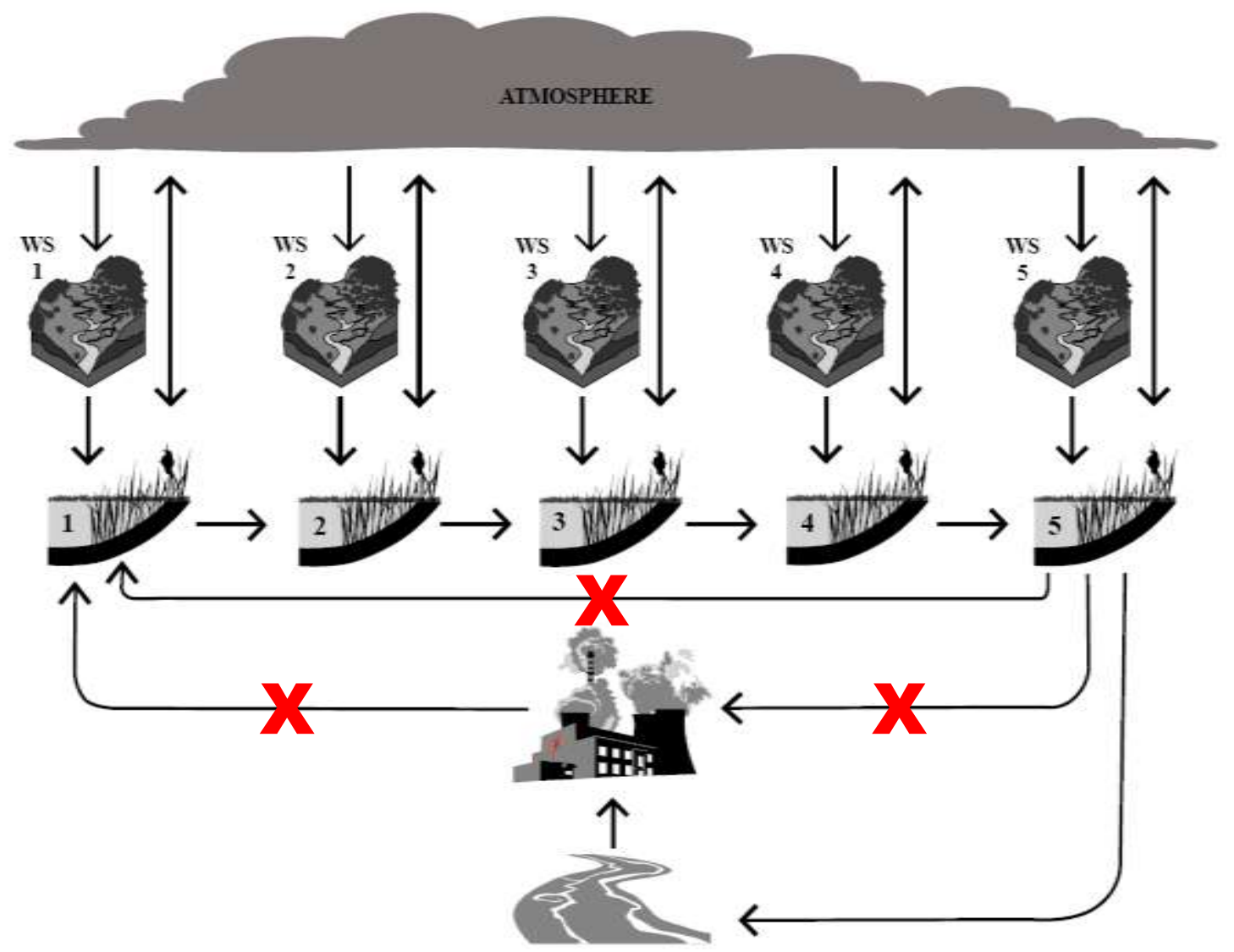

Figure 19. Scenario 1 diagram (red X's indicate those paths that are not active in the current scenario).

\section{Scenario 1: Results}

For the dry year (1996), 19 of the 48 Scenario 1 variable permutations (cases) resulted in the wetland system drying out completely. Therefore, under those conditions, the wetland is not able to satisfy the makeup water needs for the entire year, so some makeup water would need to be drawn from the source/receiving water body to provide the necessary makeup water. In addition, 22 of the 48 cases resulted in an overall deficit of water from the wetland at the end of the year, even though it did not completely dry out. Only 7 cases (all with a watershed to wetland area ratio of 25:1) resulted in an overall increase in water volume in the wetland.

Results for the average rainfall year (1984) were similar to the dry year with a few exceptions. The wetland dried out in 16 of the 48 cases, was below the initial water depth (but not dry) in 15 cases, and was above the initial level in 17 cases.

Tables 10 and 11 show the final water depths in the wetland for the dry and average precipitation years. 
Tables 10 and 11. End of year wetland water depth for dry and average rainfall years $(R E D=$ dry out; YELLOW = less than initial depth $(3 \mathrm{ft})$; GREEN = greater than or equal to initial depth (3ft)).

\begin{tabular}{|l|c|c|c|}
\hline \multicolumn{4}{|c|}{ FINAL WETLAND DEPTH (FT) } \\
\hline PRECIP YEAR & 1996 & (Dry) & \\
\hline Wetland Area & \multicolumn{3}{|c|}{ WS to WL Ratio } \\
\hline Plant Capacity & 3 & 10 & 25 \\
\hline 100 Acre & & & \\
\hline $25 \mathrm{MW}$ & 0.1 & 0.8 & 2.0 \\
\hline $100 \mathrm{MW}$ & 0.0 & 0.0 & 0.0 \\
\hline $300 \mathrm{MW}$ & 0.0 & 0.0 & 0.0 \\
\hline $500 \mathrm{MW}$ & 0.0 & 0.0 & 0.0 \\
\hline $500 \mathrm{Acre}$ & & & \\
\hline $25 \mathrm{MW}$ & 1.8 & 2.4 & 3.6 \\
\hline $100 \mathrm{MW}$ & 0.5 & 1.2 & 2.4 \\
\hline $300 \mathrm{MW}$ & 0.0 & 0.0 & 0.0 \\
\hline $500 \mathrm{MW}$ & 0.0 & 0.0 & 0.0 \\
\hline $1000 \mathrm{Acre}$ & & & 3.0 \\
\hline $25 \mathrm{MW}$ & 2.0 & 2.5 & 3.8 \\
\hline $100 \mathrm{MW}$ & 1.4 & 2.0 & 3.2 \\
\hline $300 \mathrm{MW}$ & 0.0 & 0.3 & 1.6 \\
\hline $500 \mathrm{MW}$ & 0.0 & 0.0 & 0.0 \\
\hline $5000 \mathrm{Acre}$ & & & 3.5 \\
\hline $25 \mathrm{MW}$ & 2.1 & 2.7 & 4.0 \\
\hline $100 \mathrm{MW}$ & 2.0 & 2.6 & 3.3 \\
\hline $300 \mathrm{MW}$ & 1.7 & 2.3 & \\
\hline $500 \mathrm{MW}$ & 1.4 & 2.0 & 3 \\
\hline
\end{tabular}

\begin{tabular}{|c|c|c|c|}
\hline \multicolumn{4}{|c|}{ FINAL WETLAND DEPTH (FT) } \\
\hline PRECIP YEAR & 1984 & (Average) & \\
\hline Wetland Area & \multicolumn{3}{|c|}{ WS to WL Ratio } \\
\hline Plant Capacity & 3 & 10 & 25 \\
\hline \multicolumn{4}{|l|}{100 Acre } \\
\hline $25 \mathrm{MW}$ & 1.0 & 1.8 & 3.6 \\
\hline $100 \mathrm{MW}$ & 0.0 & 0.0 & 0.0 \\
\hline $300 \mathrm{MW}$ & 0.0 & 0.0 & 0.0 \\
\hline $500 \mathrm{MW}$ & 0.0 & 0.0 & 0.0 \\
\hline \multicolumn{4}{|l|}{500 Acre } \\
\hline $25 \mathrm{MW}$ & 2.6 & 3.4 & 5.2 \\
\hline $100 \mathrm{MW}$ & 1.4 & 2.2 & 4.0 \\
\hline $300 \mathrm{MW}$ & 0.0 & 0.0 & 0.8 \\
\hline $500 \mathrm{MW}$ & 0.0 & 0.0 & 0.0 \\
\hline \multicolumn{4}{|l|}{1000 Acre } \\
\hline $25 \mathrm{MW}$ & 2.8 & 3.6 & 5.4 \\
\hline $100 \mathrm{MW}$ & 2.2 & 3.0 & 4.8 \\
\hline $300 \mathrm{MW}$ & 0.6 & 1.4 & 3.2 \\
\hline $500 \mathrm{MW}$ & 0.0 & 0.0 & 1.6 \\
\hline \multicolumn{4}{|l|}{5000 Acre } \\
\hline $25 \mathrm{MW}$ & 3.0 & 3.8 & 5.5 \\
\hline $100 \mathrm{MW}$ & 2.8 & 3.7 & 5.4 \\
\hline $300 \mathrm{MW}$ & 2.5 & 3.3 & 5.1 \\
\hline $500 \mathrm{MW}$ & 2.2 & 3.0 & 4.8 \\
\hline
\end{tabular}

The wetland area required to provide the necessary makeup water for an average precipitation year, a watershed to wetland area ratio of 10:1 (average for natural systems), and climate conditions similar to the Chicago region is shown in Table 12.

Table 12. Wetland area required to supply makeup water for average precipitation year (watershed to wetland area ratio 10:1).

\begin{tabular}{|l|c|}
\hline $\begin{array}{l}\text { Plant } \\
\text { Capacity }\end{array}$ & $\begin{array}{c}\text { Wetland } \\
\text { Area } \\
\text { (acres) }\end{array}$ \\
\hline 25 MW & $\sim 100$ \\
\hline $\mathbf{1 0 0}$ MW & $100-500$ \\
\hline $\mathbf{3 0 0}$ MW & $500-1000$ \\
\hline $\mathbf{5 0 0}$ MW & $1000-5000$ \\
\hline
\end{tabular}




\section{Scenario 2: Cooling once-through Water}

For Scenario 2, the model was set up to simulate the use of the wetland to cool oncethrough water before it is returned to the river to mitigate thermal impact to the body of water (Figure 20). Heated water from the power plant is input to wetland cell \#1. The water then moves through the remaining wetland cells and is discharged from wetland cell \#5 to the river (water only flows in one direction, from 1 to 5). Flow between the wetland cells is set equal to the flow coming in to wetland cell \#1, unless the wetland depth is less than $0.5 \mathrm{ft}$, in which case there is no outflow from the wetland cell until the depth is greater than $0.5 \mathrm{ft}$. This model constraint is used to prevent the wetland cells from drying out due to process water outflow (but subsequent evaporation, especially during drought years, could still result in wetland dry-out). If there is not enough water available in the wetland cells to accommodate the return flow to the river (all cells at or below $0.5 \mathrm{ft}$ ), the volume deficit is summed and reported as an undersized wetland complex. The wetland cells are assumed to be hydraulically disconnected (they do not share a common water surface). As in Scenario 1, each wetland cell receives water from direct precipitation and from runoff from the contributing watershed. Each wetland cell is modeled with an initial average depth of $3 \mathrm{ft}$.

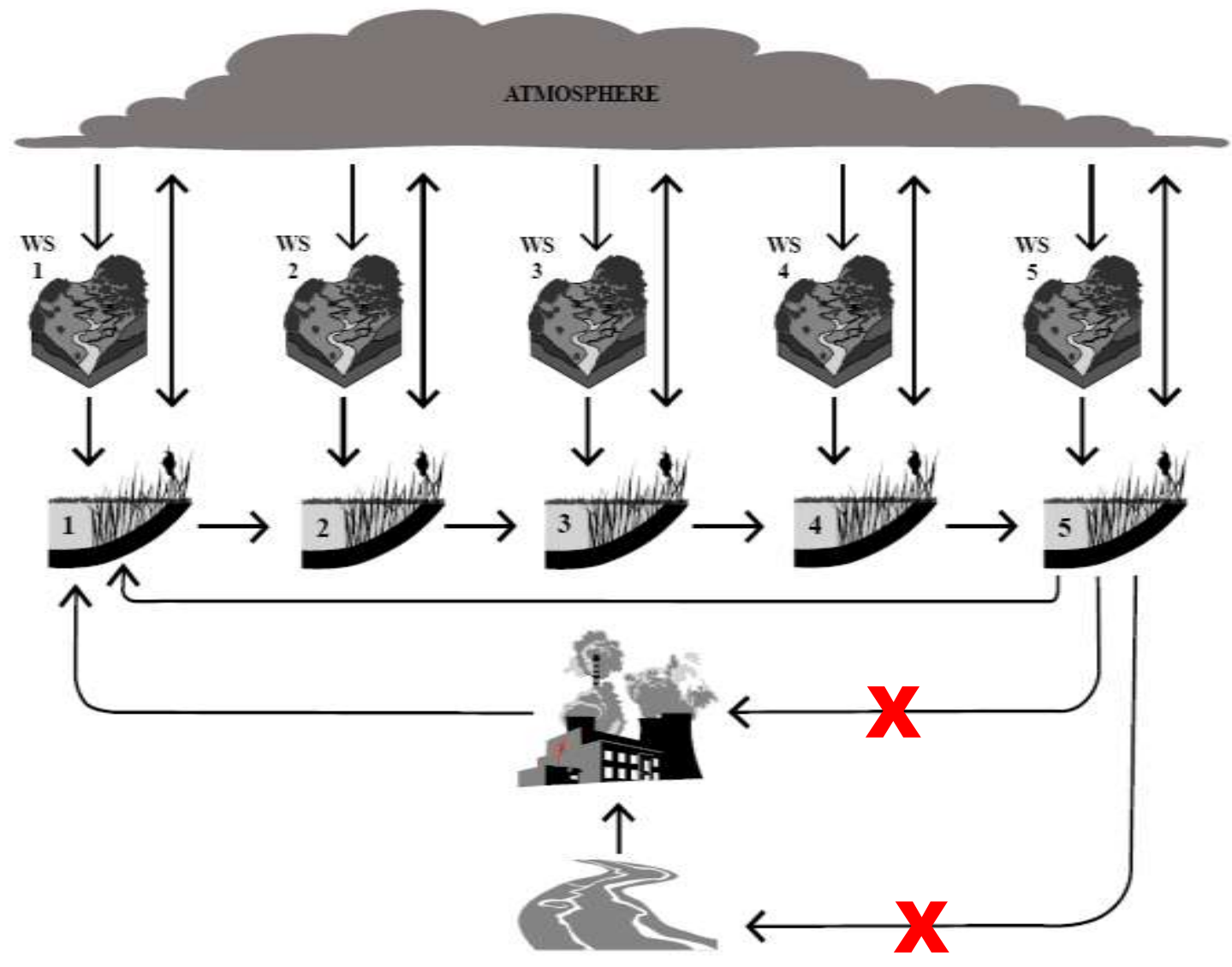

Figure 20. Scenario 2 diagram (red $X$ indicates path is not active in current scenario). 
For this scenario, the model realizations are made to determine model variable combinations that do not result in a deficit to the river and that do not exceed a specified discharge temperature. This maximum temperature is typically stipulated in a power plant's discharge permit.

\section{Scenario 2: Results}

The results for the dry year show that 16 of the 48 cases resulted in a volume deficit in the river (Table 13). Basically, the wetlands did not provide enough water to make up for the amount evaporated (naturally and due to the heated inflow) and maintain a minimum water level. The increased precipitation of the average year only resulted in a deficit in five fewer cases (Table 14). For both years, the watershed to wetland area ratio had minimal affect on the results, thus the significant wetland model parameter was the wetland size.

Tables 13 and 14. Scenario 2 End of Year Surface Water Deficits.

\begin{tabular}{|c|c|c|c|}
\hline \multicolumn{4}{|c|}{ ANNUAL SURFACE WATER DEFICIT (Mgal) } \\
\hline PRECIP YEAR & 1996 & (Dry) & \\
\hline Wetland Area & \multicolumn{3}{|c|}{ Watershed to Wetland Area Ratio } \\
\hline Plant Capacity & 3 & 10 & 25 \\
\hline \multicolumn{4}{|l|}{100 Acre } \\
\hline $25 \mathrm{MW}$ & 0 & 0 & 0 \\
\hline $100 \mathrm{MW}$ & 81 & 61 & 21 \\
\hline $300 \mathrm{MW}$ & 197 & 175 & 137 \\
\hline $500 \mathrm{MW}$ & 248 & 230 & 193 \\
\hline \multicolumn{4}{|l|}{500 Acre } \\
\hline $25 \mathrm{MW}$ & 0 & 0 & 0 \\
\hline $100 \mathrm{MW}$ & 0 & 0 & 0 \\
\hline $300 \mathrm{MW}$ & 182 & 81 & 0 \\
\hline $500 \mathrm{MW}$ & 403 & 304 & 106 \\
\hline \multicolumn{4}{|l|}{1000 Acre } \\
\hline $25 \mathrm{MW}$ & 0 & 0 & 0 \\
\hline $100 \mathrm{MW}$ & 0 & 0 & 0 \\
\hline $300 \mathrm{MW}$ & 0 & 0 & 0 \\
\hline $500 \mathrm{MW}$ & 231 & 33 & 0 \\
\hline \multicolumn{4}{|l|}{5000 Acre } \\
\hline $25 \mathrm{MW}$ & 0 & 0 & 0 \\
\hline $100 \mathrm{MW}$ & 0 & 0 & 0 \\
\hline $300 \mathrm{MW}$ & 0 & 0 & 0 \\
\hline $500 \mathrm{MW}$ & 0 & 0 & 0 \\
\hline
\end{tabular}

\begin{tabular}{|l|c|c|c|}
\hline \multicolumn{5}{|c|}{ ANNUAL SURFACE WATER DEFICIT (Mgal) } \\
\hline PRECIP YEAR & 1984 & \multicolumn{1}{|c|}{ (Average) } & \\
\hline Wetland Area & Watershed to Wetland Area Ratio \\
\hline Plant Capacity & 3 & 10 & 25 \\
\hline $100 \mathrm{Acre}$ & & & \\
\hline $25 \mathrm{MW}$ & 0 & 0 & 0 \\
\hline $100 \mathrm{MW}$ & 52 & 27 & 0 \\
\hline $300 \mathrm{MW}$ & 172 & 142 & 86 \\
\hline $500 \mathrm{MW}$ & 218 & 194 & 135 \\
\hline $500 \mathrm{Acre}$ & & & \\
\hline $25 \mathrm{MW}$ & 0 & 0 & 0 \\
\hline $100 \mathrm{MW}$ & 0 & 0 & 0 \\
\hline $300 \mathrm{MW}$ & 51 & 0 & 0 \\
\hline $500 \mathrm{MW}$ & 262 & 137 & 0 \\
\hline $1000 \mathrm{Acre}$ & & & \\
\hline $25 \mathrm{MW}$ & 0 & 0 & 0 \\
\hline $100 \mathrm{MW}$ & 0 & 0 & 0 \\
\hline $300 \mathrm{MW}$ & 0 & 0 & 0 \\
\hline $500 \mathrm{MW}$ & 0 & 0 & 0 \\
\hline $5000 \mathrm{Acre}$ & & & 0 \\
\hline $25 \mathrm{MW}$ & 0 & 0 & 0 \\
\hline $100 \mathrm{MW}$ & 0 & 0 & 0 \\
\hline $300 \mathrm{MW}$ & 0 & 0 & 0 \\
\hline $500 \mathrm{MW}$ & 0 & 0 & 0 \\
\hline & & & \\
\hline
\end{tabular}

Figures 21 and 22 show the depths for wetland cells \#1 and \#5 over the course of a year for two cases. 
Chapter 5

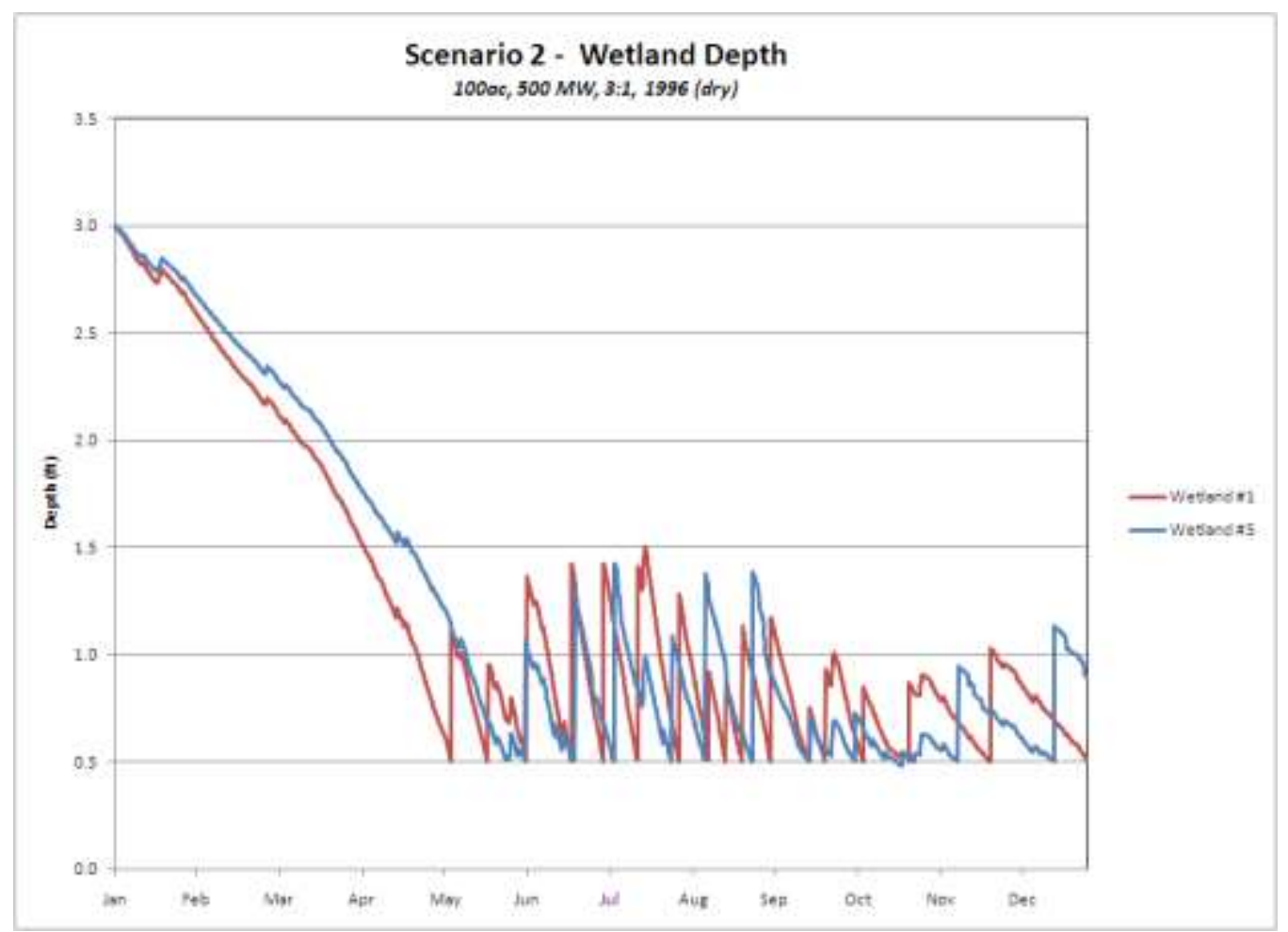

Figure 21. Wetland Depth Change Over One Year for Case with Water Deficit.

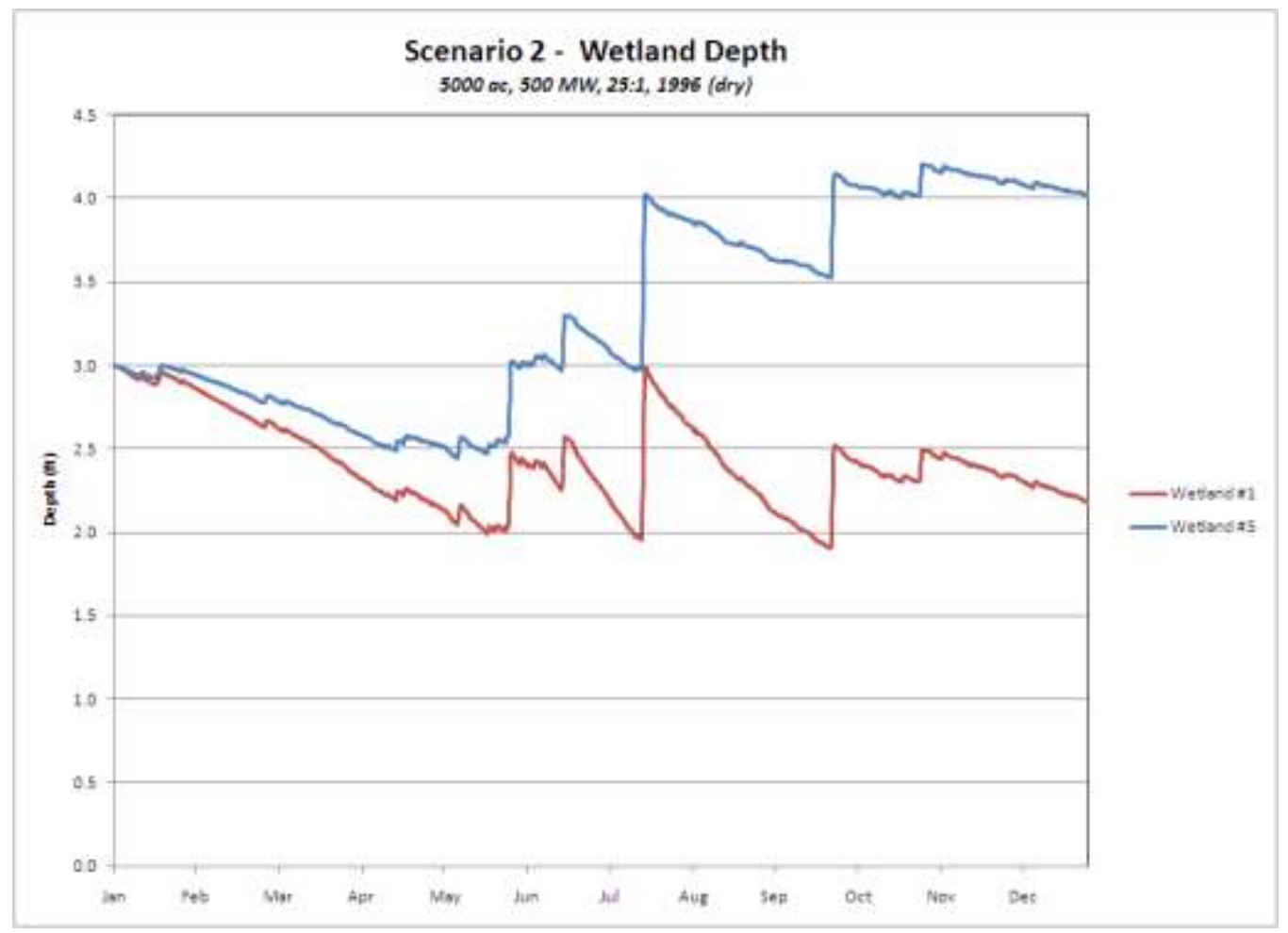

Figure 22. Wetland Depth Change Over One Year for Case with Water Excess. 
These two figures show the variation that is due to changes in wetland size and watershed to wetland area ratio.

Table 15 shows the maximum temperature reached within wetland cell \#5 (the final cell before discharge back to the river) over the year-long simulation. Results are only shown for the dry year because there was very little difference between the dry and average year results. Also, the highest temperatures reached were for those cases where the wetland cells were closest to their minimum depth for the longest time (cases that had a volume deficit). Taking out those results, Table 15 shows that the main factor in the maximum discharge temperature was the watershed to wetland area ratio, and even that had little effect, varying by only $2^{\circ} \mathrm{F}$.

Table 15. Scenario 2 Wetland Cell \#5 Maximum Temperature.

\begin{tabular}{|c|c|c|c|}
\hline \multicolumn{4}{|c|}{ WETLAND CELL 5 MAXIMUM TEMPERATURE (F) } \\
\hline PRECIP YEAR & 1996 & (Dry) & \\
\hline Wetland Area & \multicolumn{3}{|c|}{ Watershed to Wetland Area Ratio } \\
\hline Plant Capacity & 3 & 10 & 25 \\
\hline \multicolumn{4}{|l|}{100 Acre } \\
\hline $25 \mathrm{MW}$ & 84 & 83 & 82 \\
\hline $100 \mathrm{MW}$ & 96 & 93 & 90 \\
\hline $300 \mathrm{MW}$ & 100 & 100 & 99 \\
\hline $500 \mathrm{MW}$ & 101 & 103 & 100 \\
\hline \multicolumn{4}{|l|}{500 Acre } \\
\hline $25 \mathrm{MW}$ & 84 & 83 & 82 \\
\hline $100 \mathrm{MW}$ & 84 & 83 & 82 \\
\hline $300 \mathrm{MW}$ & 89 & 86 & 84 \\
\hline $500 \mathrm{MW}$ & 96 & 93 & 90 \\
\hline \multicolumn{4}{|l|}{1000 Acre } \\
\hline $25 \mathrm{MW}$ & 84 & 83 & 82 \\
\hline $100 \mathrm{MW}$ & 84 & 83 & 82 \\
\hline $300 \mathrm{MW}$ & 84 & 83 & 83 \\
\hline $500 \mathrm{MW}$ & 87 & 85 & 84 \\
\hline \multicolumn{4}{|l|}{5000 Acre } \\
\hline $25 \mathrm{MW}$ & 84 & 83 & 82 \\
\hline $100 \mathrm{MW}$ & 84 & 83 & 82 \\
\hline $300 \mathrm{MW}$ & 84 & 83 & 82 \\
\hline $500 \mathrm{MW}$ & 84 & 83 & 82 \\
\hline
\end{tabular}

Figures 23 and 24 show the temperature for wetland cells \#1 and \#5 over the course of a year for two cases. 


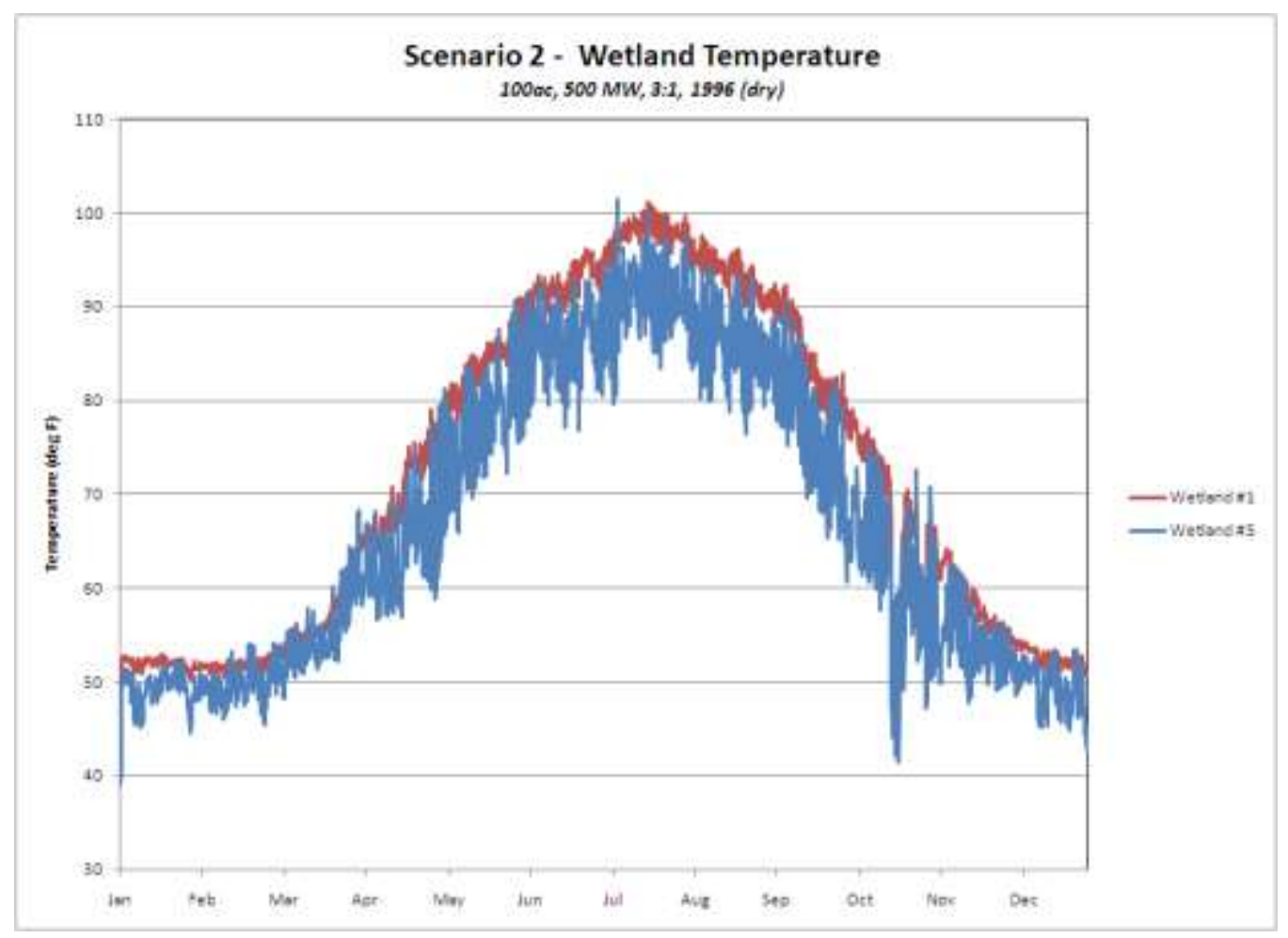

Figure 23. Wetland Temperature Change Over 1 Year for Case with Water Deficit.

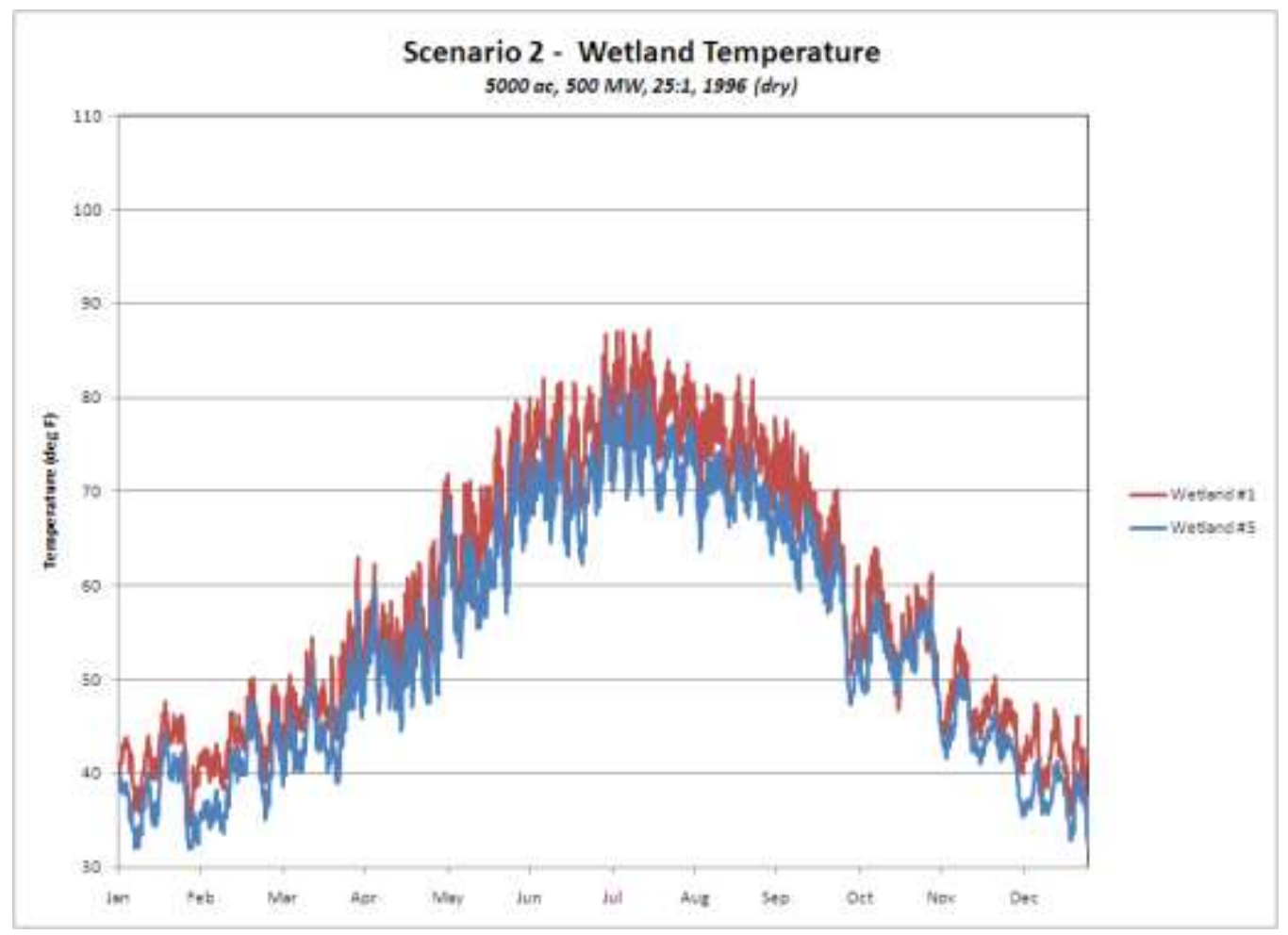

Figure 24. Wetland Temperature Change Over 1 Year for Case with Water Excess. 
These figures show the difference in maximum temperatures between the two cases presented and the difference in the temperatures in wetland cells \#1 and \#5 over the course of a year.

Another characteristic that showed little variation due to amount of precipitation, watershed to wetland area ratio, wetland area, or power plant capacity was the amount of cooling achieved (both maximum temperature difference and average temperature difference). In all cases that did not result in a volume deficit to the river, the average amount of cooling in the 5-cell wetland complex (temperature difference between power plant effluent and wetland cell \#5, maximum and average) was $19^{\circ} \mathrm{F}$.

Similar to a cooling tower or pond, the major water loss in a cooling wetland is due to evaporation. Results from Scenario 2 show that the amount of evaporation from the wetland is mainly a function of the wetland area and power plant capacity. If we look at the amount of evaporation from the wetland in excess of that from an ambient (natural) wetland (one that does not receive heated water from the power plant), the amount of excess evaporation that can be attributed to the heated inflow is approximately 270 $\mathrm{gal} / \mathrm{MWh}$. Again, this value is largely independent of amount of precipitation, watershed to wetland area ratio, wetland size, or power plant capacity.

\section{Scenario 3: Closed Loop System}

In Scenario 3, the model was set up to simulate a closed loop system where the wetland supplies the water required by the power plant condenser and cools the effluent before it is brought back into the plant for the next cooling cycle (Figure 25). Warmed water from the power plant is discharged to wetland cell \#1. The water then moves through the remaining wetland cells before it is taken back into the plant from wetland cell \#5 (water only flows in one direction, from 1 to 5). Flow between the wetland cells is set equal to the flow coming out of wetland cell \#5, except if the wetland depth is less than $0.5 \mathrm{ft}$, then there is no outflow from that wetland cell until the depth is greater than $0.5 \mathrm{ft}$. This prevents the wetland cells from drying out due to power plant demand (but subsequent evaporation, especially during drought years, could still result in wetland dry out). If the temperature in wetland cell \#5 is greater than $90^{\circ} \mathrm{F}$, the necessary power plant water is taken from the river and the water from wetland cell \#5 would be pumped elsewhere for additional cooling. The wetland cells are assumed to be hydraulically disconnected (they do not share a common water surface). As in Scenarios 1 and 2, each wetland cell receives water from direct precipitation and from runoff from the contributing watershed. Each wetland cell is modeled with an initial average depth of 3 $\mathrm{ft}$. 


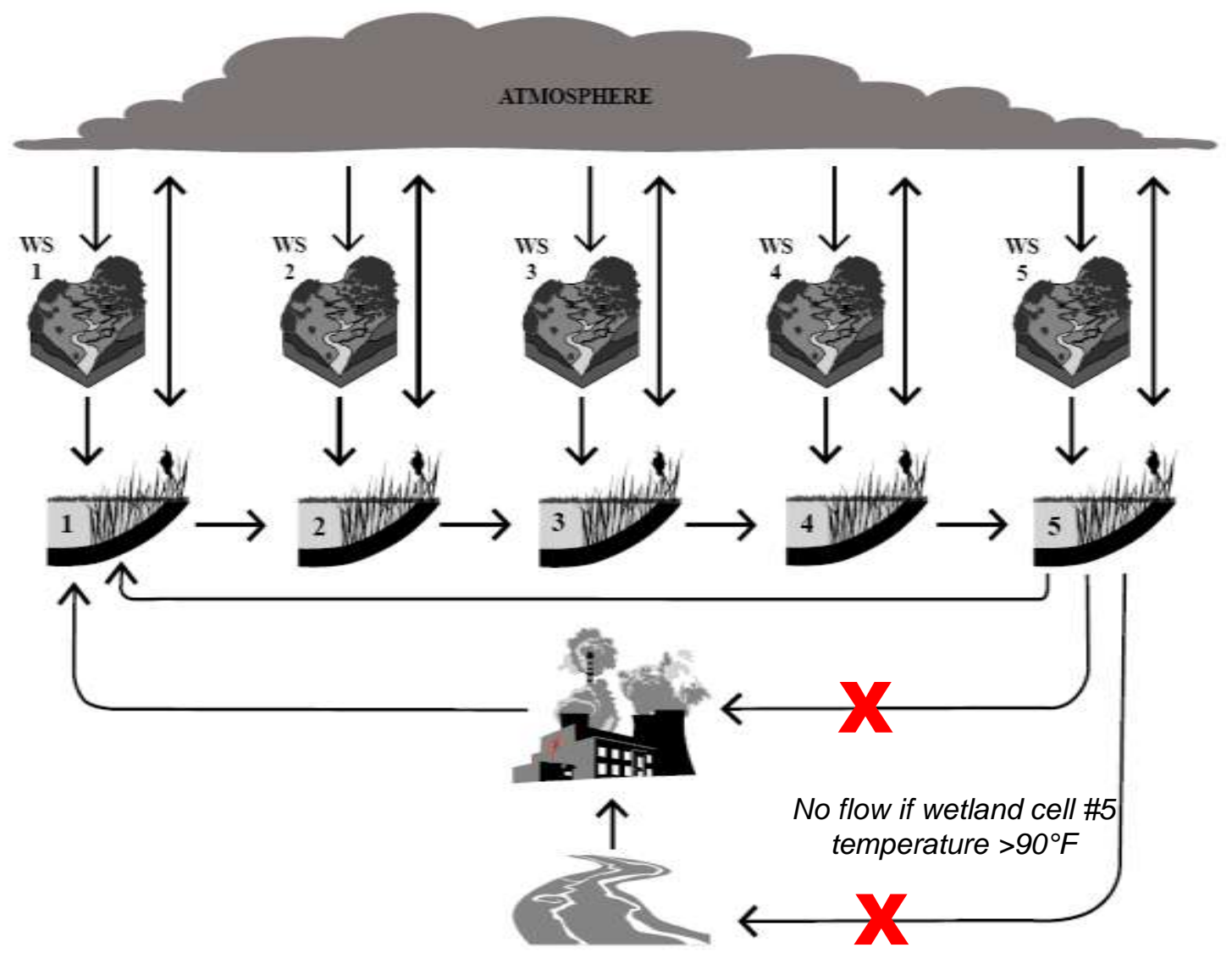

Figure 25. Scenario 3 diagram (red $X$ indicates that path is not active in current scenario).

For this scenario, model realizations are made to determine variable combinations that do not result in a deficit to the river and that do not exceed a specified temperature. This maximum temperature is typically stipulated in a power plant's discharge permit.

\section{Scenario 3: Results}

The model results for both the dry and average precipitation years show that in 13 of each of the 48 cases, the temperature in wetland cell $\# 5$ exceeded the maximum temperature (set at $90^{\circ} \mathrm{F}$ ) necessitating withdrawal from the river (Tables 16 and 17). Larger plant capacities and smaller watershed sizes contributed to greater river volume withdrawals. For wetland sizes equal to and greater than 1,000 acres, no river water was required, and maximum temperatures were not exceeded. 
Tables 16 and 17. Scenario 3 End of Year Surface Water Deficits.

\begin{tabular}{|c|c|c|c|}
\hline \multicolumn{5}{|c|}{ ANNUAL SURFACE WATER DEFICIT (Mgal) } \\
\hline PRECIP YEAR & 1996 & \multicolumn{1}{|c|}{ (Dry) } & \\
\hline Wetland Area & Watershed to Wetland Area Ratio \\
\hline Plant Capacity & 3 & 10 & 25 \\
\hline 100 Acre & & & \\
\hline $25 \mathrm{MW}$ & 0 & 0 & 0 \\
\hline $100 \mathrm{MW}$ & 104 & 94 & 51 \\
\hline $300 \mathrm{MW}$ & 4,949 & 4,856 & 4,887 \\
\hline $500 \mathrm{MW}$ & 18,616 & 18,806 & 18,736 \\
\hline $500 \mathrm{Acre}$ & & & \\
\hline $25 \mathrm{MW}$ & 0 & 0 & 0 \\
\hline $100 \mathrm{MW}$ & 0 & 0 & 0 \\
\hline $300 \mathrm{MW}$ & 32 & 0 & 0 \\
\hline $500 \mathrm{MW}$ & 518 & 469 & 257 \\
\hline $1000 \mathrm{Acre}$ & & & \\
\hline $25 \mathrm{MW}$ & 0 & 0 & 0 \\
\hline $100 \mathrm{MW}$ & 0 & 0 & 0 \\
\hline $300 \mathrm{MW}$ & 0 & 0 & 0 \\
\hline $500 \mathrm{MW}$ & 0 & 0 & 0 \\
\hline $5000 \mathrm{Acre}$ & & & 0 \\
\hline $25 \mathrm{MW}$ & 0 & 0 & 0 \\
\hline $100 \mathrm{MW}$ & 0 & 0 & 0 \\
\hline $300 \mathrm{MW}$ & 0 & 0 & 0 \\
\hline $500 \mathrm{MW}$ & 0 & 0 & 0 \\
\hline
\end{tabular}

\begin{tabular}{|c|c|c|c|}
\hline \multicolumn{4}{|c|}{ ANNUAL SURFACE WATER DEFICIT (Mgal) } \\
\hline PRECIP YEAR & 1984 & (Average) & \\
\hline Wetland Area & Watershed to Wetland Area Ratio \\
\hline Plant Capacity & 3 & 10 & 25 \\
\hline $100 \mathrm{Acre}$ & & & \\
\hline $25 \mathrm{MW}$ & 0 & 0 & 0 \\
\hline $100 \mathrm{MW}$ & 99 & 89 & 20 \\
\hline $300 \mathrm{MW}$ & 4,872 & 4,856 & 4,901 \\
\hline $500 \mathrm{MW}$ & 18,350 & 18,726 & 18,916 \\
\hline $500 \mathrm{Acre}$ & & & \\
\hline $25 \mathrm{MW}$ & 0 & 0 & 0 \\
\hline $100 \mathrm{MW}$ & 0 & 0 & 0 \\
\hline $300 \mathrm{MW}$ & 14 & 0 & 0 \\
\hline $500 \mathrm{MW}$ & 495 & 447 & 100 \\
\hline $1000 \mathrm{Acre}$ & & & \\
\hline $25 \mathrm{MW}$ & 0 & 0 & 0 \\
\hline $100 \mathrm{MW}$ & 0 & 0 & 0 \\
\hline $300 \mathrm{MW}$ & 0 & 0 & 0 \\
\hline $500 \mathrm{MW}$ & 0 & 0 & 0 \\
\hline $5000 \mathrm{Acre}$ & & & 0 \\
\hline $25 \mathrm{MW}$ & 0 & 0 & 0 \\
\hline $100 \mathrm{MW}$ & 0 & 0 & 0 \\
\hline $300 \mathrm{MW}$ & 0 & 0 & 0 \\
\hline $500 \mathrm{MW}$ & 0 & 0 & 0 \\
\hline & & & \\
\hline
\end{tabular}

Table 18 shows the maximum temperatures generated in wetland cell \#5 for a dry precipitation year. As was indicated above, the maximum temperature rose above $90^{\circ} \mathrm{F}$ for 13 of the 48 cases. The results were quite similar for the average precipitation year cases. For the cases where the temperature did not rise above $90^{\circ} \mathrm{F}$, the maximum temperatures, for the most part, were the same as the ambient wetland and were affected only slightly by the difference in watershed to wetland area ratio. 
Table 18. Scenario 3 Wetland Cell \#5 Maximum Temperatures.

\begin{tabular}{|c|c|c|c|}
\hline \multicolumn{4}{|c|}{ WETLAND CELL 5 MAXIMUM TEMPERATURE (F) } \\
\hline PRECIP YEAR & 1996 & (Dry) & \\
\hline Wetland Area & \multicolumn{3}{|c|}{ Watershed to Wetland Area Ratio } \\
\hline Plant Capacity & 3 & 10 & 25 \\
\hline \multicolumn{4}{|l|}{100 Acre } \\
\hline $25 \mathrm{MW}$ & 84 & 83 & 82 \\
\hline $100 \mathrm{MW}$ & 95 & 93 & 93 \\
\hline $300 \mathrm{MW}$ & 100 & 100 & 100 \\
\hline $500 \mathrm{MW}$ & 157 & 169 & 166 \\
\hline \multicolumn{4}{|l|}{500 Acre } \\
\hline $25 \mathrm{MW}$ & 84 & 83 & 82 \\
\hline $100 \mathrm{MW}$ & 84 & 83 & 82 \\
\hline $300 \mathrm{MW}$ & 90 & 88 & 85 \\
\hline $500 \mathrm{MW}$ & 95 & 93 & 93 \\
\hline \multicolumn{4}{|l|}{1000 Acre } \\
\hline $25 \mathrm{MW}$ & 84 & 83 & 82 \\
\hline $100 \mathrm{MW}$ & 84 & 83 & 82 \\
\hline $300 \mathrm{MW}$ & 84 & 83 & 82 \\
\hline $500 \mathrm{MW}$ & 87 & 85 & 84 \\
\hline \multicolumn{4}{|l|}{5000 Acre } \\
\hline $25 \mathrm{MW}$ & 84 & 83 & 82 \\
\hline $100 \mathrm{MW}$ & 84 & 83 & 82 \\
\hline $300 \mathrm{MW}$ & 84 & 83 & 82 \\
\hline $500 \mathrm{MW}$ & 84 & 83 & 82 \\
\hline
\end{tabular}

Similar to Scenario 2, the difference between the average plant effluent and wetland cell \#5 temperatures was $19^{\circ} \mathrm{F}$ for the majority of the Scenario 3 cases. The only deviations from this value were in the cases where the wetland cell $\# 5$ maximum temperature exceeded $90^{\circ} \mathrm{F}$ and the water from wetland cell \#5 was recirculated through the wetland for additional cooling. In those cases, the difference between the average plant effluent and wetland cell $\# 5$ temperatures was slightly less than $19^{\circ} \mathrm{F}$.

For Scenario 3, the amount of excess evaporation from the wetland due to the heated inflow was approximately $268 \mathrm{gal} / \mathrm{MWh}$, very similar to the Scenario 2 results (270 $\mathrm{gal} / \mathrm{MWh}$ ). Again, this value is largely independent of amount of precipitation, watershed to wetland ratio, wetland size, or plant capacity.

The amount of evaporation occurring in each of the wetland cells is directly proportional to the amount of cooling achieved. The Scenario 3 results show that on average, almost $30 \%$ of the cooling occurs in wetland cell \#1 and slightly more than $20 \%$ occurs in wetland cell \#2, except for those cases with large wetland areas and low power plant capacities. In those cases, the amount of cooling in each wetland is approximately equal. 


\section{Discussion}

The three scenarios investigated in this study were used to demonstrate the practicality of using wetlands for providing an additional clean water source for power plants and as an alternative for cooling a plant's heated effluent. Scenario 1 was designed to show the ability of a wetland to harvest water from direct precipitation and watershed runoff as a source for makeup water for a typical cooling tower. Beyond cooling towers, there are numerous other power plant water requirements that could be supplied by a wetland. Scenarios 2 and 3 showed how a wetland could be used to cool heated effluent in both once-through and closed-loop systems.

Concerning overall water balance and water loss from the system, each Scenario demonstrated the characteristics necessary to result in a sustainable system - one where water lost to processes such as evaporation is at least balanced by water harvested from the wetland and contributing watershed. In each Scenario, the results showed that wetlands of 500 acres or less could only provide the total required water volume for cases where there were very large watersheds or low plant capacities. Even though smaller wetlands may not be able to supply the total amount of makeup or cooling water required, they do have the potential to provide a portion of the water needs, thus reducing the impacts on local surface water or groundwater sources. Also, the smaller wetlands could be used in conjunction with another alternative water source (e.g., wastewater treatment plant effluent) to satisfy a power plant's requirements.

A factor affecting the water harvesting potential of a wetland, beyond the size of the contributing watershed, is the type of land use/cover in the watershed. For the demonstration modeling purposes, it was assumed that the watershed was largely agricultural (the model can be user-modified to reflect a more urbanized watershed, forested areas, or other land cover scenarios). Power plants located in more developed areas may have the potential of harvesting more water due to the increased runoff resulting from development. These same areas may also be experiencing flooding issues if proper stormwater management has not been achieved in the watershed. In this case, harvesting excess water from watersheds with these problems would potentially help relieve local and downstream flooding. There is also an opportunity, with small and large wetlands to harvest and infiltrate water during wetter periods, thus returning water to the groundwater aquifer and fully or partially offsetting the volume that may need to be pumped from the groundwater during dry periods. (Note: AES has previously sold stormwater management credits to help relieve stormwater flooding impacts and this has been a very valuable revenue source that has more than paid for the costs of constructing some smaller wetland projects. This additional potential revenue stream is not addressed in this modeling because aligning local needs with this opportunity are very site-specific.)

While the correct combination of system characteristics can provide a sustainable system, there is still water lost due to evaporation (the primary cooling function). The model results showed that generally, the amount of water lost in the wetland to evaporation (over that which is lost in an ambient wetland) is about $270 \mathrm{gal} / \mathrm{MWh}$. This 
volume of water loss is approximately equal to what is reported for heated water being released directly into a river ( $\sim 300 \mathrm{gal} / \mathrm{MWh})$, less than that generally lost in a cooling tower ( 480 gal/MWh), and equal to the lower value reported for cooling ponds (270$500 \mathrm{gal} / \mathrm{MWh})$.

The results from Scenarios 2 and 3 demonstrate that wetlands can provide substantial cooling capacity in both once-through and closed-loop systems. When the system characteristics are such that there is adequate water volume available (i.e., wetlands are not remaining at their minimum levels), the maximum and average temperatures in the final wetland cell (\#5) are approximately equal to those in an ambient wetland. The model shows those temperatures are generally insensitive to watershed size, wetland size, and plant capacity.

The ecological integrity of the wetlands used in the three Scenarios is affected by two primary factors: water level (depth) changes and water temperature changes. In the most dramatic cases, wetlands dried out, which obviously has significant effects on wetland plant and animal communities as well as many other wetland functions (e.g., groundwater recharge). Cases where water levels were lowered (losses>gains) may compromise some wetland plant and animal communities, depending on species lifecycle requirements and wetland basin geometry and heterogeneity. Reduced water levels would also be expected to result in increased warming of water from solar radiation, so although heated effluent may not be discharged to the wetlands (e.g., Scenario 1), the project wetlands may still indirectly experience increased temperatures as a result of their use for makeup water. Wetlands that experienced increased water levels (losses<gains) could be fitted with water control structures that ensured water levels were managed for healthy plant and animal communities and full wetland functions.

With regard to thermal discharges into the project wetlands, Scenario 2 occasionally resulted in significantly elevated temperatures in the wetland cells $\left(>100^{\circ} \mathrm{F}\right.$ in wetland cells \#1 through \#5); for comparison, ambient (natural) wetlands during these same hottest days were $\sim 83-84^{\circ} \mathrm{F}$. These most extreme cases assumed "worst-case" conditions, including small wetlands, small to moderate watersheds, and high capacity power plants operating during a dry year. The wetlands in these "worst condition" cases would be noticeably compromised in terms of their ecological integrity, but the limited period of significant heating ( $<3$ months) would be expected to enable survivorship of a modest diversity of aquatic flora and fauna. Scenario 2 cases considering larger wetlands and watersheds (but still high generating capacity and dry climate conditions) exhibited much lower thermal loading to project wetlands $\left(\sim 87^{\circ} \mathrm{F}\right.$ in wetland cell \#1 and $82^{\circ} \mathrm{F}$ in wetland cell \#5), very close to ambient wetland temperatures. With regard to thermal discharges from the cooling wetlands into receiving waters (e.g., rivers), in the majority of cases Scenario 2 resulted in a maximum discharge temperature of $82^{\circ}$ to $84^{\circ} \mathrm{F}$. The primary exceptions (discharges $>84^{\circ} \mathrm{F}$ ) were mostly found in cases using the smallest wetland (100 acres) and/or the larger (300-500 MW) power plant capacities (Table 15). Discharges of $\leq 84^{\circ} \mathrm{F}$ water into receiving waters would not be expected to have significant adverse effects on most warm water aquatic organisms. 
With regard to thermal discharges from the cooling wetlands into receiving waters, Scenario 3 cases resulted in wetland cell \#5 temperatures very similar to those found in Scenario 2, with the distinct exception of the smaller wetlands (100 acres) matched with the $500 \mathrm{MW}$ capacity power plant. Wetland cell \#5 discharge temperatures were modeled to be $157^{\circ} \mathrm{F}$ (for the $3: 1$ watershed to wetland area ratio case), $169^{\circ} \mathrm{F}$ (for the 10:1 ratio) and 166 (for the 25:1 ratio) (Table 18). These extremely hot effluents would essentially eradicate all life in the vicinity of the discharge, with the possible exception of thermophylic bacteria and possibly some blue-green algae. By modeling these cases, the final wetland design can be formulated to avoid this type of condition.

\section{Phase II Model Testing and Calibration with Wetland Demonstration Project Data}

The Phase II demonstration wetland system differed from the Phase I theoretical wetland system for which the STELLA model was developed. The differences included:

- Wetland inflow water from a cooling pond instead of directly from the power plant

- Linear, narrow wetland cells instead of cells with widths approximately the same as the lengths

- 3 wetland cells instead of 5

- Permeable sandy soils underlying the wetland cells instead of the relatively impermeable clayey soils assumed in the theoretical model

The Phase I, Scenario 3 model was used for Phase II testing and calibration since water is pumped from a cooling pond immediately downstream from the plants discharge location and pumped back into the cooling pond after being routed through the wetland similar to the stream intake and outlet used in Phase I Scenario 3. The power plant discharge water/heat was set to 0 in Phase II.

For testing and calibration purposes, modeled wetland inflow and outflow water temperatures, individual wetland cell water temperatures and individual wetland cell water elevations were compared with measured data. Water elevation measurements were taken between April 19, 2012 and June 19, 2012 and water temperature measurements were taken between April 19, 2012 and September 30, 2012.

Three wetland cells are used in this model. Cell 1 is the east end of the north channel (approximate length $=3140$ '; Cell 2 is the west end of the north channel (approximate length $=1300^{\prime} ; \quad$ Cell 4 is the south channel (approximate length $=4420^{\prime}$ ). Wetland cell bottom widths were averaged for the cells from surveyed cross sections. The wetland initial depths were the difference between the average cell wetland bottom elevation and the initial measured water elevation. Average wetland bottom elevations are: cell 1 - 154.0, cell 2 - 154.3, cell 4 - 157.4

Water inflow/outflow rates were calculated using measured pump operation periods and pump rating curves. 
The atmospheric data set is from weather station at the site with data collected in 15 minute increments and averaged, summed or factored as necessary to obtain data for the 4 hour model time step.

The Phase I model was modified to included groundwater infiltration/exfiltration gain/loss. Field observations of the wetland system found that the wetland system was never empty, even during the dry summer season. This indicated that groundwater infiltration into the wetland system occurs. Therefore, the final model included a minor infiltration rate of .04 feet per four-hour model time step ( 0.12 inches per hour) which was applied to the wetland cell bottom area.

The elevated nature of the wetland cells also precluded any significant surface water runoff from precipitation events from discharging into the wetlands, hence the low 0.1 value used for the watershed to wetland area ration used in the calibration model.

For the period of measurement, modeled wetland temperatures for the inlet cell and the outlet cell showed close correlation with the measured wetland cell temperatures (Figures 26 and 27). Similarly, the modeled and measured wetland cell water elevations also showed close correlation although the modeled water elevations were consistently above the measured elevations (Figures 28 and 29). This variation is possibly due to a difference between actual and measured wetland cell volumes and/or seasonal groundwater movement fluctuations. With the groundwater infiltration rate set to 0 in the model, good agreement was found between the measured and modeled data for the period that measured data was collected; however, during the dry summer season, the model showed the wetland drying out with no infiltration and field observations found that the wetland system was never dry. 


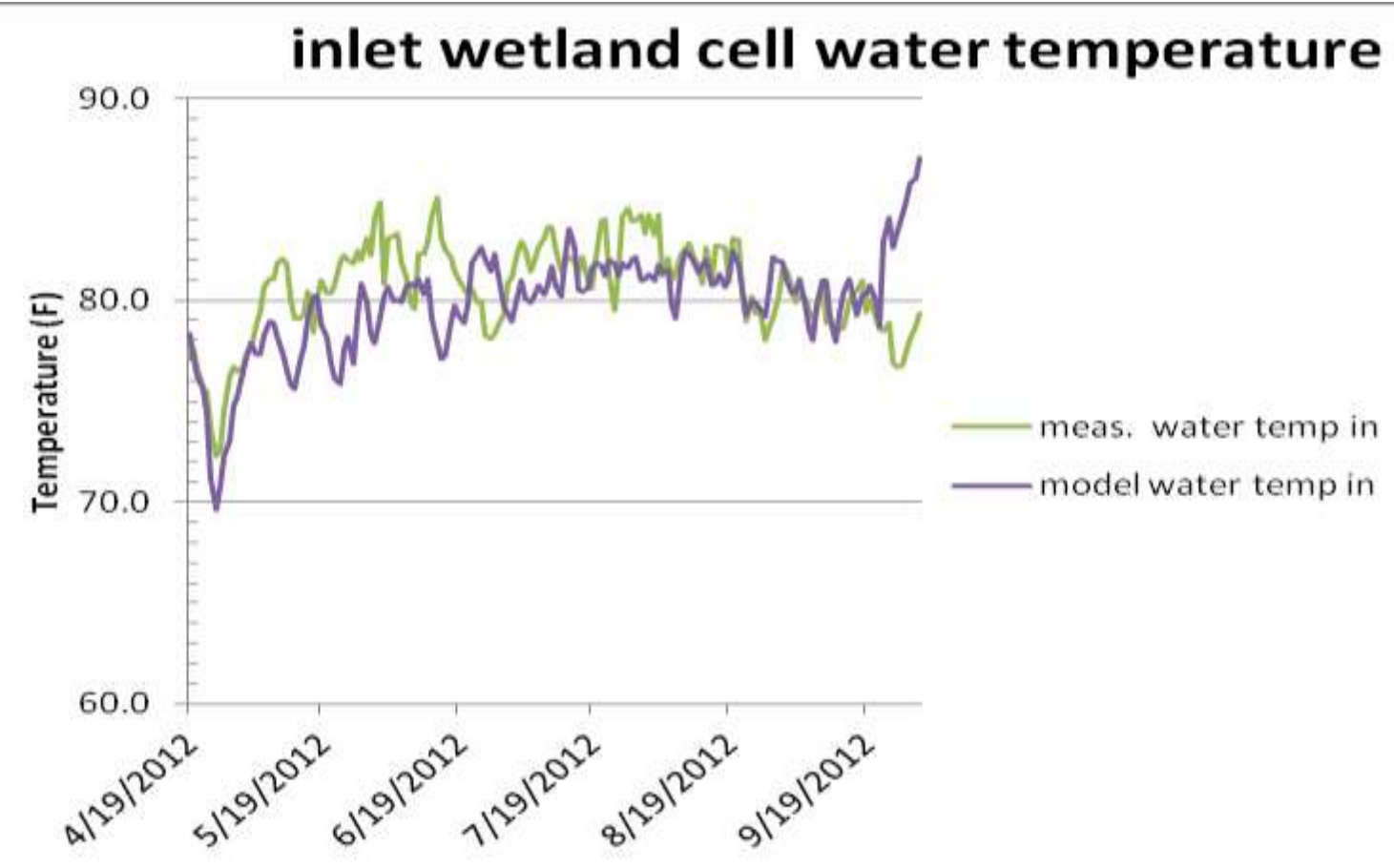

Figure 26. Modeled vs. Measured Wetland Cell Water Temp Comparison (Inlet).

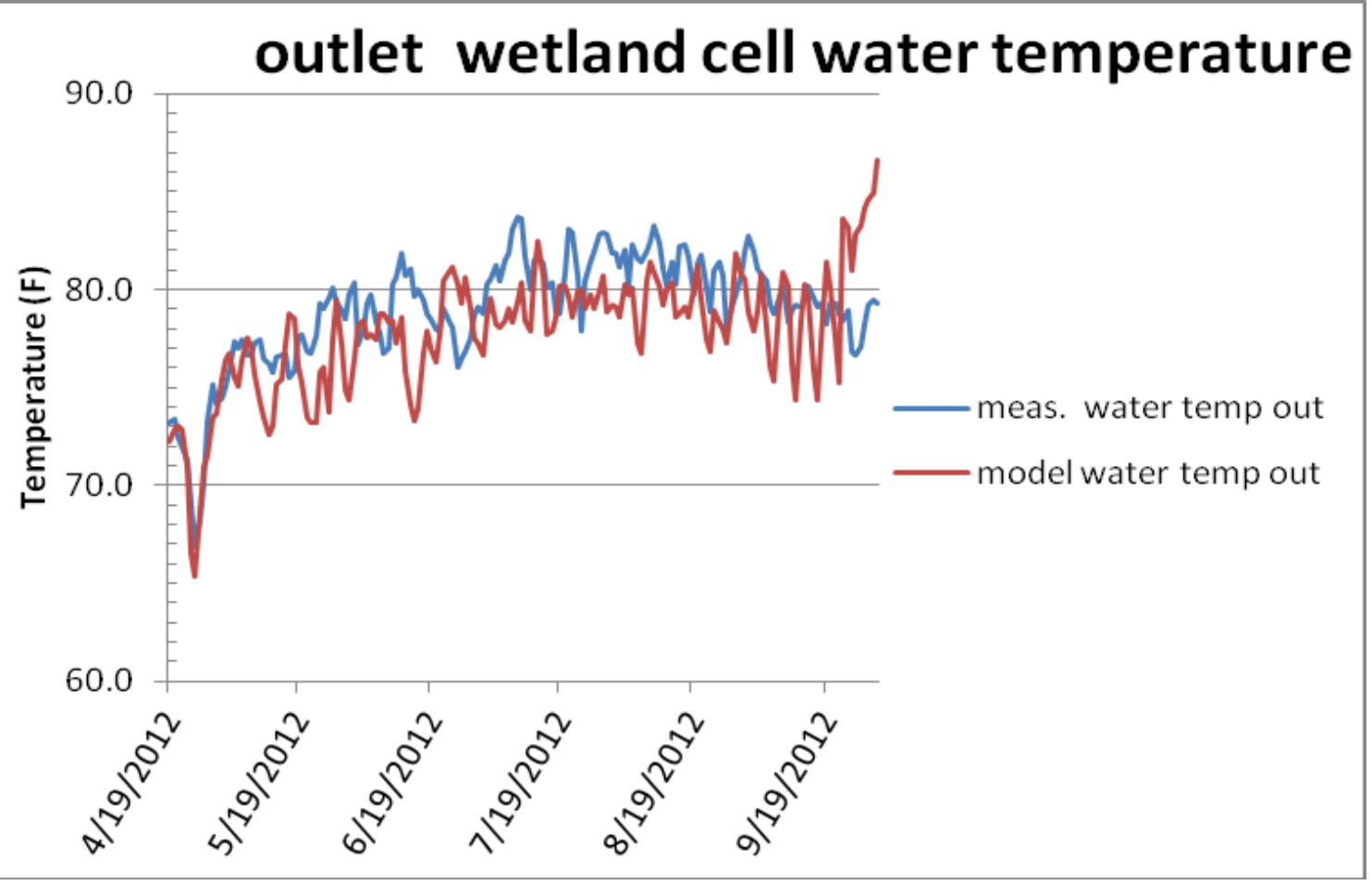

Figure 27. Modeled vs. Measured Wetland Cell Water Temp Comparison (Outlet). 


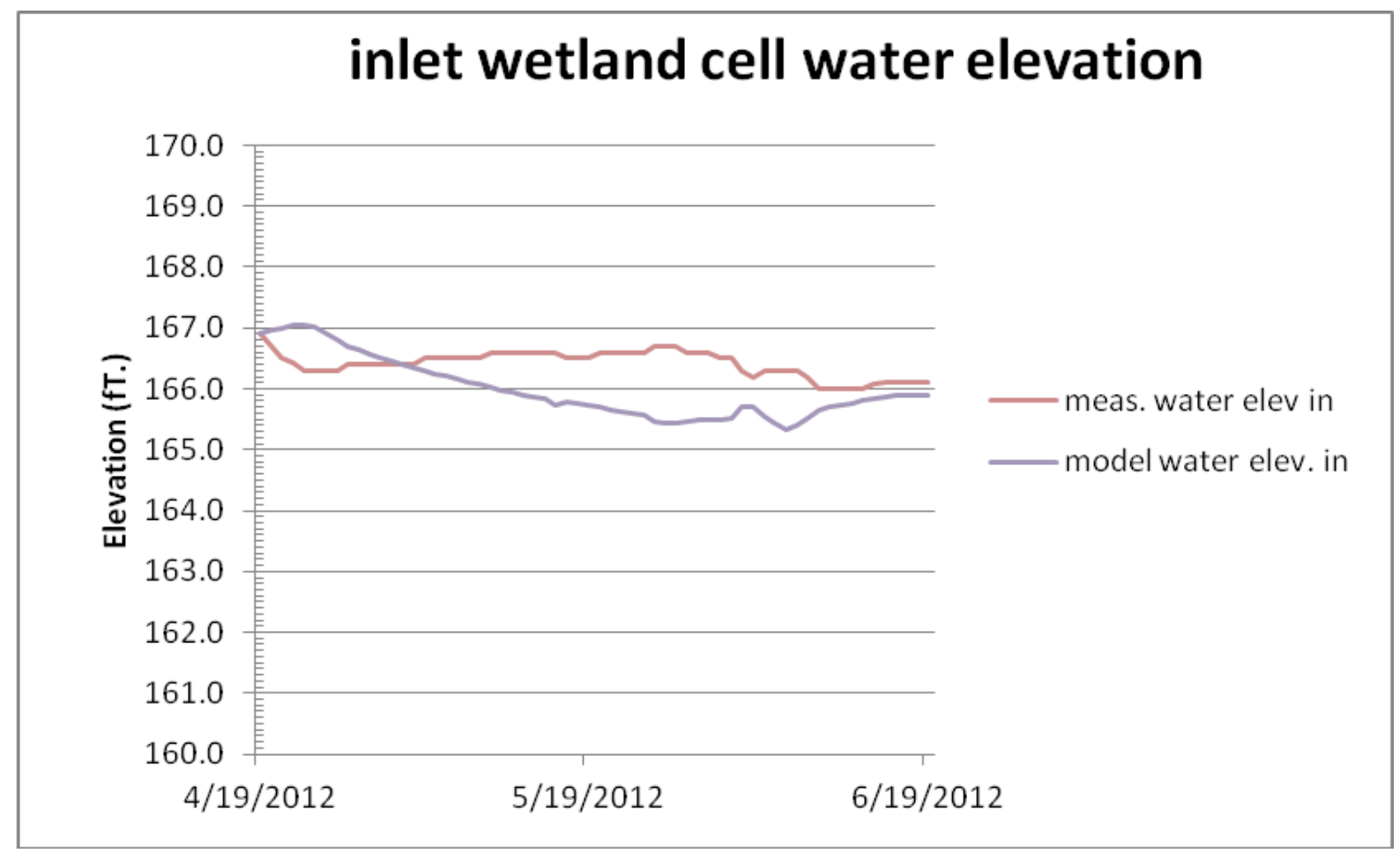

Figure 28. Modeled vs. Measured Wetland Cell Water Elev. Comparison (Inlet)

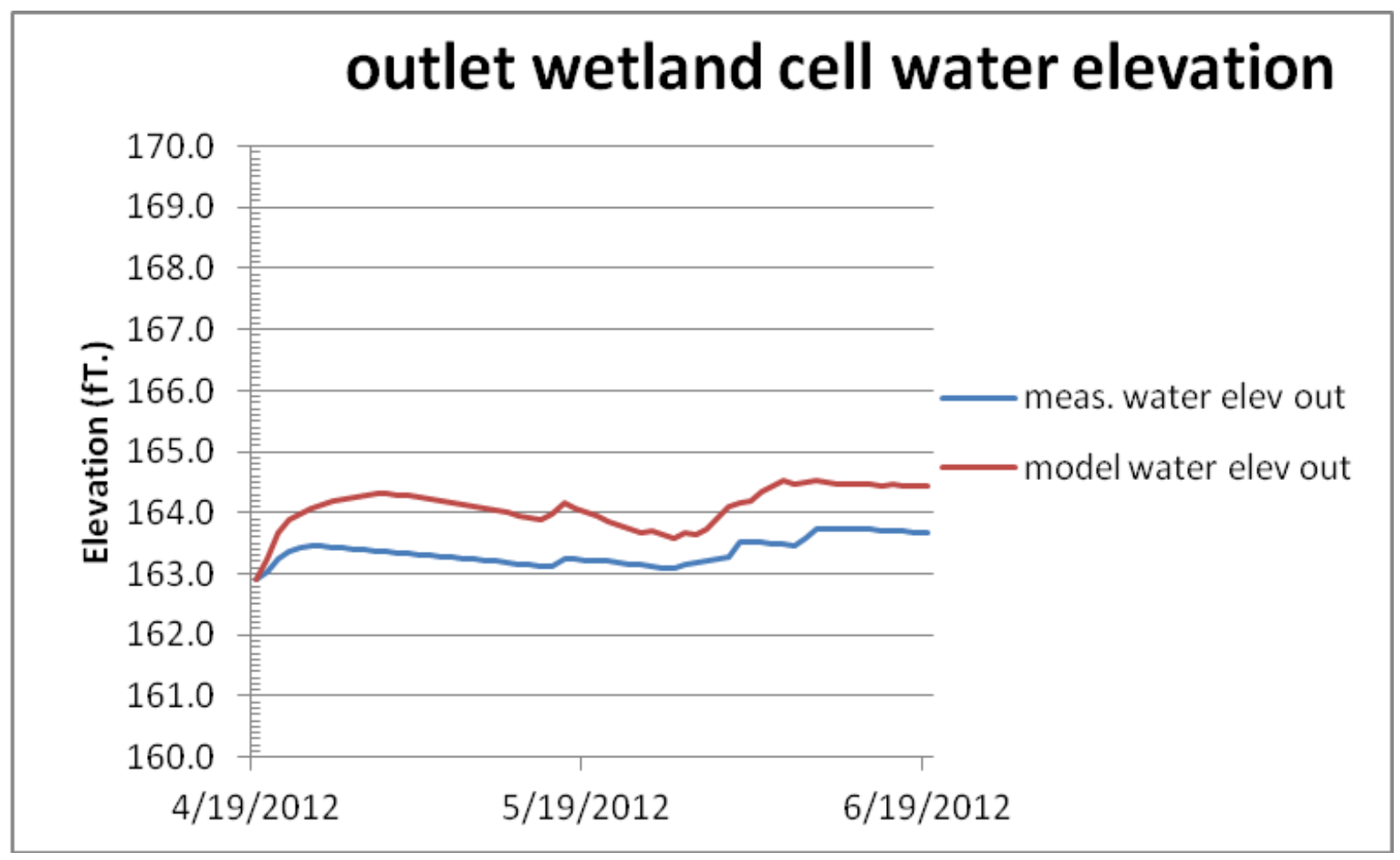

Figure 29. Modeled vs. Measured Wetland Cell Water Elev. Comparison (Outlet) 


\section{CHAPTER 6 - WETLAND WATER COOLING DEMONSTRATION PROJECT}

\section{Site Selection}

As described in the Case Study section above, Hines Energy Complex in Bartow, Florida has already completed a number of innovative water harvesting projects to begin addressing the water needs for their combined cycle power plant. Progress Energy Florida, and now Duke Energy Florida, are committed to exploring innovative methods to assist with their cooling needs that are both environmentally friendly and economically viable.

The total Hines Energy Complex site occupies 8,200 acres, with the generating plant and cooling pond using approximately 1,500 acres. The balance of the property is land formerly mined for phosphate and is currently characterized by a gentle rolling topography with intervening depressions, many having converted to wetlands and lakes that occupy former mine pits. Additional areas have been used for reclamation and restoration of natural habitats for wildlife, as required by various state permits.

The Hines Energy Complex in Bartow, Florida, was a suitable candidate for a wetland demonstration project based on a number of criteria. First, the Hines Energy Complex is very interested in developing a large-scale demonstration project and has forward thinking operations and environmental staff. Their operation is already a closed loop water supply and beneficial re-use system. Yet, they are interested in any additional activities they can complete to benefit the plant's operation. Second, the Hines Energy Complex has already developed a 1,200-acre cooling pond to recycle water from the plant. Much of the remainder of the site's natural habitats are used to harvest and store rainwater, runoff, and wastewater effluent from the City of Bartow. They rely extensively on alternative supplies and water harvesting from wetland systems. The harvested water is pumped to the cooling pond along with blowdown that is discharged from the plant boilers.

Progress Energy had a long history of working cooperatively with a host of researchers focused on water quality and quantity related issues specific to the region of central Florida. The energy-water nexus is a major issue in drought prone regions of the southeastern U.S. and Progress Energy began proactively addressing their issues more than a decade ago. For all of these reasons, the Hines Energy Complex was an obvious fit during our search for a pilot site. They were very interested to work collaboratively on the pilot demonstration project and continue their commitment to innovative methods of water reuse and applied research. Additionally, their historical monitoring data from the site provided an excellent baseline for the initial pilot project design. 


\section{Other Sites Considered for Pilot Study}

The other plant that was considered for the study was the Schahfer facility a 1,943 MW coal-fired plant located in northwestern Indiana that currently uses deep groundwater as its primary source of water for cooling. From discussions and review of site plans, NIPSCO was also interested in exploring alternate sources of cooling water and alternatives to discharging water directly to the Kankakee River. The Schahfer facility is also surrounded by thousands of acres of land suitable for wetland restoration, making the site a good alternative candidate for the demonstration project.

\section{Pilot Study Design and Methodology}

Upon deciding to focus on the Hines Energy Complex for the water cooling demonstration study, the consulting team worked with the power plant to evaluate project sites suitable for the pilot study. The "racetrack" wetland was selected for the initial pilot study.

\section{Study Design and Parameter Selection}

The team designed a monitoring instrumentation plan for the linear racetrack wetland ditch system to characterize temperature profiles throughout the three cells (as reflected in the STELLA model). By comparing the inlet temperatures and the outlet temperatures, the monitoring documented the cooling benefits of the wetland and provided monitoring data to calibrate heat and mass transfer calculations in the model. The monitoring equipment continuously recorded: soil and water temperature, conductivity, and water elevation in the racetrack wetland for 18 months. Flow (volume) data was collected and incorporated in the data analysis process.

Along the course of the 2.2 mile racetrack channel, several locations were identified as divisions between zones of most consistent cross-sectional area (the unit cells). The monitoring locations included: AMS-I, AMS-O, AMS-2, AMS-3, AMS-4, AMS-5, AMS-6, EMS-I, EMS-O, EMS-2, EMS-3, EMS-4, EMS-5, and EMS-6 (Figure 30 below). 


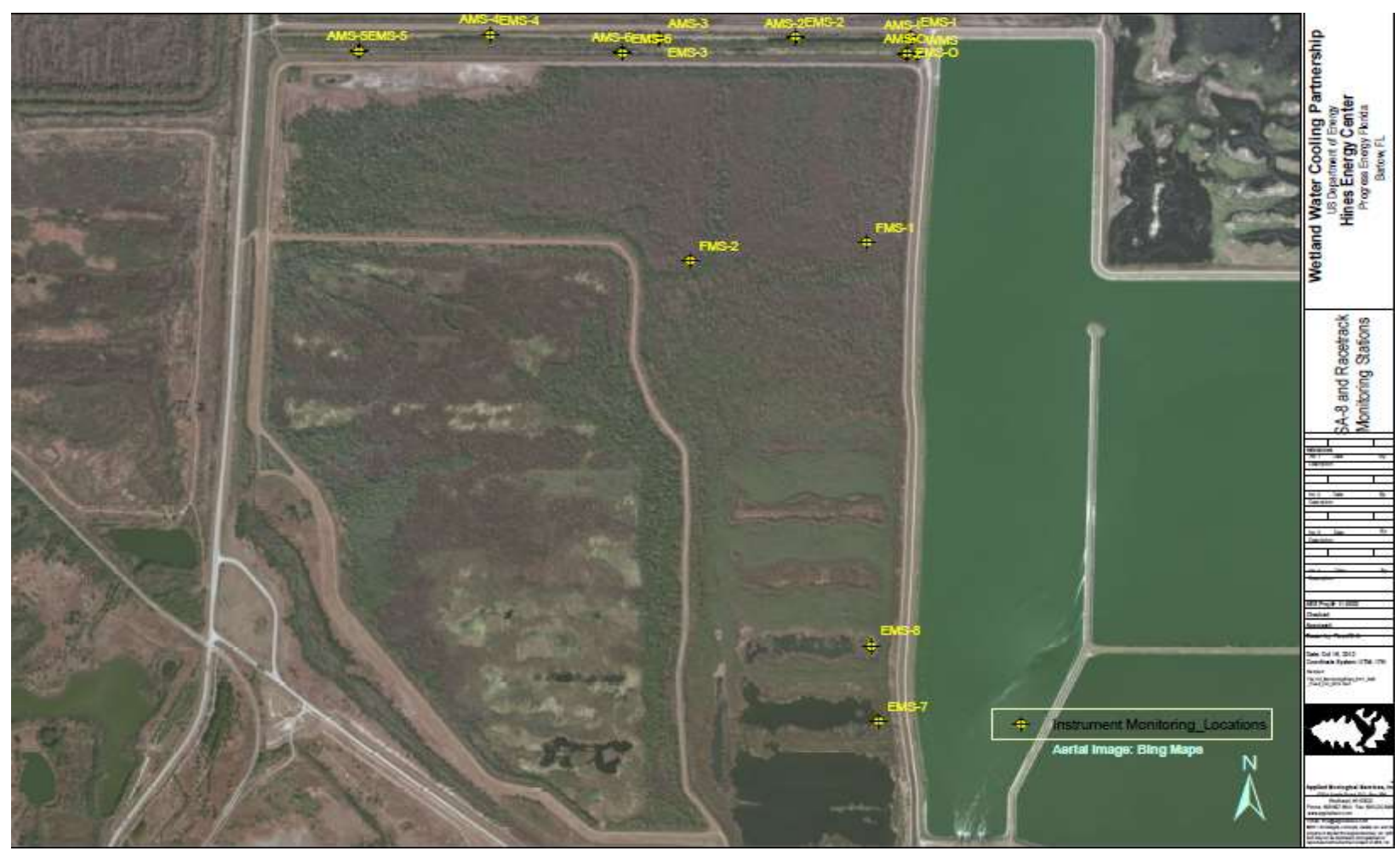

Figure 30. Monitoring Station Locations - Racetrack and SA-8 wetlands Hines Energy Complex, Bartow, Florida

At these locations, five monitoring stations were installed thta recorded both soil and water temperature at different elevations characterizing the entire water body as it passed through the loop system. There were three primary types of monitoring stations installed, including:

- Aquatic Monitoring Stations (AMS) (water and soil)

- measured soil temperature at 3 " and 12 " below substrate

- measured water temperature at 3" above substrate and 3" below water surface

- Aquatic Monitoring Stations (AMS) (water only)

o measured water temperature at 3" above substrate and 3" below water surface

- Emergent Monitoring Stations (EMS) (water only)

o measured water temperature at 3 " below water surface

There were several additional monitoring stations installed within the SA-8 wetland - EMS-7, EMS-8, FMS-1, and FMS-2 - to serve as a control during the racetrack phase:

- Emergent and Forested Wetland Monitoring Stations (EMS/FMS) (water and soil)

- measured soil temperature at 3" and 12" below substrate

- measured water temperature at 3 " below water surface 
Monitoring equipment required manual download, with the exception of the OTT sensors, and included:

- HOBO Water Temp Pro v2, p/n U22-001 (near-surface water temperature measurements in aquatic and emergent locations), and Optical Data Shuttle

- HOBO 12-Bit Temperature Probe, p/n S-TMB-M002, S-TMB-M006 (in-soil and near-substrate temperature measurements)

- HOBO Micro Station Logger, p/n H21-002 (data logger, above-water interface for 12-bit temperature probes) and U-Shuttle, p/n U-DT-1

- OTT CTD Groundwater Data Logger (data logger, near-substrate temperature, water level, salinity measurements)

In addition to the temperature monitoring stations listed above, the study included monitoring stations installed at the inlet and outlet of the racetrack wetland with OTT CTDs that recorded water level, conductivity, and temperature.

Parameters were selected for a $\mathrm{HOBO}$ weather station based on their significance in heat loss calculations and the STELLA model inputs necessary. The parameters that were chosen were: air temperature, solar radiation, air dew point, atmospheric pressure, relative humidity, wind speed, and precipitation.

\section{$\underline{\text { Topographic Survey }}$}

In addition to equipment installion, the monitoring team completed a topographic survey of the racetrack wetland using a Trimble R8 survey-grade GPS. The survey intended to give the project team a better understanding of the depth and shape of the racetrack wetland for calibrating the STELLA model. The objective was to collect cross-sections at regular intervals throughout the inflow and outflow channels, from bank to bank. However, the monitoring team could not obtain some cross-sections and points because of vegetation interference, particularly in the outflow channel.

At a glance, the survey revealed that the depth and shape of the inflow and outflow channels are fairly consistent along the length of the racetrack wetland, with the exception of the areas near the inlet and outlet pumps. These areas are currently wider and in some cases much deeper than the rest of the channel. The results of the survey were analyzed in more detail and graphically depicted by one of the consulting team's engineers. This analysis allowed the team to determine correlations between the depth and shape of the channel and significant changes in temperature and other parameters being measured along the racetrack wetland.

\section{Natural Resources Inventory}

AES ecologists conducted two natural resource inventories of the racetrack and SA-8 wetlands in April 2011 and April 2012. The purpose of these inventories was to document ecological conditions prior to pumping water from the cooling pond through the wetland system and after water from cooling pond had been pumped through the wetland. 
During the natural resource inventories, AES ecologists collected the following data:

1. Wetland soils to test total phosphorus and carbon levels

2. Herbaceous and woody vegetation cover and diversity

3. Plant tissues (herbaceous and woody) for phosphorus analysis

4. Macroinvertebrates for diversity and abundance measurements

5. Reptile, amphibian, and avian diversity and abundance observations

Six sample points were designated along the racetrack wetland; three along the north channel and three along the south channel. At each sample point, vegetation and soils data was collected in aquatic and riparian wetland plots. Data collection methods for each of the above-listed parameters are described below.

\section{Soil Sampling}

At each of the six sampling locations, soil samples were collected from paired emergent and riparian wetland points. Sampling at the riparian wetland points involved digging a soil pit to a depth of 18-24' and collecting samples of 'A', 'B', and 'C' horizons in 18-0z Whirl-pak bags based on observed changes in soil color and texture. Two replicate probe samples were taken at random points around each pit so that three sets of bagged $A, B$, and $C$ horizon samples could be combined in the lab to form one composite sample per horizon for testing.

Emergent soil samples were acquired by pressing a 24" sludge and sediment sampling probe into soft aquatic substrate at a point in the channel corresponding to the riparian wetland sampling point on the bank. After the plastic liner inside the probe had captured an adequate soil sample, the liner was extracted from the probe, capped, and labeled to be sent to the lab. Horizon breaks were determined in the lab based on obvious color or textural changes.

All soil samples were tested for total phosphorus, total nitrogen, percent total carbon, percent inorganic carbon, percent organic carbon, and $\mathrm{pH}$.

\section{Herbaceous and Woody Vegetation Cover}

At each of the six racetrack wetland sampling points the team recorded herbaceous plant cover using the Braun-Blanquet cover-abundance scale for $1-\mathrm{m}^{2}$ quadrats in paired aquatic and emergent/riparian wetland points. Additionally, an overall plant species list was collected in a $5 \mathrm{~m}^{2}$ area around each sampling location. The total species list included shrubs and trees in addition to herbaceous vegetation.

\section{Reptile, Amphibian and Avian Diversity and Abundance Observations}

The team conducted twelve 10-minute point count bird surveys, corresponding with the six sampling points along the north and south channels of the racetrack wetland. Each point count was repeated during a different time on a second morning to maximize the 
sightings and diversity observed. The surveys occurred at dawn to maximize the number of sightings. For each survey point the team recorded all bird species seen or heard and estimated their relative abundance.

The team conducted formal amphibian calling surveys at four points along the racetrack wetlands on two nights. Species heard calling were documented, as well as calling intensity and an estimate of the number of individuals involved. Additionally, the team recorded incidental observations of insects, mammals, amphibians, and reptiles throughout the field work effort.

\section{Monitoring Data Acquisition}

Monitoring data collection of temperature, water level and conductivity in the racetrack wetland and SA-8 began in June 2011. Data acquisition methods included:

- The HOBO Water Temp Pro v2s and HOBO Micro Station Loggers record water temperature and soil temperature data every fifteen minutes. Optical shuttles and U-shuttles were used to download the Temp Pro v2s and Micro Stations, during bi-monthly site visits.

- The OTT CTD downloaded using Hydras 3 remote communication and data was downloaded remotely. The downloaded data was reviewed and compiled into Excel spreadsheets for analysis using SAS statistical analysis software and also used to calibrate the STELLA model.

- During the bimonthly site visits, the monitoring team used a portable $\mathrm{pH} /$ conductivity/temperature probe to take in-situ surface water readings at the monitoring stations in the racetrack wetland.

- Weather station data, available online at and was downloaded on a bimonthly basis at the time the temperature data was analyzed.

\section{Pilot Study Results}

\section{General Findings}

An approximate 8-degree Fahrenheit drop in temperature was achieved during the hottest months of the year when water shortages and heat stress affect power plant production efficiency (July-August).

The racetrack wetland results suggest with optimization, more significant, practical and cost effective cooling and cleaning benefits will be observed from a single pass of heated power plant effluent water through a restored wetland. Additional cooling is expected to be achieved by optimizing (e.g., night discharge pumping can achieve an additional 5 Deg. F cooling benefit) and (water pumped from greater depths can deliver water cooled an additional 5 Deg. F). 


\section{Statistical Analysis}

Statistical analysis of water temperature, flow volume, and meteorological data using SAS statistical analysis software. Continuous data was analyzed from seven monitoring stations using applied descriptive statistics, and multivariate variance and regression approaches to determine effectiveness of the wetland for reducing water temperature.

The results showed that the surface water temperatures at both aquatic and emergent monitoring stations (AMS and EMS) at the inlet are significantly higher than the temperatures at the outlet (Appendix Chapter 6, Fig. 1). On average, the aquatic temperature at the inlet is $5.5^{\circ} \mathrm{F}$ higher than at the outlet (Appendix Chapter 6, Fig. 4c), and the emergent temperature differed by $3.8^{\circ} \mathrm{F}$ between station 4 and 6 (Appendix Chapter 6, Fig. 5). In addition, seasonal variations in the temperatures are noticeable, with stronger temperature differences in spring than in summer. Water temperature 3 inches above the sediments, and 3 inches and 12 inches in the sediments at the inlet were $5.6^{\circ} \mathrm{F}, 9.0^{\circ} \mathrm{F}$, and $7.6^{\circ} \mathrm{F}$ higher than those in the outlet.

Regression analysis indicated that differences in temperature at the aquatic monitoring stations at the inlet and outlet are strongly correlated to net water pumped into the wetland and weather conditions characterized by gust wind speed, solar radiation, air temperature, relative humidity, and air pressure. The six independent variables explained $70 \%$ of this variance. Among the six variables, net water pumped into the wetland, solar radiation, and air pressures are positively correlated to differences in temperature at the aquatic monitoring stations at the inlet and outlet, and the remaining variables are negatively related to it. Partial correlation coefficients indicated that the most to the least important variables are air pressure, net water pumped into the wetland, air temperature, solar radiation, relative humidity, and gust wind speed. Temperature changes over the monitoring period indicated that average temperature decreased gradually from inlet to outlet (Appendix Chapter 6, Fig. 10).

\section{Natural Resources Inventory}

The Natural Resources Inventory results show exceptional diversity at the Hines Energy Complex, especially in the wetlands. Many plant and animal species depend on wetlands for completing their life cycles, including rare species. At the Hines Energy Complex there were 83 bird species observed in April 2011 and 113 bird species observed in April 2012. The increase in wetland area could account for the greater abundance and richness of bird species at the Hines Energy Complex. Repeat sampling is necessary to verify this assumption that increased wetlands increase bird diversity. The endangered wood stork (Mycteria americana) was observed on site in both 2011 and 2012, and represents the high quality avian habitat at Hines. Several additional species observed on site, including the sedge wren, black-crowned nightheron, and pied-billed grebe, are considered sensitive species. (See Appendix Chapter 6 for a complete list of species observed in 2011 and 2012) 
During the 2011 Natural Resources Inventory, 8 species of reptiles and 5 species of amphibians were observed at the Hines Energy site. No significant differences were observed between the 2011 and 2012 herpetological survey, though three species of lizards and one species of snake was observed that was not observed in 2011. (See Appendix Chapter 6 for a complete list of species observed in 2011 and 2012)

In both April 2011 and April 2012, numerous American alligators were observed on site. The USFWS classifies the American alligator as similarity of appearance (Threatened) meaning that it is threatened due to its similarity of appearance with another listed species and is listed for its protection not because it is biologically endangered or threatened.

No threatened or endangered herbaceous or woody plant species were observed during 2011 or 2012. The plant species that were recorded during the Natural Resources Inventory are consistent with the species expected for a clay settling area in a historic phosphorus mine. The plant tissue analysis did not show a significant change in phosphous levels from 2011 to 2012 as a result of cooling pond water being pumped through the wetland. Similarly, the soil data showed little change from 2011 to 2012.

Overall, the Natural Resource Inventory showed a stable environment with little visible impact from the heated cooling pond water on the wetland system.

\section{Discussion}

Wetland degradation and losses have been dramatic throughout much of the world, including the U.S. According to the information in USGS Water Supply Paper 2425 (Dahl \& Allord, 1996), over 50\% of the 221 million acres of wetlands in the U.S. in the 1600 's had been lost to agricultural and land development conversions by the 1980's, leaving about 103 million acres of wetlands in the U.S. at that time. Most of America's remaining wetlands have been degraded through partial drainage, nutrient enrichment and other pollution, vegetation alteration, and/or invasive plant species.

\section{Water Quality Benefits}

The Hines Energy Complex has a closed-loop re-circulating cooling water system that results in increased levels of carbonates, sulfates, phosphates, calcium, and sodium. The study results demonstrated a reduction of $\mathrm{pH}$ from 9 to 7 and a significant reduction in conductivity / total dissolved solids (TDS). Evidence suggested that the dissolved solids are precipitation out, but further study of the potential water quality benefits associated with the wetland water cooling system will require further evaluation. However, the measurement of a 2-point reduction in $\mathrm{pH}$, and up to a $50 \%$ reduction in the concentrations of these dissolved chemicals, documents a low cost, and important strategy for improving and maintaining improved water quality for power plants. 


\section{SA-8 Scaling Up and Replicability at Other Power Plants}

From the research, documentation, analysis and discussions with Hines Energy Complex completed to date, the expansion of SA-8 constructed wetlands will allow for more complete, comprehensive cooling data demonstrated on a commercial scale. The underlying principles of utilizing water to cool steam cycles and provide makeup for power plants is nothing new. As of 2005, some $12.7 \%$ of thermoelectric plants used cooling reservoirs at the plant site for their primary cooling water source (USDOE/NETL, 2008), while many others use a combination of reservoirs/ponds in conjunction with rivers, streams and lakes. While this is not a new strategy, there is limited experience with the technology of wetlands and what is possible through constructed wetlands specifically designed to augment a power producer's existing water resources.

Scaling up to SA-8 will make this project an extremely viable model with great scale applicability around the country. More detailed analysis of power plant needs and wetland restoration potential should be completed and would be beneficial to expedite the process of replicating the study in other regions of the US. Further study and pilot demonstration of the strategies discussed in this report are required to confirm the breadth, overall effectiveness, and hard economics of using constructed wetlands to augment existing water resources.

The AES Team's conclusion is not intended to suggest that a strategy to employ constructed wetlands should, or even could, supplant conventional cooling and makeup water resources, or that a wetland and water harvesting strategy should or could be implemented in all locations. However, we conclude that constructed wetlands should be a mainstream strategy that can produce beneficial outcomes (e.g., regulatory, financial, public relations, additional water quantity and improved quality, and supply assurances when normal supplies are stressed) for power producers, which can mitigate the demand on traditional surface water and groundwater resources from power production. 


\section{CHAPTER 7 - FINDINGS AND CONCLUSIONS}

While further study and pilot demonstration of the strategies discussed in this report are required to confirm the breadth, overall effectiveness, and hard economics of using constructed wetlands to augment existing water resources, our Team is confident of the findings and conclusions that have emerged from this study as follows.

1. Constructed wetlands can be a practical and effective strategy used to augment water resources for makeup supply and cooling at many, but not all, thermoelectric power plant sites to help alleviate stress on existing surface water and groundwater resources, through harvesting, storing, polishing and reusing critical water resources.

Effective water harvesting (for beneficial use) from the local watersheds can lessen the stress on existing water sources and be a major new source of supply water, yet this source is not being used or even considered as part of a water resource strategy across most thermoelectric plant sites in operations or in planning today. With an effective formal cross-discipline communications strategy, these beneficial uses of constructed wetlands have the potential to become a 'mainstream' strategy for consideration and use by existing power generators, planners, and regulators in permitting new sites, and in retrofitting existing sites.

2. Constructed wetlands can have very beneficial ancillary socio-economic and ecological benefits when used effectively to compliment water resources at thermoelectric power plant sites.

While additional studies are required to further document, likely socio-economic and ecological functions of constructed wetlands at a power plant (as discussed in Chapters 3 and 4), include water harvesting / storage, flood control / mitigation, effluent cleaning / polishing, infiltration/groundwater recharge, lessening of thermal shock on existing water bodies, expanding plant and wildlife habitat and biodiversity, and possible carbon sequestration.

3. The magnitude of impact and overall economics of using constructed wetlands will be highly site specific, yet the study indicates the strategy has wide-scale potential across much of the Eastern United States.

Figures 10 and 11 along with associated discussion illustrate that the eastern half of the United States is the most favorable for application of constructed wetland because of precipitation and stormwater runoff rates being greater than potential evapotranspiration rates. 
4. The STELLA-based model developed as part of this study can be a useful tool in helping to evaluate required wetland area and ratio of watershed to wetland area for a given water resource objective or to project performance based on site operating, hydrological and climate data.

The three scenarios studies discussed in Chapter 5 illustrate an initial crosssection of possible applications using actual data for a coal fired power plant located in northern Illinois. As example, the results of the Scenario 2 model reported in Chapter 5, identified combinations of wetland area to power plant generation capacity and watershed area to wetland area necessary to maintain the discharge temperature from the wetland below a specified temperature for cooling of once through cooling water. Similarly the Scenario 3 results identified combinations of the same variables needed to maintain closed loop cooling and to keep the discharge temperature below a specified level. The STELLA model can be a useful tool in evaluating a wide range of wetland strategies at any power plant site.

5. While not studied as part of this project, a constructed wetland specifically designed to clean and polish specific effluents can serve a useful wastewater treatment/cleansing function thus providing for possible beneficial reuse at the site.

As discussed in Chapter 3 and 4 , there is a significant level of experience and study documented in the literature regarding the use of constructed wetlands for treatment of a variety of wastewater streams. Additionally, our Team has handson experience with the effective use of wetland polishing of effluents in nonpower production systems. Constructed wetlands at a power plant can be designed to meet various needs including water cooling and storage, flow buffering, and treatment / polishing of various power generation wastewater streams, and/or wastewater effluent from a nearby wastewater treatment plant to provide a significant supplementary water source.

6. There is a need for near term additional study and full scale demonstration project experience covering a wide range of sites and technologies to further document the engineering, water resource and social-economic benefits. Cross-discipline workshops are needed to stimulate the discussion, study and adoption of wetland based strategies in the power generation industry.

The findings of this project lead to the conclusion that constructed wetlands (as opposed to naturally occurring wetlands) have noteworthy potential to be a useful and important strategy to help address stresses on surface water and groundwater resources from thermoelectric power plant cooling and makeup water requirements. Even with the positive early results observed at Hines Energy Complex, there there is clearly a need for additional study and hard documentation across a wide range of power generation sites, using varying 


\section{Chapter 7}

technologies, watershed and environmental conditions, to develop hard engineering and economic models and confirm the social-economic benefits for various regions of the country.

The AES/SES team greatly appreciates the opportunity to participate in this innovative study and we thank all involved for the support provided. 


\section{REFERENCES}

\section{Chapter 1 - Introduction}

\section{Chapter 2 - Background on Issues Associated with Water Use and Power Production}

Bailey, David E., 2009, Energy and Water Interdependency Issues, Presented at NARUC Winter Joint Meeting Panel, Feb. 17, 2009.

Bistline, John, 2008, Impacts of Electric Generation Portfolio on Water Resources, Presented at Carnegie Mellon Electric Industry Seminar Series, March 26, 2008.

COOLADD, 1998, A Database of Power Plant Cooling Water Systems and Generic Chemical Additives Usage, Electric Power Research Institute, Palo Alto, CA, December 1998.

DOE, 2006, Energy Demands on Water Resources, Report to Congress on the Interdependency of Energy and Water, December 2006.

DOE/NETL, 2006, Estimating Freshwater Needs to Meet Future Thermoelectric Generation Requirements, DOE/NETL-2006/1235, August 2006.

DOE/NETL, 2008, Estimating Freshwater Needs to Meet Future Thermoelectric Generating Requirements - 2008 Update, DOE/NETL-400/2008/1339, Sept. 30, 2008.

EPRI, 2002, Water \& Sustainability (Volume 3): U.S. Water Consumption for Power Production - The Next Half Century, EPRI, Palo Alto, CA, 2002, 1006786.

Micheletti, W.C. and Burns, J.M., 2002, Emerging Issues and Needs in Power Plant Cooling Systems, NTEL Conference Proceedings: Electric Utilities and Water: Emerging Issues and R\&D Needs, July 23, 2002.

Maulbetsch, J.S., 2005, Power Plant Cooling -- What are the tradeoffs?, Presented at California State Water Resources Control Board Workshop, Oakland, CA, Dec. 7, 2005.

USGS, 1998, Estimated Use of Water in the United States in 1995, USGS Circular 1200, 1998.

USGS, 2004, Estimated Use of Water in the United States in 2000, USGS Circular 1268, March 2004. 
Veil, John, 2002, Overview of Regulations affecting the electric Utility Industry, Presented at NETL workshop, July 23, 2002.

\section{Chapter 3 - Science and History of Wetlands}

Anderson, J.R., E.E. Hardy, J.T. Roach, and R.E. Witmer. 1976. A Land Use and Land Cover Classification System for Use with Remote Sensor Data. U.S. Department of the Interior, Geological Survey Professional Paper 964.

Cowardin, L.M., V. Carter, F.C. Golet, and E.T. Laroe. 1979. Classification of wetlands and deepwater habitats of the United States. U.S. Department of Interior, office of Biological Services Fish and Wildlife Service FWS/OBS-79/31.

Foster, P.D. Robillard, and D.W. Lehning. 1995. WATERSHEDSS: Water, Soil and Hydro-Environmental Decision Support System, http://h2osparc.wq.ncsu.edu.

Dahl, T. E. \& Allord, G. J., 1996, "History of Wetlands in the Conterminous United States", in Judy D. Fretwell, John S. Williams, and Phillip J. Redman (eds.) National Water Summary on Wetland Resources, USGS Water Supply Paper 2425, U.S. Geological Survey, Washington, D.C., pp. 19-26. http://water.usgs.gov/nwsum/WSP2425/history.html

Gilliam, J.W. 1994. Riparian wetlands and water quality. Journal of Environmental Quality 23:896-900.

Hemond, H.F.and J. Benoit. 1988. Cumulative impacts on water quality functions of wetlands. Environmental Management 12(5):639-653.

Johnston, C.A. 1991. Sediment and nutrient retention by freashwater wetlands: effects on surface water quality. Critical review of Environmental Control 21:491-565.

Osmond, D.L., D.E. Line, J.A. Gale, R.W. Gannon, C.B. Knott, K.A. Bartenhagen, M.H. Turner, S.W. Coffey, J. Spooner, J. Wells, J.C. Walker, L.L. Hargrove, M.A. Foster, P.D. Robillard, and D.W. Lehning. 1995. WATERSHEDSS: Water, Soil and HydroEnvironmental Decision Support System, http://h2osparc.wq.ncsu.edu.

Rodgers, J.H., Jr, and Castle, J.W., An Innovative System for the Efficient and Effective Treatment of Non-traditional Waters for Reuse in Thermoelectric Power Generation, Final Technical Report, United States Department of Energy Award \#DE-FG2605NT42535, November 28, 2008.

Shaw, S.P. and C.G. Fredine. 1956. Wetlands of the United States. U.S. fish Wildl. Serv., Circular 39. 
Taylor, J.R., M.A. Cardamone, W.J. Mitsch. 1990. Bottomland hardwood forests: their functions and values, Ch 2 in Gosselink et al. 1990. Ecological Processes and Cumulative Impacts. Lewis Publishers: Chelsea, MI.

Weller, M.W. 1981. Freshwater Marshes, Ecology and Wildlife Management. Minneapolis: university of Minnesota Press.

\section{Chapter 4 - Opportunities and Challenges Associated with Using Wetlands for Power Plant Water Storage and / or Cooling}

Brix, H., 1993, "Wastewater Treatment in Constructed Wetlands: System Design, Removal Processes, and Treatment Performance," Chapter 2, pp. 9-22, in G.A. Moshiri (Ed.), Constructed Wetlands for Water Quality Improvement, Boca Raton: Lewis Publishers.

Kadlec, Robert H., and Robert L. Knight., 1996, Treatment Wetlands, Chelsea: Lewis Publishers.

Knight, R.L., Ruble, R.W., Kadlec, R.H., and S.C. Reed, 1993, "Database: North American Wetlands for Water Quality Treatment. Phase II Report," Prepared for U.S. EPA, September 1993.

Minnesota Municipal Power Agency. 2007. Quarterly Report - Q3 2007.

Reed, Sherwood C., Ronald W. Crites, and E. Joe Middlebrooks, 1995, Natural Systems for Waste Management and Treatment 2nd ed., San Francisco: McGraw-Hill.

Rodgers, J.H., Jr, and Castle, J.W., An Innovative System for the Efficient and Effective Treatment of Non-traditional Waters for Reuse in Thermoelectric Power Generation, Final Technical Report, United States Department of Energy Award \#DE-FG2605NT42535, November 28, 2008.

SaskPower. 2003. SaskPower Constructed Wetland Brochure.

\section{Thermal Tolerance of Aquatic Biota}

1. Abel, P.D. 1996. Water pollution biology-Second Edition. The Northumbrian Water Ecology Center, University of Sunderland, Sunderland, UK. Taylor \& Francis Group. Bristol, PA.

2. Adams, J.R. 1969. Ecological investigations around some thermal power stations in California tidal waters source. Chesapeake Science, Vol. 10, No. 3/4, Proceedings of the 2nd Thermal Workshop of the U.S. International Biological Program (Sep. - Dec., 1969), pp. 145-154. Estuarine Research Federation. 
3. Alden, R.W. 1979. Effects of a thermal discharge on the mortality of copedpods in a subtropical estuary. 1979. Environmental Pollution. Applied Science Publishers Ltd, England. Great Britain.

4. Armour, C.L. 1991. Guidance for evaluating and recommending temperature regimes to protect fish. U.S. Fish and Wildlife Service. National Ecology Resource Center. Fort Collins, CO.

5. Asaeda, T., V.K. Trung, J. Manatunge and T. Van Bon. 2001. Modeling macrophyte-nutrient-phytoplankton interactions in shallow eutrophic lakes and the evaluation of environmental impacts. Ecological Engineering 16:341-357.

6. Balkuvien, G. and B. Pernaraviité. 1997. Growth rates of roach (Rutilus rutilus $(L))$ in a cooling water reservoir under different thermal conditions. Institute of Ecology, Akademijos 2, Vilnius 2600 . Lithuania.

7. Barnett, P.R.O. 1972. Effects of warm water effluents from power stations on marine life. Proceedings of the Royal Society of London. Series B, Biological Sciences, Vol. 180, No. 1061. A Discussion on Freshwater and Estuarine Studies of the Effects of Industry (Mar. 21, 1972), pp. 497-509. The Royal Society.

8. Barton, C., E.A. Nelson, R.K. Kolka, K.W. McLeod, W.H. Conner, M. Lakly, D. Martin, J. Wigginton, C.C. Trettin and J. Wisniewski. 2000. Restoration of a severely impacted riparian wetland system - the Pen Branch project. Ecological Engineering 15:S3-S15. Guest editorial.

9. Becker, C.D. 1973. Columbia River thermal effects study: reactor effluent problems. Water Pollution Control Federation. Vol. 45, No. 5:850-869. Water Environment Federation.

10. Bing, J.Z., J.N. Zeng, Q.Z. Chen, Y.J. Huang, Y.B. Liao, X.Q. Xu and P. Zheng. 2009. Potential impact of rising seawater temperature on copepods due to coastal power plants in subtropical areas. Journal of Experimental Marine Biology and Ecology 368:196-201.

11. Bowers, C.F., H.G. Hanlin, D.C. Guynn Jr., J.P. McLendon and J.R. Davis. 2000. Herpetofaunal and vegetational characterization of a thermally-impacted stream at the beginning of restoration Ecological Engineering 15:SI01-SI14.

12. Boyes, S. and M. Elliott. No date. Thermal pollution - Turkey Point Nuclear Power Generating Station, South Florida - Case Study. Chemgaroo. URL: http://www.chemgapedia.de/vsengine/vlu/vsc/en/ch/16/uc/vlus/thermalpollution.vlu/P age/vsc/en/ch/16/uc/pollution/casestudies/thermal/thermalturkey.vscml.html.

13. Burton, D.T., L.B. Richardson, S.L. Margrey and P.R. Abell. 1976. Effects of low $\Delta \mathrm{T}$ powerplant temperatures on estuarine invertebrates. Water Pollution Control Federation, Vol. 48, No. 10:2259- 2272. 
14. Cairns, Jr., J. 1971. Thermal pollution: a cause for concern. Water Pollution Control Federation, Vol. 43, No. 1:55-66.

15. Cheper, N.J. 1980. Thermal tolerance of the isopod Lirceus brachyurus (Crustacea:Isopoda). American Midland Naturalist, Vol. 104, No. 2:312-318. The University of Notre Dame.

16. Cole, R.A. and J. E. Kelly. 1778. Zoobenthos in thermal discharge to Western Lake Erie. Water Pollution Control Federation, Vol. 50, No. 11:2509-2521. Water Environment Federation.

17. Cox, D.K. and J.J. Beauchamp. 1982. Thermal resistance of juvenile crayfish, Cambarus bartoni (Fabricius): experiment and model. American Midland Naturalist, Vol. 108, No. 1:187-193. The University of Notre Dame.

18. Daufresne, M., M. C. Roger, H. Capra and N. Lamouroux. 2003. Long-term changes within the invertebrate and fish communities of the Upper Rhone River: effects of climatic factors. Global Change Biology 10:124-140, doi: 10.1046/j.15298817.2003.00720.x.

19. Davenport, J., P.R.O. Barnett and R.J. McAllen. 1997. Environmental tolerances of three species of the Harpacticoid Copepod genus. Thermal Effects. Tigriopus. J. Mar. Biol. Assoc. U.K. (G.B.), 77, 3.

20. Dejonckheere, J. P. Van Dijck and H. Van de Voorde. 1975. The effect of thermal pollution on the distribution of Naegleria fowleri. J. Hyg., Camb. 75, 77. Great Britain.

21. Drost-Hansen, W. 1969. Allowable thermal pollution limits: A Physico-Chemical approach. Chesapeake Science 10:281-288. Proceedings of the 2nd Thermal Workshop of the U.S. International Biological Program. Estuarine Research Federation.

22. Eaton, J.G., J.H. McCormick, H.G. Stefan and M. Hondzo. 1995. Extreme value analysis of a fish/temperature field database. Ecological Engineering 4:289-305.

23. El-Din, N.M. 2004. Impact of cooling water discharge on the bethic and planktonic pelagic fauna along the coastal waters of Qatar (Arabian Gulf). Egyptian Journal of Aquatic Research, Vol 30(A):150-159.

24. Encina, L., A.R. Ruiz and C.G. Lorencio. 2008. Distribution of common carp in a Spanish reservoir in relation to thermal loading from a nuclear power plant. Journal of Thermal Biology 33:444-450.

25. Encyclopedia.com. 2004. A Dictionary of Biology. "upper critical temperature". URL: www.encyclopedia.com (Accessed 2009). 
26. Esch, G.W. and R.W. McFarlane. 1976. Thermal ecology II. Savannah River Ecology Laboratory, Institute of Ecology, University of Georgia. Technical Information Center, Energy Research and Development Administration.

27. Foerster, J.W., F.R. Trainor and J.D. Buck. 1974. Thermal effects on the Connecticut River: psychology and chemistry. Water Pollution Control Federation, Vol. 46, No. 9:2138-2152. Water Environment Federation.

28. Fox, J.L. and M.S. Moyer. 1973. Some effects of a power plant on marine microbiota. Chesapeake Science, Vol. 14, No. 1:1-10. Estuarine Research Federation.

29. Gibbons, J.W. and R.R. Sharitz. 1981. Thermal ecology: Environmental teachings of a nuclear reactor site. BioScience, Vol. 31, No. 4:293-298.

30. Gory, R.L. and J. W. Nauman. 1969. Epifauna and thermal additions in the Upper Patuxent River. Estuary Chesapeake Science Vol. 10, No. 3 \& 4:210-217. U. S. Geological Survey. Washington, D.C.

31. Gutierrez-Estrada, J.C. and I. Pulido-Calvo. 2007. Water temperature regimen analysis of intensive fishfarms associated with cooling effluents from power plants. Biosystems Engineering 96 (4):581-591.

32. Haag, R.W. and P.R. Gorham. 1977. Effects of thermal effluent on standing crop and net production of Elodea canadensis and other submerged macrophytes in Lake Wabamun, Alberta. The Journal of Applied Ecology, Vol. 14, No. 3:835-851. British Ecological Society.

33. Hansen, W.D. 1969. Allowable thermal pollution limits: a physico-chemical approach. Chesapeake Science. Vol. 10, No. 3/4, Proceedings of the 2nd Thermal Workshop of the U.S. International Biological Program (Sep. - Dec., 1969), pp. 281288. Estuarine Research Federation.

34. Hauer, F.R. and A.C. Benke. 1991. Rapid growth of snag-dwelling chironomids in a blackwater river: the influence of temperature and discharge. Journal of the North American Benthological Society, Vol. 10, No. 2:154-164. The North American Benthological Society.

35. Haynes, J.M., G.P. Gerber and J.K. Buttner. 1989. Response of sport fishes to thermal discharges into the Great Lakes: is Somerset station, Lake Ontario, different? Journal of Great Lakes Research 15(4):709-718. International Association of Great Lakes Research.

36. Hogg, I.D., D. D. Williams, J. M. Eadie and S. A. Butt. 1995. The consequences of global warming for stream invertebrates: a field simulation. ThermB. id. Vol. 20, No. 1/2:199-2061. Elsevier Science Ltd. Great Britain. 
37. Houston, A.H. 1982. Thermal effects upon fishes. National Research Council. Canada. NRCC No. 18566. Associate Committee on Scientific Criteria for Environmental Quality.

38. Huizinga, H.W. and G.L. McLaughlin. 1990. Thermal ecology of Naegleria fowleri from a power plant cooling reservoir. Applied and Environmental Microbiology 56:2200-2205. American Society for Microbiology.

39. Hyfield, E.C.G., J. Day, I. Mendelssohn and G. P. Kemp. 2007. A feasibility analysis of discharge of non-contact, once-through industrial cooling water to forested wetlands for coastal restoration in Louisiana. Ecological Engineering 29 (17).

40. Jiang, Z., J. Zeng, Q. Chen, Y. Huang, X. Xu, Y. Liao, L. Shou and J. Liu. 2008. Tolerance of copepods to short-term thermal stress caused by coastal power stations. Journal of Thermal Biology 33:419-423.

41. Jiang, Z., J. Zeng, Q. Chen, Y.Huang, Y.Liao, X. Xu and P. Zheng. 2009. Potential impact of rising seawater temperature on copepods due to coastal power plants in subtropical areas. Journal of Experimental Marine Biology and Ecology 368:196-201.

42. Lakly, M.B. and J.V. McArthur. 2000. Macroinvertebrate recovery of a postthermal stream: habitat structure and biotic function. Ecological Engineering 15:S87S100.

43. Lewis, D.H. and R.D. Roer. 1988. Thermal preference in distribution of blue crabs, Callinectes sapidus, in a power plant cooling pond. Journal of Crustacean Biology, Vol. 8, No. 2:283-289. The Crustacean Society.

44. Logan, D.T. and D. Maurer. 1975. Diversity of marine invertebrates in a thermal effluent. 1975. Water Pollution Control Federation. Vol. 47, No. 3, Part I:515-523. Water Environment Federation.

45. Mas, W.Y., C.S.W Kueh, G.W.L. Chiu, S.R. Wild and J.Y. Yip. 1998.

Environmental management of coastal cooling water discharges in Hong Kong. Water Science and Technology.

46. Mason, C.F. 1996. Biology of freshwater pollution-Third Edition. Department of Biology, University of Essex. Longman, England.

47. McMahon, R.F. 1975. Effects of artificially elevated water temperatures on the growth, reproduction and life cycle of a natural population of Physa virgata (Gould). Ecology, Vol. 56, No. 5:1167-1175. Ecological Society of America. 
48. Mitchell, J.S., R.C. Briley and R.W. Knapton. 1996. Abundance of Dreissena polymorpha and Dreissena bugensis in a warmwater plume: effects of depth and temperature. Can. J. Fish. Aquat. Sci, 53, 1705.

49. Morin, R.P. and M.F. Hirshfield. 1984. Thermal effects on the life history of the mummichog: Fundulus heteroclitus. Proceedings of the Academy of Natural Sciences of Philadelphia, Vol. 136:218-228. Academy of Natural Sciences.

50. Nedeaua, E.J., R.W. Merritta and M.G. Kaufmanb. 2003. The effect of an industrial effluent on an urban stream benthic community: water quality vs. habitat quality. Environmental Pollution 123:1-13.

51. Nelson, E.A., N.C. Dulohery, R.K. Kolka and W.H. McKee Jr. 2000. Operational restoration of the Pen Branch bottomland hardwood and swamp wetlands - the research setting. Ecological Engineering 15:S23-S33.

52. Olla, B.L. and A.L. Studholme. 1971. The effect of temperature on the activity of bluefish, Pomatomus saltatrix L. Biological Bulletin, Vol. 141, No. 2:337-349. Marine Biological Laboratory.

53. Perry, S.A., W.B. Perry and J.A. Stanford. 1987. Effects of thermal regime on size, growth rates and emergence of two species of stoneflies (Plecoptera: Taeniopterygidae, Pteronarcyidae) in the Flathead River, Montana. American Midland Naturalist, Vol. 117, No. 1:83-93. The University of Notre Dame.

54. Pilon, J. and L. Santamaria. 2002. Clonal variation in the thermal response of the submerged aquatic macrophyte Potamogeton pectinatus. Netherlands Institute of Ecology, Centre for Limnology, Rijksstraatweg 6, 3631 AC Nieuwersluis, The Netherlands Journal of Ecology 90:141-152. British Ecological Society, Blackwell Science Ltd.

55. Proffitt, M.A. 1969. Effects of heated discharge upon aquatic resources of white river at Petersburg, Indiana. Water Resources Research Center, Report of Investigation No. 3. February, 1969. Bloomington, Indiana.

56. Rausch, C.M., P.L. Starkweather, and F. van Breukelen. 2008. One year in the life of Bufo punctatus: annual patterns of body temperature in a free-ranging desert anuran. Naturwissenschaften 95:531-535.

57. Rolan, R.G. 1974. The Fresh-water polychaete, Manayunkia speciosa, in a thermal discharge channel, Cleveland Harbor, Lake Erie. American Midland Naturalist, Vol. 92, No. 1:207-213. The University of Notre Dame

58. Sandstrom, M., I. Abrhamsson, J. Anderson and M. Vetemaa. 1997. Temperature effects on spawning and egg development in Eurasian perch. Journal of Fish Biology 51:1015-1024. 
59. Schiel, D. R., J.R. Steinbeck and M.S. Foster. 2004. Ten years of induced ocean warming causes comprehensive changes in marine benthic communities. Ecology, Vol. 85, No. 7:1833-1839. Ecological Society of America.

60. Smith, R.K and K.D. Fausch. 1997. Thermal tolerance and vegetation preference of Arkansas Darter and Johnny Darter from Colorado Plains streams. Transaction of the American Fisheries Society 126:676-686. American Fisheries Society.

61. Snoeijs, P.J.M. 1989. Effects of increasing water temperatures and flow rates on epilithic fauna in a cooling- water discharge basin source. The Journal of Applied Ecology, Vol. 26, No. 3:935-956. British Ecological Society.

62. Snyder, G.R. and T.H. Blahm. 1971. Effects of increased temperature on coldwater organisms. Water Pollution Control Federation, Vol. 43, No. 5:890-899. Water Environment Federation.

63. Tison, D.L., E. W. Wilde, D. H. Pope and C. B. Fliermans. 1981. Productivity and species composition of algal mat communities exposed to a fluctuating thermal regime. Microbial Ecology 7:151-165.

64. Ultsch, G.R., D.F. Bradford and J. Freda. 1999. Physiology: coping with the environment. R.W. McDiarmid and R. Altig (eds.). Tadpoles: The Biology of Anuran Larvae. 189-214. University of Chicago Press, Chicago, IL.

65. U.S. Environmental Protection Agency. 1986. Quality Criteria for Water - 1986. Office of Water Regulations and Standards, Washington DC. EPA 440/5-86-001.

66. Voelz, N.J., N. L. Poff and J. V. Ward. 1994. Differential effects of a brief thermal disturbance on caddisflies (Trichoptera) in a regulated river. American Midland Naturalist, Vol. 132, No. 1:173-182. The University of Notre Dame.

67. Welch, E.B. and J.M. Jacoby. 2004. Pollutant Effects in Freshwater: Applied Limnology-Third Edition. Spoon Press. Taylor \& Francis Group. London and New York.

68. Wellborn, G.A. and J.V. Robinson. 1996. Effects of a thermal effluent on macroinvertebrates in a Central Texas reservoir. American Midland Naturalist, Vol. 136, No. 1:110-120. The University of Notre Dame.

69. White, J.W., W.S. Woolcott and W.L. Kirk. 1977. A study of the fish community in the vicinity of a thermal discharge in the James River, Virginia. Chesapeake Science, Vol. 18, No. 2:161-171. Estuarine Research Federation.

70. Willmer, P., G. Stone and I.A. Johnston. 2000. Environmental physiology of animals. 
71. Wood, C.M. and D.G. McDonald. 1997. Global warming - implications for freshwater and marine fish. Cambridge University Press-United Kingdom.

\section{Chapter 5 - Wetlands Water Cooling - Evaluation Model}

Anderson, Jay. "Global Cloud Maps." Eclipser: Climatology and Maps for the Eclipse Chaser. 2009. University of Manitoba. 22 Jan. 2010. URL: http://home.cc.umanitoba.ca/ jander/clouds/globalclouds.html

Chapra, S.C., Pelletier, G.J. and Tao, H. 2007. QUAL2K: A Modeling Framework for Simulating River and Stream Water Quality, Version 2.07: Documentation and User Manual. Civil and Environmental Engineering Dept., Tufts University, Medford, MA.

EPRI, 2002, Water \& Sustainability (Volume 3): U.S. Water Consumption for Power Production - The Next Half Century, EPRI, Palo Alto, CA, 2002, 1006786.

French, R.H., McCutheon, S.C. 1989. Water Quality Modeling: Volume 1 Transport \& Surface Exchange in Rivers. CRC Press, Boca Raton, FL.

Ryan, P. J., Harleman, D.R. and Stolzenbach, K.D. 1974. Surface Heat Loss From Cooling Ponds. Water Resources Research, 10(5): 930-938.

USDA-NRCS. 1986. Technical Release 55: Urban Hydrology for Small Watersheds.

\section{Chapter 6 - Wetland Water Cooling Demonstration Project}

Anderson, J.R., E.E. Hardy, J.T. Roach, and R.E. Witmer. 1976. A Land Use and Land Cover Classification System for Use with Remote Sensor Data. U.S. Department of the Interior, Geological Survey Professional Paper 964.

Bailey, David E., 2009, Energy and Water Interdependency Issues, Presented at NARUC Winter Joint Meeting Panel, Feb. 17, 2009.

Brix, H., 1993, "Wastewater Treatment in Constructed Wetlands: System Design, Removal Processes, and Treatment Performance," Chapter 2, pp. 9-22, in G.A. Moshiri (Ed.), Constructed Wetlands for Water Quality Improvement, Boca Raton: Lewis Publishers. 


\section{Chapter 7 - Findings and Conclusions}

Cowardin, L.M., V. Carter, F.C. Golet, and E.T. Laroe. 1979. Classification of wetlands and deepwater habitats of the United States. U.S. Department of Interior, Office of Biological Services Fish and Wildlife Service FWS/OBS-79/31.

Mitsch, W..J. \& J.G. Gosselink. 1993. Wetlands. John Wiley and Sons, Inc., New York.

Niering, W.A. 1998. Wetlands. Alfred A. Knopf, Inc., New York.

Novitski, R.P., R.D. Smith, and J.D. Fretwell. 1996. Restoration, Creation, and Recovery of Wetlands; Wetland Functions, Values, and Assessment. In Fretwell, J.D, J.S Williams, and P.J. Redman, National water Summary on Wetland Resources. USGS Water Supply Paper 2425.

Osmond, D.L., D.E. Line, J.A. Gale, R.W. Gannon, C.B. Knott, K.A. Bartenhagen, M.H. Turner, S.W. Coffey, J. Spooner, J. Wells, J.C. Walker, L.L. Hargrove, M.A. Foster, P.D. Robillard, and D.W. Lehning. 1995. WATERSHEDSS: Water, Soil and HydroEnvironmental Decision Support System, URL: http://h2osparc.wq.ncsu.edu.

United States Environmental Protection Agency. 1995. Wetlands fact sheets. EPA 843F-95-001. Office of Water, Office of Wetlands, Oceans and Watersheds.

United States Environmental Protection Agency. 1995b. America's Wetlands: Our Vital Link Between Land and Water. EPA 843-K-95-001, Washington D.C. Office of Water, Office of Wetlands, Oceans and watersheds.

United States Environmental Protection Agency. 2001. Functions and Values of Wetlands. EPA 843-F-01-002c. Office of Water, Office of Wetlands, Oceans and Watersheds.

United States Environmental Protection Agency. 2008. Wetland Types. URL: http://www.epa.gov/owow/wetlands/types.

United States Environmental Protection Agency. 2009. Wetlands - Status and Trends. URL: http://www.epa.gov/wetlands/vital/status.html

US DOE/EIA (Energy Information Agency). 2005, Form EIA-767: Annual Steam Electric Power Plant Operation and Design Data. 2005 data. http://www.eia.doe.gov/cneaf/electricity/page/eia767.html

US DOE/NETL, 2009. Water Requirements for Existing and Emerging Thermoelectric Plant Technologies, DOE/NETL-402/080108, August 2008 (revised April 2009). 


\section{APPENDICES}

\section{Chapter 1 - Introduction}

Table A. Water Balance for Typical 600 MW PC Unit, Wet FGD.

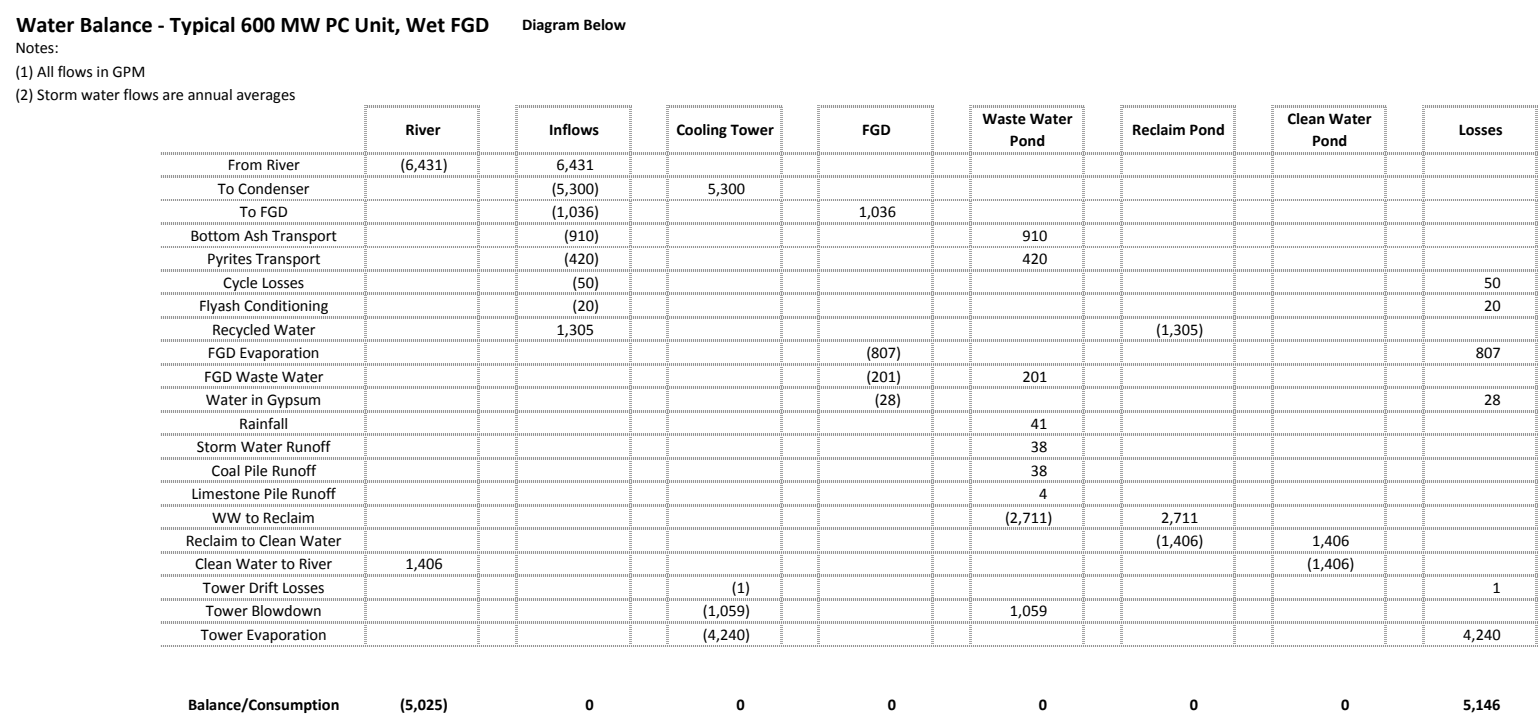

Source: American Electric Power, 2010 - aep.com.

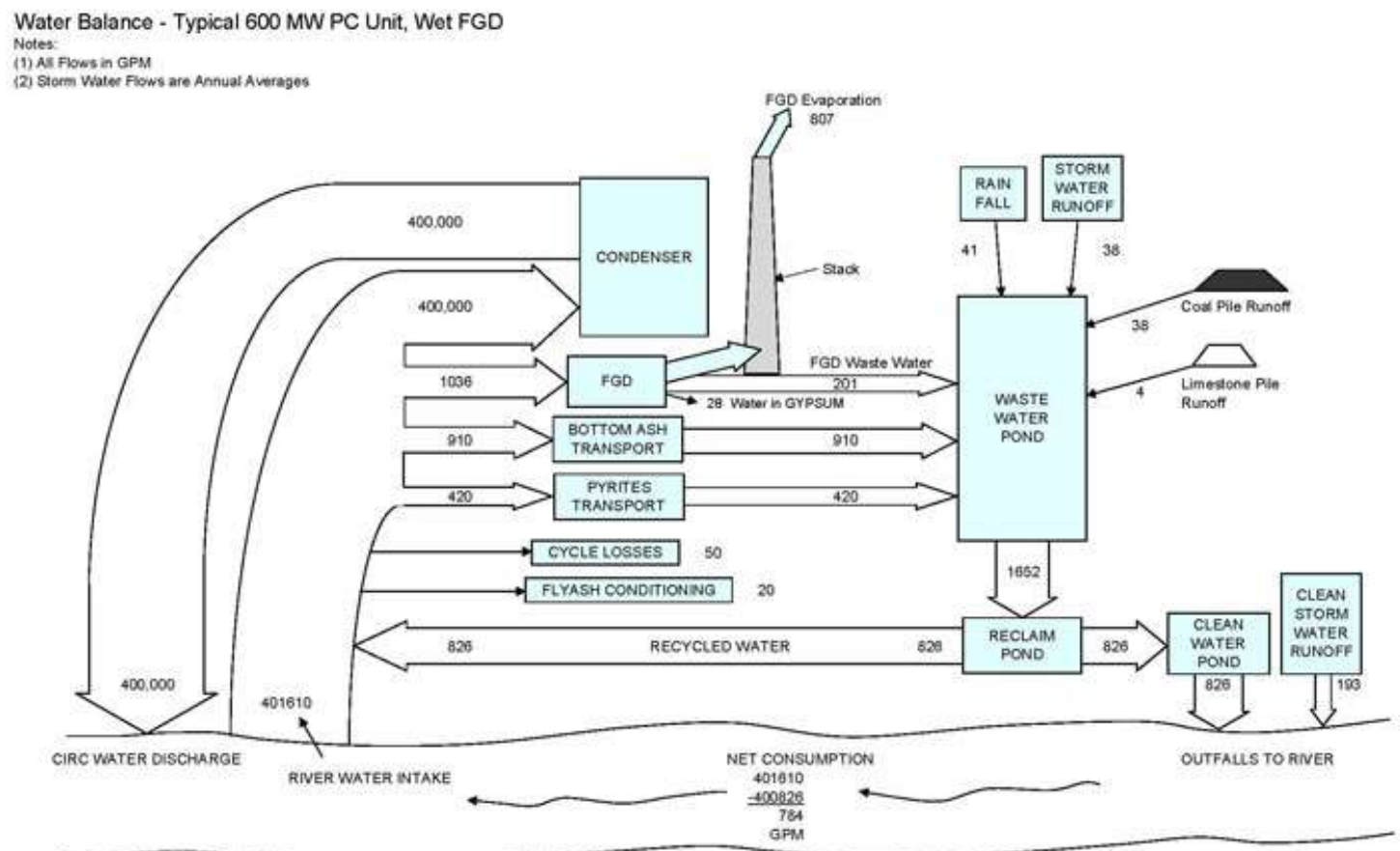


Water Balance - Typical 600 MW PC Unit, Wet FGD

Notes:

(1) All Flows in GPM

(2) Storm Water Flows are Annual Averages COOLING TOWER

COOLING TOWER
EVAPORATION

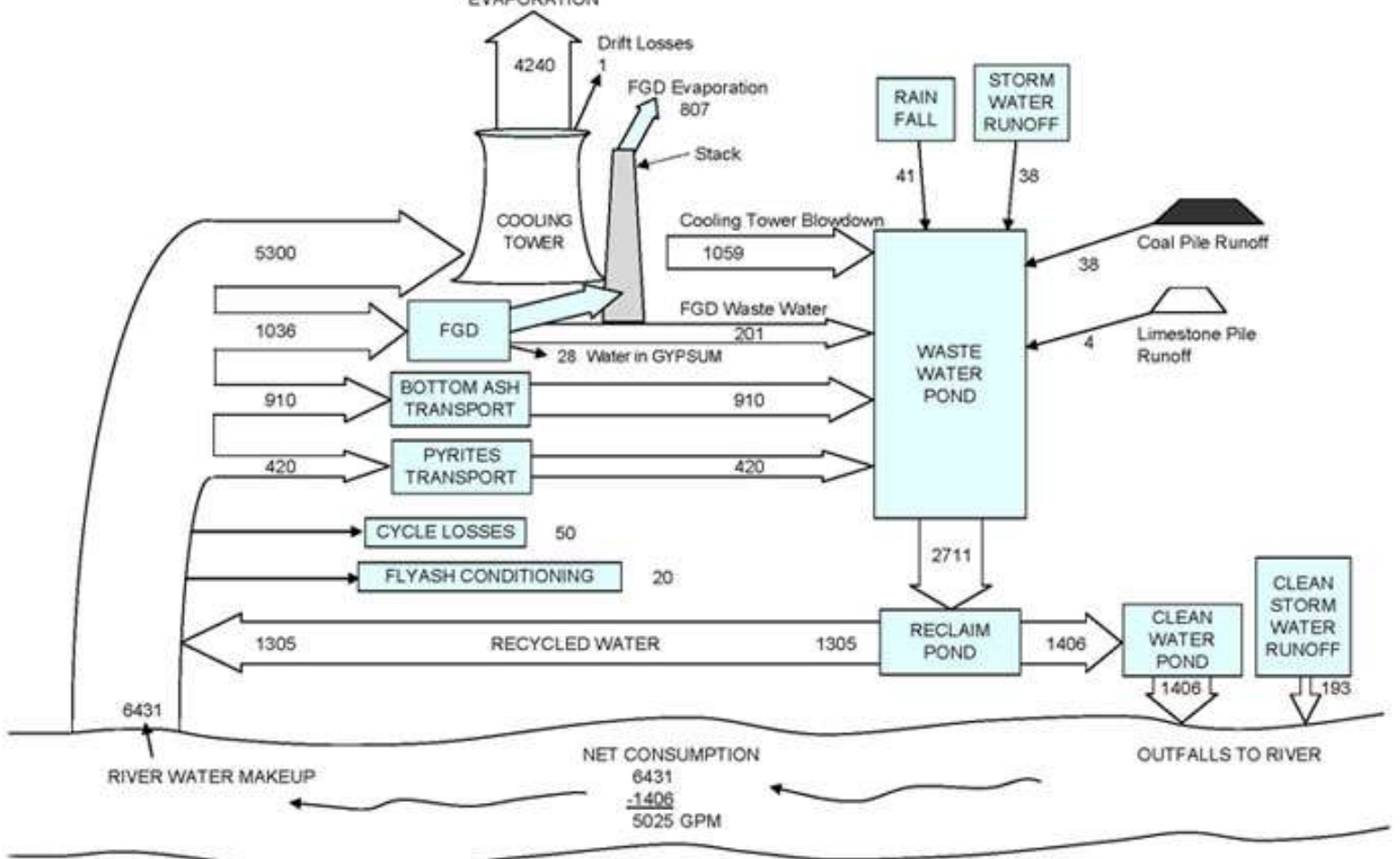

Source: American Electric Power, 2010 - aep.com.

Figures A and B. Water Balance for Typical 600 MW units with FGD (open and closed systems). 


\title{
Chapter 2 - Background on Issues Associated with Water Use and Power Production
}

\section{Table B. Fossil Fuel Steam Power Plants with Cooling Ponds in 2005.}

\author{
Plants with Once Through Cooling with Cooling Pond(s) or Canal(s)
}

Utility

1) Ameren Energy Generating $\mathrm{Co}_{0}$

2) Kansas City Power $\&$ Light $\mathrm{Co}$

3) Lower Colorado River Authority

4) Minnkota Power Coop Inc

5) Nebraska P ublic Poner District

6) Northern States Power Co

7) Southern Illinois Power Coop

8) Virginia Eledric \& Pomer $\mathrm{Co}$

9) TXU Electric Co

10) Kansas City Power \& Light Co

11) Springfield City of

12) TXU Electric $\mathrm{Co}$

13) TXU Electric Co

14) TXU Electric $\mathrm{Co}$

15) Kansas City Power \& Light $\mathrm{Co}$

16) Springfield City of

17) TXU Electric Co

18) TXU Electric Co

19) ExTeXLaP orte LP

20) TXU Electric Co

21) EXTeXLaP orte LP

22) Entergy Mississippi Inc

23) Southwestem Eledric Power Co

24) Texas Genco

25) Texas Genco

26) $\mathrm{AEP}$ Texas North Co

27) $\mathrm{AEP}$ Texas North Co

28) AEP Texas North Co

29) AEP Texas North Co

30) TXU Electric Co

31) TXU Electric $\mathrm{Co}$

32) TXU Electric $\mathrm{Co}$

33) TXU Electric Co

34) TXU Electric Co

35) TXU Electric $\mathrm{Co}$

36) TXU Electric Co

37) TXU Electric Co

St Louis, MO
Kansas City, MO
Austin, TX
Grand Forks, ND
Colum bus, NE
Minneapolis, MN
Marion, IL
Richmond, VA
Dallas, TX
Kansas City, MO
Springfield, IL
Dallas, TX
Dallas, TX
Dallas, TX
Kansas City
Springfield
Dallas, TX
Dallas, TX
Dallas, TX
Dallas, TX
Fort Worth, TX
The Woodlands, TX
Shreveport, LA
Houston, TX
Houston, TX
Abilene, TX
Abilene, TX
Abilene, TX
Abilene, TX
Dallas, TX
Dallas, TX
Dallas, TX
Dallas, TX
Dallas, TX
Dallas, TX
Dallas, TX
Dallas, TX

Newton

La Cygne

F ayette P ower Projed

Milton $\mathrm{R}$ Young

Gerald Gentleman

Black Dog

Marion

wt Storm

Big Brown

Montrose

Dallman

Lake Hubbard

Martin Lake

Monticello

Montrose

Dallman

Lake Hubbard

Graham

Mountain Creek

North Lake

Handley

Rex Brown

KnoxLee

Cedar Bayou

Cedar Bayou

Paint Creek

Paint Creek

San Angelo

Fort Phantom

Eagle Mountain

Morgan Creek

Lake Creek

Stryker Creek

Tradinghouse

Trinidad

Valley

Decordova Steam

Eledric Station
Newton, IL

La Cygne, KS

La Grange, TX

Center, ND

Sutherland, NE

Burnsville, MN

Marion,IL

Mt Storm, WV

$F$ airfield, $T X$

Clinton, $M O$

Spring field, IL

Mesquite, TX

Tatum, TX

Mt. Pleasant, $T X$

Clinton, MO

Spring field, IL

Mesquite, $T X$

Graham, TX

Dallas, $T X$

Dallas, $T X$

Fort Worth, TX

Jackson, MS

Longview, $T X$

Eldon, TX

Eldon, $T X$

Haskell, $T X$

Haskell, TX

San Angelo, TX

Abilene, TX

Saginaw, $T X$

Colorado City, TX

Riesal, TX

Rusk, TX

Waco, $T X$

Trinidad, TX

Savoy, TX

Granbury 
Plants with Recirculating Cooling with Cooling Pond(s) or Canal(s)

Utility

38) Eryan City of

39) Progress Energy Carolinas Inc

40) Progress Energy Carolinas Inc

41) Progress Energy Carolinas Inc

42) Progress Energy Carolinas Inc

43) Progress Energy Carolinas Inc

44) Cleco Power LLC

45) Topaz Power Group LLC

46) Central Power \& Lime Inc

47) Detroit Edison Co

48) Dynegy Mid west Generation Inc

49) Florida $P$ over \& Light $C_{0}$

50) Florida $P$ over $\&$ Light $C o$

51) Florida $P$ over $\&$ Light $C o$

52) Entergy Gulf States Inc

53) Loner Colorado River Authority

54) Midmest Generations EME LLC

55) Mississippi Power Co

56) Oklahom a Gas \& Eledric $\mathrm{Co}$

57) Oklahom a Gas \& Eledric $\mathrm{Co}$

58) Otter Tail Power Co

59) Portland General Electric Co

60) Public Service Co of Colorado

61) PSI Energy Inc

62) Public Service Co of Oklahoma

63) San Antonio Public Service Bd

64) San Antonio Public Service Bd

65) San Antonio Public Service Bd

66) San Antonio Public Service Bd

67) Sierra Pacific Power $\mathrm{Co}$

68) Southwestern Electric P over Co

69) Southwestern Electric P over $\mathrm{Co}$

70) Southmestern Electric P oner Co

71) Midland Cogeneration Venture

72) Texas Municipal P over Agency

73) Texas Genco

74) Alcoa Inc

75) Arizona Public Service $C o$

76) Arizona Public Service $C o$

77) Dom inion Energy Services Co

78) Empire Distrid Electric $\mathrm{Co}$

79) Hoosier Enerav R E C Inc

\begin{tabular}{|c|c|}
\hline Eryan, $\mathrm{TX}$ & Dansby \\
\hline Raleigh, NC & Asheville \\
\hline Raleigh, NC & Lee \\
\hline Raleigh, NC & L V Sutton \\
\hline Raleigh, NC & WHWeatherspoon \\
\hline Raleigh, NC & H B Robinson \\
\hline Pineville, LA & Rodemacher \\
\hline Austin, TX & Coleto Creek \\
\hline Brooksville, FL & Central Pover \& Lime \\
\hline Detroit, $M \mid$ & Greenmood \\
\hline Decatur, IL & Baldwin Energy Complex \\
\hline Juno Beach, FL & Turkey Point \\
\hline Juno Beach, FL & Manatee \\
\hline Juno Beach, FL & Martin \\
\hline The Woodlands, TX & Lewis Creek \\
\hline Austin, TX & Sim Gideon \\
\hline Chicago, IL & Pomerton \\
\hline Gulfport, MS & Victor J Daniel Jr \\
\hline Oklahom a City, OK & Seminole \\
\hline Oklahom $\mathrm{a}, \mathrm{OK}$ & Sooner \\
\hline Fergus Stone, MN & Big Stone \\
\hline Portland, OR & Boardman \\
\hline Denver, CO & Valm ont \\
\hline Plainfield, IN & Gibson \\
\hline Tulsa, OK & Comanche \\
\hline San Antonio, TX & OW Sommers \\
\hline San Antonio, TX & V H Braunig \\
\hline San Antonio, TX & J T Deely \\
\hline San Antonio, TX & Arthur Von Rosenberg \\
\hline Reno, NV & Fort Churchill \\
\hline Shreveport, LA & Arsenal Hill \\
\hline Shre veport, LA & Flint Creek \\
\hline Shre veport, LA & Pirkey \\
\hline \multirow[t]{2}{*}{ Midland, MI } & Midland Cogeneration \\
\hline & Ventrure \\
\hline Eryan, TX & Gibbons Creek \\
\hline Houston, TX & WAP arish \\
\hline Pittsburgh, PA & Sandow Station \\
\hline Phoenix, AZ & Cholla \\
\hline Phoenix, AZ & Four Corners \\
\hline Kincaid, IL & Kincaid Generation LLC \\
\hline Joplin, MO & Asbury \\
\hline Bloom inaton. IN & Merom \\
\hline
\end{tabular}

Bryan, TX

Arden, NC

Goldsboro, NC

Wilmington, NC

Lumberton, NC

Hartsville, SC

Lena, LA

Fannin, $\mathrm{TX}$

Brooksville, FL

Awoca, MI

Baldwin, IL

Homestead, FL

$\mathrm{P}$ arrish, FL

Indiantown, FL

Willis, $T X$

Bastrop, TX

Pekin, IL

E scatampa, MS

Konama, OK

Morrison, OK

Big Stone City, SD

Boardman, OR

Boulder, CO

wit Carmel, IN

Lavion, OK

Downtown Station, TX

Downtown Station, $T X$

Downtown Station, $T X$

Downtown Station, TX

Yerington, NV

Shreveport, LA.

Gentry, AR

Hallsville, $T X$

Midland, MI

Anderson, $T X$

Thompsons, $T X$

Rockdale, $T X$

Joseph City, AZ

Fruitland, NM

Kincaid, IL

Assury, MO

Sullivan. IN 
80) Otter Tail Power Co

81) Southmestern Eledric P ower Co

82) Ameren Energy Resouroes Generating

83) Texas Genco

Fergus Stone, MN

Shreveport, LA

St Louis, MO

Houston, TX
Big Stone

Liebeman

Duck Creek

WA.Parish
Big Stone City, SD

Mooringsport, LA

Canton, IL

Thompsons, $\mathrm{TX}$

\section{Plants with Once Ihrough w Cooling Pondisi or Canal(s) + Once Ihrough w Fresh or Salt water}

\section{Utility}

84) Arkansas Electric Coop Corp

85) Arkansas Electric Coop Corp

86) Public Service $\mathrm{Co}$ of NH

87) San Antonio Public Service Bd

88) South Carolina P ub Serv Auth

89) Springfield City of

90) Topaz Pover Group LLC
Plant

Little Rock, AR
Little Rock, AR
Berlin, CT
San Antonio, TX
Moncks Corner, SC
Springfield, MO
Austin, TX

Carl Bailey
McClellan
Merrimack
$J$ K Spruce
Dolphus M Grainger
James River Power Station
Barney M Davs

Augusta, AR

Camden, $A R$

Conoord, NH

Downtown Station, TX

Conmey, SC

Spring field, Mo

Corpus Christi, TX

\section{Plants with Recirculating Cooling w Cooling Pond(s) or Canal(s) + Recirculating w Fresh water}

\section{Utility}

91) Sierra Pacific P ower $C o$

92) South Carolina $P$ ub Serv Auth

93) Southwestern Eledric P ower Co

94) Southwestern Eledric P over Co

95) Texas Genco
Reno, NV

Moncks Corner, SC

Shreveport, LA

Shreveport, LA

Houston, TX

Plant

Tracy
Dolphus M Grainger
Wilkes
Welsh
W A.Parish

WA Parish
Sparks, NV

Conmay, SC

Avinger, $T X$

P itt sburg, $T X$

Thompsons, $T X$

\section{Plants with Recirculating Cooling with Induced Draft Cooling Tower(s)}

\begin{abstract}
Utility
96) Birchwood Power P artners LP

97) Progress E nergy Carolinas Inc

98) Oklahoma Gas \& Electric Co

99) South Mississippi EI Pw Assn
\end{abstract}

$\begin{array}{ll}\text { King George, VA } & \text { Birchwood P over } \\ \text { Raleigh, NC } & \text { Lee } \\ \text { Oklahoma City, OK } & \text { Horseshoe Lake } \\ \text { Hattiesburg, MS } & \text { R D Morrow }\end{array}$

King George, VA

Oklahoma City, OK

Hattiesburg, MS
Plant

King George, VA Goldsboro, NC Harah, OK Purvis, MIS 


\section{Plants w Once Through w Cooling Pond(s) or Canal(s) + Recirculating w induced draft cooling tower}

$\begin{array}{llll}\text { Utility } & & \text { Plant } & \\ \text { 100) Ameren E nergy Generating Co St Louis, MO } & \text { Cofteen } & \text { Coffeen, IL }\end{array}$

\section{Plants w Recirculating w Cooling Pondis or Canal(s) + Once Ihrough w Cooling Pond (s) or Canal(s)}

Utility

101) Cleco Evangeline LLC

St Landry, LA

Plant

Evangeline P ower Station St Landry, LA

Plants with Other Cooling Sustem Types or Combinations, including a Cooling Pond

\begin{tabular}{|c|c|c|c|c|}
\hline & Utility & & Plant & \\
\hline 102) & Progress Energy Carolinas Inc & Raleigh, NC & Roxboro & Semora, NC \\
\hline 103) & Lansing City of & Lansing, MI & Eckert Station & Lansing, MI \\
\hline 104) & E ntergy Mississippi Inc & The Woodlands, TX & Delta & Cleveland, MS \\
\hline 105) & Platte River Power Authority & Fort Collins, $\mathrm{CO}$ & Rawhide & Wellington, $\mathrm{CO}$ \\
\hline 106) & Vienna Operations Inc & Vienna, MD & Venna Operations & Venna, MD \\
\hline 107) & TXU Eledric Co & Dallas, $T X$ & SandowNo 4 & Rockdale, TX \\
\hline 108) & Wisconsin Power \& Light $\mathrm{Co}$ & Madison, WI & Columbia & Pardeeville, WI \\
\hline 109) & International $\mathrm{Paper} \mathrm{Co}$ & Mansfield, LA & Mansfield Mill & Mansfield, LA \\
\hline 110) & Reliant Energy Etimanda Inc & Houston, TX & $\begin{array}{c}\text { Etiwanda Generating } \\
\text { Station }\end{array}$ & $\begin{array}{c}\text { Rancho Cucam onga, } \\
\text { CA }\end{array}$ \\
\hline 111) & Reliant Energy NE Mgt Co & Houston, TX & Keystone & Shelocta, PA \\
\hline
\end{tabular}

Source: USDOE/EIA, Form EIA-767: Annual Steam-Electric Plant Operation and Design Data. 2005 data. http://www.eia.doe.gov/cneaf/electricity/page/eia767.html 
Chapter 3 - Science and History of Wetlands 
Chapter 4 - Opportunities and Challenges Associated with Using Wetlands for Power Plant Water Storage and / or Cooling

Figure C. Impact of cooling water on power generation efficiency. Chart indicates efficiency loss versus cooling water temperature in various power generation cycles.

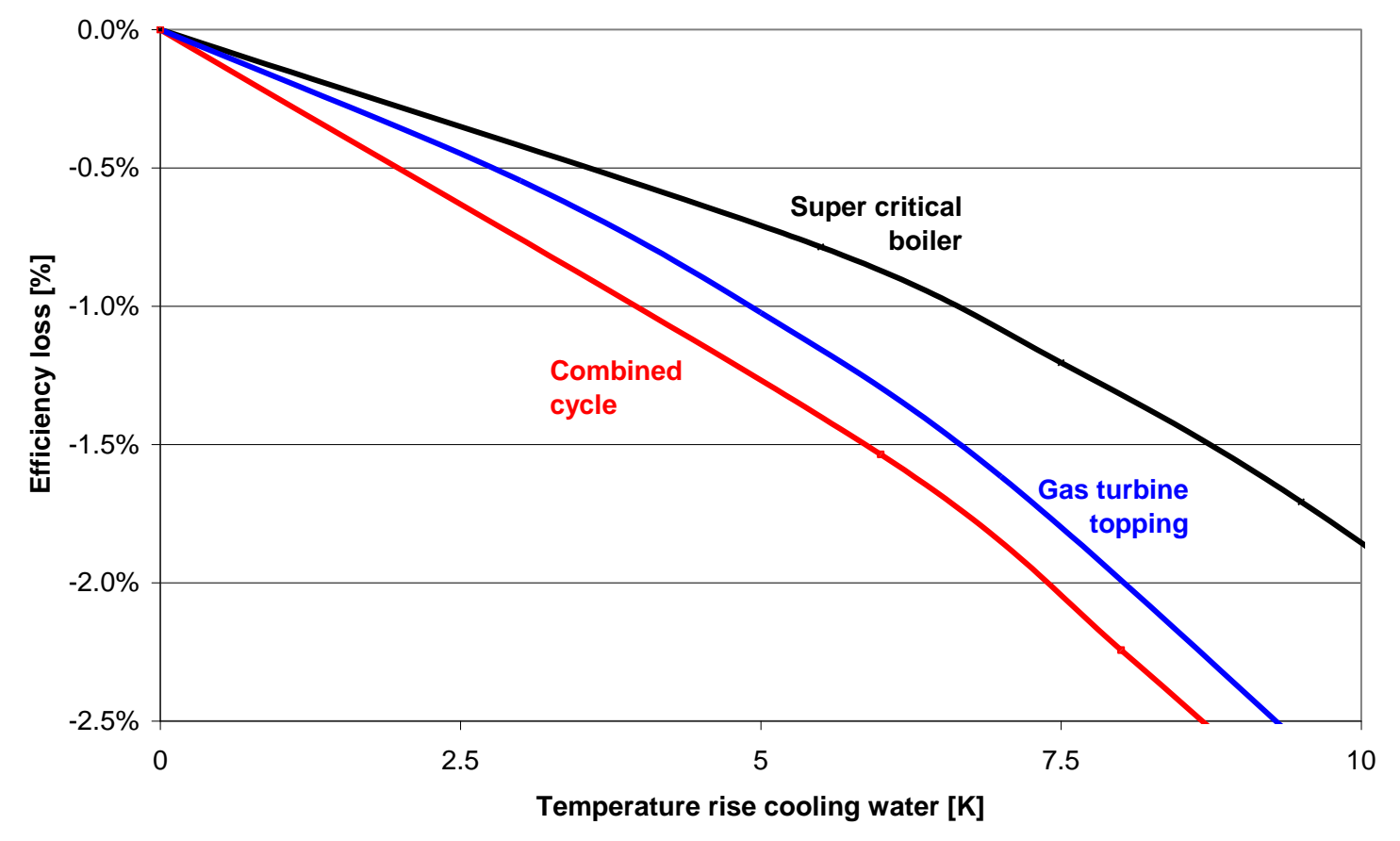

Source: KEMA, 2005. 


\section{Table C - Part 1. Power Plant Water Use Classification and the Potential Role of Constructed Wetlands.}

\begin{tabular}{|c|c|c|c|}
\hline $\begin{array}{l}\text { Existing Power Plant } \\
\text { Water Use(s) }\end{array}$ & $\begin{array}{l}\text { Potential Wetland } \\
\text { Functional Role for } \\
\text { Power Company }\end{array}$ & $\begin{array}{l}\text { Potenfial Stressors to } \\
\text { ecology of Whetlands }\end{array}$ & $\begin{array}{l}\text { PotercialOperational } \\
\text { Benefits to power company }\end{array}$ \\
\hline $\begin{array}{l}\text { 1) Once through use of } \\
\text { water } \\
\text { - Large volume of } \\
\text { wrater } \\
\text { - Heated wrater put } \\
\text { back } \\
\text { - No evaporative } \\
\text { losses }\end{array}$ & $\begin{array}{l}\text { Use wetland as } \\
\text { teservoir of water } \\
\text { storage source } \\
\text { Use wretland as thetmal } \\
\text { sink to co ol water } \\
\text { before dischange to } \\
\text { tiver, thus providing } \\
\text { ecological benef its }\end{array}$ & $\begin{array}{l}\text { - Heated water going } \\
\text { into existing } \\
\text { teceiving waters } \\
\text { - Fish kills } \\
\text { - Instre am flow } \\
\text { impact } \\
\text { - Low DO/othex } \\
\text { gases } \\
\text { - Zones of bio- } \\
\text { impairme nt created }\end{array}$ & $\begin{array}{l}\text { - Reduces contaminants to } \\
\text { allow multiple cycles (e.g. } \\
\text { when dischatge is limited by } \\
\text { heawy metals being at } \\
\text { dischatoge limit) } \\
\text { - Contributes to teduced } \\
\text { primary s outce wattet needs } \\
\text { during summer/drought } \\
\text { periods }\end{array}$ \\
\hline $\begin{array}{l}\text { 2) Once through with } \\
\text { effluent put into } \\
\text { ecological are a in } \\
\text { recharge co astal or other } \\
\text { netlands }\end{array}$ & $\begin{array}{l}\text { Use wretland as powrex } \\
\text { plant buffer }\end{array}$ & $\begin{array}{l}\text { - Create a bio- } \\
\text { gxadient associated } \\
\text { uxith he at loss } \\
\text { - Occasional } \\
\text { gradient shifts, } \\
\text { temporary } \\
\text { impairment of } \\
\text { uxetland oxganisms }\end{array}$ & $\begin{array}{l}\text { - Remo ves ditect impact to } \\
\text { natural teceiving } \\
\text { wraterbodies } \\
\text { - May allow for incre ased } \\
\text { draur from teceiving waters } \\
\text { if no detection limits or } \\
\text { exceedances tesult. } \\
\text { - May contribute (or test ore } \\
\text { hist oric) water source for } \\
\text { existing deteriorated } \\
\text { ecological systems }\end{array}$ \\
\hline $\begin{array}{l}\text { 3)Reprocessing/Cle aning } \\
\text { cooling to wer, boiler and } \\
\text { process blow down water. }\end{array}$ & $\begin{array}{l}\text { Polishing of watex } \\
\text { quality } \\
\text { Incte ase thermal he at } \\
\text { exchanger efficiency of } \\
\text { boilets }\end{array}$ & $\begin{array}{l}\text { - Chemical } \\
\text { constituents } \\
\text { (carbonates, } \\
\text { Calcium, } \\
\text { magnesium and } \\
\text { other scale agents) } \\
\text { Heat (boilex } \\
\text { blowrdourn) }\end{array}$ & $\begin{array}{l}\text { - Remo ves scale and othex } \\
\text { constituents to allowr wrater } \\
\text { teuse, perhaps in cooling } \\
\text { process, saving } \sim 4 \% \text { of } \\
\text { antrual water needs from } \\
\text { tawr water source. } \\
\text { - Saves wrate wrater treatment, } \\
\text { teducing plant intemal ox } \\
\text { external oper ational cost }\end{array}$ \\
\hline
\end{tabular}




\section{Table C - Part 2. Power Plant Water Use Classification and the Potential Role of Cooling Wetlands.}

\begin{tabular}{|c|c|c|c|}
\hline $\begin{array}{l}\text { Existing Power Plant } \\
\text { Water U se(s) }\end{array}$ & $\begin{array}{l}\text { Potential wetland } \\
\text { Functional Role for } \\
\text { Power Company }\end{array}$ & $\begin{array}{l}\text { Potential Stressors to } \\
\text { ecology of Whetlands }\end{array}$ & $\begin{array}{l}\text { Potenfialoperational } \\
\text { Benefits to power comp any }\end{array}$ \\
\hline 4) Cooling pond runoff & $\begin{array}{l}\text { Link waste water pond } \\
\text { to pretteatment cells } \\
\text { and then to restoxed } \\
\text { unetland to offer } \\
\text { polishing and te-use } \\
\text { potentials }\end{array}$ & $\begin{array}{l}\text { - Possible } \\
\text { contaminants } \\
\text { from cooling pond } \\
\text { tunoff } \\
\text { - Wetup and dry } \\
\text { doum cycles } \\
\text { difficult for most } \\
\text { ecologic al systems }\end{array}$ & $\begin{array}{l}\text { - Beneficially te-uses waste } \\
\text { wrater for cooling, and in the } \\
\text { future for slutry water needs } \\
\text { - Reduces wrater needs from } \\
\text { native source wraters }\end{array}$ \\
\hline $\begin{array}{l}\text { 5) Bottom ash transport } \\
\text { water (slumy) to ash pond }\end{array}$ & $\begin{array}{l}\text { Lituk wraste water } \\
\text { stre am from ash pond } \\
\text { to pretreatment cells } \\
\text { and then to testoted } \\
\text { wretland to offer } \\
\text { polishing and te-use } \\
\text { potentials }\end{array}$ & $\begin{array}{l}\text { Possible } \\
\text { contaminants from } \\
\text { bottom ash slurry } \\
\text { Wetup and dry } \\
\text { dowrn cycles } \\
\text { difficult for most } \\
\text { ecologic al systems }\end{array}$ & $\begin{array}{l}\text { - Beneficially te-uses waste } \\
\text { water for cooling, and in the } \\
\text { future for slurry water needs } \\
\text { - Reduces water needs from } \\
\text { na ative soutce wraters }\end{array}$ \\
\hline $\begin{array}{l}\text { 6) Pyries transport water } \\
\text { slury and whburned co al } \\
\text { dust to ash pond }\end{array}$ & $\begin{array}{l}\text { Lithk wraste slutry to } \\
\text { pretreatment cells and } \\
\text { then to testoved } \\
\text { wretland to offer } \\
\text { polishing and te-use } \\
\text { potentials }\end{array}$ & $\begin{array}{l}\text { - Possible } \\
\text { contaminatus from } \\
\text { waste slutry } \\
\text { - Wet up and dry } \\
\text { down cycles } \\
\text { difficult for most } \\
\text { ecologic al systems }\end{array}$ & $\begin{array}{l}\text { - Beneficially te-uses waste } \\
\text { wrater for cooling, and in the } \\
\text { future for slurry water needs } \\
\text { - Reduces water needs from } \\
\text { native soutce wraters }\end{array}$ \\
\hline $\begin{array}{l}\text { 7) Limes tone pile water } \\
\text { slury }\end{array}$ & $\begin{array}{l}\text { Link waste slurry pond } \\
\text { to pretreatment cells } \\
\text { and then to testoved } \\
\text { unetland to offer } \\
\text { polishing and te-use } \\
\text { potentials }\end{array}$ & $\begin{array}{l}\text { Possible } \\
\text { contaminants from } \\
\text { limstone slutry } \\
\text { Wetup and dry } \\
\text { doumn cycles } \\
\text { difficult for most } \\
\text { ecologic al systems }\end{array}$ & $\begin{array}{l}\text { - Beneficially te-uses waste } \\
\text { wrater for cooling, and in the } \\
\text { future for slutry water needs } \\
\text { - Reduces wrater needs from } \\
\text { native soutce wraters }\end{array}$ \\
\hline
\end{tabular}


Table D. Summary of Upper Thermal Tolerance of Various Freshwater Biota

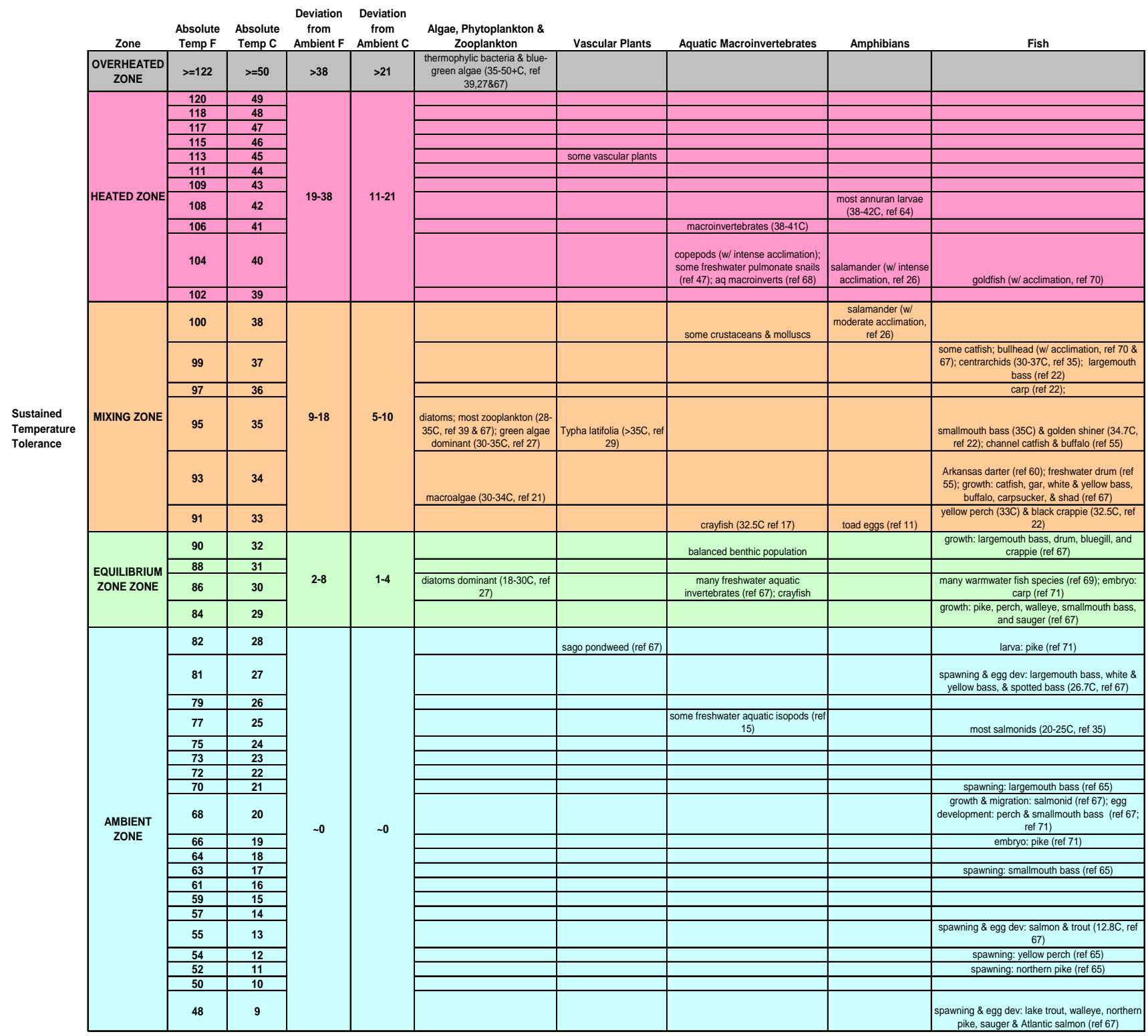

Table focuses on warm water and cool water species of Upper Midwest.

Temperature thresholds represent adult tolerance unless otherwise noted. Many life forms require periods of somewhat cooler water to reproduce and grow.

Table assimilates maximum temperature, upper tolerance, upper critical temperature, lethal limit, upper incipient lethal temperature, upper $\mathrm{LT}_{50}$, and $\mathrm{CT}_{\text {Maxx }}$. 
Chapter 5 - Wetlands Water Cooling - Evaluation Model 
Chapter 6 - Wetland Water Cooling Demonstration Project

RACETRACK WETLAND MONITORING RESULTS AND STATISTICAL ANALYSIS

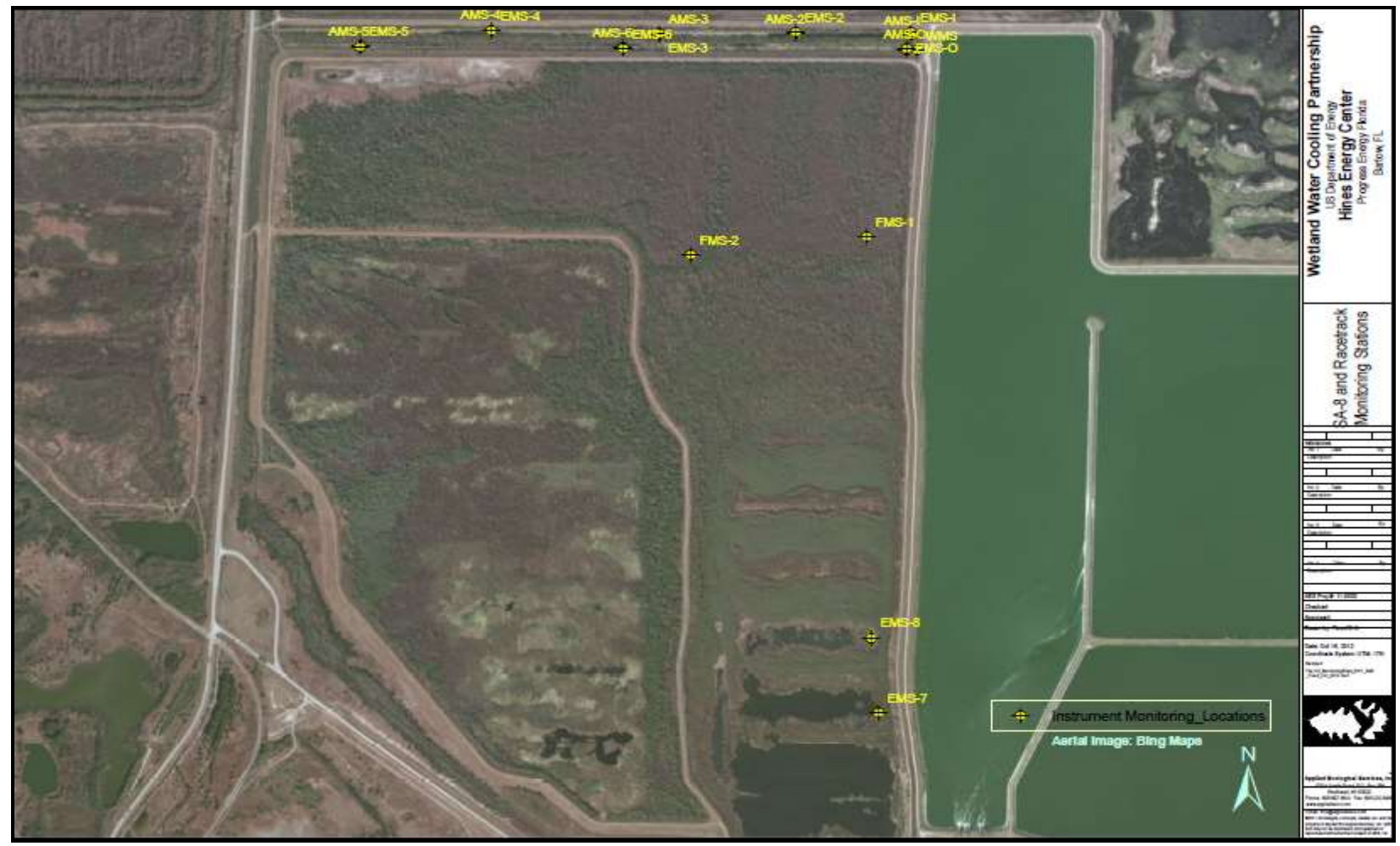

Map 1. Monitoring Station Locations - Racetrack and SA-8 wetlands Hines Energy Complex, Bartow, Florida 
Figure 1. Daily averages of every 15 minutes of air temperature and water temperature at (a) the surface, (b) aquatic, and (c) bottom of the stations in the wetland ... in 2012

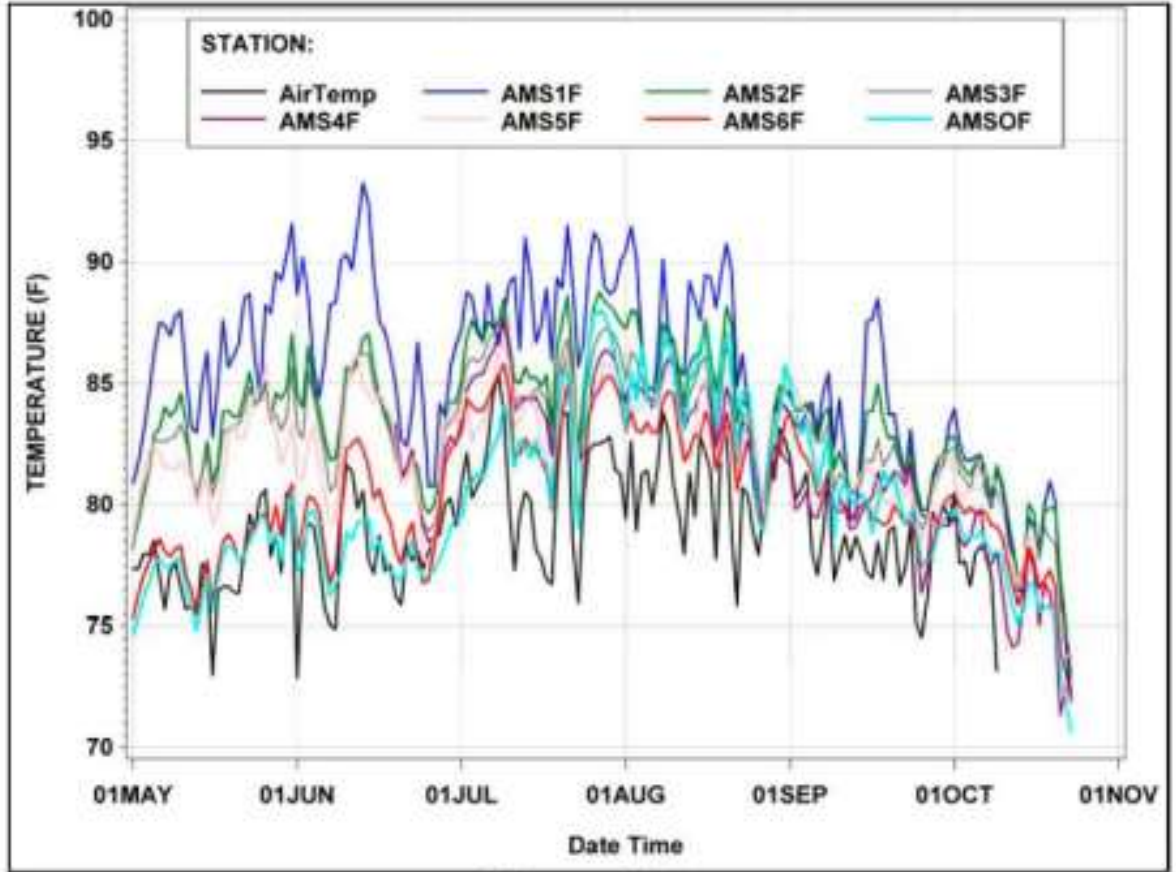

Figure 1 (a)

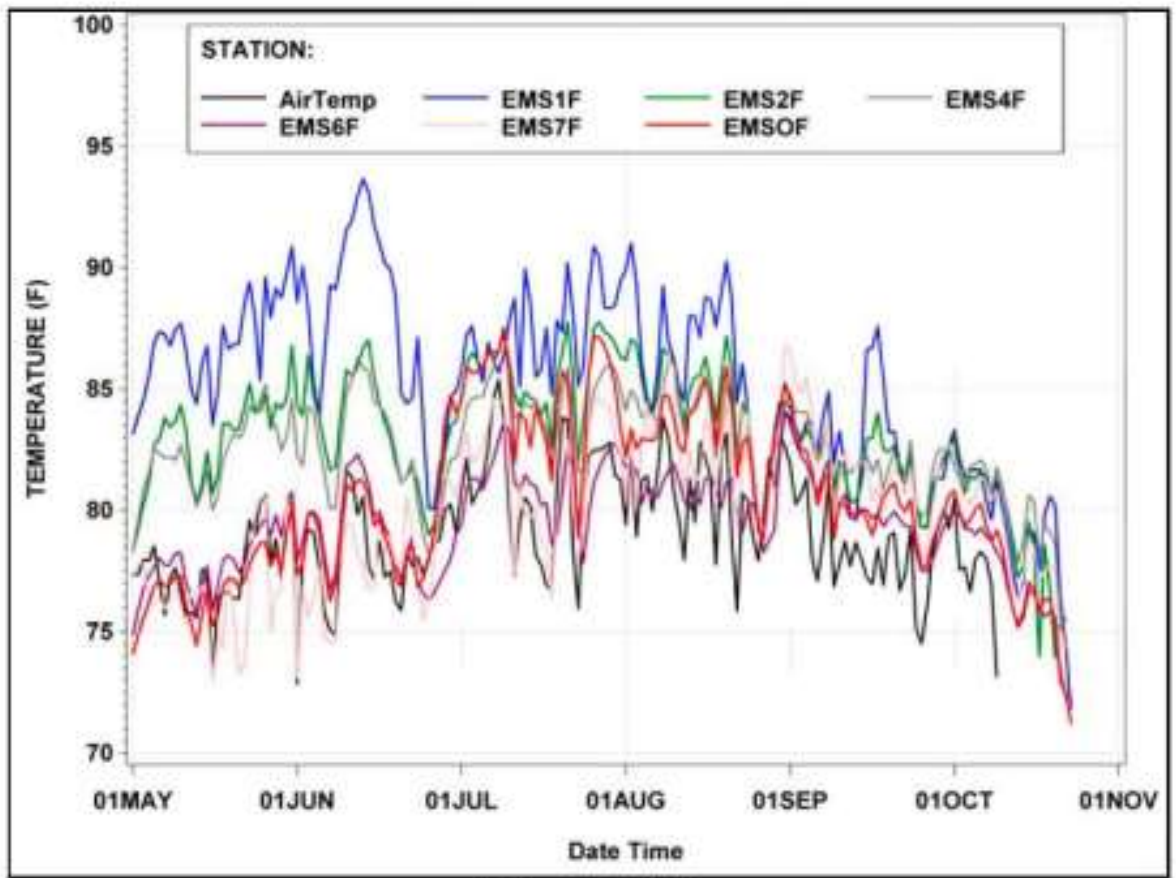

Figure 1 (b) 


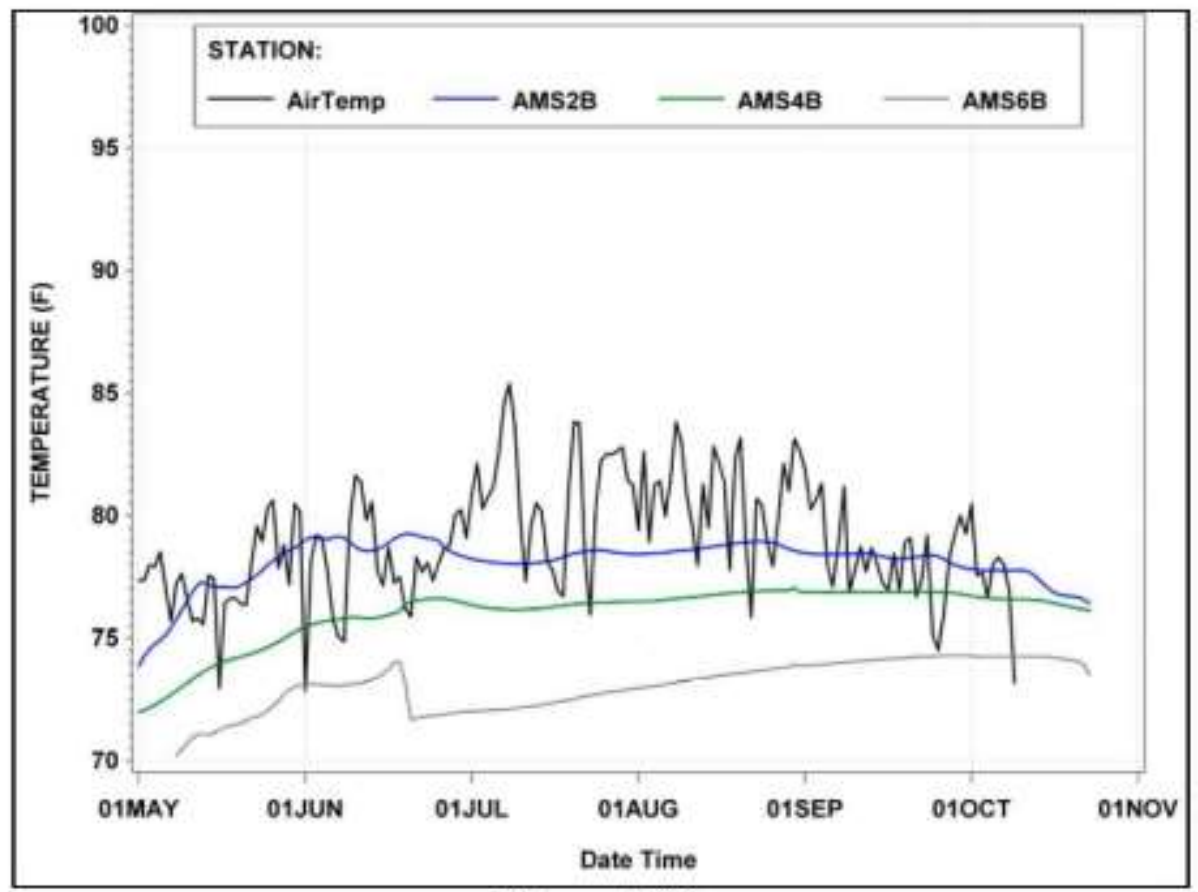

Figure 1 (c)

Figure 2. Daily averages of every 15 minutes of water flows and surface water temperature at inlet and outlet

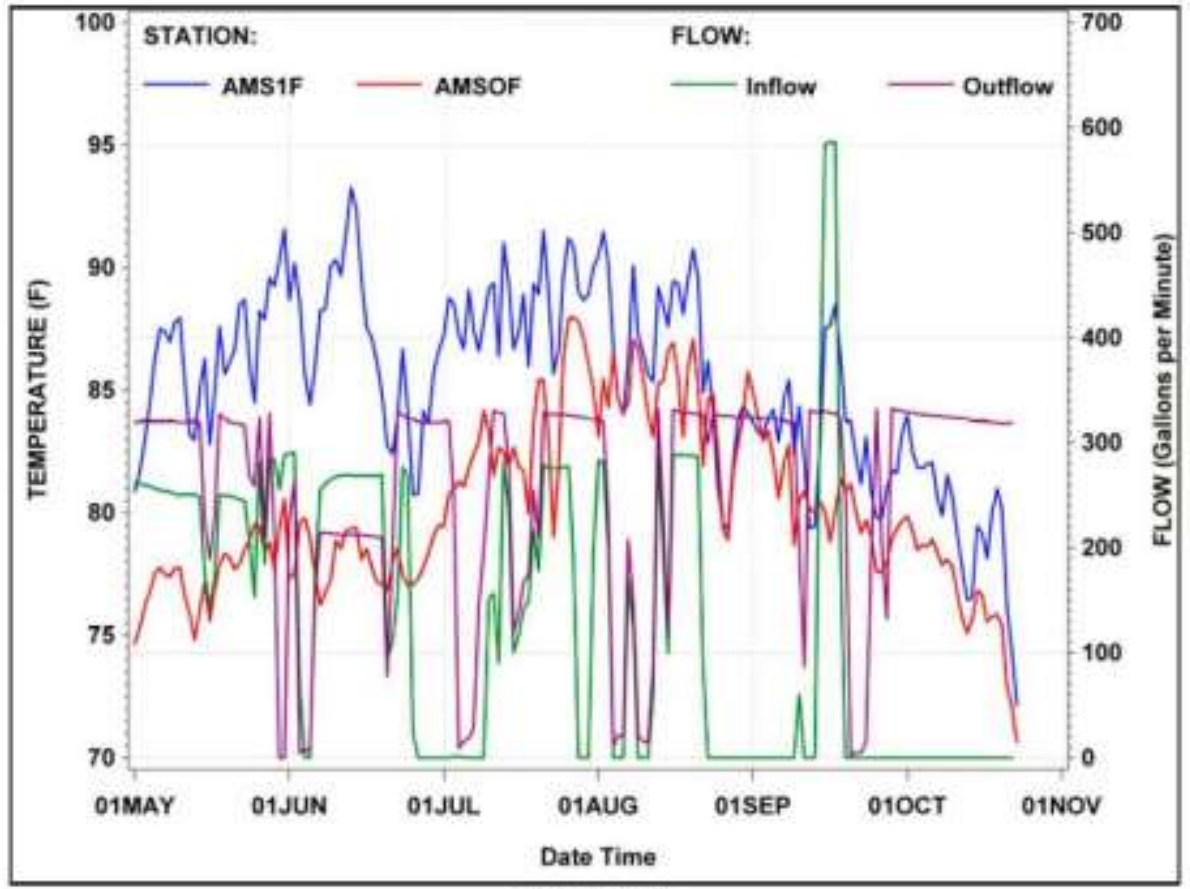

Figure 2 
Figure 3. Daily averages of every 15 minutes of water temperature (a) in water 3 inch above the sediments, (b) 3 inches and (c) 12 inches in the sediments

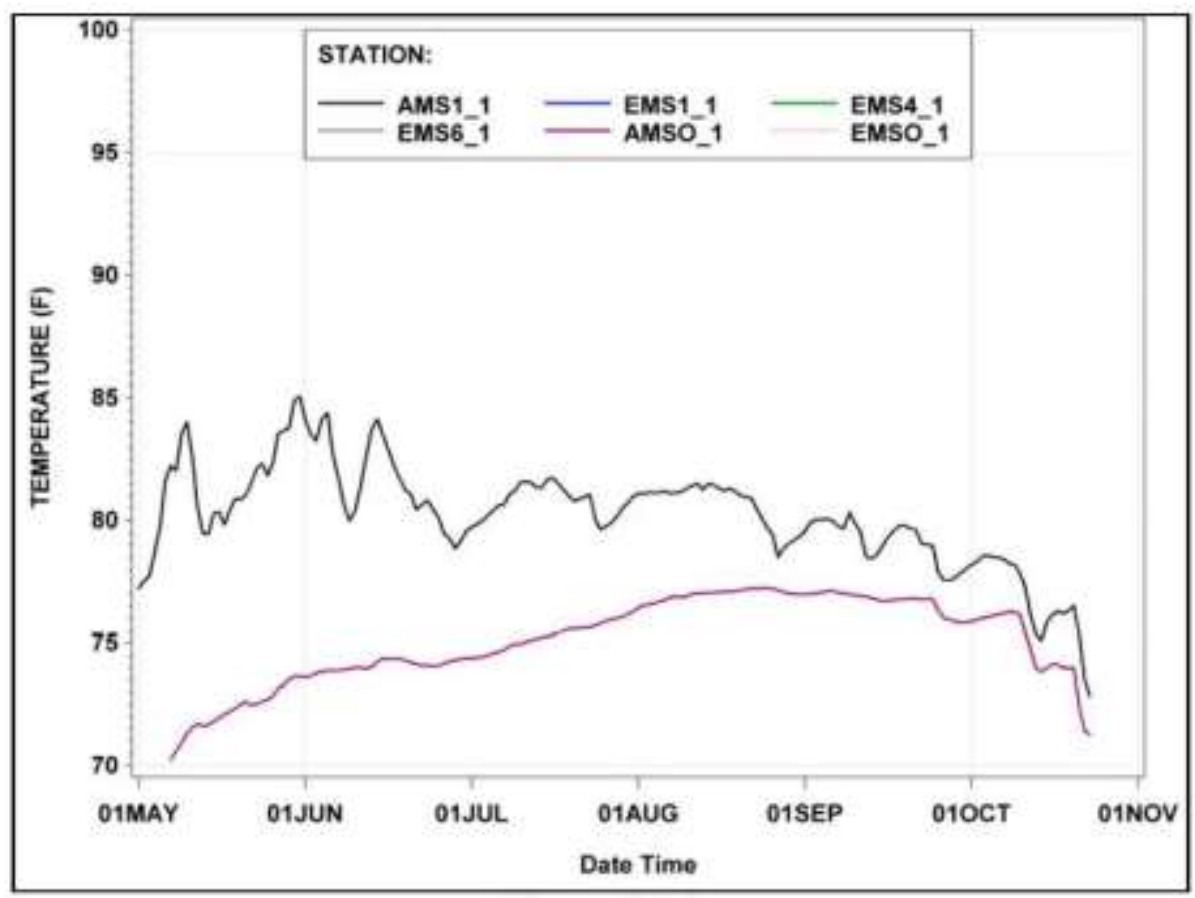

Figure 3 (a)

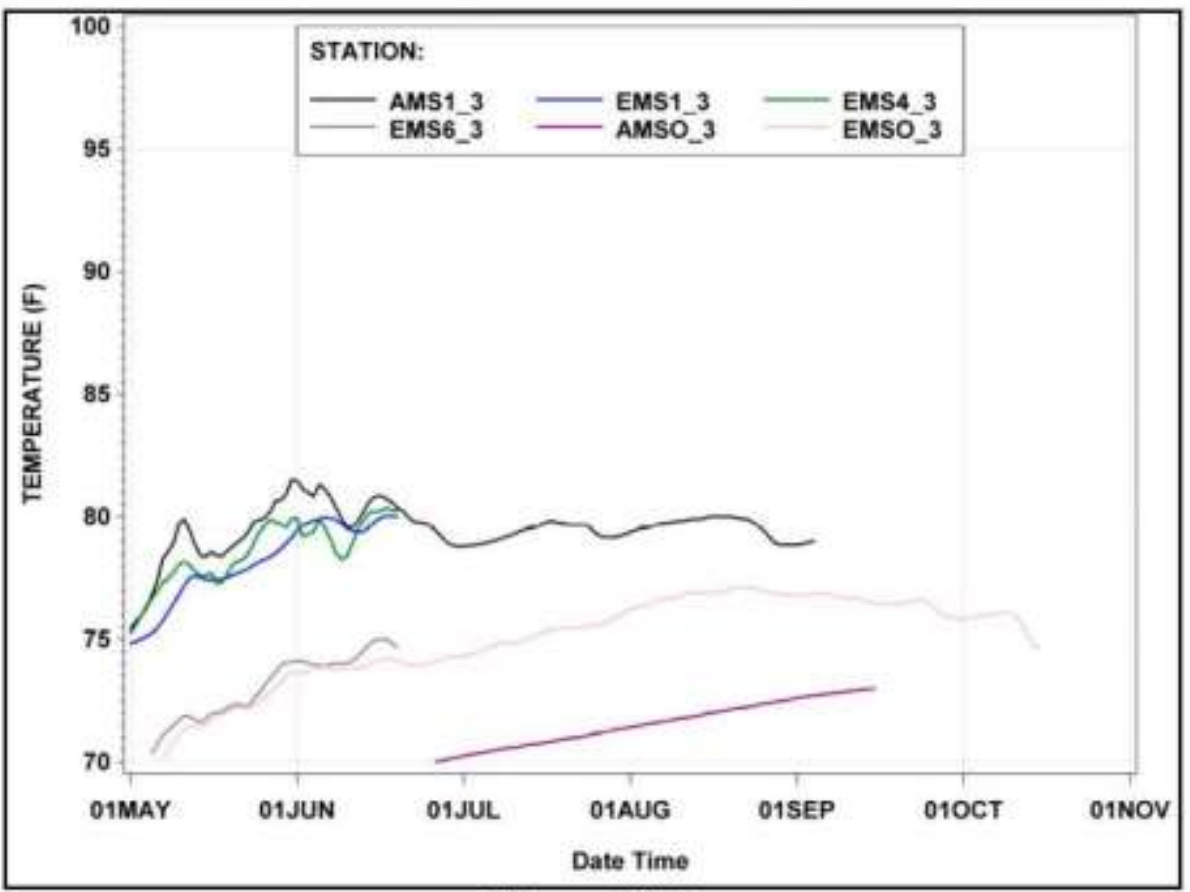

Figure 3 (b) 


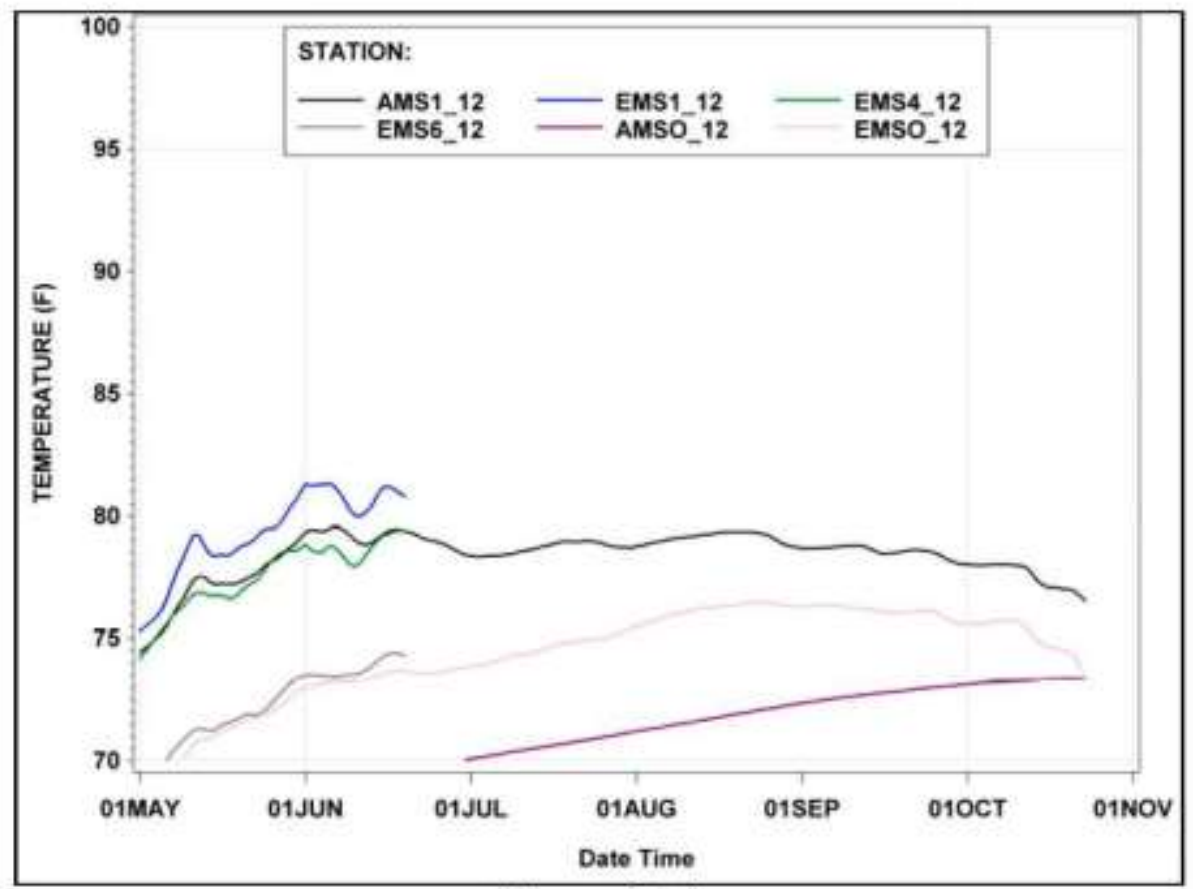

Figure 3 (c)

Figure 4. Descriptive statistics of surface water temperature as pump is (a) on, (b) off, and (c) on/off.

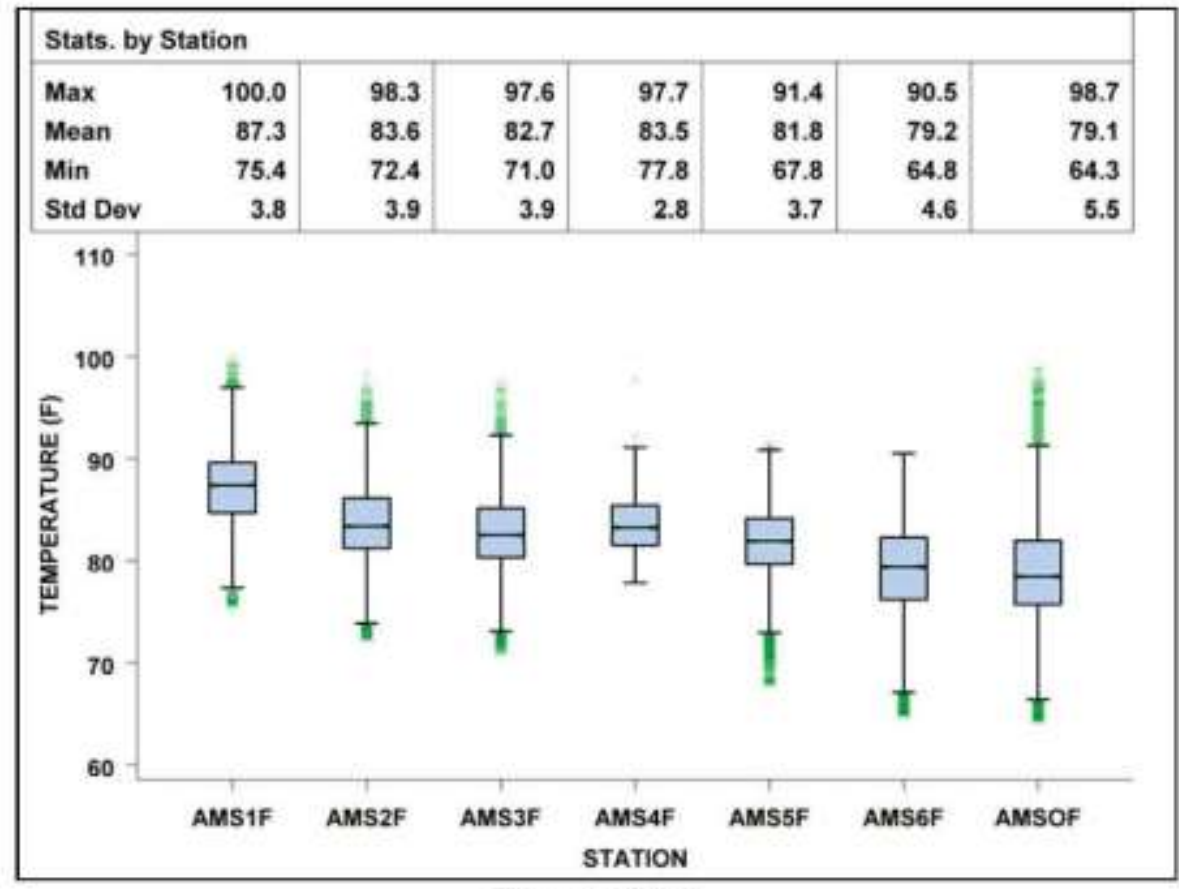

Figure 4 (a) 


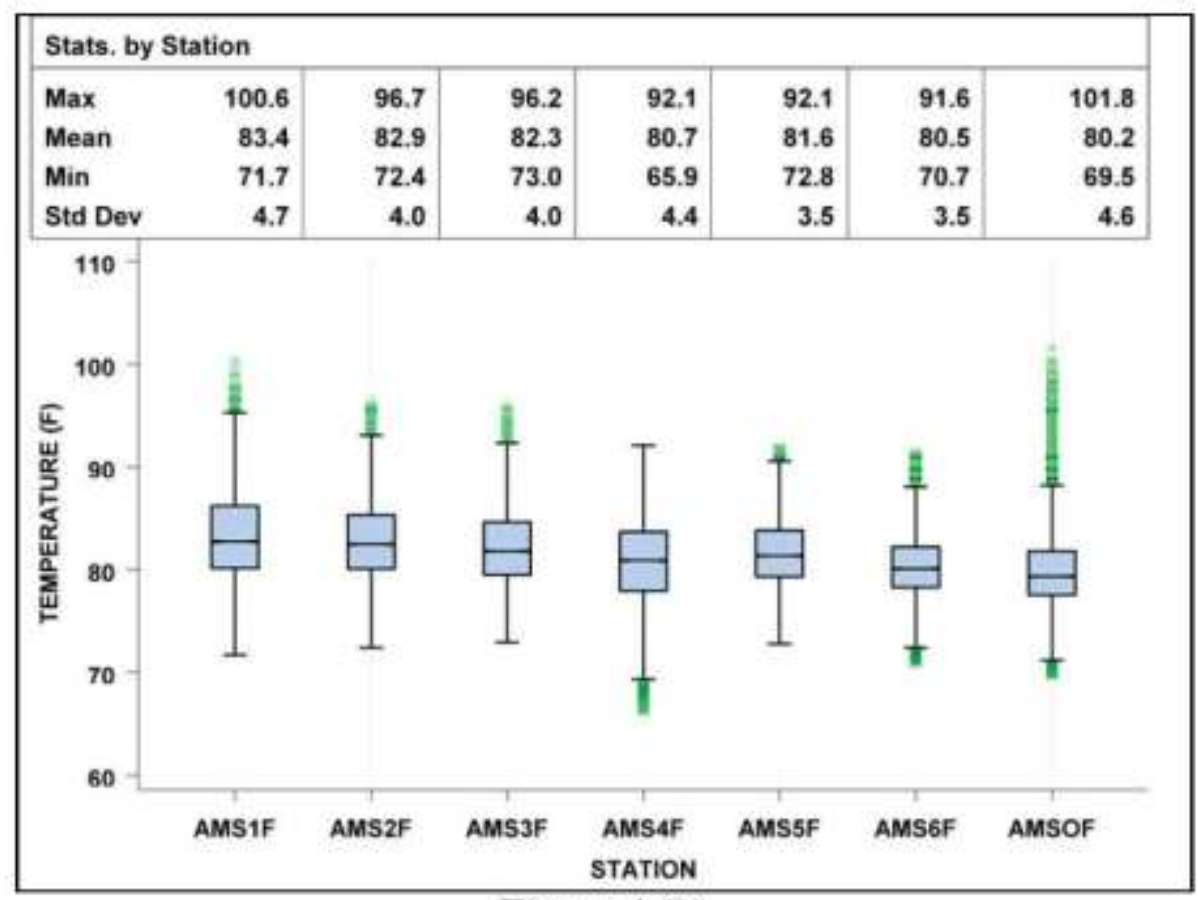

Figure 4 (b)

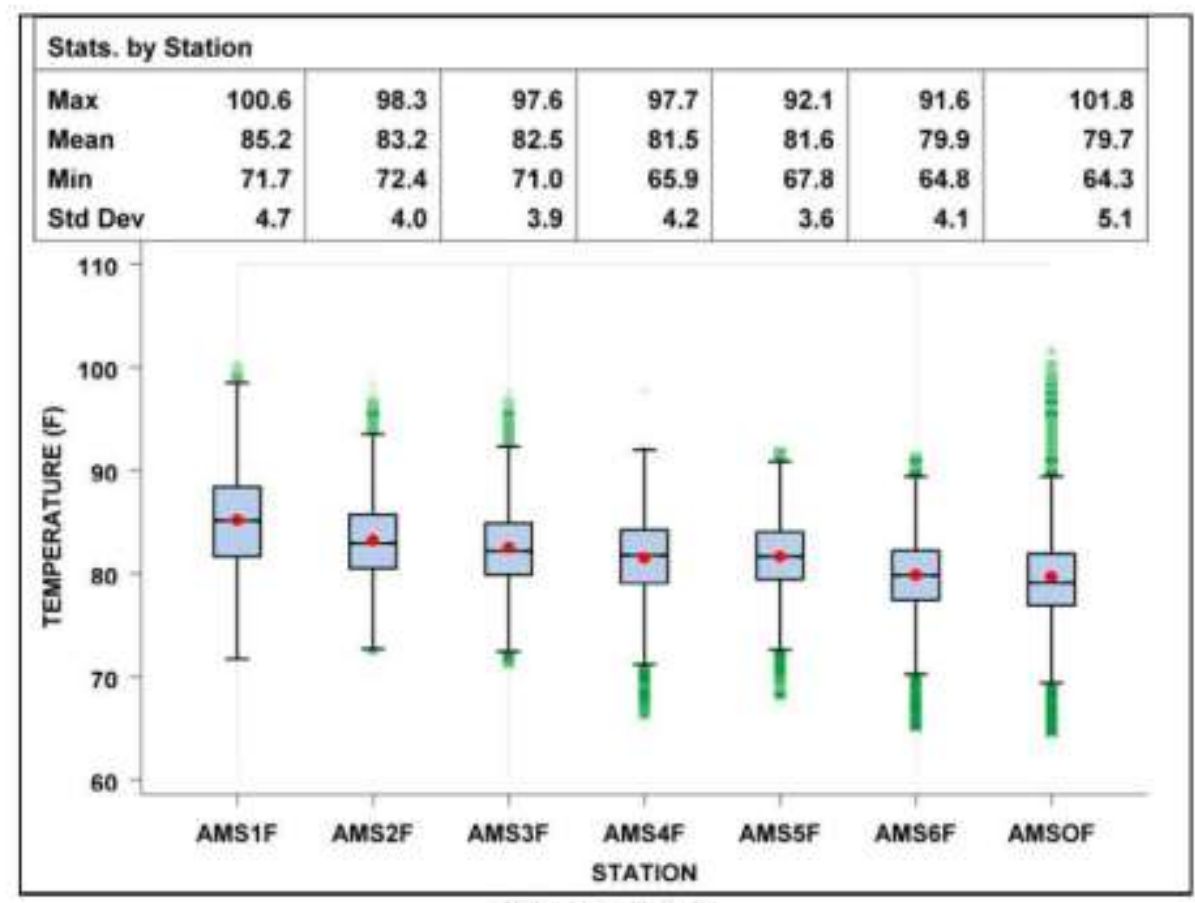

Figure 4 (c) 
Figure 5. Descriptive statistics of EMSF as pump is (a) on, (b) off, and (c) on/off.

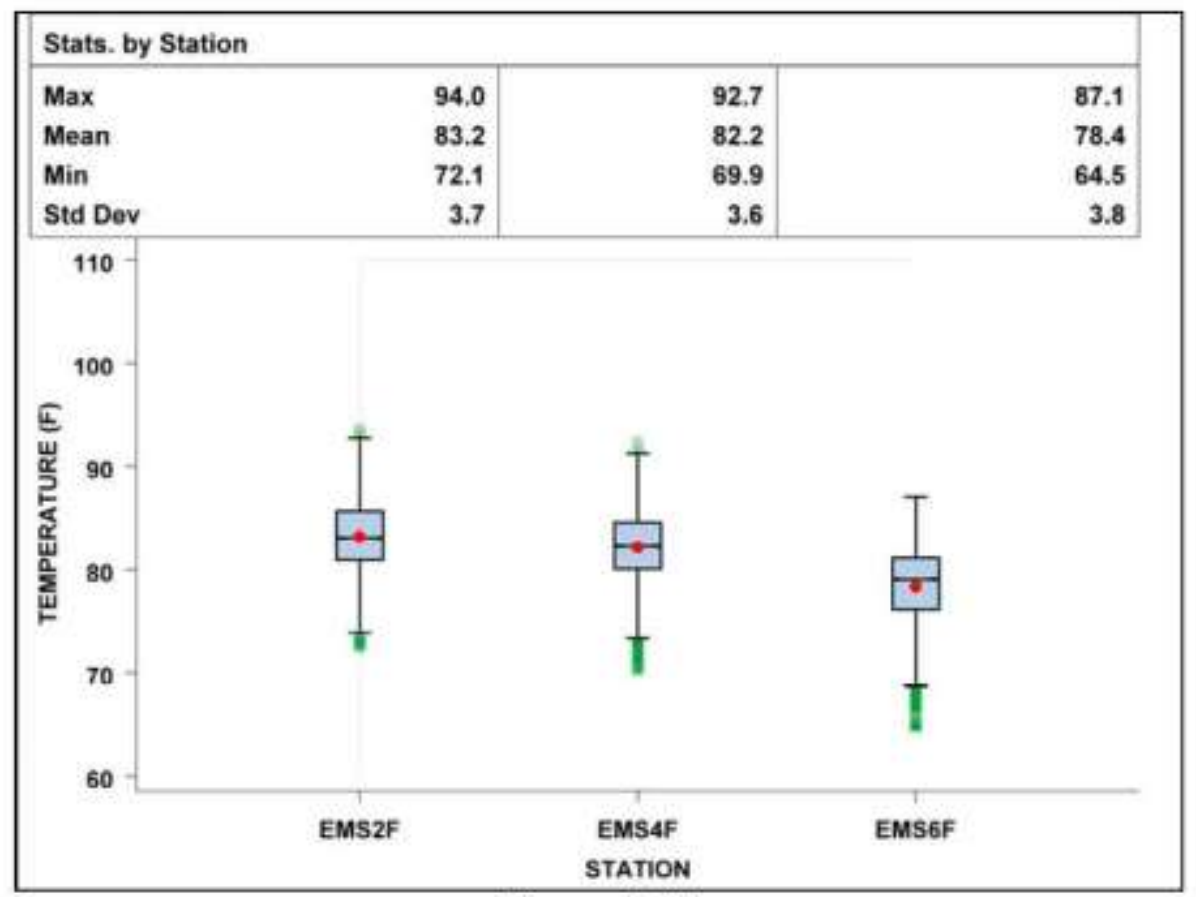

Figure 5 (a)

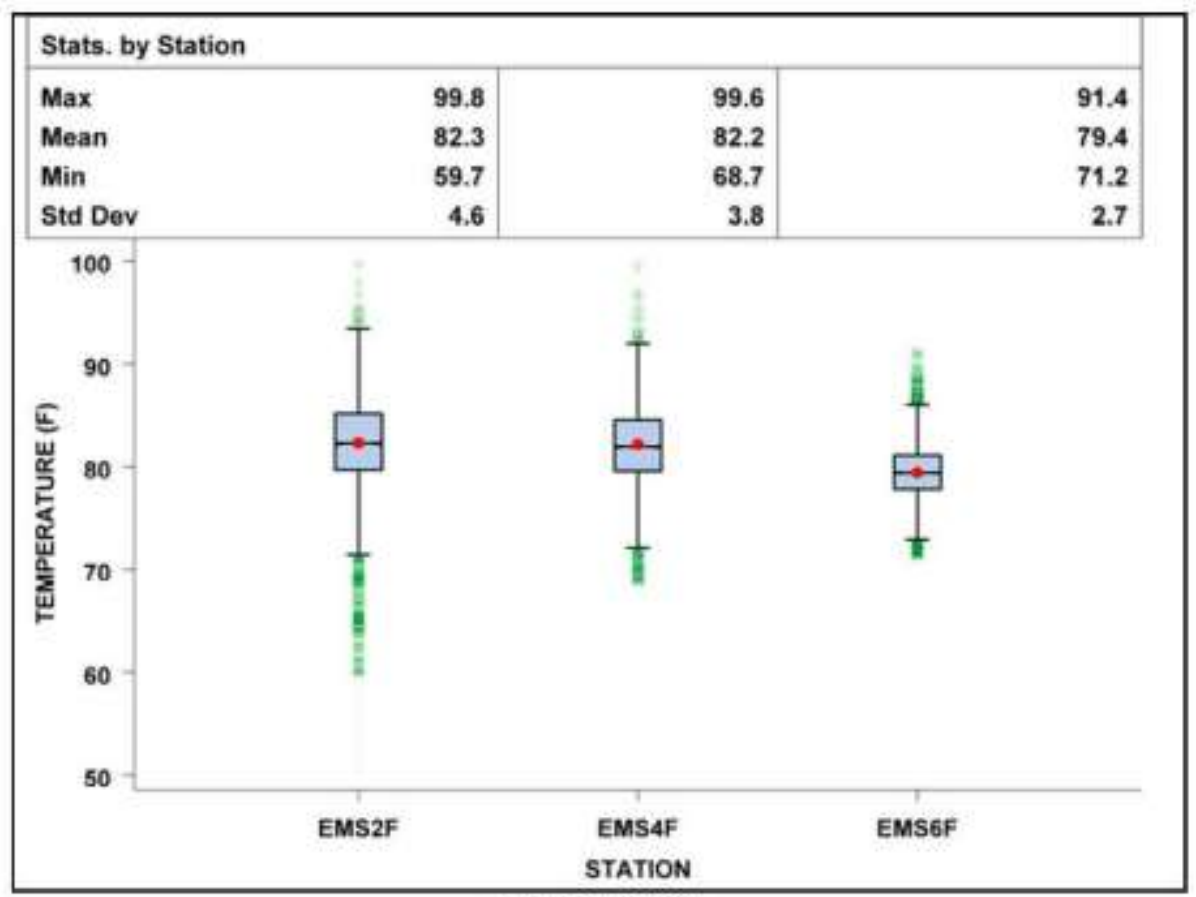

Figure 5 (b) 


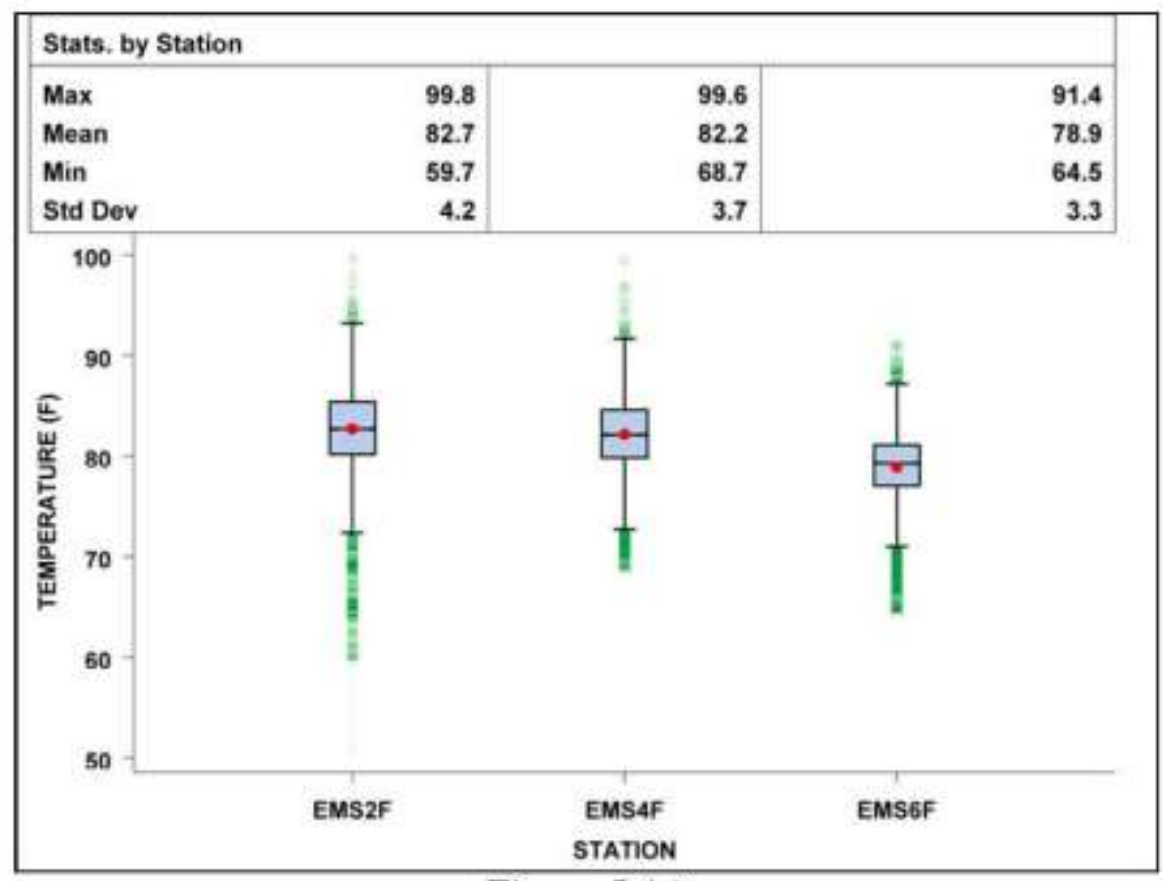

Figure 5 (c)

Figure 6. Descriptive statistics of water temperature in water 3 inch above the sediments as pump is (a) on, (b) off, and (c) on/off.

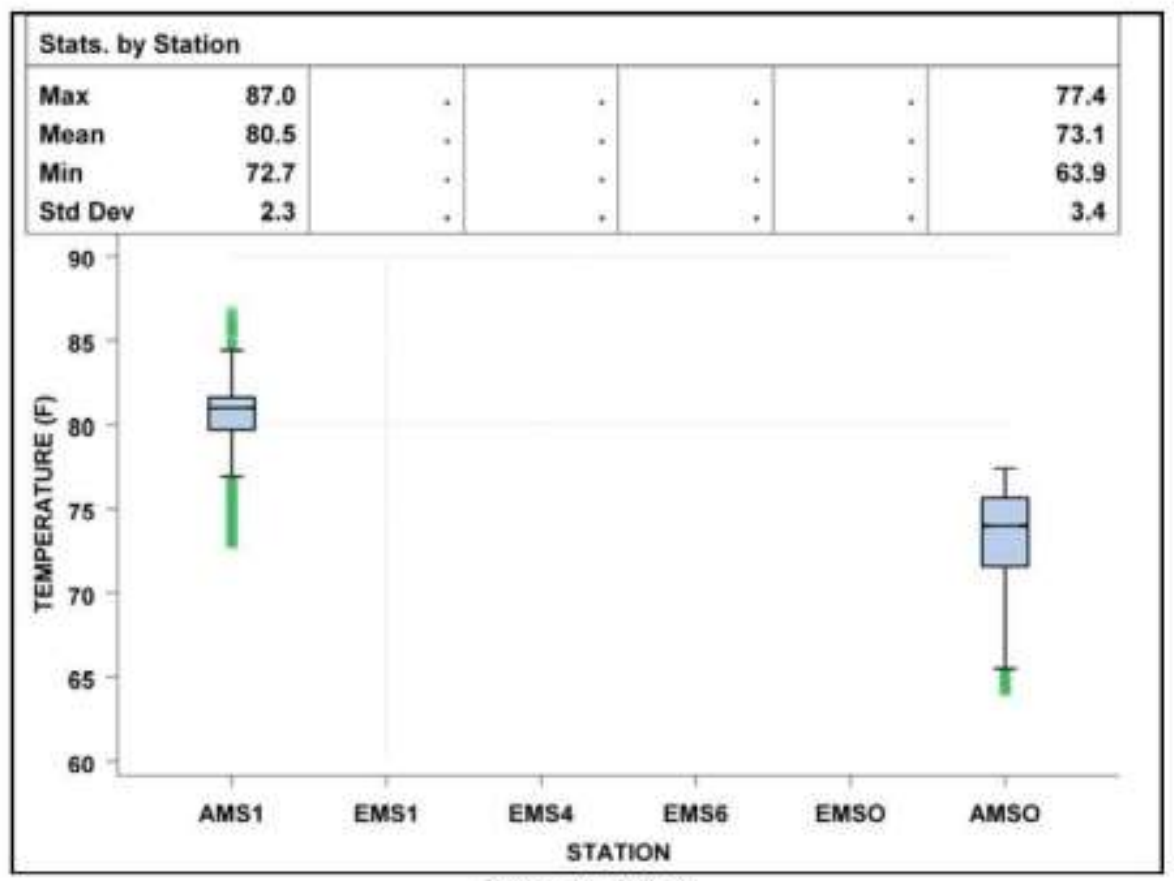

Figure 6 (a) 


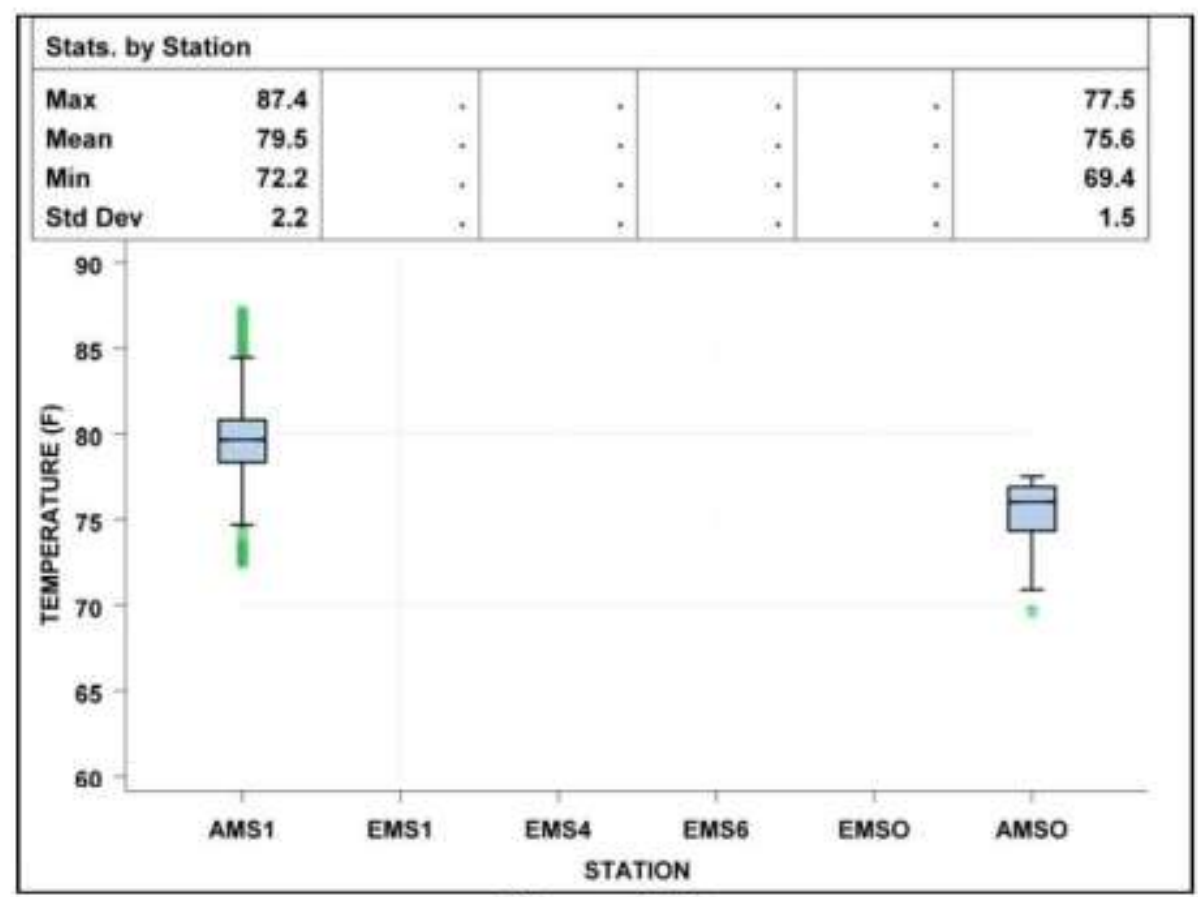

Figure 6 (b)

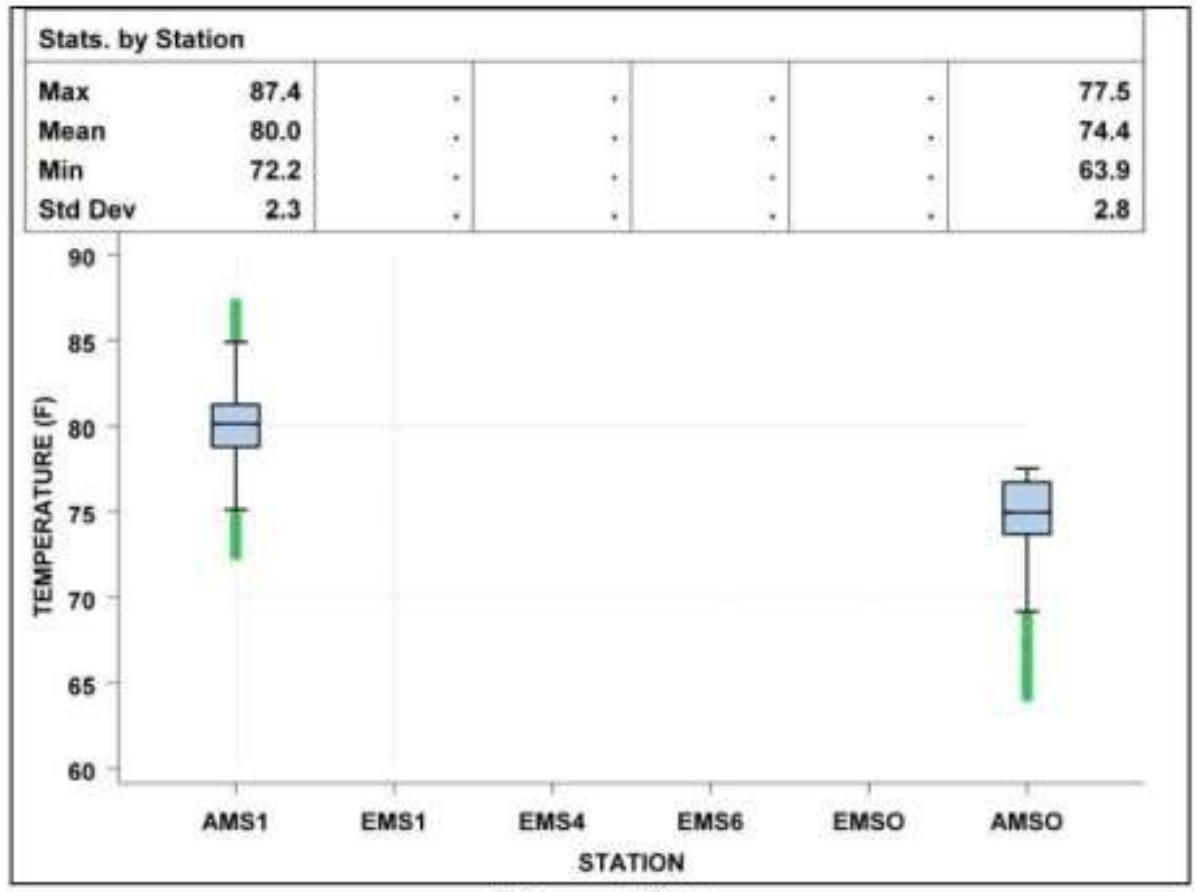

Figure 6 (c) 
Figure 7. Descriptive statistics of water temperature in water 3 inch in the sediments as pump is (a) on, (b) off, and (c) on/off.

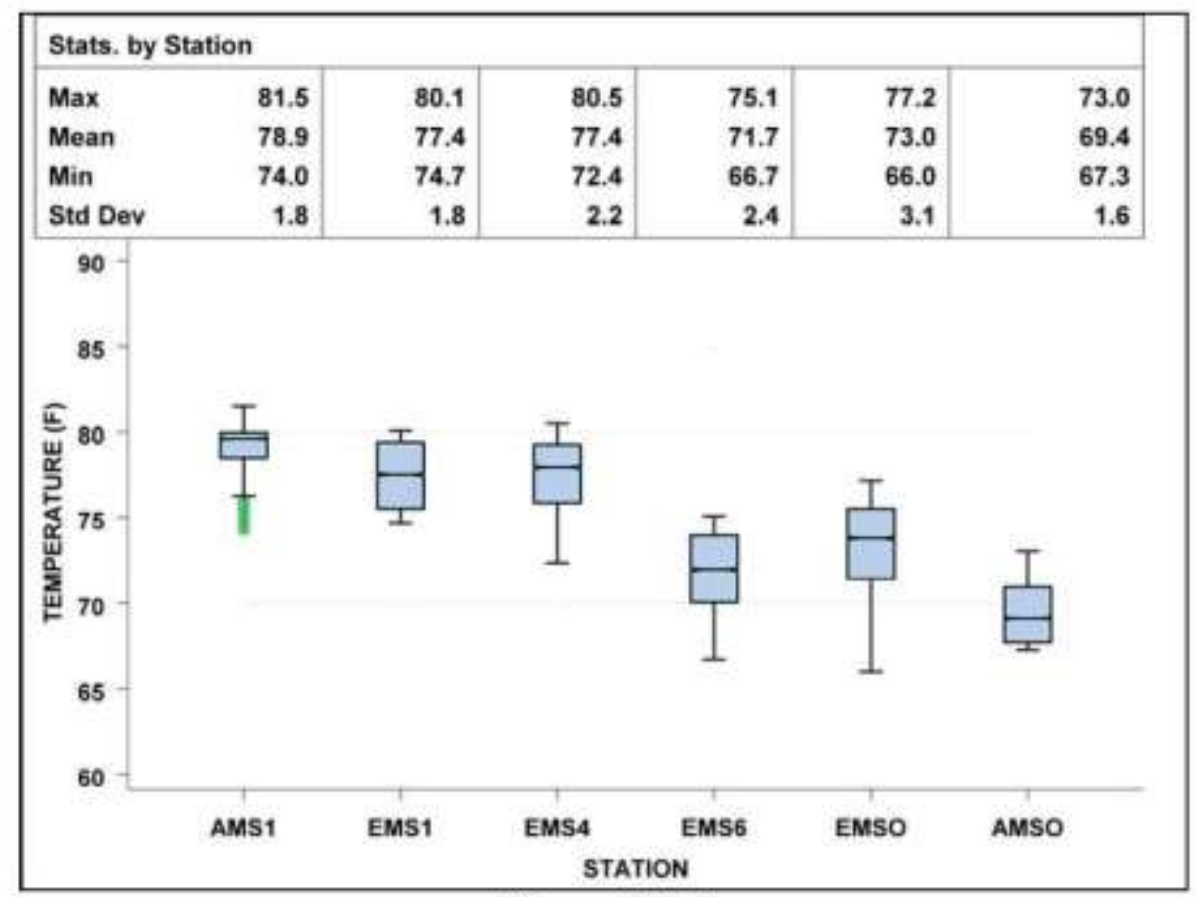

Figure 7 (a)

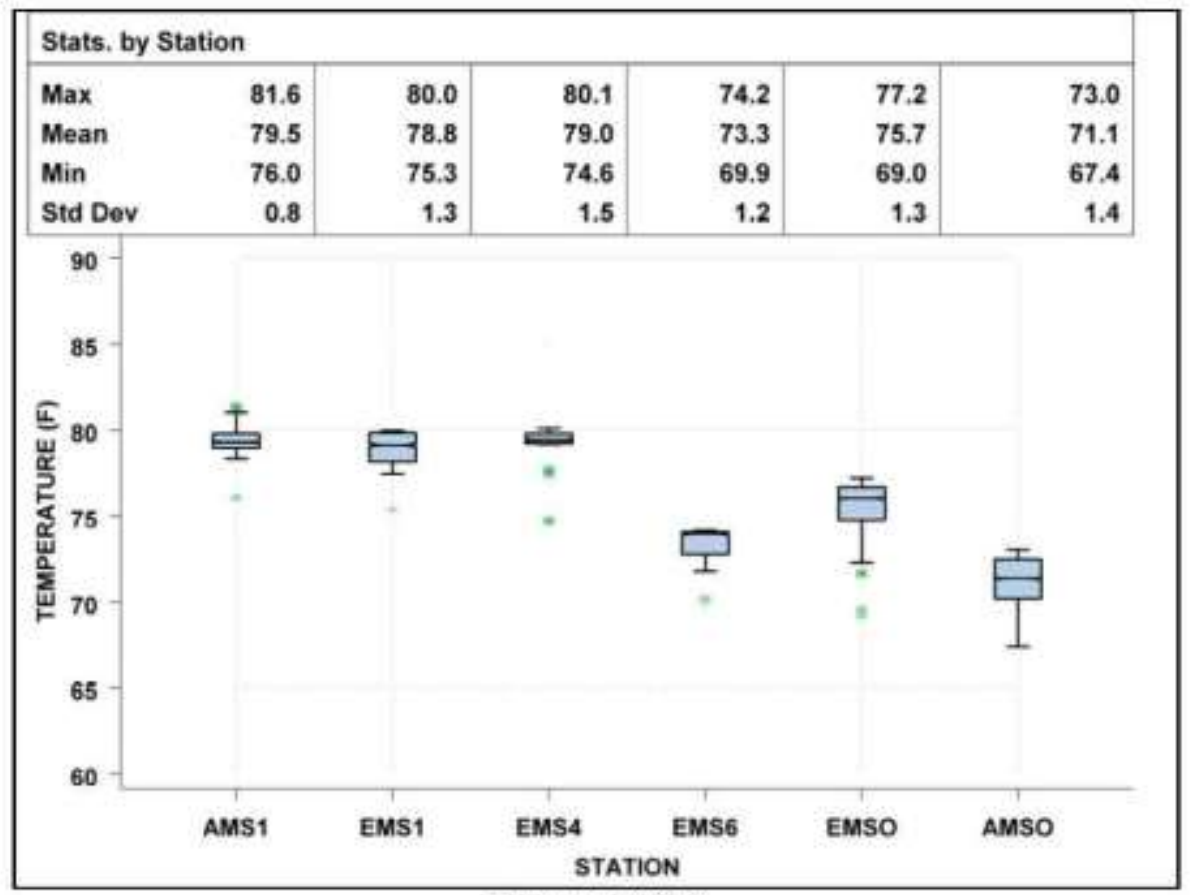

Figure 7 (b) 


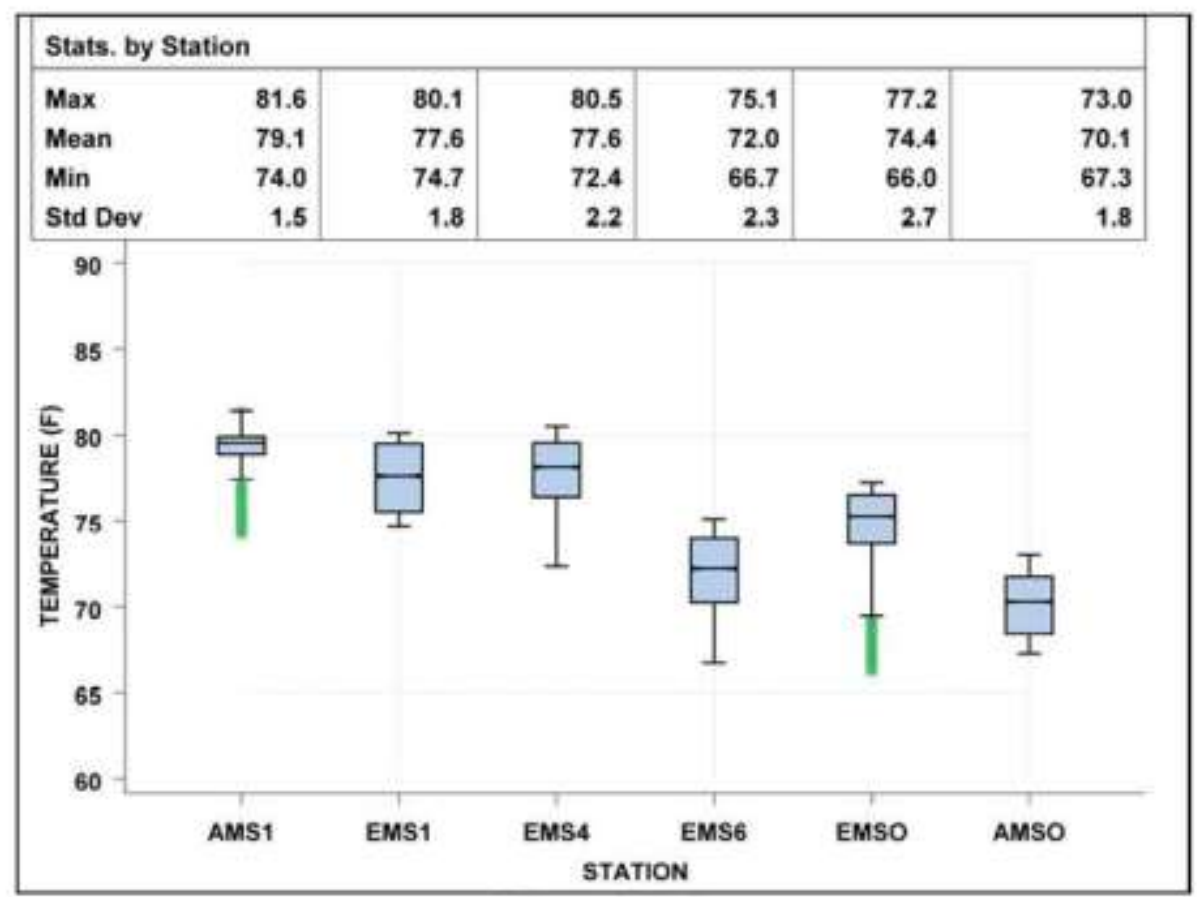

Figure 7 (c)

Figure 8. Descriptive statistics of water temperature in water 12 inch in the sediments as pump is (a) on, (b) off, and (c) on/ off.

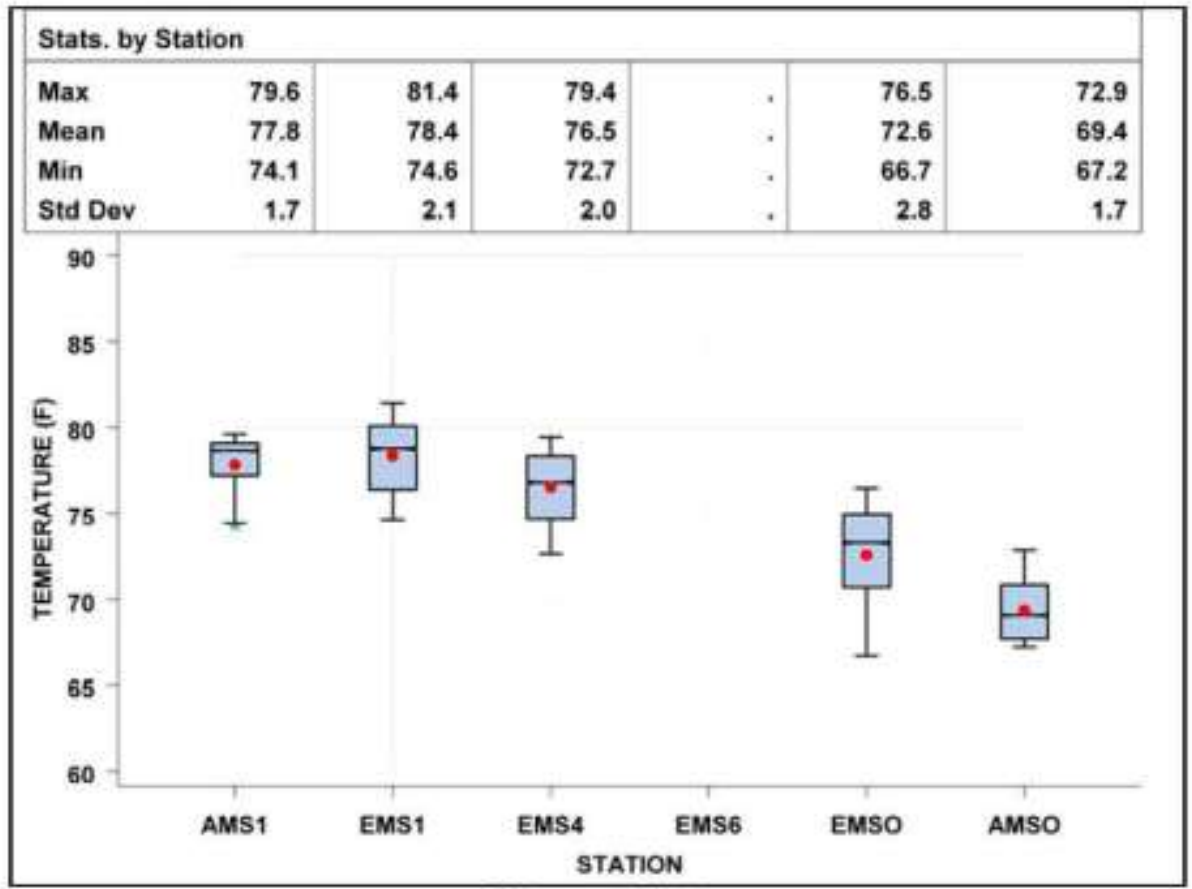

Figure 8 (a) 


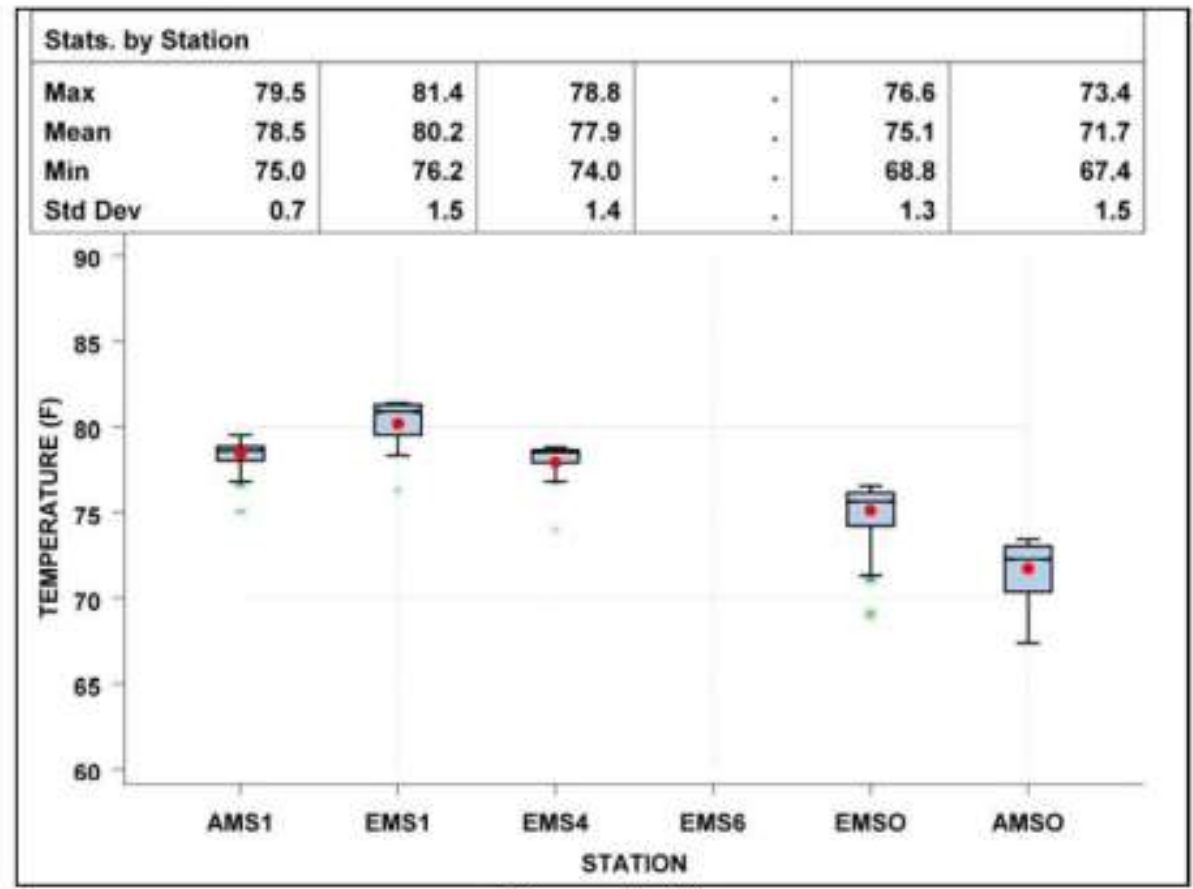

Figure 8 (b)

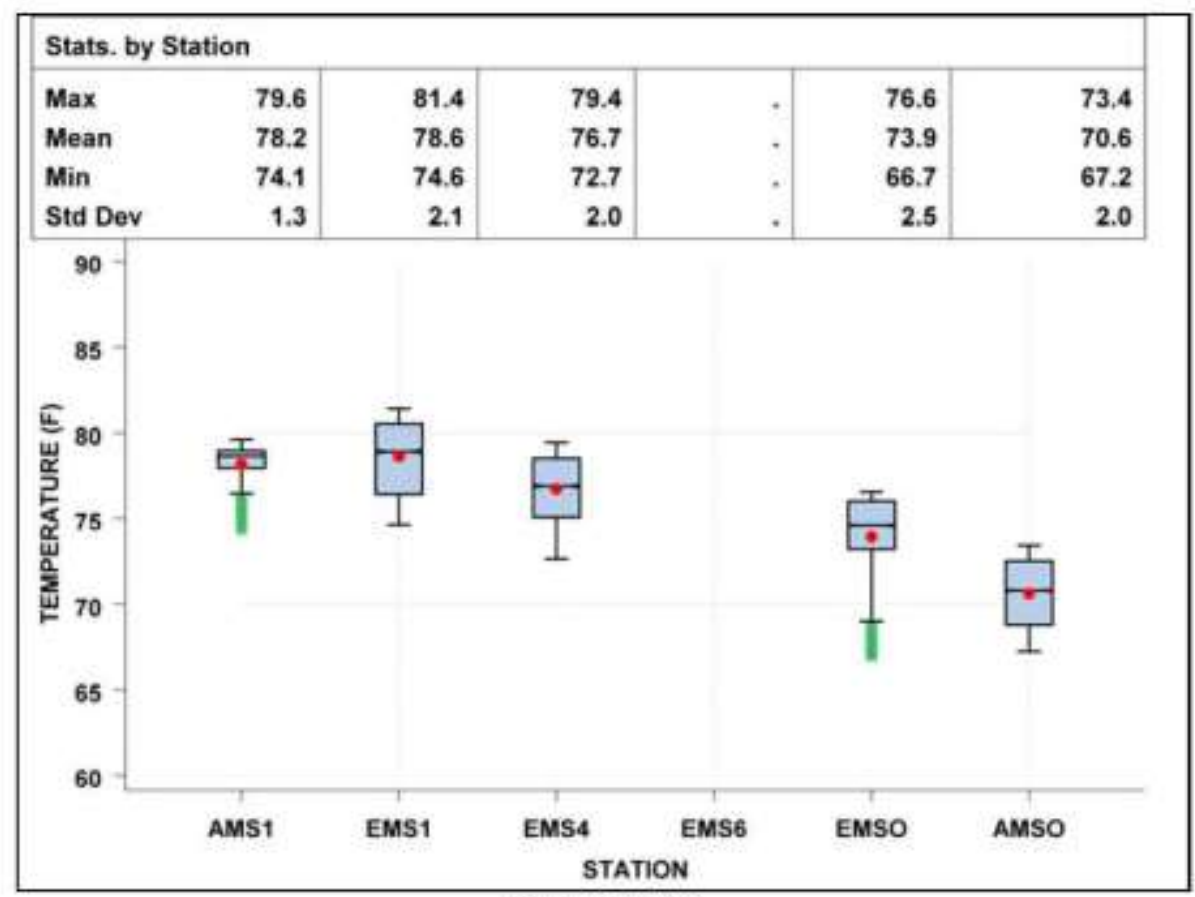

Figure 8 (c) 
Figure 9. Descriptive statistics of water temperature at bottom and at 3 inches above sediments as pump is (a) on, (b) off, and (c) on/off.

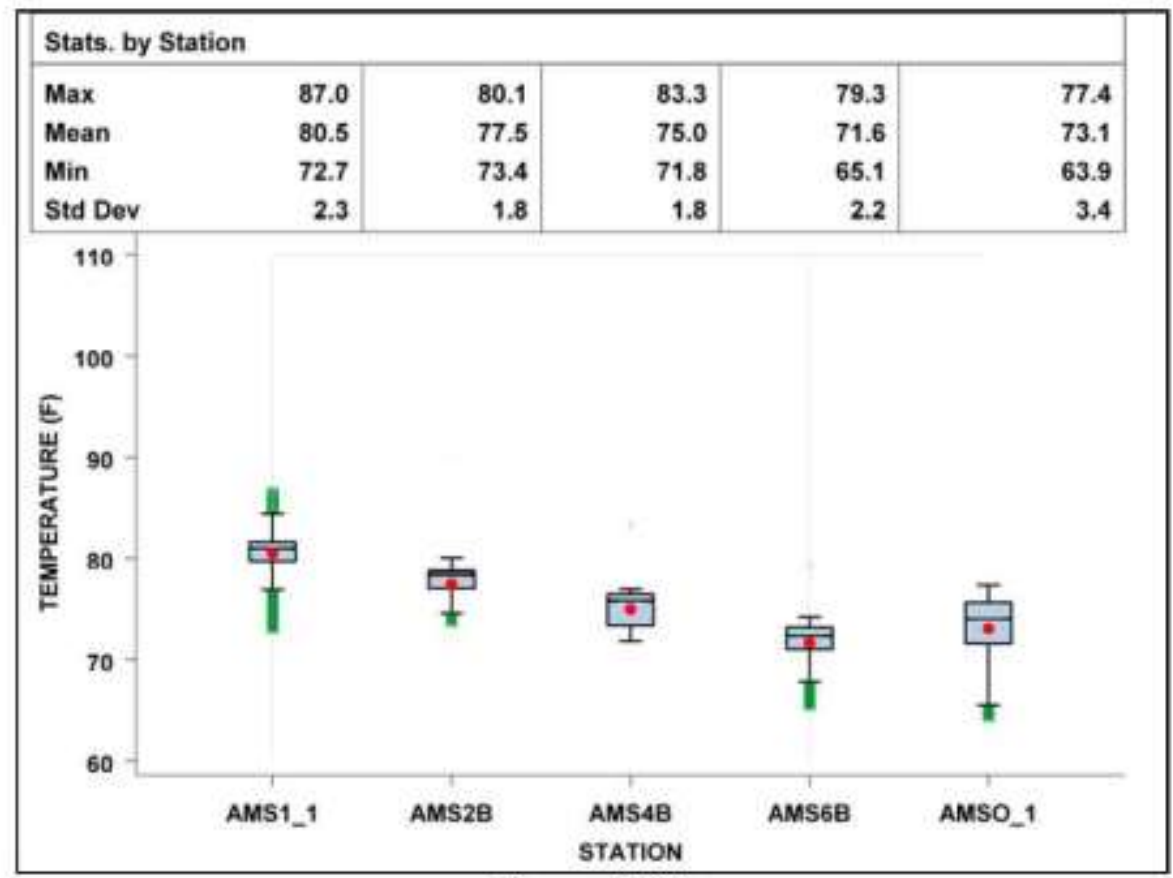

Figure 9 (a)

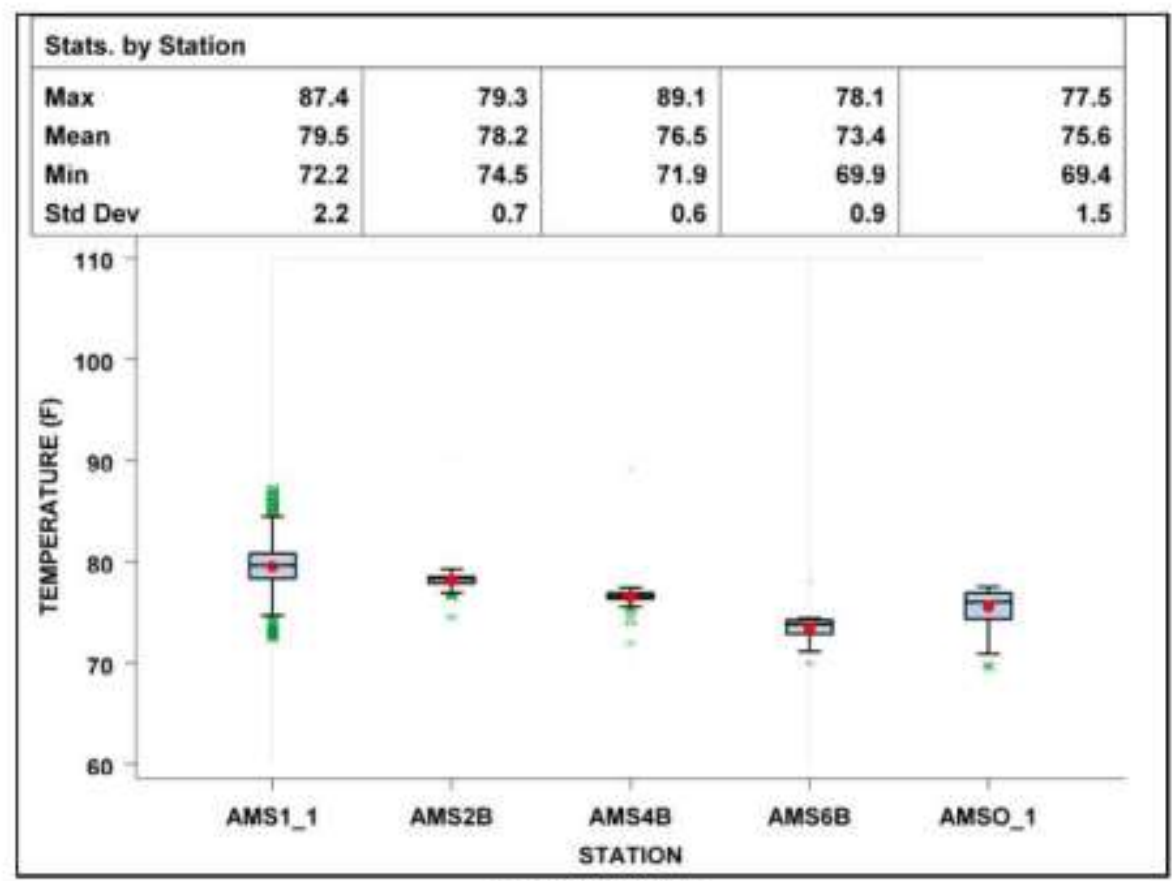

Figure 9 (b) 


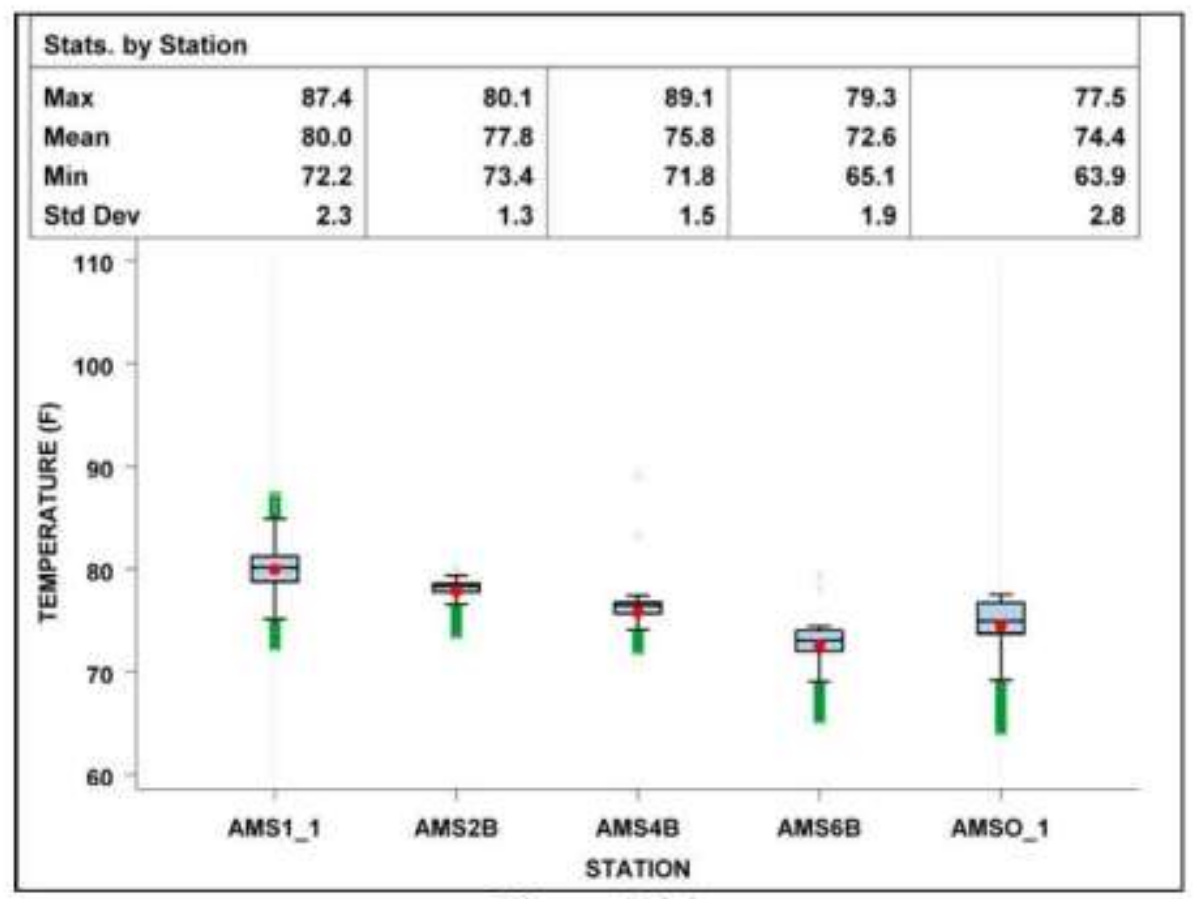

Figure 9 (c)

Figure 10. Difference in surface water temperature at the remaining stations with the inlet aquatic monitoring station.

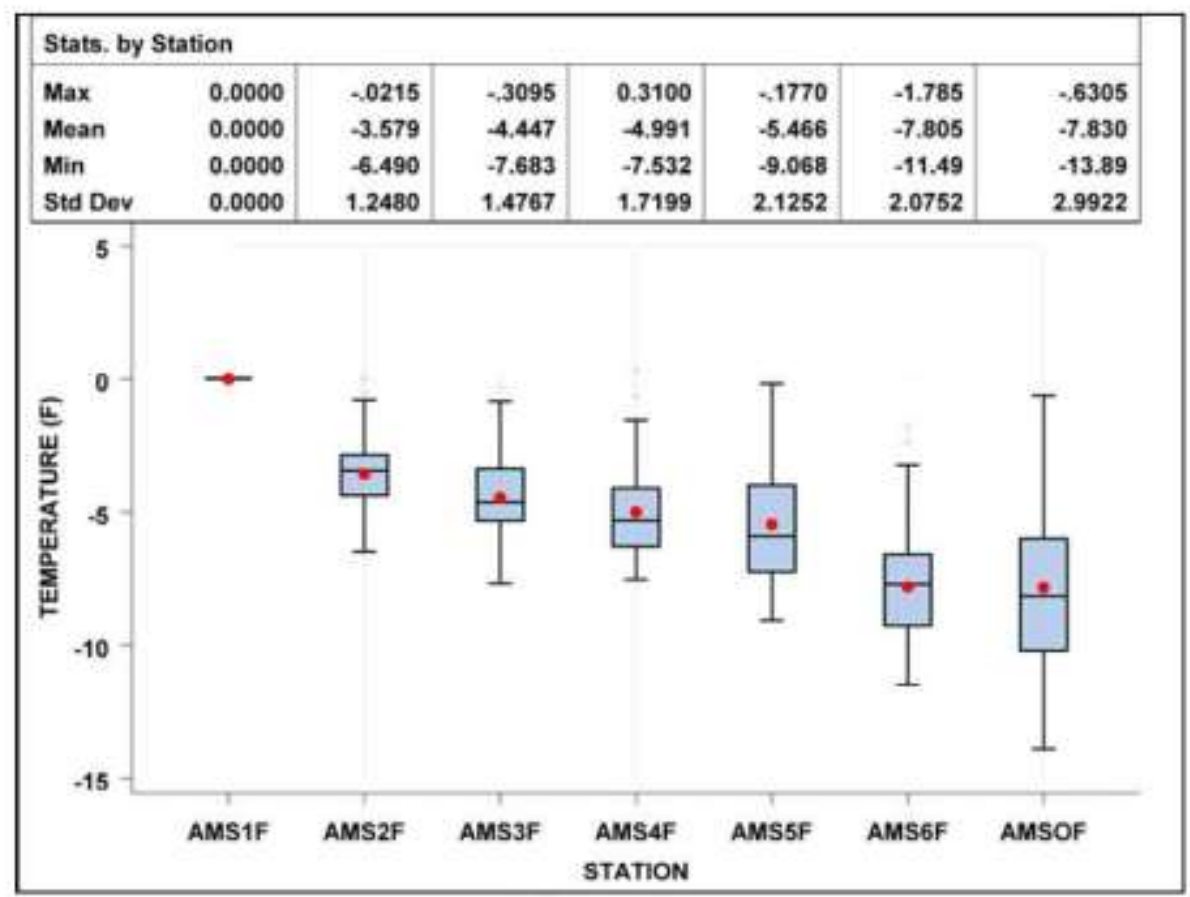

Figure 10 
Figure 11. Water cooling efficiency and difference in temperature at the inlet aquatic station with the remaining stations dividing by distance from the inset station to the remaining stations. The unit is temperature change per distance change $(\mathrm{F}$ m-1)

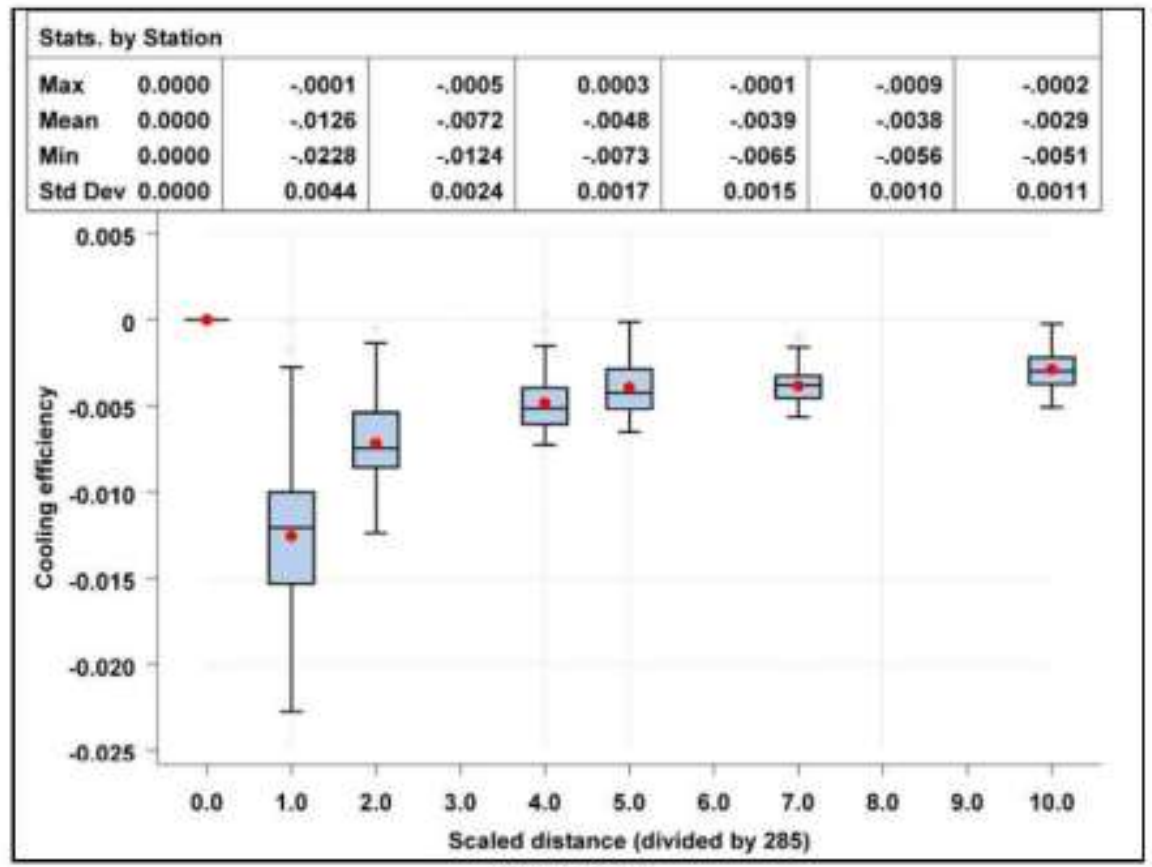

Figure 11 
Figure 12. Regression analysis of DAMS1OF with weather conditions and net water volume pumping in and out the track.
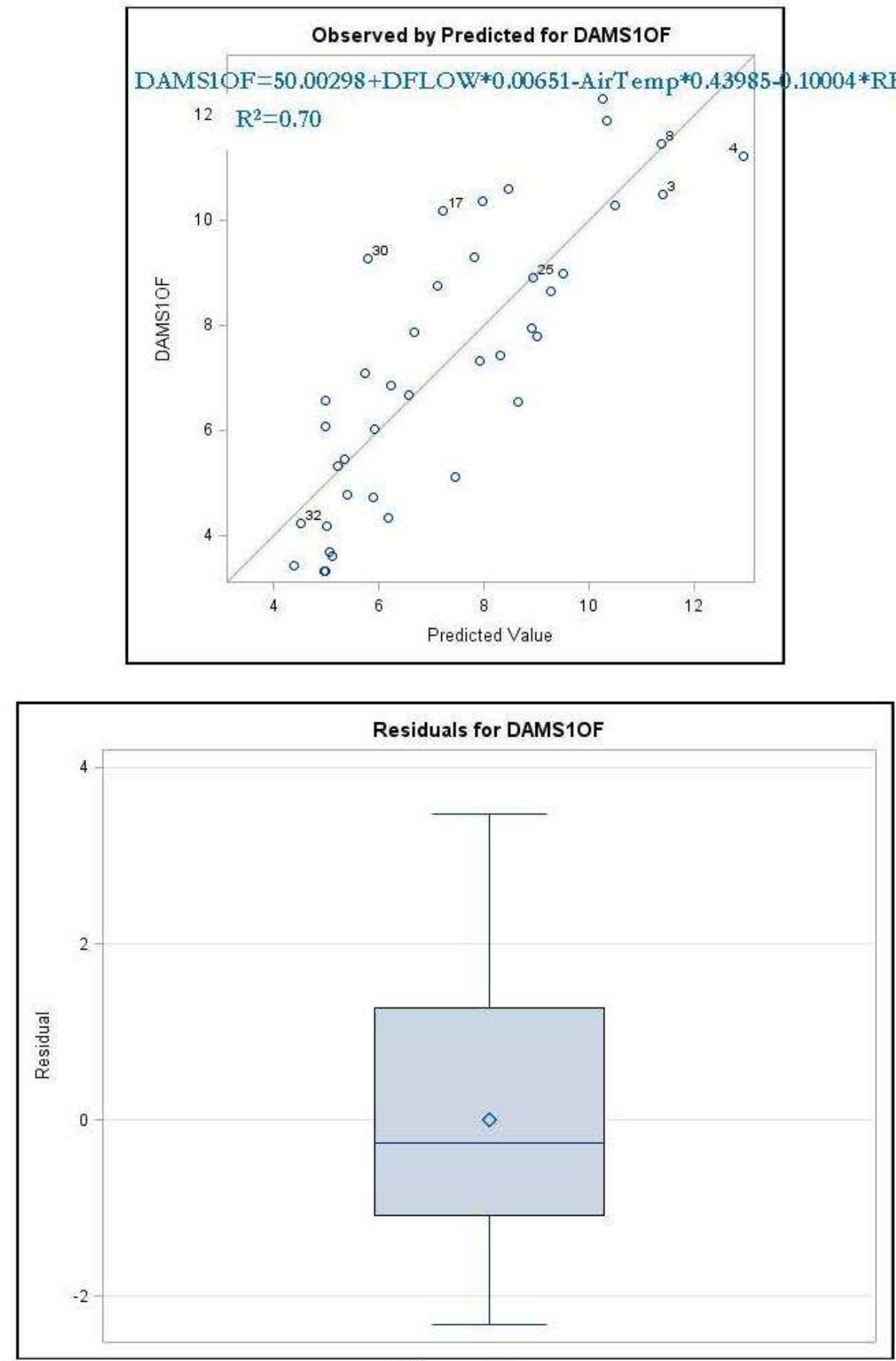

Figure 12 
Figure 13. Regression analysis of $\mathrm{DEMS} 1 \mathrm{OF}$ with weather conditions and net water volume pumping in and out the track.
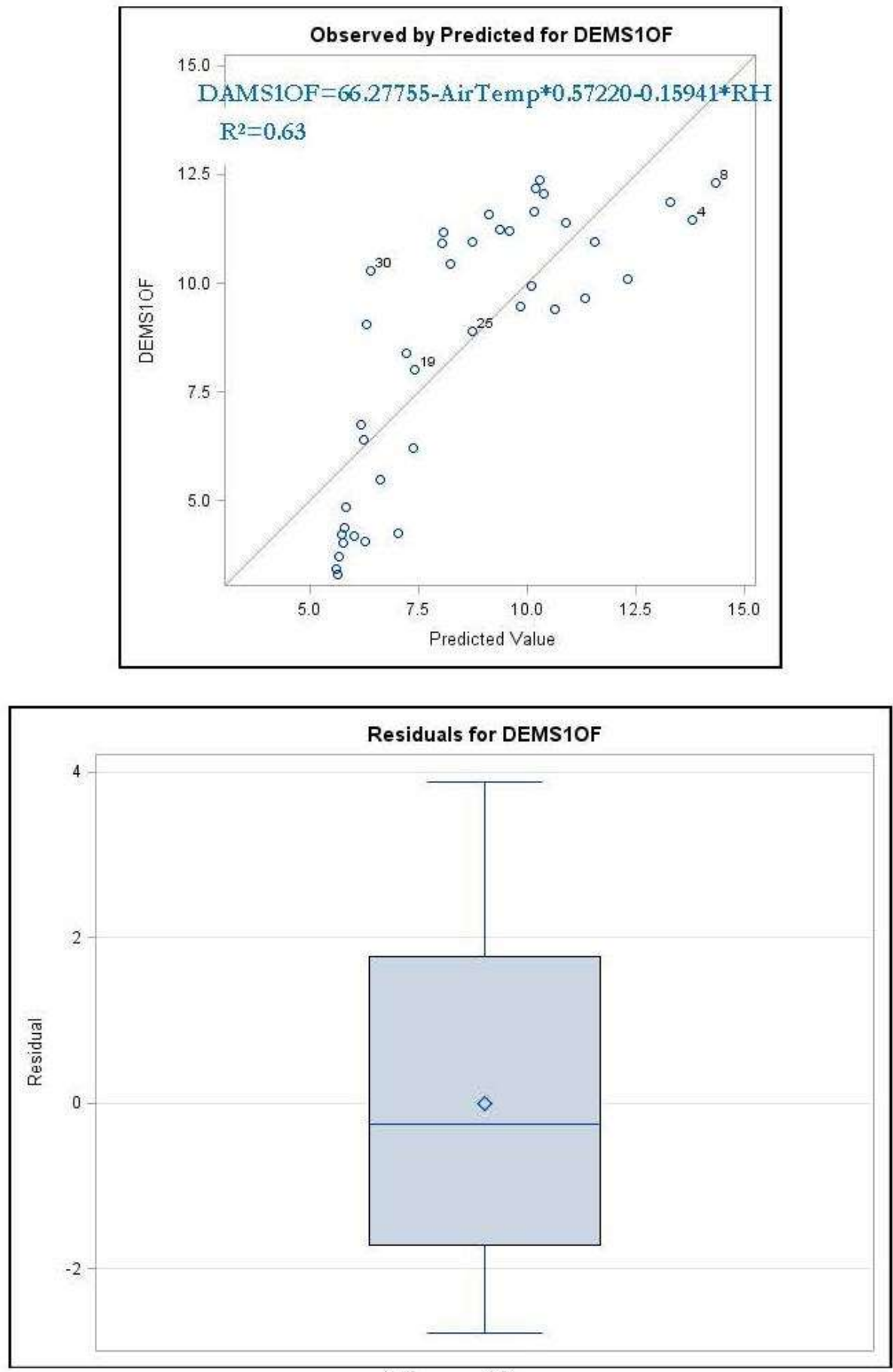

Figure 13 
Figure 14. Regression analysis of water temperature 3 inches above the sediments with weather conditions and net water volume pumping in and out the track.
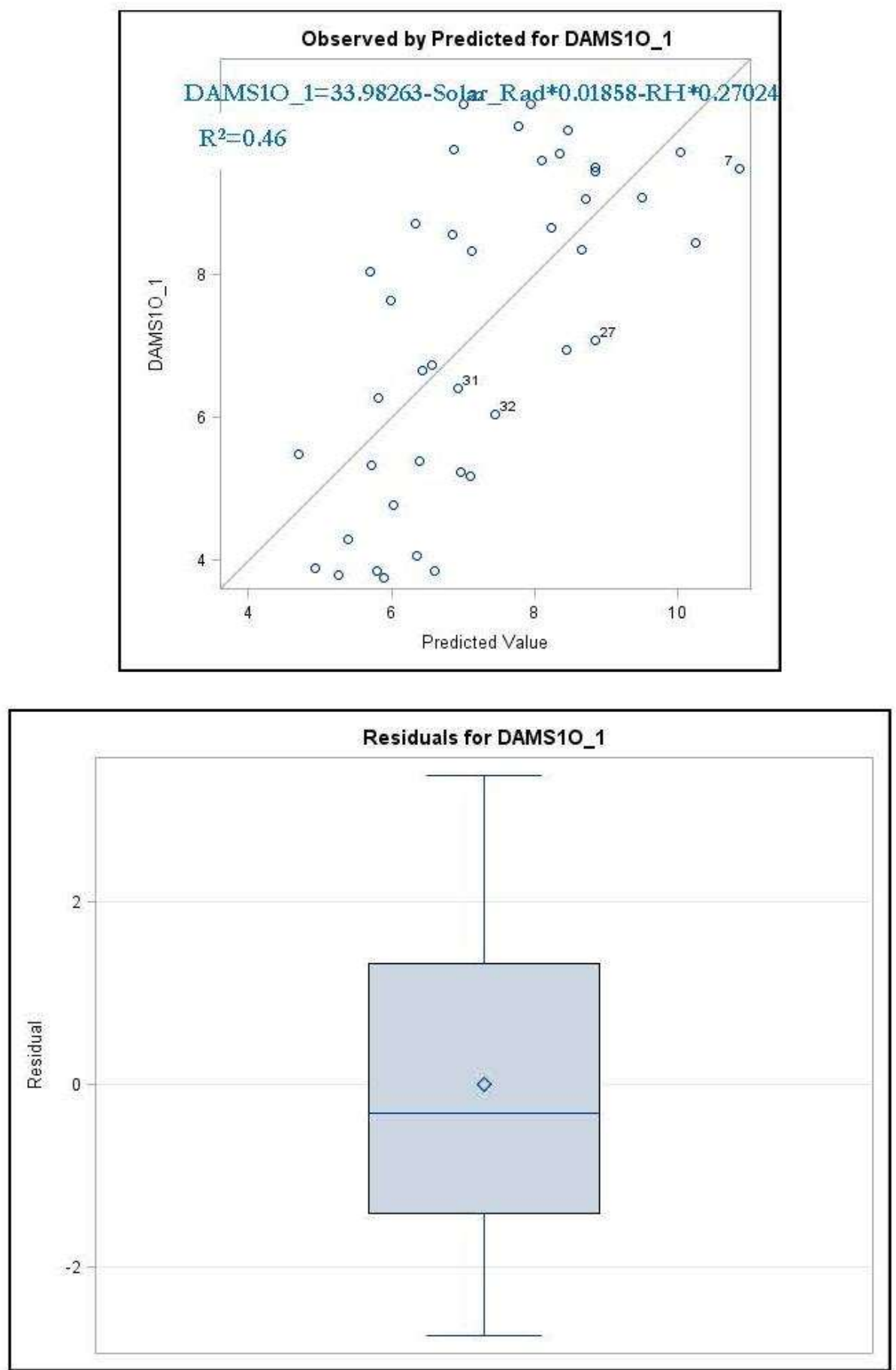

Figure 14 
Figure 15. Regression analysis of water temperature 3 inches in the sediments with weather conditions and net water volume pumping in and out the track.

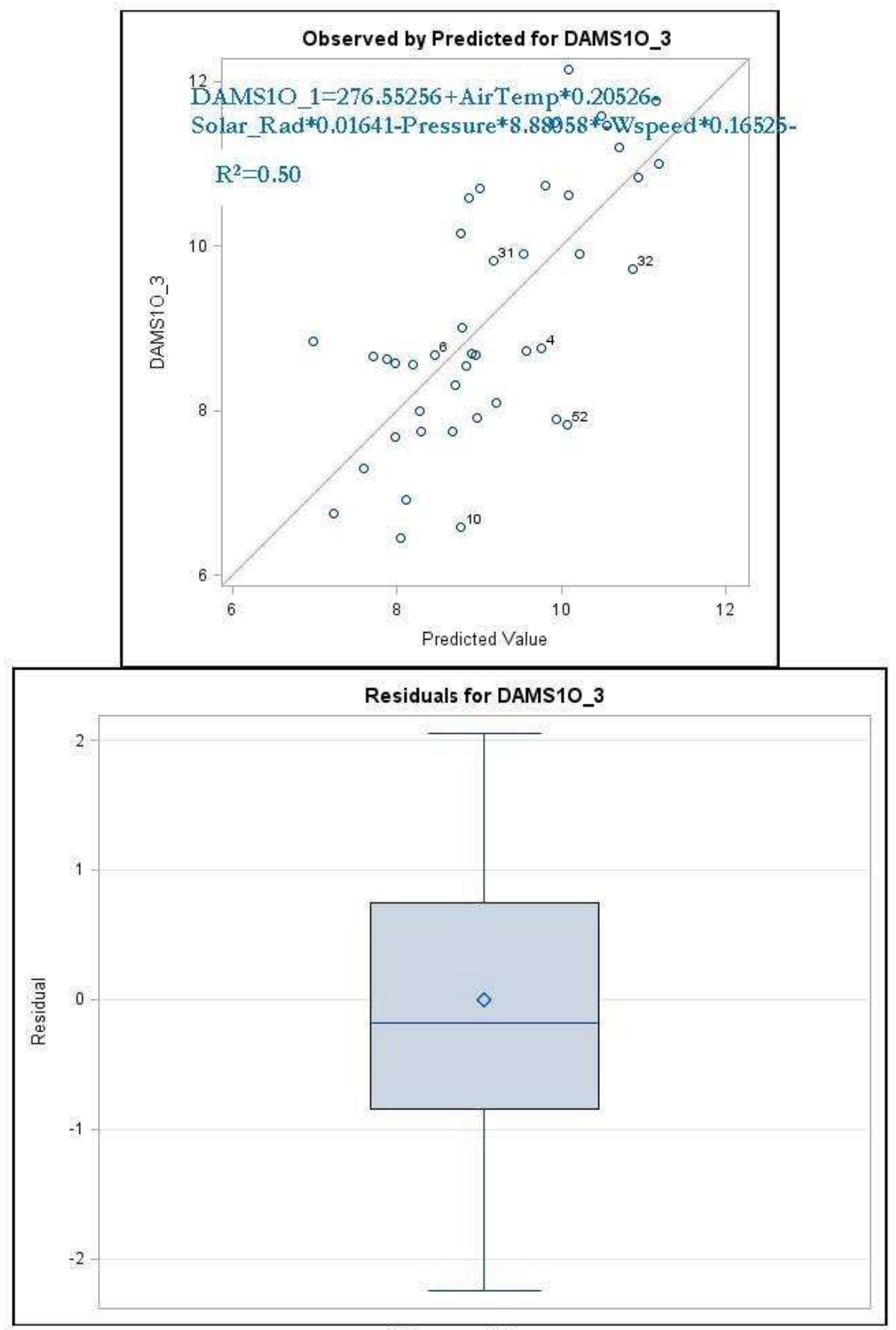

Figure 15 
Figure 16. Regression analysis of water temperature 12 inches in the sediments with weather conditions and net water volume pumping in and out the track.
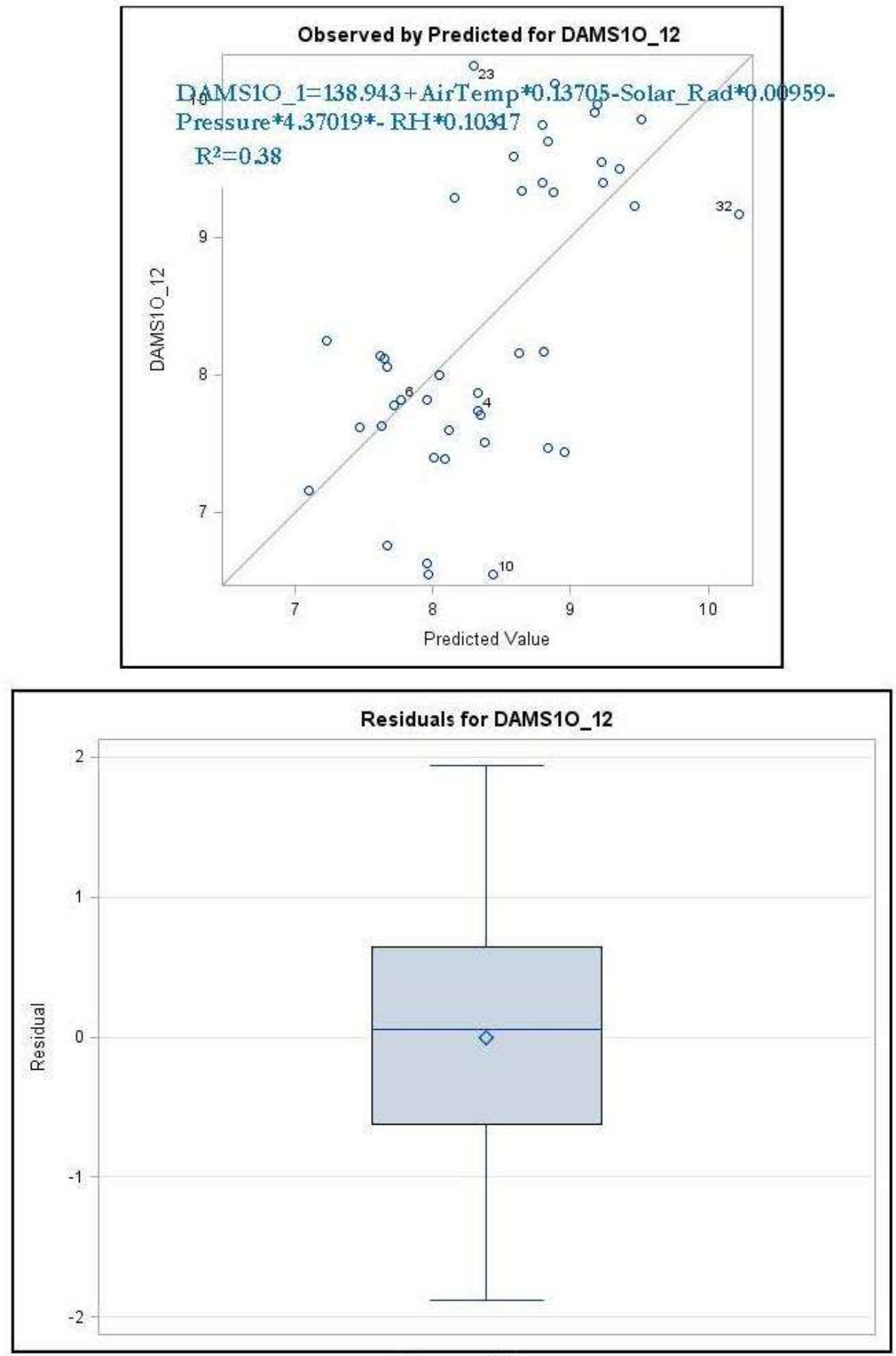

Figure 16 


\section{HINES ENERGY COMPLEX - RACETRACK WETLAND PHOTOS}

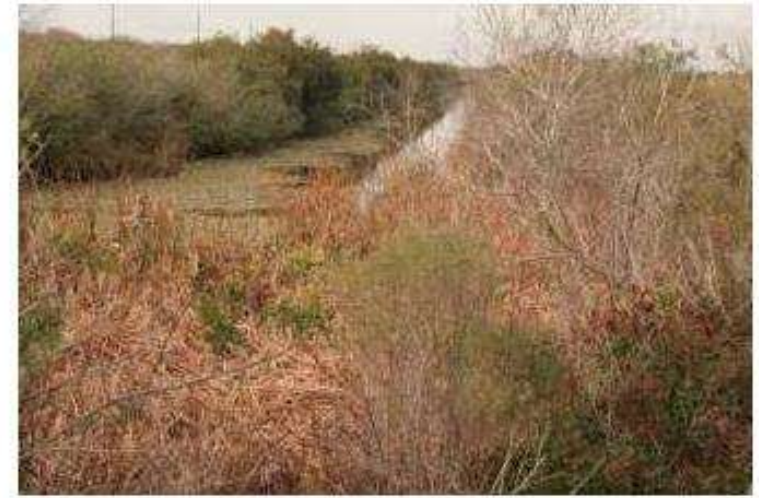

Race track Wetland Inlet

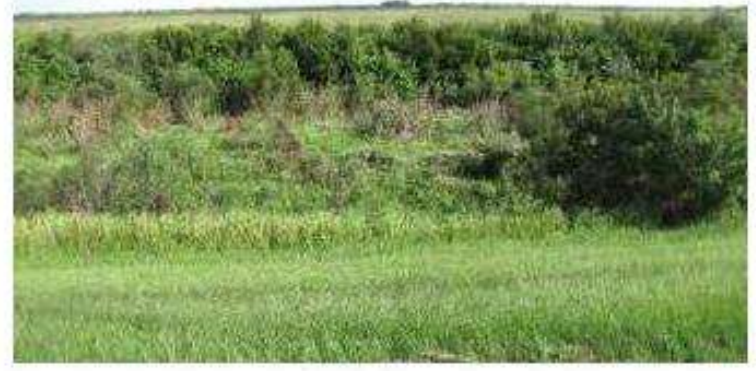

Race track Wetland South Channel from Above

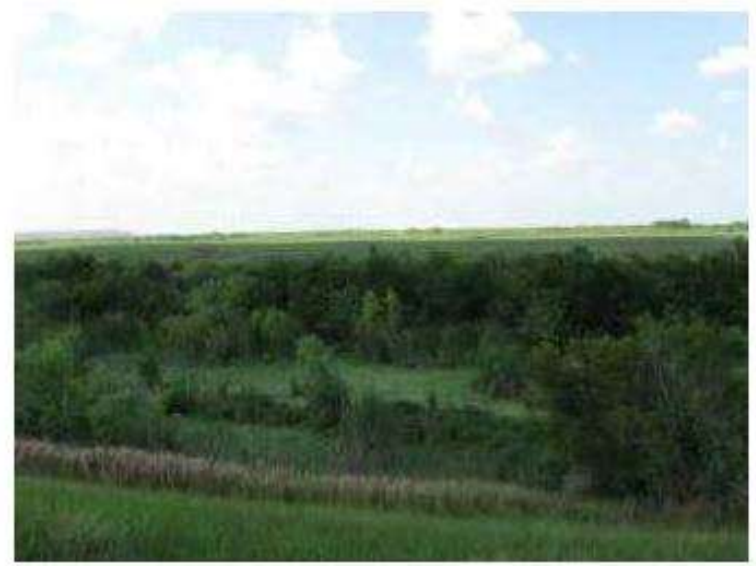

Race track Wetland South Channel from Abve

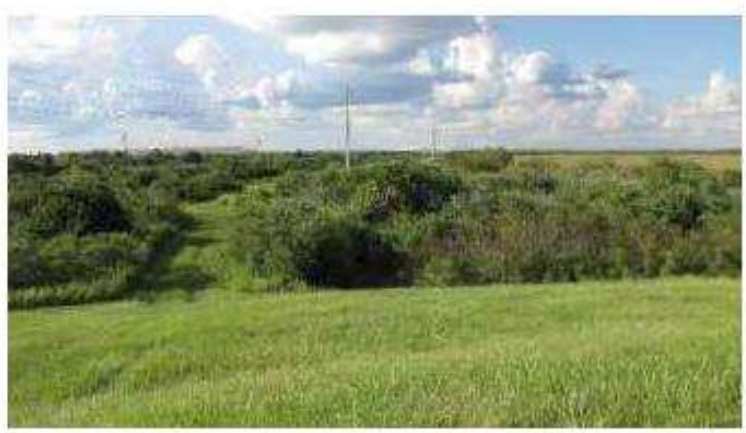

Race track Wetland at T urnaround Between Channels

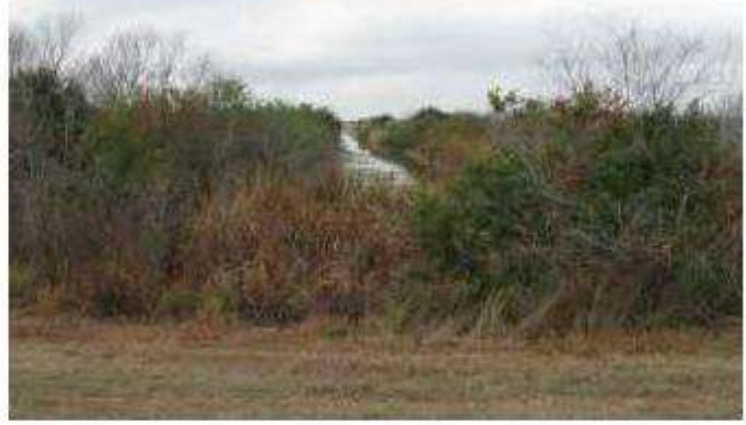

Race track Wetland Inlet

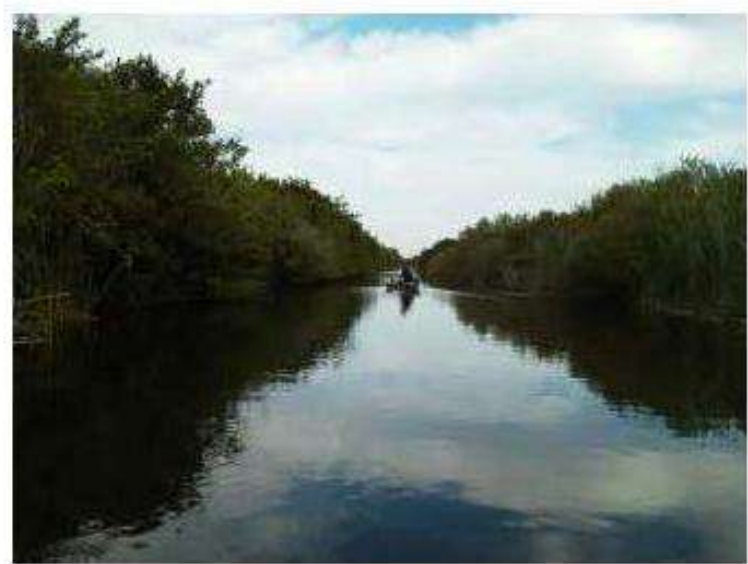

Race track Wetland Monitoring in North Channel 


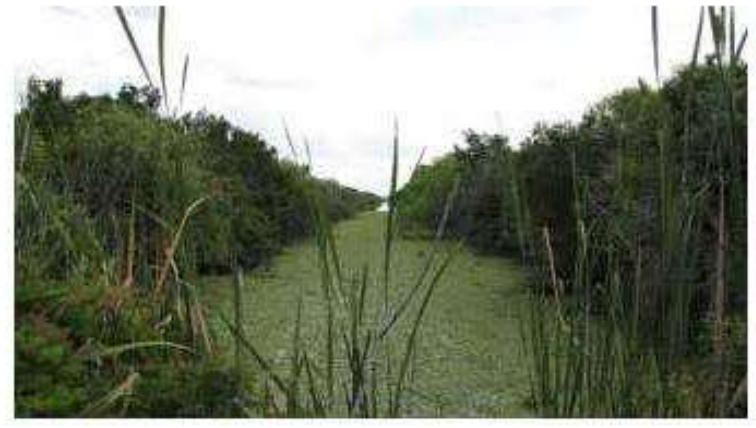

Race track Wetland Inlet

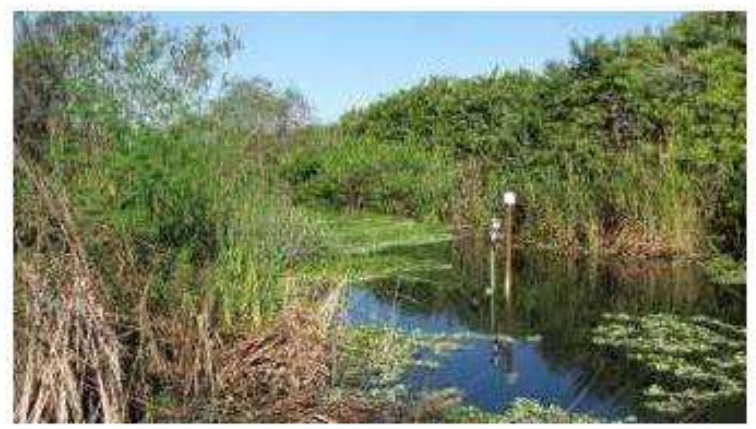

Race track Wetland Outlet Monitoring Station

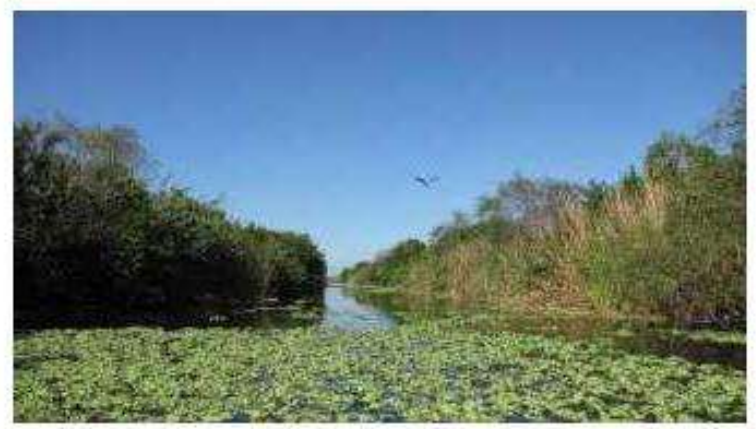

Race track Wetland North Channel

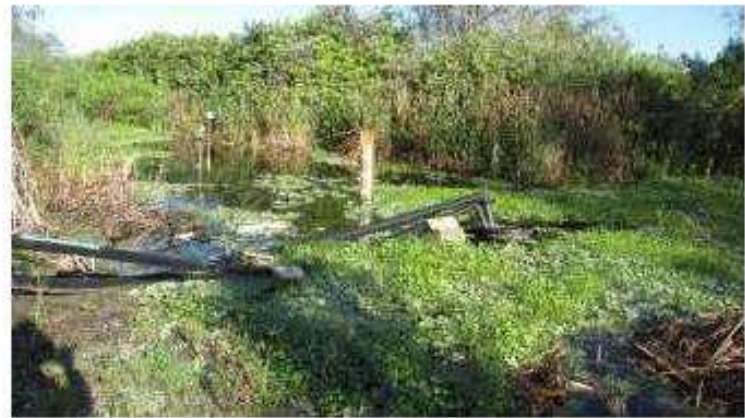

Racetrack Wetland Outlet and Pumps

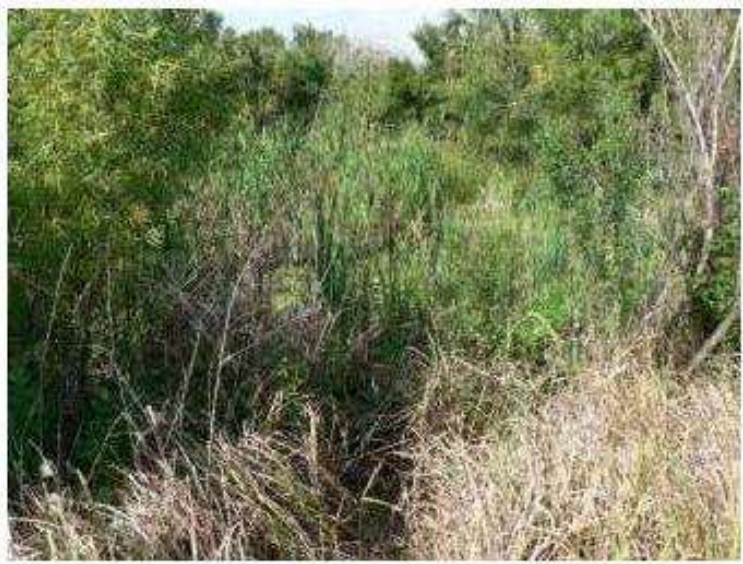

Racetrack Wetland South Channel

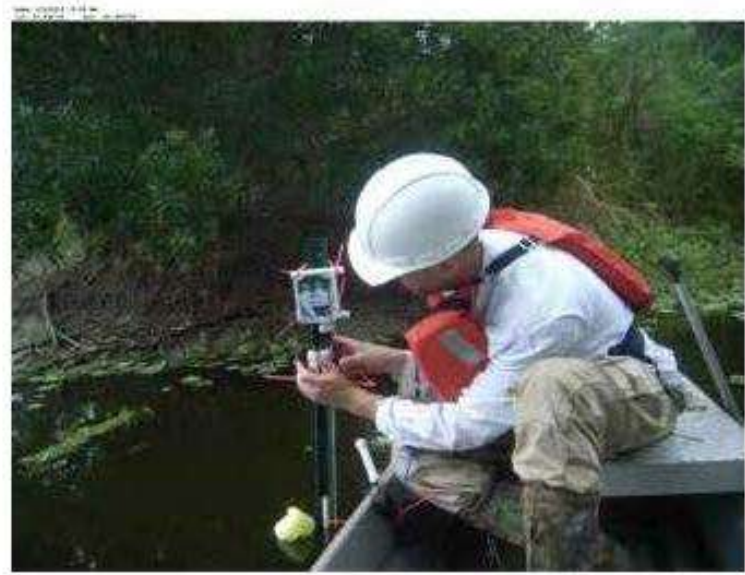

Race track Wetland Monitoring Intrument Installation 


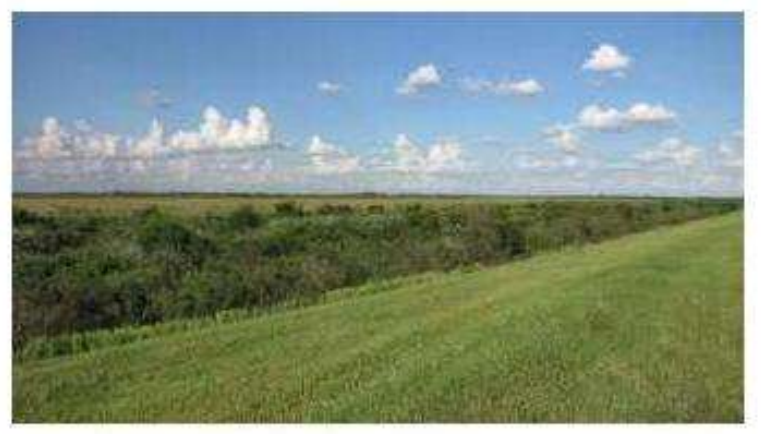

Race track Wetland from Bem

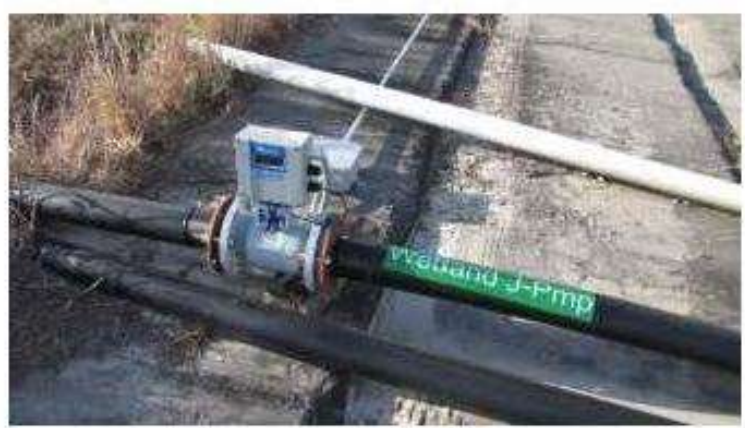

Race track Wetland Outlet Pump with Flow Meter

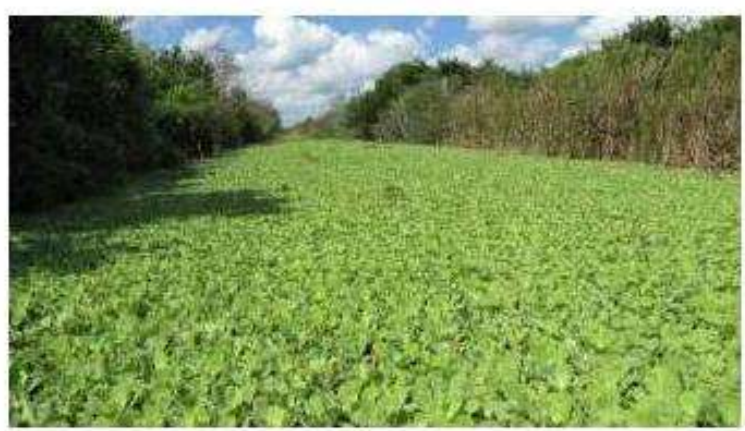

Race track Wetland Water Lettuce

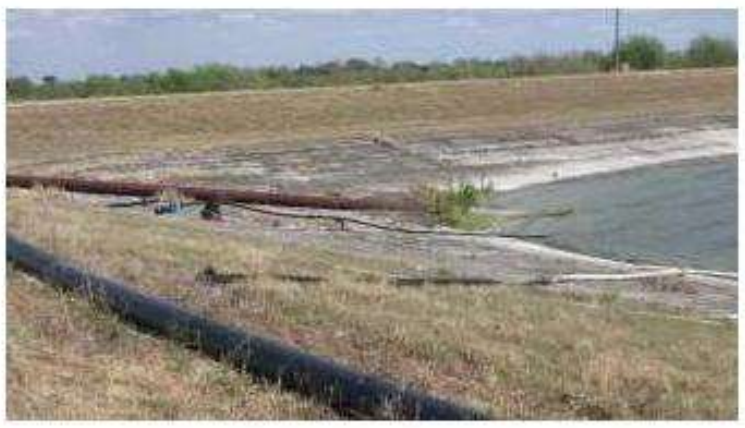

Racetrack Wetland Inlet Pump and Cooling Pond

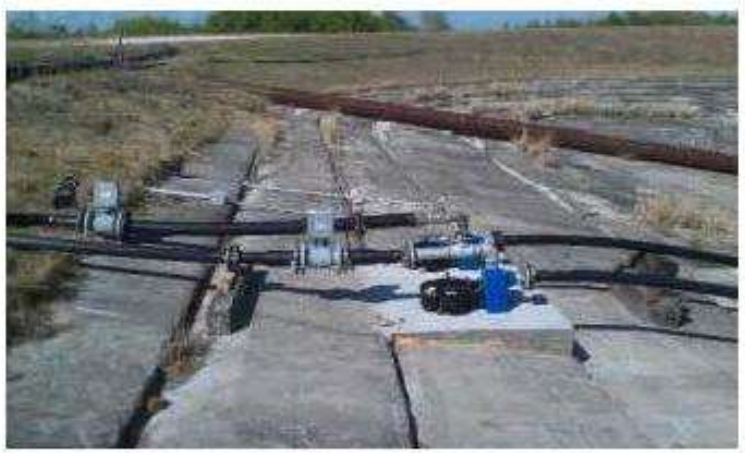

Race track Wetland Inlet and Outlet Pumps at Cooling Pond

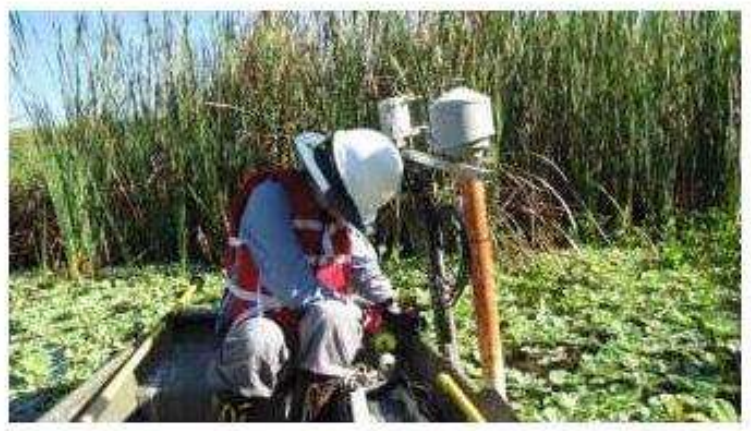

Race track Wetland Monitoring Data Collection 
WETLAND NATURAL RESOURCES INVENTORY RESULTS

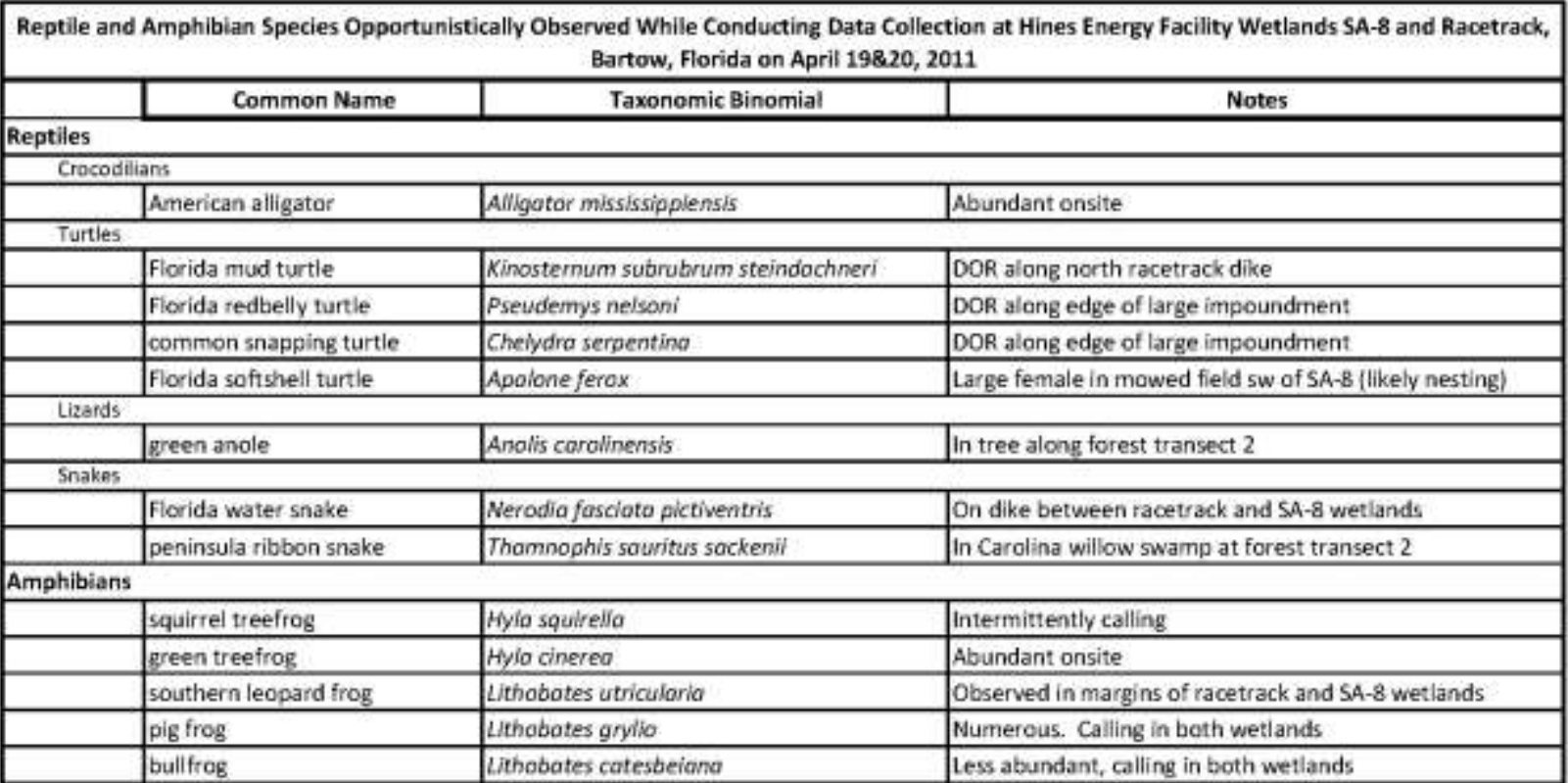




\begin{tabular}{|c|c|c|c|}
\hline \multicolumn{4}{|c|}{ Total Bird Species Observed at Hines Energy Facility, Bartow, Florida on April 19\&20, 2011} \\
\hline $\begin{array}{l}\text { ALPHA } \\
\text { CODE }\end{array}$ & Common Name & Taxonomic Binomial & Notes \\
\hline HOGR & horned grebe & Podiceps auritus & in SA-8 \\
\hline PBGR & pied-bilied grebe & Podilymbus podiceps & in SA-8 \\
\hline AWPE & American white pelican & Pelicanus erythrorhynchos & flocking and aggregating in large cooling basin \\
\hline BRPE & brown pelican & Pelicanus accidentalis & less abundant that AWPE in same locations \\
\hline DCCO & double-crested cormorant & Phalacrocorax auritus & throughout site in open waters \\
\hline ANHI & anhinga & Anhinga anhingo & throughout site in open waters \\
\hline AMBI & American bittern & Botaurus lentiginosus & flushed from wetland north of Racetrack Wetland \\
\hline GBHE & great blue heron & Ardea herodias & abundant onsite \\
\hline GREG & great egret & Ardea alba & abundant onsite \\
\hline SNEG & snowy egret & Egretta thula & abundant onsite \\
\hline TCHE & tricolored heron & Egretta tricolor & only three observed, along margin of large cooling, basin \\
\hline LBHE & little blue heron & Egretta caerulea & $\begin{array}{l}\text { 5parse but present, mostly along margin of large cooling } \\
\text { wetland }\end{array}$ \\
\hline CAEG & cattle egret & Bubulcus ibis & $\begin{array}{l}\text { sparse but present, mostly along margin of large cooling } \\
\text { wetland }\end{array}$ \\
\hline GRHE & green heron & Butorides virescens & in swamp within SA-B \\
\hline $\mathrm{BCNH}$ & black-crowned night heron & Nycticorax nycticorax & $\begin{array}{l}\text { commonly observed along margins of open waters } \\
\text { onsite }\end{array}$ \\
\hline WHIB & white ibis & Eudocimus albus & small flocks \\
\hline GLIB & glossy ibis & Plegadis folcinellus & small flocks \\
\hline ROSP & roseate spoonbill & Ajaia ajaia & $\begin{array}{l}\text { observed flying over site and foraging in margins of } \\
\text { large cooling basin }\end{array}$ \\
\hline WOST & wood stork & Mycteria americana & $\begin{array}{l}\text { observed flying over site and foraging in margins of } \\
\text { large cooling basin }\end{array}$ \\
\hline wodu & wood duck & Aix sponsa & $\begin{array}{l}\text { in emergent zones of study area and forested sWamps } \\
\text { of SA-8 }\end{array}$ \\
\hline MALL & mallard & Anas platyrhynchos & few pairs in cooling basin and SA- 8 \\
\hline MODU & mottled duck & Anas fulvigula & one pair in large cooling basin \\
\hline TuVu & turkey vulture & Cothartes aura & soaring overhead, possible roosting in SA-8 (north side) \\
\hline BLVU & black vulture & Coragyps atratus & soaring overhead, possible roosting in SA-8 (north side) \\
\hline RSHA & red-shouldered hawk & Buteo lineatus & calling from wetland west of SA-8 \\
\hline RTHA & red-tailed hawk & Buteo jamaicensis & few. Observed Aerial Foraging \\
\hline BAEA & bald eagle & Haliaeetus leucocephaius & 1st and 3rd year juveniles and two adult birds observed \\
\hline OSPR & osprey & Pandion haligetus & $\begin{array}{l}\text { numerous, Nest-building, courtship, territorial, and } \\
\text { food trasfer behavior observed }\end{array}$ \\
\hline PUGA & purple gallinule & Porphyrula martinica & $\begin{array}{l}\text { Less abundant than COMO, but present in emergent } \\
\text { zones of study area }\end{array}$ \\
\hline COMO & common moorhen & Gallinula chloropus & $\begin{array}{l}\text { commonly observed along margins of open waters } \\
\text { onsite }\end{array}$ \\
\hline AMCO & American coot & Fulica americano & $\begin{array}{l}\text { commonly observed along margins of open waters of SA } \\
8\end{array}$ \\
\hline VIRA & Virginia rail & Rallius limnicola & one observed along north margin of Racetrack Wetland \\
\hline SORA & sora & Porzana carolina & calling from west side of SA- 8 \\
\hline KILL & killdeer & Charadrius vociferus & aiong roads \\
\hline BNST & black-necked stilt & Himontopus mexiconus & $\begin{array}{l}\text { small flocks calling in flight, pairs foraging along margin } \\
\text { of large cooling basin }\end{array}$ \\
\hline
\end{tabular}




\begin{tabular}{|c|c|c|c|}
\hline LEYE & lesser yellowlegs & Tringa flavipes & foraging along margins of large cooling basin \\
\hline SOSA & solitary sandpiper & Tringa sailtaria & foraging along margins of large cooling basin \\
\hline SPSA & spotted sandpiper & Actitis macularia & foraging along margins of large cooling basin \\
\hline SESA & semipalmated sandpiper & Calidris pusilla & foraging akong margins of large cooling basin \\
\hline LESA & least sandpiper & Calidris minutilla & foraging along margins of large cooling basin \\
\hline LAGU & laughing gull & Larus atricilla & flying over \\
\hline \multicolumn{4}{|c|}{ GULLSP } \\
\hline CATE & caspian tern & Sterna caspia & $\begin{array}{l}\text { active foraging and roosting at large cooling basin and } \\
\text { SA-8 }\end{array}$ \\
\hline ROVT & royal tern & Stema maxima & $\begin{array}{l}\text { active foraging and rocsting at large cooling basin and } \\
\text { SA-9 }\end{array}$ \\
\hline COTE & common tern & Stema hirundo & $\begin{array}{l}\text { active foraging and roosting at large cooling basin and } \\
\text { sA-10 }\end{array}$ \\
\hline FOTE & Forster's tern & Stema forsteri & $\begin{array}{l}\text { active foraging and roosting at large cooling basin and } \\
\text { SA-11 }\end{array}$ \\
\hline LETE & least tern & Sterna antillarum & $\begin{array}{l}\text { active for aging and roosting at large cooling basin and } \\
\text { sA-12 }\end{array}$ \\
\hline BLSK & black skimmer & Rynchops niger & active foraging at dawn in SA-8 \\
\hline MODO & mourning dove & Zenaida macroura & singing from forests and powerlines \\
\hline WWDO & white-winged dove & Zenaida asiatica & singing from forests and powerlines \\
\hline ECDO & Eurasian collared dove & Streptopelia decoocto & $\begin{array}{l}\text { observed on powerlines between SA-8 and Racetrack } \\
\text { Wetland }\end{array}$ \\
\hline CGDO & common ground dove & Columbina passerina & $\begin{array}{l}\text { foraging along path and open area between } 5 \mathrm{~A}-8 \text { and } \\
\text { large cooling basin }\end{array}$ \\
\hline RBWO & red-bellied woodpecker & Melanerpes carolinus & in forest areas \\
\hline DOwo & downy woodpecker & Picoides pubescens & in forest areas \\
\hline NOFL & northern flicker & Colaptes auratus & in forested areas and open spaces foraging \\
\hline GCFL & great-crested flycatcher & Myiarchus crinitus & calling from willow forest \\
\hline EAKI & eastern kingbird & Tyrannus tyrannus & edge of SA-B \\
\hline LOSH & loggerhead shrike & Lanius ludovicianus & perched on power wires \\
\hline WEVI & white-eyed vireo & Vireo griseus & abundant onsite \\
\hline BUA & blue jay & Cyanocitta cristada & aburndant onsite \\
\hline FICR & fish crow & Corvus assifragus & abundant onsite \\
\hline PUMA & purple martin & Progne subis & foraging over SA-8 and large cooling basin \\
\hline BARS & barn swallow & Hirundo rustica & foraging over SA-8 and large cooling basin \\
\hline CAWR & Carolina wren & Thyrothorus ludovicianus & abundant onsite \\
\hline HOWR & house wren & Troglodytes aedon & two singing males \\
\hline SEWR & sedge wren & Cistothorus platensis & one singing male along edge of road on east side of SA-8 \\
\hline MAWR & marsh wren & Cistothorus palustris. & two males singing from cattails in SA-B \\
\hline BGGN & blue-gray gnatcatcher & Polioptïla caerulea & in willow swamp in SA-8 \\
\hline GRCA & Eray catbird & Dumetella camolinensis & forest edges \\
\hline NOMO & northern mockingbird & Mimus ployglottus. & forest edges \\
\hline PROW & prothonotary warbler & Protonotaria citrea & one male singing in NW part of SA-8 \\
\hline COYE & common yellowthroat & Geothlypis trichas & abundant onsite \\
\hline SUTA & summer tanager & Piranga rubra & one male singing in NW part of SA-8 \\
\hline NOCA & northern cardinal & Cardinalis cardinalis & abundant onsite \\
\hline EATO & eastern towhee & Pipilo erythrothaimus & abundant onsite \\
\hline BASP & Bachman's sparrow & Aimophila aestevalis & $\begin{array}{l}\text { Small concentration in scrubby area along path between } \\
\text { SA-8 and wetland to the west }\end{array}$ \\
\hline SOSP & song sparrow & Melaspiza melodia & abundant onsite \\
\hline SWSP & swamp sparrow & Melspiza georglano & edges of wetlands \\
\hline $\mathrm{BCBO}$ & bobolink & Dolichonyx oryzhorus & one flock flying overhead \\
\hline $\mathrm{BHCO}$ & brown-headed cowbird & Molothrus ater & abundant onsite \\
\hline RWBB & red-winged blackbird & Ageloius phoeniceus & abundant onsite \\
\hline COGR & common grackle & Quiscalus quisscula & abundant onsite \\
\hline BTGR & boat-tailed grackle & Quiscalus major & abundant onsite \\
\hline
\end{tabular}




\begin{tabular}{|c|c|c|c|}
\hline \multicolumn{4}{|c|}{$\begin{array}{l}\text { Mammal, Reptile and Amphibian Species Opportunistically Observed While Conducting Data Collection at Hines Energy } \\
\qquad \text { Facility Racetrack and SA-8 Wetlands, Bartow, Florida on April 16-20,2012 }\end{array}$} \\
\hline & Common Name & Taxonomic Binomial & \begin{tabular}{|c|} 
Notes \\
\end{tabular} \\
\hline \multicolumn{4}{|l|}{ Mammals } \\
\hline & eastern gray squirrel & Sciurus carolinensis & \\
\hline & opossum & Didelphis virginaina & \\
\hline & northern raccoon & Procyon fotor & observed at northern edge of SA-8 \\
\hline & northern river otter & Lontra canadensis & 3 observed at northwest end of racetrack \\
\hline & white-tailed deer & Odocoileus virginianus & $\begin{array}{l}\text { herd observed northeast of cooling pond. Many } \\
\text { tracks, scat, and trails observed onsite }\end{array}$ \\
\hline & feral pig & Sus scrofa & boar observed in SA-8 (dry) mudflats \\
\hline & bat 1 & & recorded in racetrack wetlands with Anabat \\
\hline & bat 2 & & recorded in racetrack wetlands with Anabat \\
\hline & bat 3 & & recorded in racetrack wetlands with Anabat \\
\hline & bat 4 & & recorded in racetrack wetlands with Anabat \\
\hline & bat 5 & & recorded in racetrack wetlands with Anabat \\
\hline & bat 6 & & recorded in racetrack wetlands with Anabat \\
\hline \multicolumn{4}{|l|}{ Reptiles } \\
\hline \multicolumn{4}{|c|}{ Crocodilians } \\
\hline & American alligator & Alligator mississippiensis & Abundant onsite \\
\hline \multicolumn{4}{|l|}{ Turtles } \\
\hline & Florida box turtle & Terropene corolino bouri & on road just southeat of site \\
\hline & peninsula cooter & Pseudemys floridona peninsuloris & basking in wetland north of RW \\
\hline & Florida redbelly turtle & Pseudemys nelsoni & DOR along edge of RW (in northwest corner) \\
\hline & Florida softshell turtle & Apalone ferox & 2 observed in SA-8, 1 in reclamation area \\
\hline \multicolumn{4}{|l|}{ Lizards } \\
\hline & green ancle & Anolis carolinensis & $\begin{array}{l}\text { western end of racetrack wetland in Typha and } \\
\text { cogon field }\end{array}$ \\
\hline & brown anole & Anolls sogrei & non-native in Florida \\
\hline & six-lined race runner & Cnemidophorus sexlineatus & cogon field south of racetrack wetland \\
\hline & Fence lizard spp. & Sceloporus spp. & cogon field south of racetrack wetland \\
\hline \multicolumn{4}{|l|}{ Snakes } \\
\hline & peninsular ribbon snake & Thamnophis sauritus sackenii & crossing access road northeast of cooling pond \\
\hline & southern black racer & Coluber constrictor priapus & identified from shed found in cogon field \\
\hline & Florida kingsnake & Lampropeltis getulus floridano & $\begin{array}{l}\text { identified from shed found onsite at western } \\
\text { edge of racetrack wetland }\end{array}$ \\
\hline \multicolumn{4}{|c|}{ Amphibians } \\
\hline & squirrel treefrog & Hyla squirello & Intermittently calling \\
\hline & green treefrog & Hyla cinerea & abundant onsite \\
\hline & southern leopard frog & Lithobates utricularia & few heard calling \\
\hline & pig frog & Lithobates grylio & Numerous. Calling in both wetlands \\
\hline & bullfrog & Lithobates catesbeiana & Less abundant, calling in both wetlands \\
\hline
\end{tabular}




\begin{tabular}{|c|c|c|c|}
\hline \multicolumn{4}{|c|}{ Total Bird Species Observed at Hines Energy Facility, Bartow, Florida on April 16-20, 2012} \\
\hline $\begin{array}{l}\text { ALPHA } \\
\text { CODE }\end{array}$ & Common Name & Taxonomic Binomial & Notes \\
\hline AWPE & American white pelican & Pelicanus erythrorhynchos & flocking and aggregating in large cooling basin \\
\hline BRPE & brown pelican & Pelicanus occidentalis & less abundant that AWPE in same locations \\
\hline ANHI & anhinga & Anthinga anhinga & $\begin{array}{l}\text { throughout site in open waters. Territorial in reclamation } \\
\text { wetland }\end{array}$ \\
\hline DCCO & double-crested cormorant & Phalacrocorax auritus & $\begin{array}{l}\text { throughout site in open waters, Lots of daily movement to } \\
\text { and from the site. }\end{array}$ \\
\hline AMBI & American bittern & Botaurus lentiginosus & flushed from wetland north of Racetrack Wetland \\
\hline LEBI & least bittern & Ixobrychus exilis & $\begin{array}{l}\text { probable breeder in SA-8 - reperched in Typha. Also in } \\
\text { reclamation area }\end{array}$ \\
\hline GBHE & great blue heron & Ardea herodias & abundant onsite \\
\hline GREG & great egret & Ardea alba & abundant onsite \\
\hline SNEG & snowy egret & Egretto thula & abundant onsite \\
\hline LBHE & little blue heron & Egretto coerulea & regular onsite \\
\hline TRHE & tricolored heron & Egretto tricolor & regular onsite \\
\hline CAEG & cattle egret & Bubulcus ibis & $\begin{array}{l}\text { sparse but present, mostly along margin of large cooling } \\
\text { wetland }\end{array}$ \\
\hline GRHE & green heron & Butorides virescens & regular onsite \\
\hline $\mathrm{BCNH}$ & black-crowned night heron & Nycticorax mycticorax & $\begin{array}{l}\text { commonly observed along margins of open waters onsite; } \\
\text { abundant roosting in east end of racetrack }\end{array}$ \\
\hline GLIB & glossy ibis & Plegadis falcinellus & small flocks \\
\hline WHIB & white ibis & Eudocimus aibus & small flocks \\
\hline ROSP & roseate spoonbill & Ajaia ajoia & $\begin{array}{l}\text { observed flying over site and foraging in margins of large } \\
\text { cooling basin }\end{array}$ \\
\hline WOST & wood stork & Mycteria americana & $\begin{array}{l}\text { observed flying over site and foraging in margins of large } \\
\text { cooling basin }\end{array}$ \\
\hline WODU & wood duck & Aix sponsa & two flying over wetland nor th of RW $4 / 20$ \\
\hline MALL & mallard & Anas brachyrhincos & few onsite \\
\hline MODU & mottled duck & Anas fulvigula & one pair in large cooling basin \\
\hline BWTE & blue winged teal & Anas discors & 2 drake, 3 hen in reclamation area \\
\hline BHGO & bar-headed goose & Anser indicus & introduced to region. Flock of 7 flyover \\
\hline Duck sp. & unknown duck species & & distant ducks in cooling pond; flyover species \\
\hline UNDU & unidentified duck sp. & & $\begin{array}{l}\text { underwing black, with white flashes in flight, gray-ish neck } \\
\text { and head impression (BWDU???) }\end{array}$ \\
\hline BLVU & black vulture & Coragyps atratus & soaring overhead \\
\hline TUVU & turkey vulture & Cothartes aura & soaring overhead \\
\hline OSPR & osprey & Pandion haliaetus & abundant onsite \\
\hline STKI & swallow-tailed kite & Elanoides forficatus & observed offsite during trip \\
\hline $\mathrm{COHA}$ & Cooper's hawk & Accipiter cooperii & observed offsite during trip \\
\hline NOHA & northern harrier & Cïrcus cyaneus & several observed onsite \\
\hline RSHA & red-shouldered hawk & Buteo lineatus & observed offsite during trip \\
\hline RTHA & red-talled hawk & Buteo jamaicensis & observed perched adjacent to site along CR555 \\
\hline BAEA & bald eagle & Halioeetus leucocephalus & 2nd to 3rd year juvenile observed \\
\hline WITU & wild turkey & Meleagris gallopavo & observed offsite on mined land during trip \\
\hline
\end{tabular}




\begin{tabular}{|c|c|c|c|}
\hline NOBO & northern bobwhite & Colinus virginianus & observed offsite on mined land during trip \\
\hline COMO & common moorhen & Gallinula chloropus & commonly observed along margins of open waters onsite \\
\hline PUGA & purple gallinule & Porphyrula martinica & $\begin{array}{l}\text { Less abundant than COMO, but present in emergent zones } \\
\text { of study area }\end{array}$ \\
\hline AMCO & American coot & Fulico americana & occasionally observed onsite \\
\hline SACR & sandhill crane & Grus canadensis & observed offsite during trip \\
\hline KILL & killdeer & Charadrius vociferus & along roads \\
\hline BNST & black-necked stilt & Himantopus mexicanus & $\begin{array}{l}\text { small flocks calling in flight, pairs foraging along margin of } \\
\text { large cooling basin }\end{array}$ \\
\hline GRYE & greater yellowiegs & Tringa melanoleuca & foraging along margins of large cooling pond \\
\hline LEYE & lesser vellowlegs & Tringa flavipes & foraging along margins of large cooling pond \\
\hline SOSA & solitary sandpiper & Tringa soiltaria & foraging along margins of large cooling pond \\
\hline SPSA & spotted sandpiper & Actitis macularia & foraging along margins of large cooling pond \\
\hline DUNL & dunlin & Calidris alpina & observed in reclamation are wetland on $4 / 20$ with SBDO \\
\hline SESA & semipalmated sandpiper & Calidris pusilla & foraging along margins of large cooling pond \\
\hline LESA & least sandpiper & Calidris minutillo & foraging along margins of large cooling pond \\
\hline Calidris spp. & Calidris sandpiper species & Colidris spp. & foraging along margins of large cooling pond \\
\hline SBDO & short-billed dowitcher & Limnodromus griseus & foraging along mudflats in reclamation area \\
\hline $\begin{array}{c}\text { Shorebird } \\
\text { spp. }\end{array}$ & Shorebird species & & foraging along margins of large cooling pond \\
\hline LAGU & laughing gull & Larus atricilia & active foraging and roosting at large cooling pond \\
\hline RBGU & ring-billed gull & Larus delawarensis & active foraging and roosting at large cooling pond \\
\hline Gull spp. & Gull species & Larus species & unidentified distant flyovers \\
\hline CATE & casplan tern & Sterna casplo & active foraging and roosting at large cooling pond \\
\hline COTE & common tern & Sterna hirundo & immature/molting bird foraging northeast of coolong pond \\
\hline FOTE & Forster's tern & Sterna forsteri & active foraging and roosting at large cooling pond \\
\hline LETE & least tern & Sterna antillarum & active foraging and roosting at large cooling pond \\
\hline BLSK & black skimmer & Rynchops niger & flyover of 5 during early AM point counts \\
\hline WWDO & white-winged dove & Zenaida asiatico & singing from forests and powerlines \\
\hline MODO & mourning dove & Zenaida macroura & singing from forests and powerlines \\
\hline CGDO & common ground dove & Cofumbina passerina & foraging along roads around SA-8 and cooling pond \\
\hline YBCU & yellow-billed cuckoo & Coccyzus americanus & $\begin{array}{l}\text { observed along racetrack wetland shrubs/ singing from SA-8 } \\
\text { forest }\end{array}$ \\
\hline GHOW & great-horned owl & Bubo virgianicus & reclamation area and abandoned osprey nest offsite \\
\hline CHSW & chimney swift & Chaetura pelagica & observed offsite \\
\hline BEKI & belted kingfisher & Ceryle alcyon & observed in racetrack wetland \\
\hline RBWO & red-bellied woodpecker & Melanerpes carolinus & in forest areas \\
\hline DOWO & downy woodpecker & Picoides pubescens & in forest areas \\
\hline NOFL & northern flicker & Colaptes ouratus & in forested areas and open spaces foraging \\
\hline PIWO & pileated woodpecker & Dryocopus pileatus & calling from $5 A-8$ forest \\
\hline GCFL & great-crested flycatcher & Myiarchus crinitus & breding pair in willow forest along west edge of SA-8 \\
\hline EAKI & eastern kingbird & Tyrannus tyrannus & edge of SA-8 \\
\hline
\end{tabular}




\begin{tabular}{|c|c|c|c|}
\hline GRKI & gray kingbird & Tyrannus dominicensis & $\begin{array}{l}\text { single individual observed onsite near NE corner of cooling } \\
\text { pond }\end{array}$ \\
\hline LOSH & loggerhead shrike & Lanius Iudovicianus & perched / hunting along entry road; breeding confirmed \\
\hline WEVI & white-eyed vireo & Vireo griseus & abundant onsite \\
\hline YTVI & yellow-throated vireo & Vireo flavifrons & heard from brine pond $/ 5 \mathrm{~A}-\mathrm{B}$ \\
\hline BHVI & blue-headed vireo & Vireo solitarius & heard from SA-8 (1) \\
\hline BUA & blue jay & Cyanocitto cristada & abundant onsite \\
\hline AMCR & American crow & Corvus brachyrhynchos & several observed onsite \\
\hline FICR & fish crow & Corvus ossifragus & abundant onsite \\
\hline PUMA & purple martin & Progne subis & foraging over cooling pond; nesting in power poles \\
\hline BARS & barn swallow & Hirundo rustica & several observed onsite \\
\hline BANS & bank swallow & Riparia riparia & abundant onsite \\
\hline TRES & tree swallow & Tachycineta bicolor & abundant onsite \\
\hline $\begin{array}{l}\text { Swaliow } \\
\text { spp. }\end{array}$ & Swallow species & & unidentified distant flyovers and perched swallows \\
\hline $\mathrm{CACH}$ & Carolina chickadee & Poecile carolinensis & heard in racetrack wetland \\
\hline TUTI & tufted titmouse & Baeolophus bicolor & heard onsite at several point count stations \\
\hline MAWR & marsh wren & Cistothorus palustris & males singing from cattails north of racetrack wetland \\
\hline CAWR & Carolina wren & Thyrothorus fudovicianus & abundant onsite \\
\hline EABL & eastern bluebird & Sialia sialis & several observed onsite \\
\hline GRCA & gray catbird & Dumetella carolinensis & forest edges \\
\hline NOMO & northern mockingbird & Mimus ployglottus & forest edges and fenceline along entry road \\
\hline CEDW & cedar waxwing & Bombycilla cedrorum & $\begin{array}{l}\text { several flyover groups observed/perched in CARWL along } \\
\text { RW }\end{array}$ \\
\hline EUST & european starling & Stumus vulgaris & several observed onsite \\
\hline NAWA & Nashville warbler & Oreothlypis ruficapilla & heard / observed onsite (1) \\
\hline NOPA & northern parula & Setophaga americana & heard / observed onsite (2) \\
\hline YWAR & yellow warbler & Setophago petechia & heard / observed onsite (3-5) \\
\hline PAWA & palm warbler & Setophaga polmarum & several observed onsite (2) \\
\hline COYE & common yellowthroat & Geothlypis trichas & abundant onsite \\
\hline $\begin{array}{l}\text { Warbler } \\
\text { spp. }\end{array}$ & Warbler species & & unidentified warbler species heard onsite \\
\hline INBU & indigo bunting & Passerino cyonea & heard onsite at several point count stations \\
\hline NOCA & northern cardinal & Cardinalis cordinalis & abundant onsite \\
\hline EATO & eastern towhee & Pipilo erythrothalmus & heard onsite \\
\hline BASP & Bachman's sparrow & Aimophila destevalis & heard onsite \\
\hline SOSP & song sparrow & Melospiza melodia & along road in reclamation area \\
\hline SWSP & swamp sparrow & Melospiza georgiona & heard onsite at several point count stations \\
\hline SAVS & savannah sparrow & Passerculus sandwichensis & observed along path northeast of coolong pond \\
\hline EAME & eastern meadowlark & Sturnella magna & territorial behavior on reclamation site \\
\hline RWBL & red-winged blackbird & Ageloius phoeniceus & abundant onsite \\
\hline COGR & common grackle & Quiscalus quiscula & abundant onsite \\
\hline BTGR & boat-tailed grackle & Quiscolus major & abundant onsite \\
\hline $\mathrm{BHCO}$ & brown-headed cowbird & Molothrus ater & abundant onsite \\
\hline
\end{tabular}


WETLAND NATURAL RESOURCES INVENTORY PHOTOS

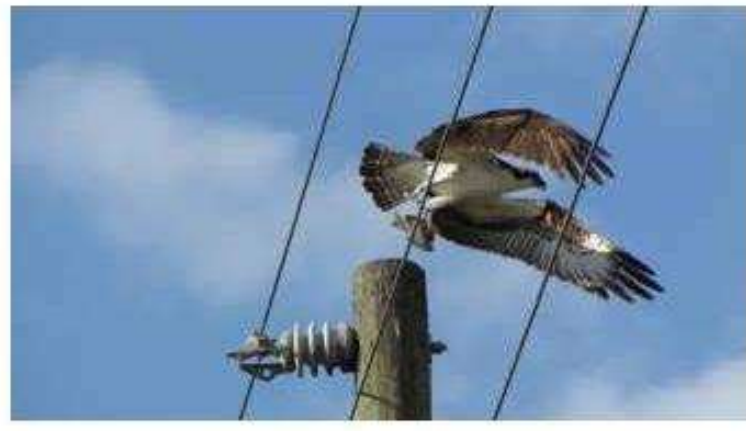

Osprey with fish

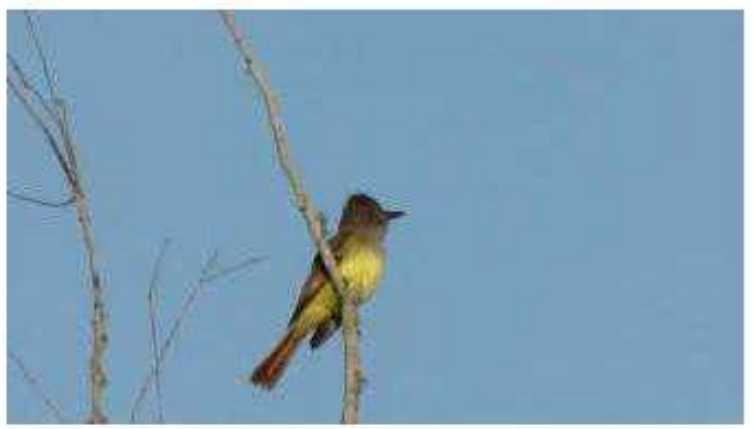

Great-crested flycatcher

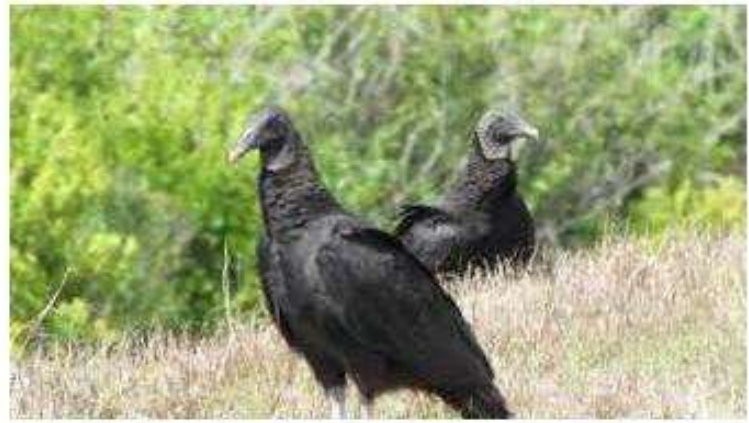

Black Vultures

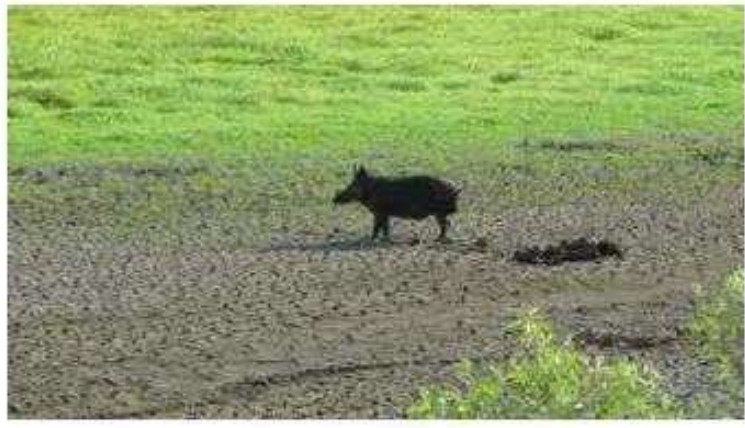

Feral Pig in SA-8 wetl and

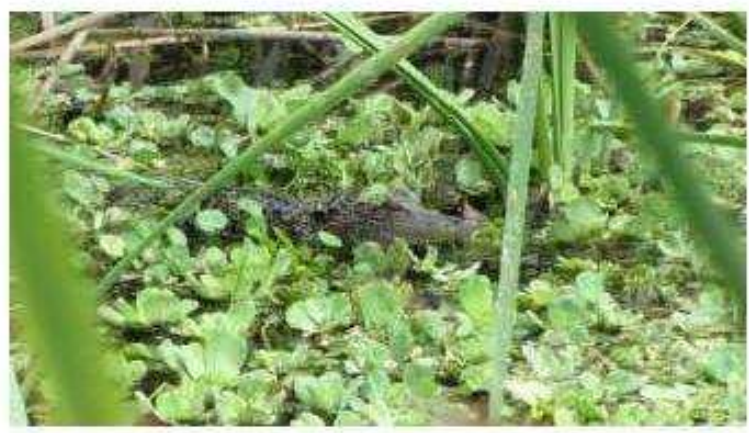

Young Ame rican Alligator basking

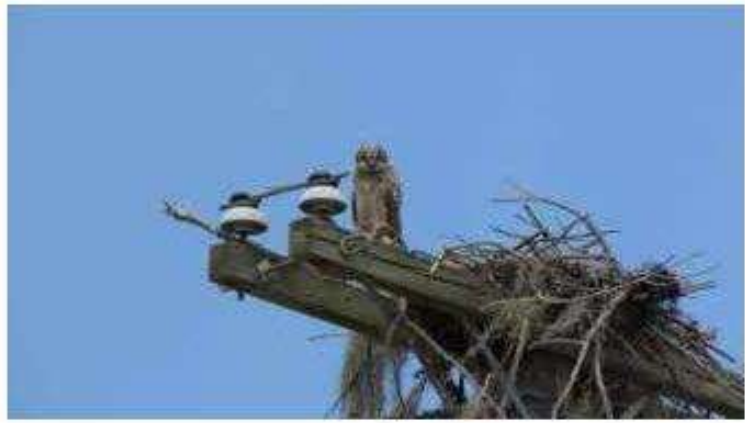

Gre at-homed Owl on nest 


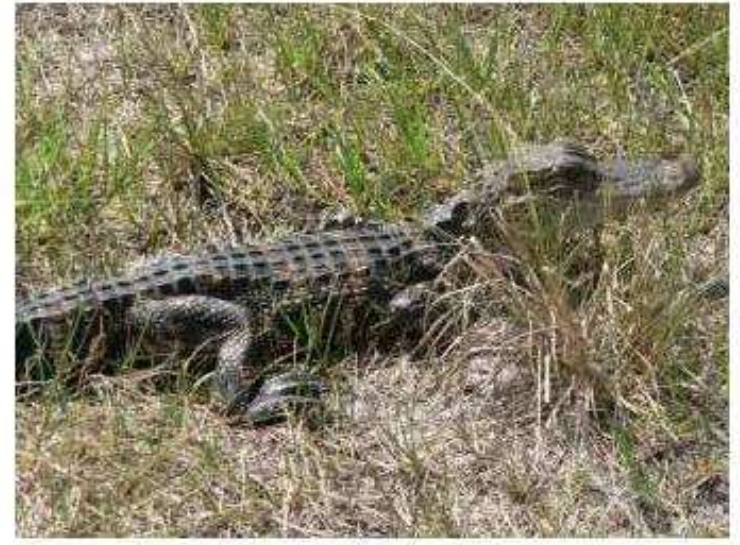

American Alligator juvenile

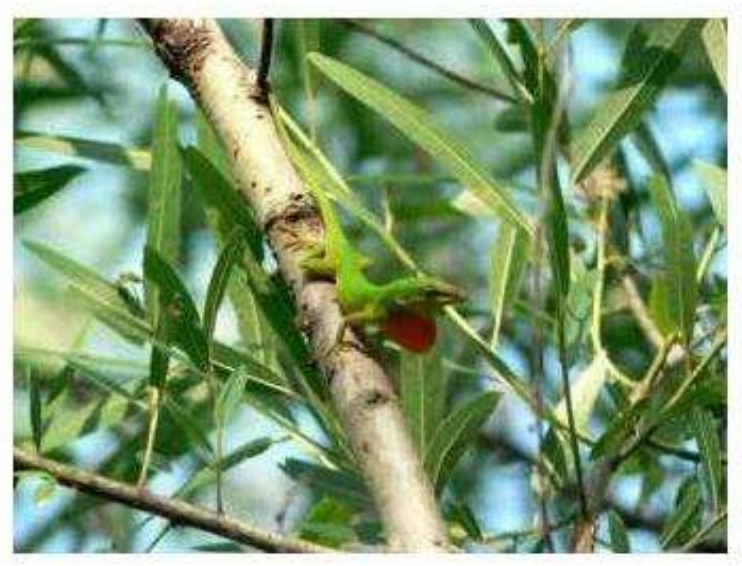

Green Anole

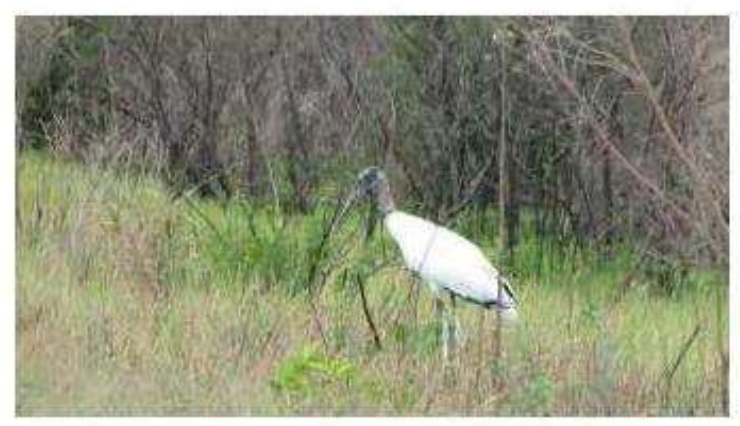

Wood Stork

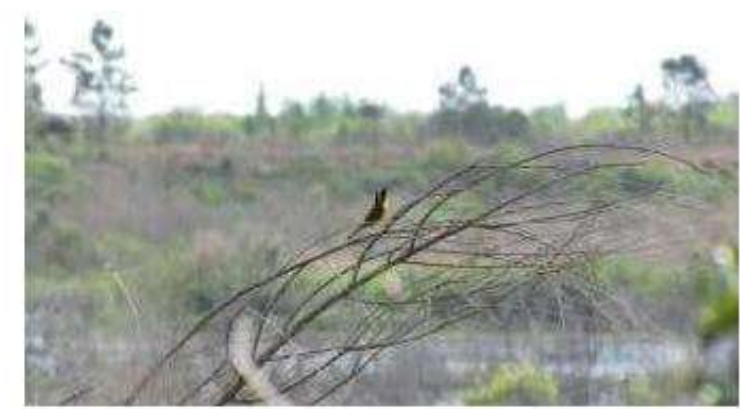

Common Yellowthroat

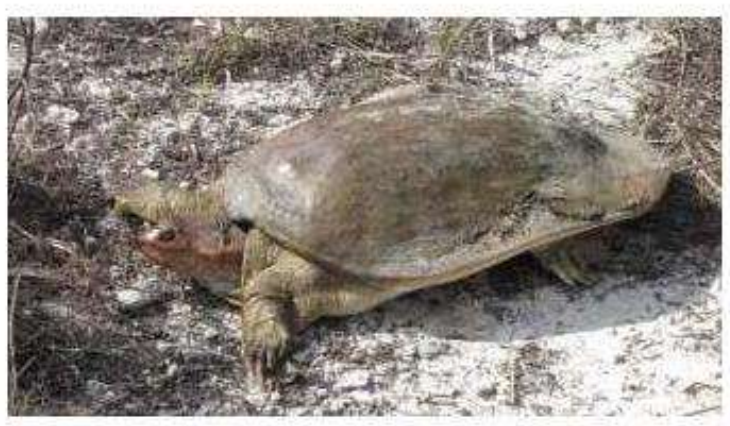

Florida Softshell Turtle

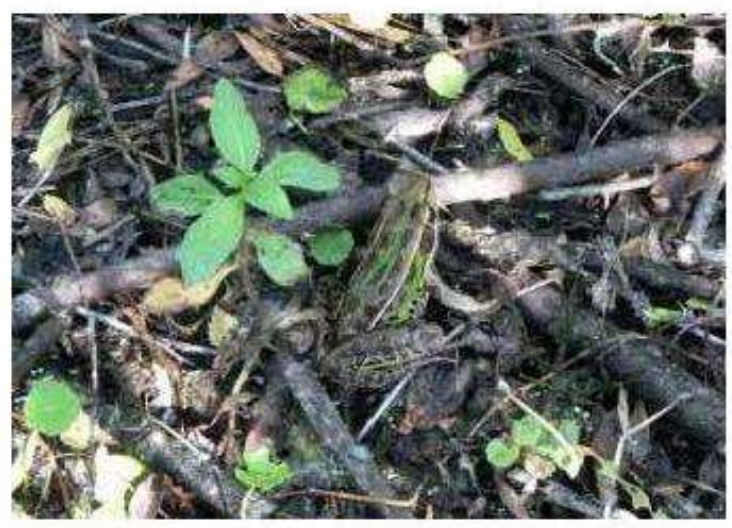

Southern Leopand Frog 


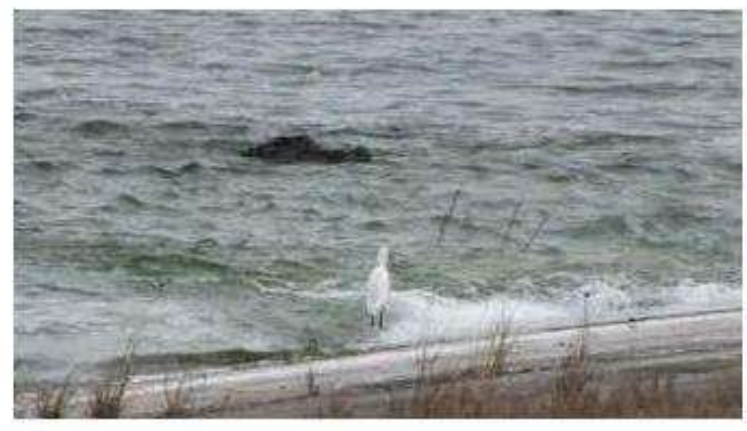

Egret and American Alligator

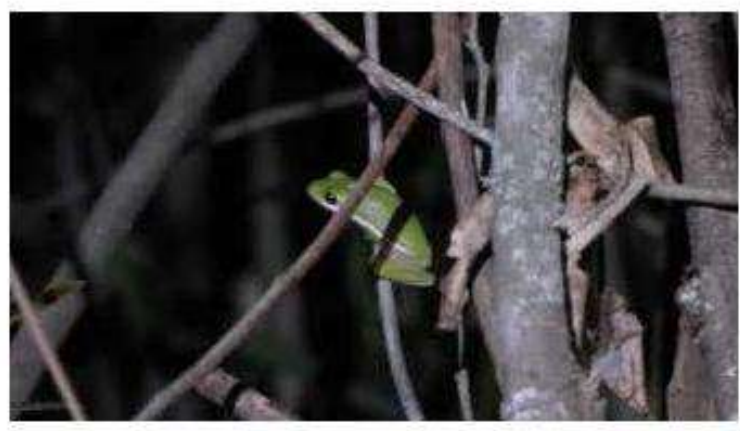

Green Treefrog

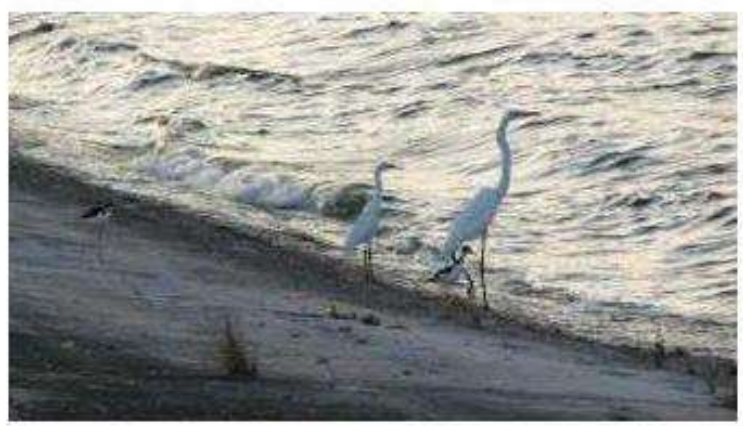

Gre at Egret, Snowy Egret and Black-necked Stilts

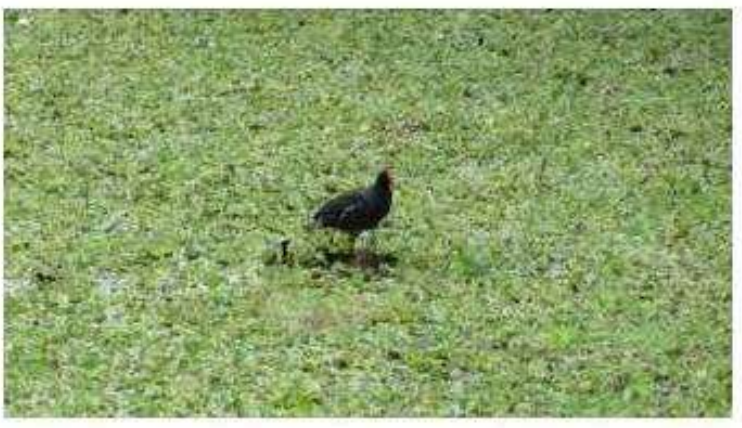

Common Moorhen

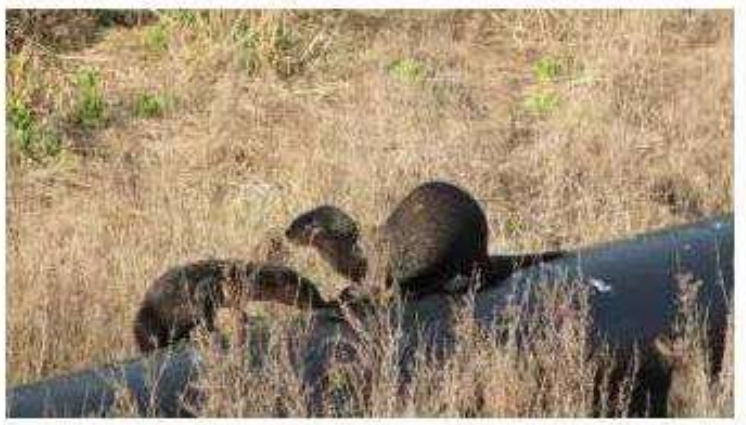

Northern River otter Family

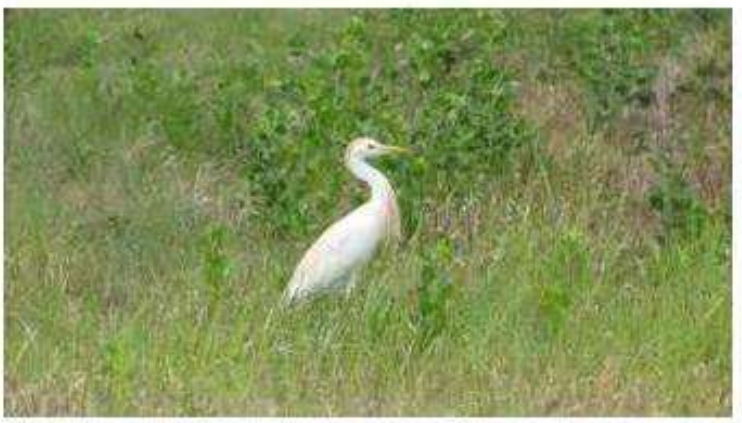

Cattle Egret 


\section{HINES ENERGY COMPLEX - SA-8 WETLAND CONSTRUCTION}

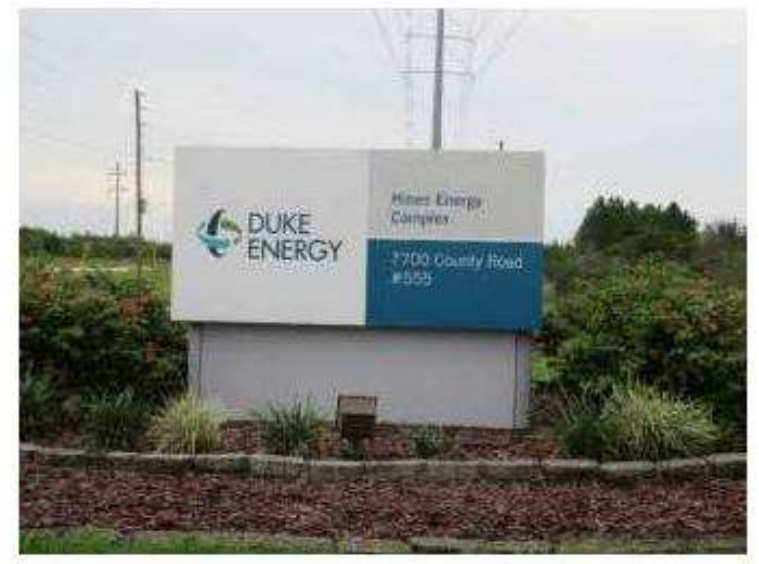

Hines Energy Complex, now owned by Duke Energy

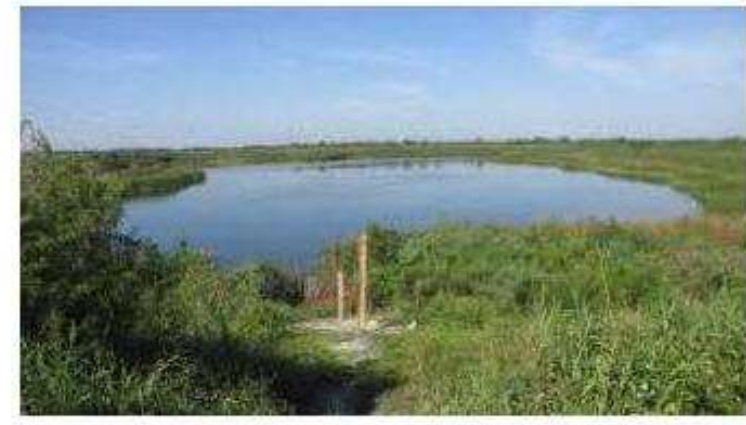

SA-8 Wetland Visit

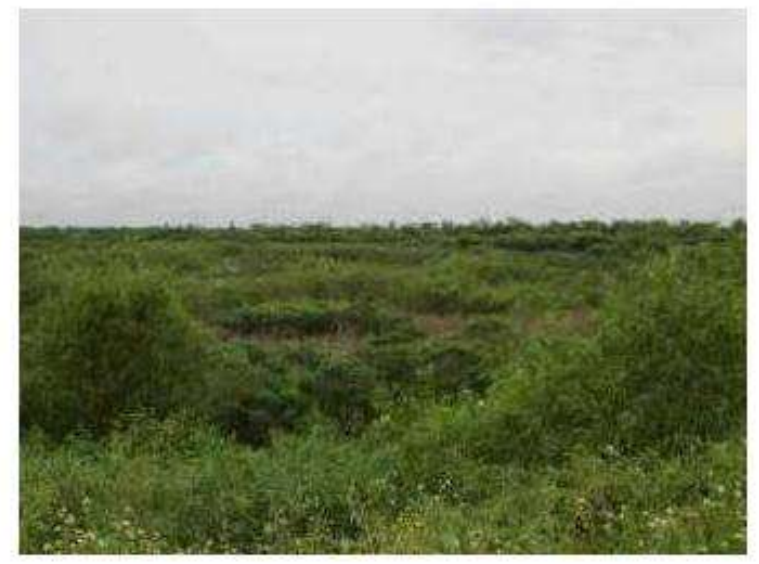

SA-8 Wetland Visit

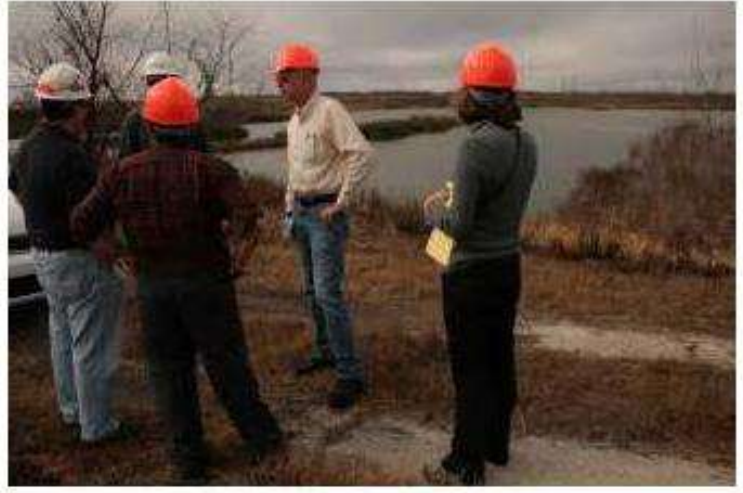

SA-8 Wetland Visit in 2011

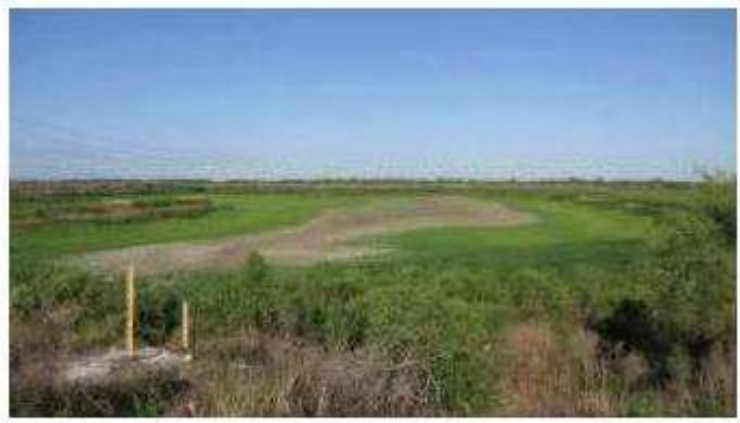

SA-8 Wetland Visit

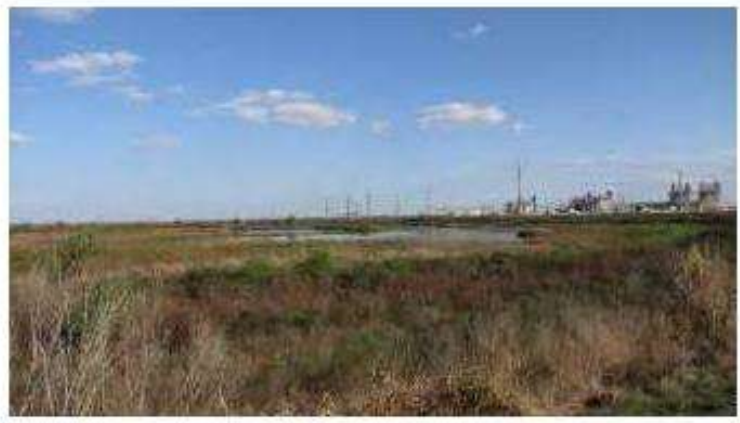

SA-8 Wetland Visit 


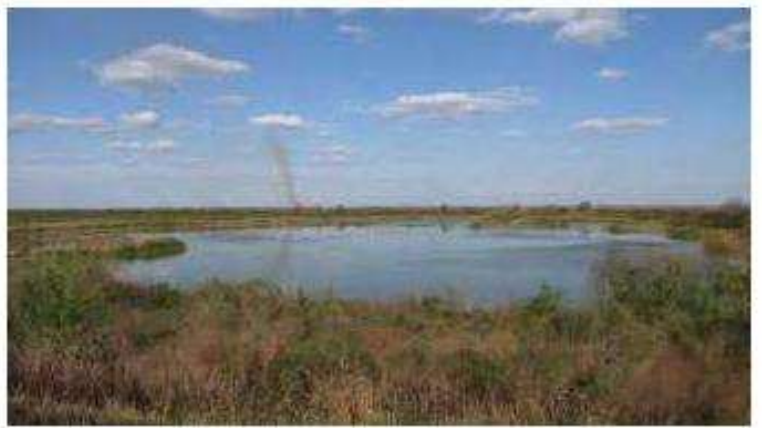

SA-8Wetland Visit

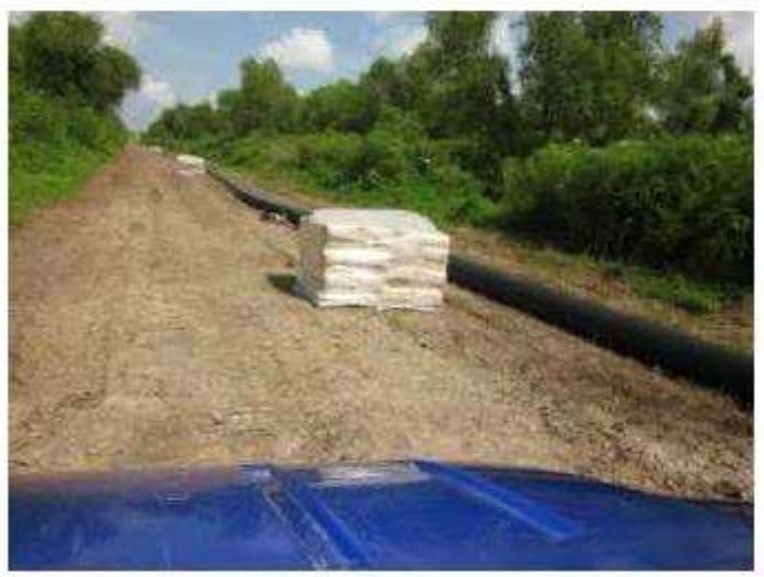

SA-8Wetland Construction Distribution He ader Valve

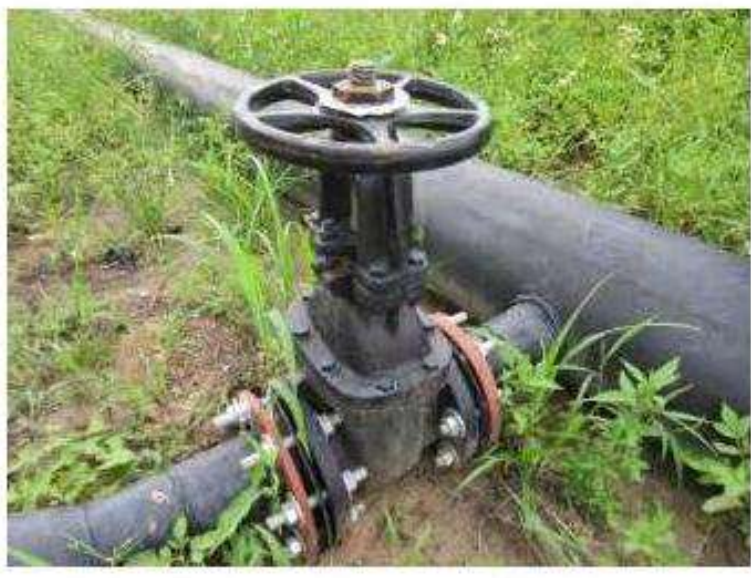

SA-8 Wetland Construction Distribution Header Valves

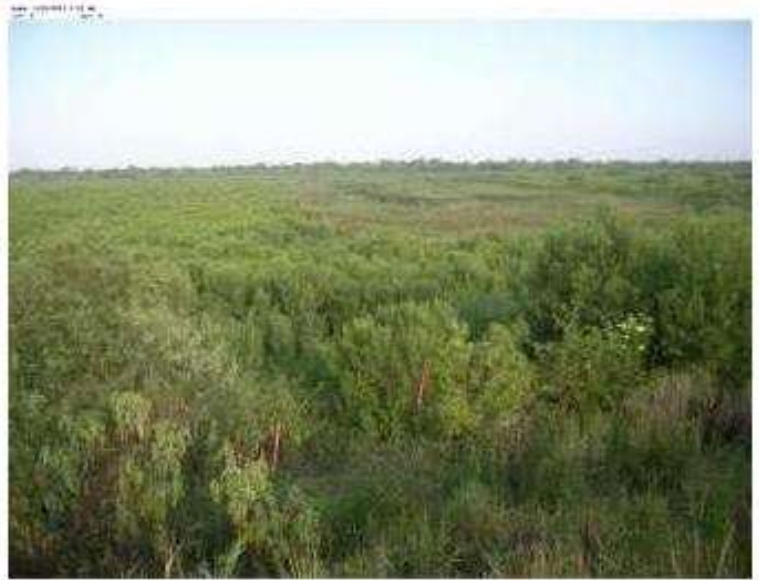

SA-8 Wetland Visit

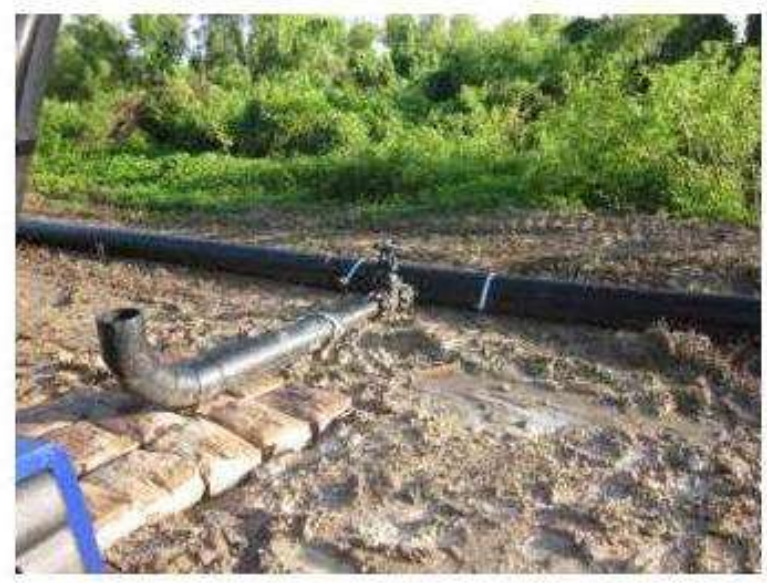

SA-8 Wetland Construction Distribution Header Valve / Outlet

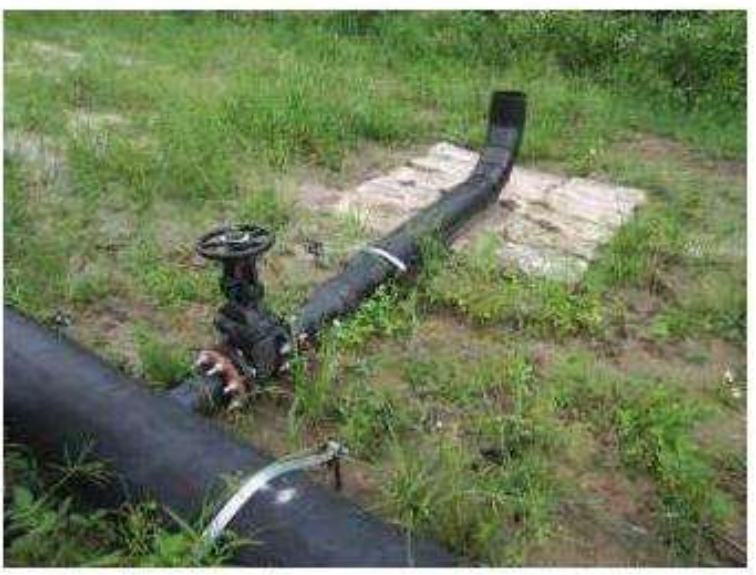

SA-8 Wetland Construction Distribution Header Valve / Outlet 


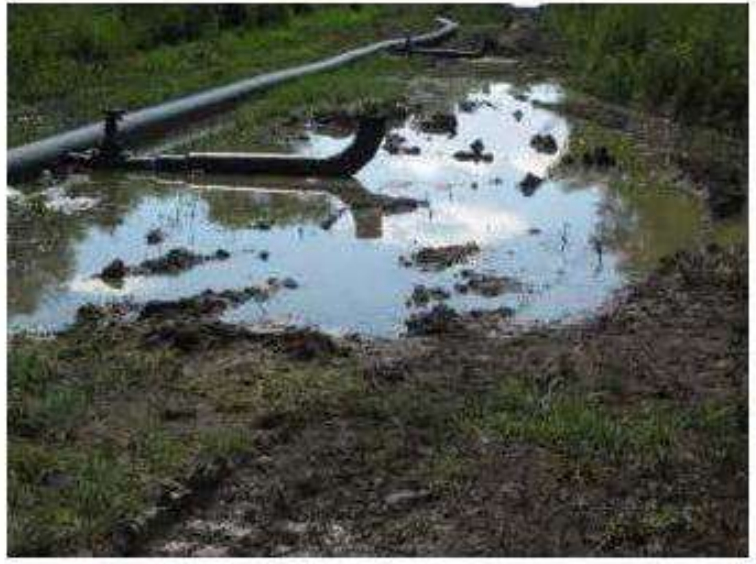

SA-8 Wetland Construction Distribution Header, with water

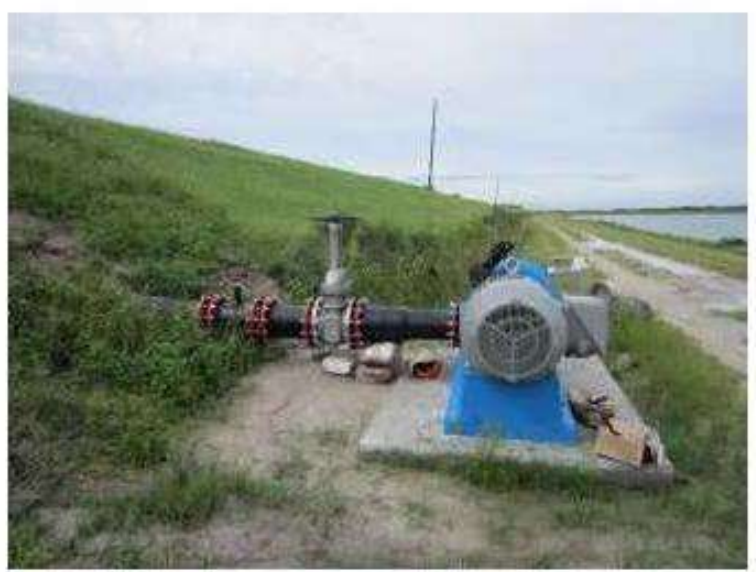

SA-8 Wetland Construction Inlet Pump

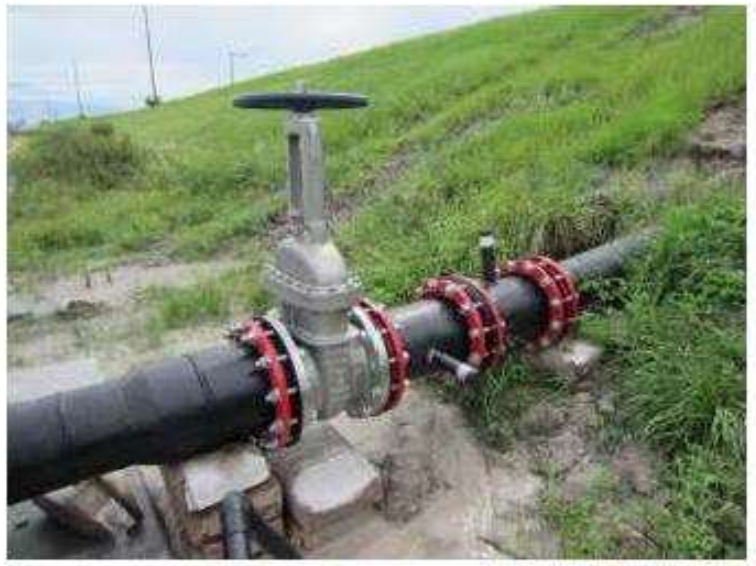

SA-8Wetland Construction Pipe taps for in-pipe monitoring

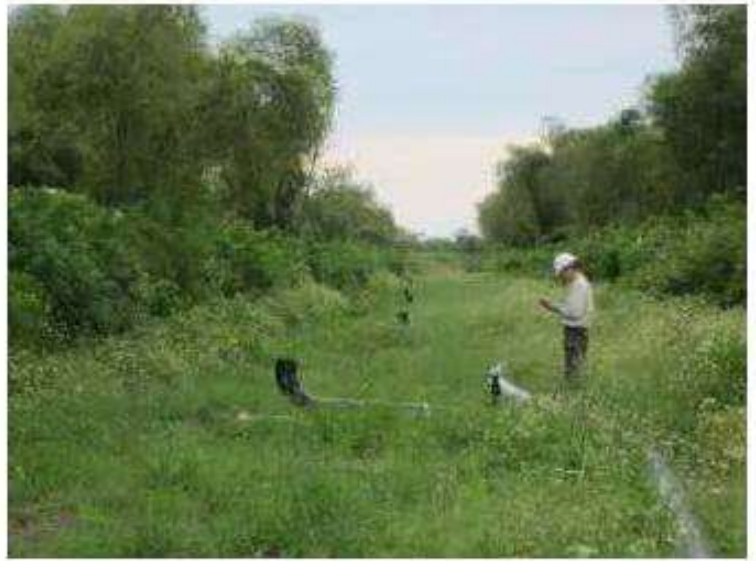

SA-8 Wetland Construction Distribution He ader, hum an scale

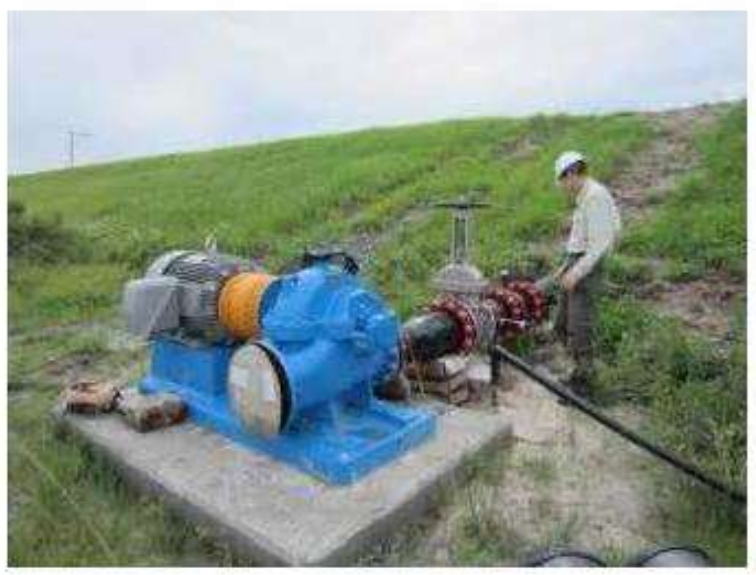

SA-8 Wetland Construction Inlet Pump from Upper Road

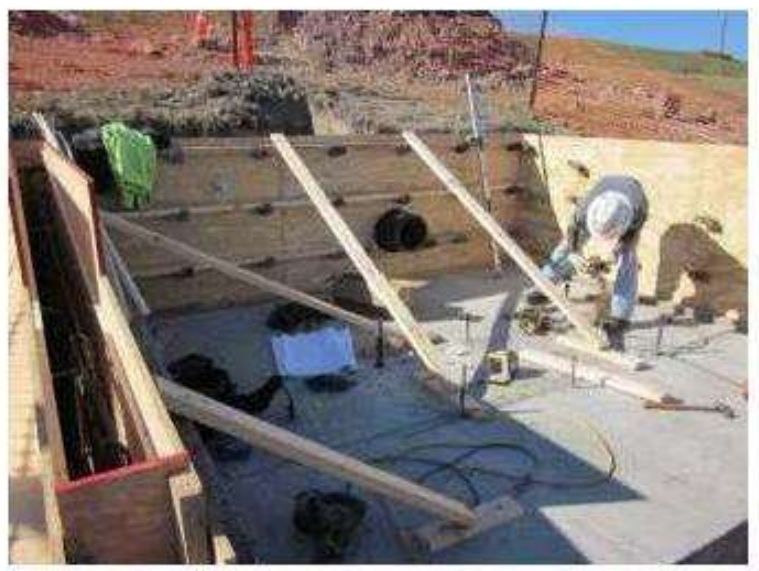

SA-8 Wetland Construction New Pump Location 


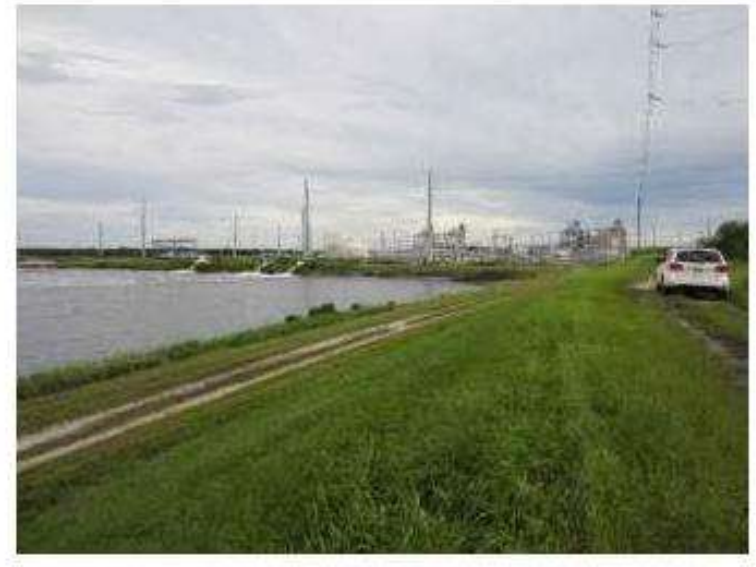

Duke Energy's Hines Energy Complex from outlet

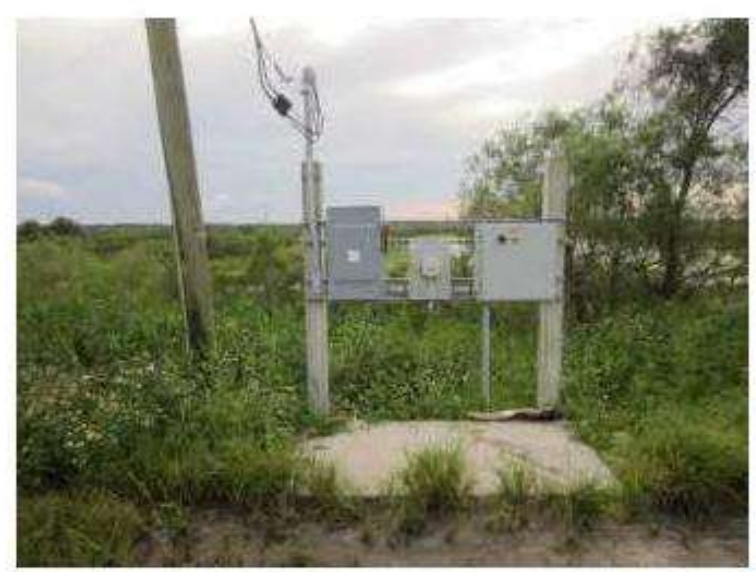

Electrical system for Outlet pump

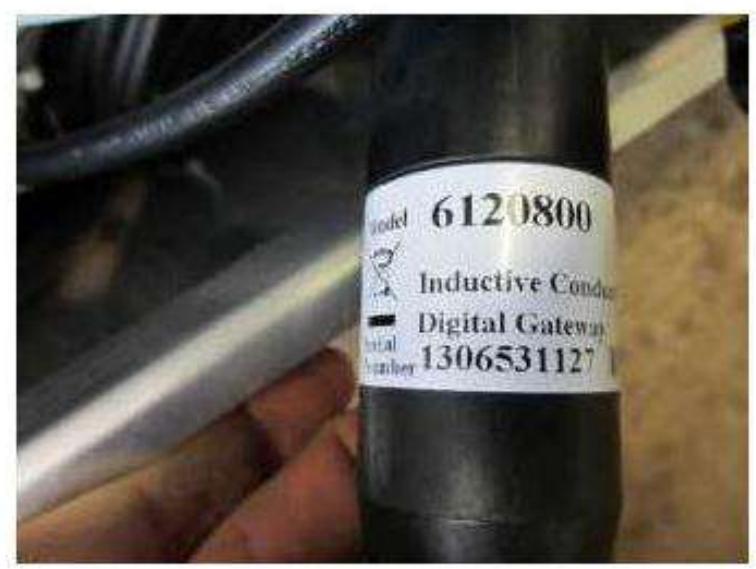

Hach Inductive Conductivity monitoring instrument

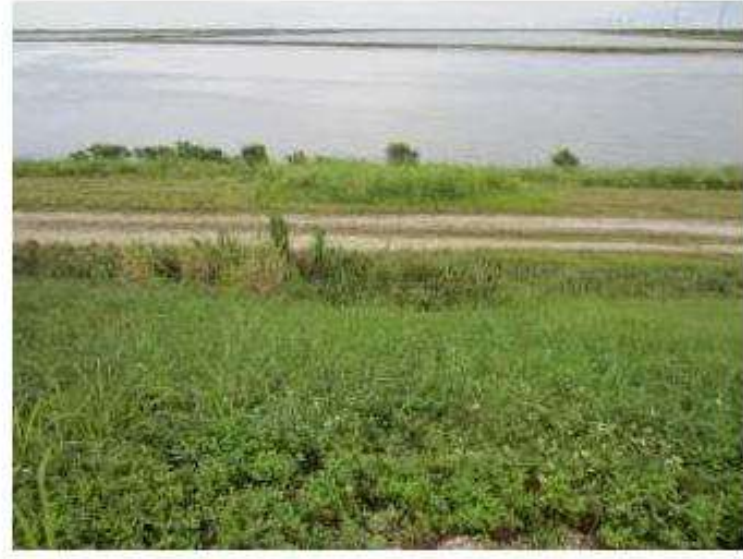

Outlet piping path from SA-8 to cooling pond

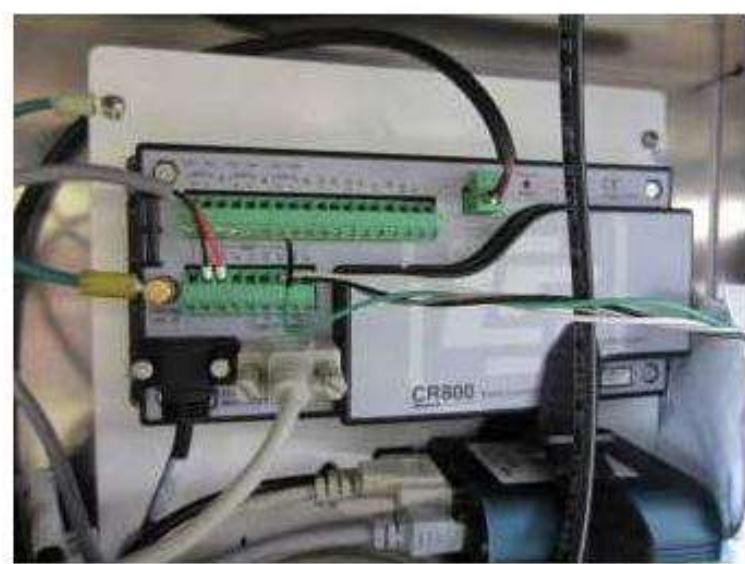

Campbell Scientific CR800 Datalogger

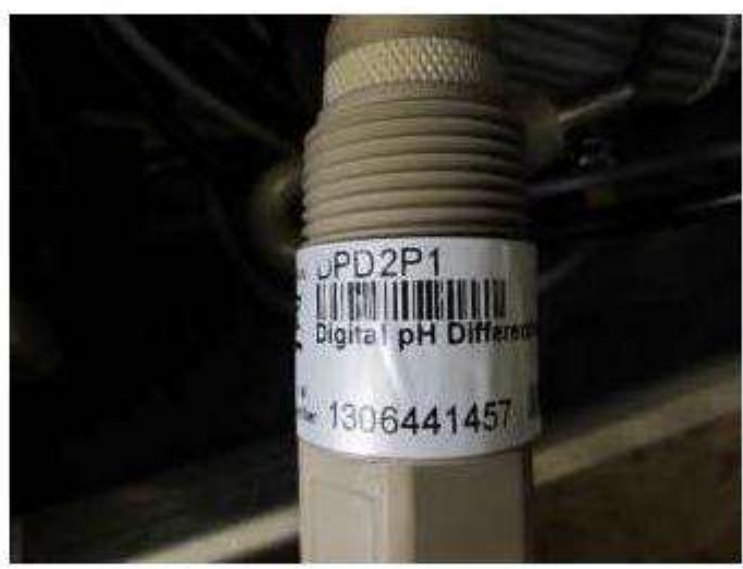

Hach $\mathrm{pH}$ and temperature monitoring instrument 


\section{Chapter 7 - Findings and Conclusions Stakeholder Database Listing}

\begin{tabular}{|c|c|c|c|c|c|c|c|c|c|}
\hline Company & First Name & Last Name & Job Title & E-mail Address & Business Phone & Address & City & State/Prov & Zip Code \\
\hline World Wildlife Fund & Jason & Clay & $\begin{array}{l}\text { Senior Vice President Market } \\
\text { Transformation }\end{array}$ & jason.clay@wwfus.org & $202-495-4691$ & 1250 24th Street NW & Washington & DC & 20037 \\
\hline National Audubon Society & Philip & Kavits & $\begin{array}{l}\text { Vice President, Chief } \\
\text { Communications \& Marketing }\end{array}$ & & $202-861-2242$ & $\begin{array}{l}1150 \text { Connecticut Avenue, NW } \\
\text { Suite } 600\end{array}$ & Washington & DC & 20036 \\
\hline The Nature Conservancy & & & Worldwide Office & & $800-628-6860$ & $\begin{array}{l}4245 \text { North Fairfax Drive } \\
\text { Suite } 100\end{array}$ & Arlington & VA & 22203 \\
\hline National Sierra Club & & & Legislative Office & & 202-547-1141 & 85 Second Street & Washington & DC & 20002 \\
\hline Natural Resources Defense Council & Ashok & Gupta & Air \& Energy Program Director & jpowers@nrdc.org & $212-727-2700$ & 40 West 20th Street & New York & NY & 10011 \\
\hline Electric Power Research Institute, Inc. & Bryan & Hannegan & $\begin{array}{l}\text { Vice President, Environment \& } \\
\text { Generation }\end{array}$ & & $202-872-9222$ & 2000 L Street NW & Washington & DC & 20036 \\
\hline Applied Ecological Services, Inc. & Steven & Apfelbaum & Chairman, Principal Ecologist & Steve@appliedeco.com & $608-897-8641$ & $\begin{array}{l}17921 \text { Smith Road } \\
\text { P.O. box } 256\end{array}$ & Brodhead & WI & 53520 \\
\hline Natural Resources Defense Council & Drew & Caputo & Wetlands Expert & loster@nrdc.org & $415-875-6100$ & $\begin{array}{l}111 \text { Sutter Street } \\
\text { 20th Floor }\end{array}$ & San Francisco & CA & 94104 \\
\hline Natural Resources Defense Council & Nancy & Stoner & Water Program Director & moko@nrdc.org & 202-289-6868 & $\begin{array}{l}1200 \text { New York Avenue, NW } \\
\text { Suite } 400\end{array}$ & Washington & $\mathrm{DC}$ & 20005 \\
\hline Water Environment Federation & Matt & Jones & Technical \& Educational Services & mjones@wef.org & $1-800-666-0206$ & 601 Wythe Street & Alexandria & VA & $\begin{array}{l}22314- \\
1994\end{array}$ \\
\hline WateReuse Association & Anna & Durden & Project Manager & adurden@watereuse.org & 703-548-0880 & $\begin{array}{l}1199 \text { North Fairfax Street } \\
\text { Suite } 410\end{array}$ & Alexandria & VA & 22314 \\
\hline National Association of Clean Water Agencies & Ken & Kirk & Executive Director & kkirk@nacwa.org & 202-833-4653 & 1816 Jefferson Place N.W. & Washington & $\mathrm{DC}$ & 20036 \\
\hline $\begin{array}{l}\text { Association of State and Interstate Water } \\
\text { Pollution Control Administrators }\end{array}$ & Tom & Porta & President & & $202-756-0600$ & $\begin{array}{l}1221 \text { Connecticut Avenue N.W. } \\
\text { 2nd Floor }\end{array}$ & & DC & 20036 \\
\hline Edison Electric Institute (EEI) & Quinlan J. & Shea, IIII & Executive Director, Environment & environment@eei.org & $202-508-5000$ & 701 Pennsylvania Avenue, N.W. & & DC & 20004 \\
\hline Alabama Electric Coop Inc & & & & & $334-427-3000$ & 2027 East Three Notch St. & Andalusia & AL & 36420 \\
\hline Alabama Power Co & & & & & $800-245-2244$ & P.O. Box 2641 & Birmingham & AL & 35291 \\
\hline Rock-Tenn Company & James & Rubright & Chief Executive Officer & & $770-448-2193$ & 504 Thrasher Street & Norcross & GA & 30071 \\
\hline Tennessee Valley Authority & Tom & Kilgore & Executive Officer & tvainfo@tva.gov & 865-632-2101 & 400 W. Summit Hill Dr. & Knoxville & AL & 37902 \\
\hline Weyerhaeuser Co & Heidi & Biggs-Brock & VP Federal and International Affairs & & 253-924-2345 & PO Box 9777 & Federal Way & WA & 98063 \\
\hline City of Lakeland & Jim & Studiale & Community Development Director & Jim.Studiale@lakelandgov.net & 863-834-6011 & 228 South Massachusetts Ave & Lakeland & $\mathrm{FL}$ & 33801 \\
\hline Gainesville Regional Utilities & & & & & $352-393-1460$ & 301 SE 4th Avenue & Gainesville & $\mathrm{FL}$ & 32601 \\
\hline Gulf Power Co & & & & & $800-225-5797$ & One Energy Place & Pensacola & FL & 32520 \\
\hline JEA & Athena & Mann & VP Environmental Services & & $904-665-6000$ & 21 West Church Street & Jacksonville & FL & 32202 \\
\hline Jefferson Smurfit Corp & & & & & $314-656-5300$ & Six City Place Drive & Creve Coeur & mo & 63141 \\
\hline Orlando Utilities Comm & & & & & $407-423-9100$ & 3800 Gardenia Ave & Orlando & FL & \\
\hline Progress Energy Florida Inc & & & & & & & & $\mathrm{FL}$ & \\
\hline Seminole Electric Coop, Inc & Timothy & Woodbury & VP and General Manager & & 813-963-0994 & $\begin{array}{l}16313 \text { North Dale Mabry Hwy. } \\
33618\end{array}$ & Tampa & FL & 33688 \\
\hline Tampa Electric Co & Thomas & Hernanzez & VP Energy Delivery & & 888-223-0800 & PO Box 31318 & Tampa & $\mathrm{FL}$ & 33631 \\
\hline Georgia Pacific LLC & Bostic & James & VP Environmental & & $404-652-4000$ & 133 Peachtree St. & Atlanta & GA & 30303 \\
\hline Georgia Power Co & & & & & 404-506-6526 & 241 Ralph McGill Boulevard NE & Atlanta & FL & 30308 \\
\hline SP Newsprint Company & & & & & 904-354-1669 & 1580 West Beaver Street & Jacksonville & $\mathrm{FL}$ & 32209 \\
\hline Boise Packaging \& Newsprint LLC & & & & & 208-384-6161 & P.O. Box 990050 & Boise & ID & 83799 \\
\hline Louisiana Generating LLC & Meredith & Moore & Sr. Vice President-Communications & & $609-524-4522$ & 211 Carnegie Center & Princeton & NJ & 08540 \\
\hline
\end{tabular}




\begin{tabular}{|c|c|c|c|c|c|c|c|c|c|}
\hline Company & First Name & Last Name & Job Title & E-mail Address & Business Phone & Address & City & State/Prov & Zip Code \\
\hline Temple-Inland Corp & Doyle & Simons & & & $512-434-5800$ & 1300 S Mopac Expy FL 3 & Austin & $\mathrm{TX}$ & 78746 \\
\hline Choctaw Generation LP & & & & & $713-599-2603$ & 1177 West Loop South & Houston & $T X$ & 77027 \\
\hline Blue Ridge Paper Products Inc & & & & & $866-575-4250$ & & Canton & NC & \\
\hline Carlyle/Riverstone Renewable Energy & & & & & $704-632-0200$ & 128 South Tryon Street & Charlotte & NC & 28202 \\
\hline Domtar Paper Company LLC & Guy & Boucher & $\begin{array}{l}\text { Vice President, Sustainable } \\
\text { Development }\end{array}$ & & $514-848-5176$ & 395 de Maisonneuve Blvd. West & Montreal & $\begin{array}{l}\text { Quebec } \\
\text { Canada }\end{array}$ & \\
\hline Duke Energy Carolinas, LLC & & & & & $800-777-9898$ & $\begin{array}{l}526 \text { South Church St, P.O. Box } \\
70516\end{array}$ & Charlotte & NC & 28272 \\
\hline North Carolina Power Holdings, LLC & & & & & $910-392-7690$ & 3212 Wickford Dr. & Wilmington & NC & 28409 \\
\hline Primary Energy of North Carolina LLC & & & & & $910-457-5056$ & 1281 Powerhouse $\mathrm{Dr}$ & Southport & NC & 28461 \\
\hline South Carolina Electric \& Gas Co & & & & & $800-251-7234$ & PO Box 100255 & Columbia & sc & 29202 \\
\hline Mirant Potomac River LLC & Chuck & Oliver & Plant Manager & $\begin{array}{l}\text { community.outreach@mirant. } \\
\text { com }\end{array}$ & & 1400 North Royal Street & Alexandria & VA & 22314 \\
\hline Southeastern Public Serv Auth & Rowland & Taylor & Executive Director & & $757-420-4700$ & 723 Woodlake Drive & Chesapeake & VA & 23320 \\
\hline Minnesota Municipal Power Agency & Derick & Dahlen & Executive Manager & & $612-349-6868$ & $\begin{array}{l}200 \text { S. 6th St. } \\
\text { Suite } 300\end{array}$ & Minneapolis & $\mathrm{MN}$ & 55402 \\
\hline $\begin{array}{l}\text { South Florida Ecosystem Restoration Task } \\
\text { Force }\end{array}$ & & & The Office of the Executive Director & & 305-348-1665 & $\begin{array}{l}\text { c/o Florida International Univ } \\
11200 \text { SW 8th Street } \\
\text { OE } 165\end{array}$ & Miami & FL & 33199 \\
\hline lowa Natural Heritage Foundation & Mark & Ackelson & President & mackelson@inhf.org & $515-288-1846$ & $\begin{array}{l}505 \text { Fifth Ave. } \\
\text { Suite } 444\end{array}$ & Des Moines & IA & 50309 \\
\hline Alaska Division of Water & William & Ashton & Wetlands Coordinator & william.ashton@alaska.gov & $907-269-6283$ & 555 Cordova Street & Anchorage & AK & 99501 \\
\hline Arkansas Multi-Agency Wetland Planning Team & Jennifer & Sheehan & Coordination Office & jesheehan@agfc.state.ar.us & $501-223-6356$ & \#2 Natural Resources Dr. & Little Rock & AR & 72205 \\
\hline Riparian Habitat Joint Venture & Scott & Clemons & & Sclemons@dfg.ca.gov & $916-445-1072$ & & & CA & \\
\hline San Francisco Bay Joint Venture & Beth & Huning & SFBJV Coordinator & bhuning@sfbayjv.org & 415-259-0334 & 735 B Center Blvd. & Fairfax & CA & 94930 \\
\hline California Department of Parks and Recreation & John & Arnold & & jarno@parks.ca.gov & $916-653-7090$ & P.O. Box 942896 & Sacramento & CA & 94296 \\
\hline South Florida Water Management District & Carol Ann & Wehle & Executive Director & cwehle@sfwmd.gov & 561-682-2893 & P.O. Box 24680 & $\begin{array}{l}\text { West Palm } \\
\text { Beach }\end{array}$ & FL & 33416 \\
\hline Ameren Corp & Susan & Gallagher & & sgallagher@ameren.com & $314-554-2175$ & & & & \\
\hline Kansas City Power and Light Company & & & & & $816-556-2200$ & P.O. Box 418679 & Kansas City & Mo & 64121 \\
\hline Minnkota Power Cooperative, Inc. & $\mathrm{Al}$ & Tschepen & $\begin{array}{l}\text { Vice President-Planning \& System } \\
\text { Operations }\end{array}$ & atschepen@minnkota.com & $701-795-4000$ & 1822 Mill Road & Grand Forks & ND & 58208 \\
\hline Nebraska Public Power District & & & & & $402-564-8561$ & 1414 15th Street & Columbus & NE & 68602 \\
\hline Xcel Energy & & & & & $1-800-328-8226$ & 414 Nicollet Mall & Minneapolis & MN & 55401 \\
\hline Southern Illinois Power Cooperative & & & & & 618-964-1448 & 11543 Lake of Egypt Road & Marion & IL & 62959 \\
\hline City Water, Light, and Power & Todd & Renfrow & General Manager & & 217-789-2116 & $\begin{array}{l}\text { Municipal Center East } \\
800 \text { E. Monroe St. }\end{array}$ & Springfield & IL & 62757 \\
\hline Exelon Energy & Paul & Weeks & Peaking Division General Manager & & $800-483-3220$ & $\begin{array}{l}\text { 10 S. Dearborn Street, 48th } \\
\text { Floor }\end{array}$ & Chicago & IL & 60608 \\
\hline Southwestern Electric Power Co & & & & & $318-862-2000$ & 6300 Line Ave & Shreveport & LA & 71106 \\
\hline AEP Texas North Co & Michael & Morris & Chairman, President, and CEO & & 877-373-4858 & 301 Cypress Street & Abilene & $\mathrm{TX}$ & \\
\hline Bryan City of & Eric & Zaragoza & Interim Operations Manager & ezaragoza@bryantx.gov & 979-209-5900 & 1111 Waco Street & Bryan & $T X$ & 77803 \\
\hline Progress Energy Carolinas Inc & Jeff & Corbett & Sr. Vice President-Energy Delivery & & $919-508-5400$ & PO Box 1551 & Raleigh & NC & 27602 \\
\hline Cleco Power LLC & Michael & Madison & President/Chief Executive & & $318-484-7400$ & 2030 Donahue Ferry Rd & Pineville & LA & 71361 \\
\hline Topaz Power Group LLC & Darren & Stephens & President & & $512-314-8600$ & 2705 Bee Caves Road, Suite 340 & Austin & $\mathrm{TX}$ & 78746 \\
\hline Central Power \& Lime Inc & & & & & $352-799-7881$ & 10311 Cement Plant Rd & Brooksville & FL & 34601 \\
\hline Detroit Edison Co (DTE Engergy Services) & & & & & $800-477-4747$ & One Energy Plaza & Detroit & MI & 48226 \\
\hline
\end{tabular}




\begin{tabular}{|c|c|c|c|c|c|c|c|c|c|}
\hline Company & First Name & Last Name & Job Title & E-mail Address & Business Phone & Address & City & State/Prov & Zip Code \\
\hline Dynegy Midwest Generation Inc & Norelle & Lundy & VP-Public Relations & & $713-507-6400$ & $\begin{array}{l}1000 \text { Louisiana Street, Suite } \\
5800\end{array}$ & Decatur & IL & 77002 \\
\hline Entergy Inc & Michael & Barnhill & Director of Economic Development & tbarnhi@entergy.com & 800-368-3749 & 9425 Pinecroft & $\begin{array}{l}\text { The } \\
\text { Woodlands }\end{array}$ & $T X$ & 77380 \\
\hline Lower Colorado River Authority & & & & waterconservation@|cra.org & $800-776-5272$ & 3700 Lake Austin Blvd & Austin & $T X$ & 78703 \\
\hline Midwest Generations EME LLC & & & & & $312-583-6000$ & 440 S. LaSalle St \#3500 & Chicago & IL & 60605 \\
\hline Mississippi Power Co & & & & & 866-251-1943 & 2992 West Beach Blvd & Gulfport & MS & 39501 \\
\hline Oklahoma Gas \& Electric Co & John & Wendling & VP Power Supply & & 800-272-9741 & PO Box 321 & $\begin{array}{l}\text { Oklahoma } \\
\text { City }\end{array}$ & ок & 73101 \\
\hline Otter Tail Power Co & Todd & Wahlund & VP Renewable Energy & & $218-739-8297$ & 215 S. Cascade Street & Fergus Stone & MN & 56538 \\
\hline Portland General Electric Co & Jalsen & Mody & Director & & $503-464-8000$ & $121 \mathrm{SW}$ Salmon Street & Portland & $O R$ & 97204 \\
\hline Public Service Co of Colorado & Keith & Carman & & Carman@xcelenergy.com & $303-278-4758$ & PO Box 1078 & Golden & $\mathrm{CO}$ & 80402 \\
\hline PSI Energy Inc & & & & & $317-839-9611$ & 1000 East Main Street & Plainfield & IN & 46168 \\
\hline Public Service Co of Oklahoma & & & & & $888-216-3523$ & PO Box 201 & Tulsa & OK & 74102 \\
\hline Sierra Pacific Power Co & & & & & $775-834-4011$ & 6100 Neil Rd & Reno & NV & 89511 \\
\hline Midland Cogeneration Venture & Rodney & Boulanger & President/CEO & & $989-839-6000$ & 100 Progress Place & Midland & MI & 48640 \\
\hline Texas Municipal Power Agency & Jan & Horbaczewski & $\begin{array}{l}\text { Mine, Land, and Environmental } \\
\text { Manager }\end{array}$ & & $936-873-1100$ & Texas Municipal Power Agency & Bryan & $T X$ & 77805 \\
\hline Alcoa Inc & & & & & $412-553-4545$ & 201 Isabella St & Pittsburgh & PA & 15212 \\
\hline Arizona Public Service Co & & & & & $602-250-1000$ & PO Box 2906 & Phoenix & $\mathrm{AZ}$ & 85062 \\
\hline Dominion Energy Services Co & & & & & 217-237-4311 & & Kincaid & IL & 62540 \\
\hline Empire District Electric Co & & & & & $800-206-2300$ & $\begin{array}{l}602 \text { S Joplin Avenue, P.O. Box } \\
127\end{array}$ & Joplin & мо & 64802 \\
\hline Hoosier Energy R E C Inc & Robert & Hochstetler & VP Power Production & & 812-878-2021 & 7398 North State Rd 37 & Bloomington & IN & 47404 \\
\hline Arkansas Electric Coop Corp & & & & & $501-570-2200$ & $\begin{array}{l}1 \text { Cooperative Way, P.O. Box } \\
194208\end{array}$ & Little Rock & $A R$ & 72219 \\
\hline Public Service Co of New Hampshire & Long & Gary & President \& Chief Operating Officer & psnhreq@psnh.com & $800-662-7764$ & PO Box 638 & Manchester & $\mathrm{NH}$ & 03105 \\
\hline South Carolina Pub Serv Auth & & & & & $843-761-8000$ & 1 Riverwood Dr. & $\begin{array}{l}\text { Moncks } \\
\text { Corner }\end{array}$ & sc & 29461 \\
\hline Springfield City of & Greg & Burris & City Manager & & $417-864-1000$ & 840 Boonville Ave. & Springfield & мо & 65802 \\
\hline Birchwood Power Partners LP & & & & & $614-807-5105$ & 10900 Birchwood Dr. & King George & VA & 22485 \\
\hline South Mississippi Electric Power Assn & $\operatorname{Jim}$ & Compton & General Manager/CEO & info@smepa.coop & $601-268-2083$ & 7037 US HWY 49 & Hattiesburg & MS & 39402 \\
\hline Ameren Energy Generating Co & Charles & Naslund & President & & $314-621-3222$ & 1901 Chouteau Ave & St Louis & мо & 63103 \\
\hline Lansing City of & Bob & Johnson & Director of Planning & & $517-483-4060$ & 316 N. Capitol Ave. & Lansing & MI & 48933 \\
\hline Platte River Power Authority & & & & energyservices@prpa.org & $970-226-4000$ & 2000 East horsetooth Rd & Fort Collins & $\mathrm{CO}$ & 80525 \\
\hline TXU Electric Co & Jim & Burke & Chief Executive Officer & jburke1@txu.com & & PO Box 650764 & Dallas & TX & 75262 \\
\hline International Paper Co & & & & & $901-419-9000$ & 6400 Poplar Ave. & Memphis & TN & 38197 \\
\hline Reliant Energy Etiwanda Inc & & & & & 713-207-7777 & 1000 Main Street & Houston & TX & 77002 \\
\hline the University of Illinois & к.C. & Ting & Professor and Department Head & & 217-333-1000 & 601 East John Street & Champaign & IL & 61820 \\
\hline Illinois State University & Angelo & Capparella & Head of Biological Sciences & & $309-438-5124$ & & Normal & IL & 61790 \\
\hline Southern Illinois University & Steven & Esling & $\begin{array}{l}\text { Professor/Chair-Environmental } \\
\text { Policy }\end{array}$ & esling@geo.siu.edu & $618-453-7376$ & & Carbondale & IL & 62901 \\
\hline Eastern IIlinois University & Mary Anne & Hanner & Dean-Sciences & mahanner@eiu.edu & $217-581-3126$ & 2118 Old Main & Charleston & IL & 61920 \\
\hline Northwestern University & Kimberly & Gray & $\begin{array}{l}\text { Professor/Department Head- } \\
\text { Environmental Sciences }\end{array}$ & k-gray@northwestern.edu & $847-467-4252$ & 633 Clark Street & Evanston & IL & 60208 \\
\hline Northern Illinois University & Carl & Ende & Ecology & t80cnv1@wpo.cso.niu.edu & $815-753-7826$ & & Dekalb & IL & 60115 \\
\hline
\end{tabular}




\begin{tabular}{|c|c|c|c|c|c|c|c|c|c|}
\hline Company & First Name & Last Name & Job Title & E-mail Address & Business Phone & Address & City & State/Prov & Zip Code \\
\hline Florida State University & Amy & Chan & $\begin{array}{l}\text { Professor of Environmental } \\
\text { Engineering }\end{array}$ & abchan@eng.fsu.edu & $850-410-6121$ & $600 \mathrm{~W}$. College & Tallahassee & FL & 32306 \\
\hline University of Florida & & & & http://www.cals.ufl.edu/ & $352-392-1963$ & 2002 McCarty Hall Dr. & Gainsville & FL & 32611 \\
\hline Florida A \& M & & & & & $850-599-3000$ & 1700 Lee Hall Dr. & Tallahassee & FL & 32307 \\
\hline Florida Atlantic University & & & & & $561-297-3000$ & 777 Glades Road & Baco Raton & $\mathrm{FL}$ & 33431 \\
\hline Indiana University & & & & & $812-855-4848$ & 107 S. Indiana Ave & Bloomington & IN & 47405 \\
\hline Notre Dame University & Lodge & David & Professor of Biological Sciences & biology@nd.edu & $574-631-6552$ & 100 Galvin Life Sciences Center & Notre Dame & IN & 46556 \\
\hline Indiana State University & George & Bakken & Professor & George.Bakken@indstate.edu & 812-237-2396 & 200 North Seventh St. & Terre Haute & IN & 47809 \\
\hline Ball State University & Paul & Chandler & $\begin{array}{l}\text { Prfessor of NR \& Envir. } \\
\text { Management }\end{array}$ & pchandle@bsu.edu & $765-285-5780$ & 2000 W. University Ave & Muncie & IN & 47306 \\
\hline Butler University & Craig & Barnhart & Manager-Environmental Programs & cbarnhar@butler.edu & $317-940-6408$ & 4600 Sunset Ave. & Indianapolis & IN & 46208 \\
\hline $\begin{array}{l}\text { Department of Energy, Office of Environmental } \\
\text { Management }\end{array}$ & & & & The.Secretary@hq.doe.gov & 202-586-5000 & 1000 Independence Ave. & Washingtone & DC & 20585 \\
\hline U.S. Environmental Protection Agency & Lisa & Jackson & Administrator & & 202-272-0167 & 1200 Pennsylvania Ave & Washington & DC & 20004 \\
\hline U.S. Department of Agriculture & Tom & Vilsack & Secretary of Agriculture & & 202-720-2791 & 1400 Independence Ave., S.W. & Washington & DC & 20250 \\
\hline U.S. Department of the Interior & Ken & Salazar & Sectretary of the US Dept of Interior & feedback@ios.doi.gov & $202-208-3100$ & 1849 C Street NW & Washington & DC & 20240 \\
\hline U.S. Fish and Wildlife Service & Dan & Ashe & Deput Director & & & 1849 C Street NW & Washington & $\mathrm{DC}$ & 20240 \\
\hline Natural Resource Conservation Service & Matt & Harrington & $\begin{array}{l}\text { National Environmental } \\
\text { Coordinator }\end{array}$ & $\begin{array}{l}\text { matt.harrington@wdc.usda.g } \\
\text { ov }\end{array}$ & $202-720-4925$ & 14th and Independence Ave. & Washington & DC & 20250 \\
\hline Illinois Environmental Protection Agency & Dennis & McMurray & Public Ralations & $\begin{array}{l}\text { Dennis.McMurray@illinois.go } \\
v\end{array}$ & 217-785-1871 & 1021 North Grand Avenue East & Springfield & IL & 62794 \\
\hline $\begin{array}{l}\text { Indiana Department of Environmental } \\
\text { Management }\end{array}$ & Pigott & Bruno & $\begin{array}{l}\text { Commissioner of Office of Water } \\
\text { Quality }\end{array}$ & & $317-232-8603$ & $100 \mathrm{~N}$. Senate Ave. & Indianapolis & IN & 46204 \\
\hline $\begin{array}{l}\text { Florida Department of Environmental } \\
\text { Protection }\end{array}$ & Eric & Shaw & Environmental Manager & eric.shaw@dep.state.fl.us & $850-245-8429$ & 3900 Commonwealth Boulevard & Tallahassee & FL & 32399 \\
\hline Minnesota Pollution Control Agency & Jennifer & Maleitzke & & & $651-757-2549$ & 520 Lafayette Road & St. Paul & MN & 55155 \\
\hline Minnesota Department of Natural Resources & & & & & 651-296-6157 & 500 Lafayette Road & St. Paul & MN & 55155 \\
\hline Illinois Department of Natural Resources & Gary & Clark & Director & & 217-785-3334 & $\begin{array}{l}\text { One Natural Resources Way, } \\
\text { 2nd Floor }\end{array}$ & Springfield & IL & 62702 \\
\hline Indiana Department of Natural Resources & & & & & $317-232-4200$ & $\begin{array}{l}402 \text { West Washington St; Room } \\
\text { W }\end{array}$ & Indianapolis & IN & 46204 \\
\hline $\begin{array}{l}\text { Florida Fish and Wildlife Consercation } \\
\text { Commission }\end{array}$ & Nancy & Linehan & & & 850-488-4676 & 620 S. Meridian St. & Tallahassee & $\mathrm{FL}$ & 32399 \\
\hline Minnesota Office of Energy Security & & & & & 651-296-4026 & 87 7th Place East, Suite 500 & St. Paul & MN & 55101 \\
\hline Federal Emergency Management Agency & & & & & $202-646-2500$ & 500 C Street S.W. & Washington & DC & 20472 \\
\hline Chicago Metroplitan Agency for Planning & Randall & Blankenhorn & Executive Director & $\begin{array}{l}\text { Rblankenhorn@cmap.illinois.g } \\
\text { ov }\end{array}$ & $312-386-8600$ & $\begin{array}{l}233 \text { South Wacker } \\
\text { Suite } 800\end{array}$ & Chicago & IL & 60606 \\
\hline $\begin{array}{l}\text { South Central Illinois Regional Planning \& } \\
\text { Development Commission }\end{array}$ & Jeffrey & Beckman & Chairman & & 618-548-4234 & 120 South Delmar Ave; Suite A & Salem & IL & 62881 \\
\hline North Central Illinois Council of Governments & Nora & Fesco-Ballerine & Executive Director & norafb@ncicg.org & 815-875-3396 & 110 North Main Street & Princeton & IL & 61356 \\
\hline North West Municipal Conference & Mark & Fowler & Executive Director & & $847-296-9200$ & 1616 East Golf Road & Des Plaines & IL & 60016 \\
\hline $\begin{array}{l}\text { South Eastern Illinois Regional Planning and } \\
\text { Development Commission }\end{array}$ & Julie & Patera & Executive Director & $\begin{array}{l}\text { jpatera.sirpdc@clearwave.co } \\
\text { m }\end{array}$ & $618-252-7463$ & 230 West Poplar Street & Harrisburg & IL & 62946 \\
\hline Tri-County Regional Planning Commission & Terry & Kohlbuss & Executive Director & tkohlbuss@tricountyrpc.org & 309-673-9330 & 211 Fulton Street, Suite 207 & Peoria & IL & 61602 \\
\hline Madison County Council of Governments & Jerrold & Bridges & Executive Director & jbridges@mccog.net & 765-641-9482 & 16 East 9th Street, Room 100 & Anderson & IN & 46016 \\
\hline Michiana Area Council of Governments & Sandra & Seanor & Executive Director & macogdir@macog.com & $574-674-8894$ & 227 Wet Jefferson Blvd & South Bend & IN & 46601 \\
\hline $\begin{array}{l}\text { Northwestern Indiana Regional Planning } \\
\text { Commission }\end{array}$ & john & Swanson & Executive Director & jswanson@nirpc.org & $219-763-6060$ & 6100 Southport Road & Portage & IN & 46369 \\
\hline Arrowhead Regional Development Commission & Andy & Hubley & Regional Planning & Ahubley@ardc.org & $218-529-7521$ & 221 West First Street & Duluth & $\mathrm{MN}$ & 55802 \\
\hline Fargo-Moorhead Metropolitan Council of & Wade & Kline & Executive Director & kline@fmmetrocog.org & $701-232-3242$ & One Second Street North & Fargo & ND & 58102 \\
\hline
\end{tabular}




\begin{tabular}{|c|c|c|c|c|c|c|c|c|c|}
\hline Company & First Name & Last Name & Job Title & E-mail Address & Business Phone & Address & City & State/Prov & Zip Code \\
\hline \multicolumn{10}{|l|}{ Governments } \\
\hline Metropolitan Council & Christopher & Elvrum & Water Supply & $\begin{array}{l}\text { christopher.elvrum@metc.sta } \\
\text { te.mn.us }\end{array}$ & 651-602-1464 & 390 Robert St. North & St. Paul & $\mathrm{MN}$ & 55101 \\
\hline $\begin{array}{l}\text { The Space Coast Transportation Planning } \\
\text { Organization }\end{array}$ & Laura & Carter & & tpostaff@spacecoasttpo.com & $321-690-6890$ & $\begin{array}{l}2725 \text { Judge Fran Jamieson Way; } \\
\text { Bldg. B, Room 105, MS82 }\end{array}$ & Viera & $\mathrm{FL}$ & 32940 \\
\hline Central Florida Regional Planning Council & Alan & Klose & Senior Planner-Water Supply & & 863-534-7130 & 555 East Church Street & Bartow & FL & 33830 \\
\hline $\begin{array}{l}\text { Charlotte County-Punta Gorda Metropolitan } \\
\text { Planning Organization }\end{array}$ & & & & & $941-883-3535$ & $\begin{array}{l}25550 \text { Harbor View Road; Suite } \\
4\end{array}$ & $\begin{array}{l}\text { Port } \\
\text { Charlotte }\end{array}$ & $\mathrm{FL}$ & 33980 \\
\hline East Central Florida Regional Planning Council & Phil & Laurien & Executive Director & plaurien@ecfrpc.org & $407-262-7772$ & $\begin{array}{l}309 \text { Cranes Roose Blvd., Suite } \\
2000\end{array}$ & $\begin{array}{l}\text { Altamonte } \\
\text { Springs }\end{array}$ & $\mathrm{FL}$ & 32701 \\
\hline $\begin{array}{l}\text { North Florida Transportation Planning } \\
\text { Organization }\end{array}$ & Denise & Bunnewith & Executive Director & $\begin{array}{l}\text { dbunnewith@northfloridatpo. } \\
\text { com }\end{array}$ & $904-306-7510$ & 1022 Prudential Drive & Jacksonville & $\mathrm{FL}$ & 32207 \\
\hline $\begin{array}{l}\text { Florida Metropolitan Planning Organization } \\
\text { Advisory Council }\end{array}$ & Howard & Glassman & Executive Director & $\begin{array}{l}\text { howard.glassman@dot.state.f } \\
\text { l.us }\end{array}$ & $850-414-4062$ & 605 Suwannee St. & Tallahassee & $\mathrm{FL}$ & 32399 \\
\hline $\begin{array}{l}\text { Hillsborough Metropolitan Planning } \\
\text { Organization }\end{array}$ & Ramond & Chiaramonte & Executive Director & rayc@plancom.org & $813-272-5940$ & 601 E. Kennedy Boulevard & Tampa & $\mathrm{FL}$ & 33601 \\
\hline Metroplan Orlando & & & & info@metroplanorlando.com & $407-481-5672$ & $\begin{array}{l}315 \text { East Robinson Street, Suite } \\
355\end{array}$ & Orlando & $\mathrm{FL}$ & 32801 \\
\hline $\begin{array}{l}\text { Metropolitan Planning Organization for the } \\
\text { Miami Urbanized Area }\end{array}$ & Jose & Mesa & Director & jlm1@miamidade.gov & $305-375-4507$ & 111 NW 1 Street & Miami & $\mathrm{FL}$ & 33128 \\
\hline North Central Florida Regional Planning Council & Scott & Koons & Executive Director & koons@ncfrpc.org & $352-955-2200$ & 2009 NW 67th Place & Gainesville & $\mathrm{FL}$ & 32653 \\
\hline North East Florida Regional Planning Council & Brian & Teeple & Chief Executive Officer & bteeple@nefrc.org & $904-279-0880$ & 6850 Belfort Oakds Place & Jacksonville & $\mathrm{FL}$ & 32216 \\
\hline $\begin{array}{l}\text { Palm Beach County Metropolitan Planning } \\
\text { Organization }\end{array}$ & & & & mpopbc@pbcgov.org & $561-684-4170$ & 2300 North Jog Road, 4th Floor & $\begin{array}{l}\text { West Palm } \\
\text { Beach }\end{array}$ & $\mathrm{FL}$ & 33401 \\
\hline \multicolumn{10}{|l|}{ South Florida Regional Planning Council } \\
\hline Tampa Bay Regional Planning Council & Manny & Pumariega & Executive Director & manny@tbrpc.org & $727-570-5118$ & $\begin{array}{l}4000 \text { Gateway Centre Blvd., } \\
\text { Suite } 100\end{array}$ & Pinellas Park & FL & 33782 \\
\hline West Florida Regional Planning Council & Terry & Joseph & Executive Director & & 850-332-7976 & PO Box 11399 & Pensacola & FL & 32520 \\
\hline Withlacoochee Regional Planning Council & Michael & Moehlman & Executive Director & bday@wrpc.cc & $352-732-1315$ & 1241 SW 10th Street & Ocala & $\mathrm{FL}$ & 34471 \\
\hline Florida State Parks & & & & & $850-245-2157$ & 3900 Commonwealth Boulevard & Tallahassee & $\mathrm{FL}$ & \\
\hline Illinois Development Council & Michael & Lane & Executive Director & $\begin{array}{l}\text { mike@ildevelopmentcouncil.o } \\
\mathrm{rg}\end{array}$ & $217-528-5230$ & 225 E. Cook St. & Springfield & IL & 62704 \\
\hline $\begin{array}{l}\text { Economic Development Council for Central } \\
\text { Illinois }\end{array}$ & Sally & Hanley & Economic Development Director & shanley@edc.h-p.org & $309-495-5953$ & 100 SW Water Street & Peoria & IL & 61602 \\
\hline $\begin{array}{l}\text { Illinois Department of Commerce and } \\
\text { Economic Opportunity }\end{array}$ & Jonathan & Feipel & & & $800-785-6055$ & 620 East Adams St. & Springfield & IL & 62701 \\
\hline Florida Economic Development Council & Amy & Evancho & President/CEO & aevancho@fedc.net & 850-201-3330 & $\begin{array}{l}325 \text { John Knox Rd, Atrium } \\
\text { Building, Suite } 201\end{array}$ & Tallahassee & $\mathrm{FL}$ & 32315 \\
\hline Indiana Economic Development Corporation & Ryan & Asberry & Assistant Vice President & rasberry@iedc.IN.gov & $317-232-8962$ & One North Capitol, Suite 700 & Indianapolis & IN & 46204 \\
\hline $\begin{array}{l}\text { Minnesota Department of Employment and } \\
\text { Economic Development }\end{array}$ & & & & & $651-259-7114$ & 332 Minnesota St. & Saint Paul & $\mathrm{MN}$ & 55101 \\
\hline Great Lakes Protection Fund & David & Rankin & Program Director & & $847-425-8150$ & 1560 Sherman Ave & Evanston & IL & 60201 \\
\hline Alliance for the Great Lakes & Ed & Glatfelter & $\begin{array}{l}\text { Director, Water Conservation } \\
\text { Program }\end{array}$ & eglatfelter@greatlakes.org & $312-939-0838$ & & Chicago & IL & 60602 \\
\hline google & & & & & $650-253-0000$ & 1600 Amphitheatre Parkway & $\begin{array}{l}\text { Mountain } \\
\text { View }\end{array}$ & CA & 94043 \\
\hline Chicago Metropolitan Agency for Planning & Randall & Blankenhorn & Executive Director & $\begin{array}{l}\text { RBlankenhorn@cmap.illinois.g } \\
\text { ov }\end{array}$ & $312-386-8600$ & $\begin{array}{l}233 \text { South Wacker } \\
\text { Suite } 800\end{array}$ & Chicago & IL & 60606 \\
\hline Western Illinois University & Charles & Darnell & Director, Physical Plan & CG-Darnell@wiu.edu & 309-298-1834 & 1 University Circle & Macomb & IL & 61455 \\
\hline Univerity of Illinois at Chicago & Martin & Jaffe & Associate Professor & mjaffe@uic.edu & (312) 996-2178 & & & & \\
\hline University of North Carolina & Michael & Aitken & Professor and Chair & mike_aitken@unc.edu & (919) 966-1024 & University of North Carolina & Chapel Hill & NC & $\begin{array}{l}27599- \\
743\end{array}$ \\
\hline University of Illinois at Chicago & Moira & Zellner & Assistant Professor & mzellner@uic.edu & $312-996-2149$ & & & & \\
\hline
\end{tabular}




\begin{tabular}{|c|c|c|c|c|c|c|c|c|c|}
\hline Company & First Name & Last Name & Job Title & E-mail Address & Business Phone & Address & City & State/Prov & Zip Code \\
\hline University of Minnesota & Nathan & Johnson & Assistant Professor & nwjohnso@d.umn.edu & (218) 726-8063 & $\begin{array}{l}233 \text { Engineering Building } \\
1303 \text { Ordean Court }\end{array}$ & Duluth & MN & 55812 \\
\hline University of Minnesota Duluth & Patrick & Brezonik & Professor & brezonik@umn.edu & $612-625-0866$ & 10 Univeristy Dr. & Dulth & MN & 55812 \\
\hline US Army Corp of Engineers & Van & Antwerp & Comanding General & $\begin{array}{l}\text { hq- } \\
\text { publicaffairs@usace.army.mil }\end{array}$ & 202-761-0011 & 441 G. Street, NW & Washington & DC & 20314 \\
\hline \multicolumn{10}{|l|}{ NRG Energy } \\
\hline Avant Energy & Joseph & Fulliero & Vice President of Operations & $\begin{array}{l}\text { Joe.Fulliero@avantenergy.co } \\
\text { m. }\end{array}$ & $612-252-6514$ & $\begin{array}{l}200 \text { South Sixth Street } \\
\text { Suite } 300\end{array}$ & Minneapolis & MN & 55402 \\
\hline Minnesota Municipal Power Agency (MMPA) & Bob & Burchfield & Plant Manager & & $\begin{array}{l}507-331-4791 \\
\times 204\end{array}$ & $\begin{array}{l}200 \text { S. 6th St. } \\
\text { Suite } 300\end{array}$ & Minneapolis & MN & 55402 \\
\hline The Nature Conservancy - Indiana Field Office & John & Shuey & Director of Conservation Science & jshuey@tnc.org & 317-951-8818 & $\begin{array}{l}1505 \text { N. Delaware Street } \\
\text { Suite } 200\end{array}$ & Indianapolis & IN & 46202 \\
\hline The Nature Conservancy & Paul & Labus & Program Director & plabus@tnc.org & $219-473-4312$ & 2400 New York Avenue & Whiting & IN & 46394 \\
\hline Nisource Distribution Operations & Brian & Kortum & Leader - Survey \& Land & bkortum@nisource.com & $219-662-4212$ & 801 East 86 th Avenue & Merrillville & IN & 46410 \\
\hline Nisource & Dan & Plath & Water Program Leader & dkplath@nisource.com & $219-647-5268$ & & & & \\
\hline Department of Energy, NETL & Barbara & Carney & Project Manager & barbara.carney@netl.doe.gov & 304-285-4671 & $\begin{array}{l}3610 \text { Collins Ferry Road } \\
\text { P.O. Box } 880\end{array}$ & Morgantown & wV & $\begin{array}{l}26507- \\
0880\end{array}$ \\
\hline Sterling Energy Services & Ken & Duvall & President & kduvall@sterlingenergy.com & 770-381-1995 & $\begin{array}{l}2215 \text { Perimeter Park Drive } \\
\text { Suite } 8\end{array}$ & Atlanta & GA & 30341 \\
\hline Florida Power \& Light Co & Robert & Regan & Manager - Project Development & robert_regan@FPL.com & $561-304-5402$ & 700 Universe Boulevard EX1/JB & Juno Beach & $\mathrm{FL}$ & $\begin{array}{l}33408- \\
0420\end{array}$ \\
\hline Florida Power \& Light Co & Andrew & Fiajole & Environmental Specialist & Andy.Fiajole@FPL.com & $561-691-2766$ & 700 Universe Boulevard & Juno Beach & $\mathrm{FL}$ & 33408 \\
\hline Florida Power \& Light Co & James & Lindsay & $\begin{array}{l}\text { Principal Biologist - Environmental } \\
\text { Services }\end{array}$ & jim_lindsay@FPL.com & 561-691-7032 & 700 Universe Boulevard JES/JB & Juno Beach & $\mathrm{FL}$ & 33408 \\
\hline Florida Power \& Light Co & Barbara & Linkiewicz & Director - Environmental Licensing & barbara.p.linkiewicz@FPL.com & $561-691-7518$ & 700 Universe Boulevard JES/JB & Juno Beach & FL & 33408 \\
\hline Florida Power \& Light Co & Matthew & Raffenberg & Manager - Environmental Licensing & $\begin{array}{l}\text { matthew_raffenberg@FPL.co } \\
\text { m }\end{array}$ & $561-691-2808$ & 700 Universe Boulevard JES/JB & Juno Beach & $\mathrm{FL}$ & 33408 \\
\hline Progress Energy Florida, Inc. & William & Luke & $\begin{array}{l}\text { O \& R Superintendent - Hines } \\
\text { Energy Complex }\end{array}$ & william.luke@pgnmail.com & 863-519-6125 & $\begin{array}{l}7700 \text { County Road } 555 \\
\text { HE-44 }\end{array}$ & Bartow & $\mathrm{FL}$ & 33830 \\
\hline Progress Energy Florida, Inc. & Doug & Yowell & $\begin{array}{l}\text { Sr. Environmental Specialist - Env. } \\
\text { Services Sect. }\end{array}$ & doug.yowell@pgnmail.com & $727-820-5228$ & $\begin{array}{l}299 \text { 1st Ave. North } \\
\text { PEF-093 }\end{array}$ & $\begin{array}{l}\text { St. } \\
\text { Petersburg }\end{array}$ & $\mathrm{FL}$ & 33701 \\
\hline Progress Energy Florida, Inc. & Martin & Drango, P.E. & $\begin{array}{l}\text { Plant Manager - Hines Energy - } \\
\text { Tiger Bay Complex }\end{array}$ & martin.drango@pgnmail.com & 863-519-6103 & $\begin{array}{l}7700 \text { County Road } 555 \\
\text { HE-44 }\end{array}$ & Bartow & $\mathrm{FL}$ & 33830 \\
\hline
\end{tabular}

